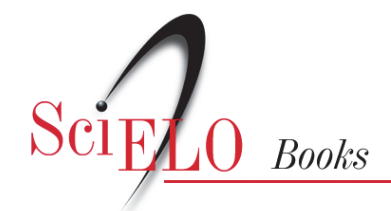

\title{
Filosofia, história e sociologia das ciências I:
}

abordagens contemporâneas

\section{Vera Portocarrero}

org.

PORTOCARRERO, V., org. Filosofia, história e sociologia das ciências I: abordagens contemporâneas [online]. Rio de Janeiro: Editora FIOCRUZ, 1994. 272 p. ISBN: 85-85676-02-7. Available from SciELO Books $<$ http://books.scielo.org $>$.

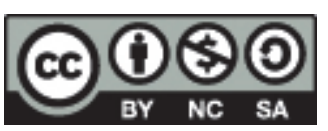

All the contents of this work, except where otherwise noted, is licensed under a Creative Commons Attribution-Non Commercial-ShareAlike 3.0 Unported.

Todo o conteúdo deste trabalho, exceto quando houver ressalva, é publicado sob a licença Creative Commons Atribuição Uso Não Comercial - Partilha nos Mesmos Termos 3.0 Não adaptada.

Todo el contenido de esta obra, excepto donde se indique lo contrario, está bajo licencia de la licencia Creative Commons Reconocimento-NoComercial-CompartirIgual 3.0 Unported. 


\section{FILOSOFIA, \\ HISTÓRIA E SOCIOLOGIA DAS CIÊNCIAS I:}

Abordagens Contemporâneas 


\section{FUNDAÇÃO OSWALDO CRUZ}

Presidente

Paulo Marchiori Buss

Vice-Presidente de Desenvolvimento Institucional, Informação e Comunicação

Paulo Gadelha

\section{EDITORA FIOCRUZ}

Coordenador

Paulo Gadelha

Conselho Editorial

Carlos E. A. Coimbra Jr.

Carolina M. Bori

Charles Pessanha

Jaime L. Benchimol

José da Rocha Carvalheiro

José Rodrigues Coura

Luis David Castiel

Luiz Fernando Ferreira

Maria Cecília de Souza Minayo

Miriam Struchiner

Paulo Amarante

Vanize Macêdo

Coordenador Executivo

João Carlos Canossa P. Mendes 


\title{
FILOSOFIA, HISTÓRIA E SOCIOLOGIA DAS CIÊNCIAS I:
}

\section{Abordagens Contemporâneas}

\author{
VERA PORTOCARRERO
}

(Organizadora)

Segunda reimpressão

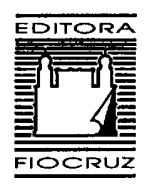


Copyright (C) 1994 dos autores

Todos os direitos desta edição reservados à

Fundação Oswaldo Cruz / Editora

ISBN: 85-85676-02-7

1a Edição: 1994

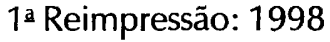

2 Reimpressão: 2002

Projeto Gráfico e Capa: Ruben Fernandes Ilustração da Capa: Chico Comes Carneiro

Revisão: Marcionilio Cavalcante de Paiva

Supenvisão Editorial: Walter Duarte

Revisão $1^{\text {a }}$ Reimpressão: Fernanda Veneu

Editoração Eletrônica 1 a Reimpressão: Guilherme Ashton

Catalogação-na-fonte

Centro de Informação Científica e Tecnológica

Biblioteca Lincoln de Freitas Filho

P8535 Portocarrero, Vera (Org.)

Filosofia, história e sociologia das ciências I: abordagens contemporâneas/Organizado por Vera Portocarrero. - Rio de Janeiro: Editora FIOCRUZ, 1994.

$272 p$.

1. Ciência- História. 2. Filosofia. 3. Sociologia. 4. Pesquisadores. 5. Conhecimento. I. Título.

CDD - 20.ed. -500

2002

EDITORA FIOCRUZ

Av. Brasil, $4036-1^{2}$ andar - sala 112 - Manguinhos

21040-361 - Rio de Janeiro - RJ

Tels: (21) 3882-9039 e 3882-9041

Telefax: (21) 3882-9007

http://www.fiocruz.br

e-mail: editora@fiocruz.br

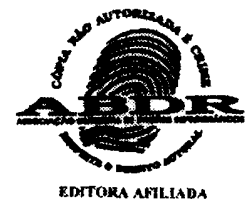




\section{AGRADECIMENTOS}

Agradecemos a todos aqueles que, de diferentes maneiras, contribuíram para a realização deste trabalho. Em especial: Tania Fernandes, Chefe do Departamento de Pesquisa da Casa de Oswaldo Cruz/FIOCRUz; Maria Rachel Fróes e Marcos Chor Maio, pesquisadores da COC/FIOCRUZ; Elaine Kabarite, estagiária; Chico Gomes Carneiro, artista plástico. Agradecemos, sobretudo, a todos os coautores, sem cuja participação esta obra seria impossível. 


\section{PREFÁCIO}

A dinâmica e as possíveis interações das ciências, da filosofia em geral, da episimportantes temas do debate intelectual contemporâneo. A imagem de um tetraedro proposta recentemente pelo filósofo francês Michel Paty é uma das possibilidades de expressá-las, acentuando que cada uma daquelas áreas de conhecimento, representada pelos vértices do tetraedro, se relaciona e se enriquece no contato com as outras, mas sempre de maneira peculiar e assimétrica. $\mathrm{O}$ tetraedro, eclético, preserva os espaços de cada disciplina e ressalta a riqueza de sua combinatória.

É indiscutível a vitalidade dessas interações, mesmo quando prevalece a radicalidade de alguns autores e suas intenções de hegemonia. Podemos citar, como exemplo, a crítica ao neopositivismo e à filosofia analítica, já expressiva nos anos 20. Entre outras polêmicas presentes naquele contexto, destaca-se aquela que, ao opor "internalistas" e "externalistas", possibilitou um frutífero encontro de filósofos, cientistas, sociólogos e antropólogos com desdobramentos até nossos dias.

A representação de uma ação sinérgica e relativamente harmônica em um campo de diversidades traduz, por sua vez, a complexidade dos fenômenos estudados e remete à disputa entre disciplinas e abordagens que resultam em sucessivos deslocamentos na filosofia do conhecimento, na epistemologia, na sociologia e na etnociência.

Nossos tempos demonstram, ainda, expressiva contribuição das ciências sociais a partir da década de 60 , quando, com destaque para a obra de Thomas Kuhn, se evidenciou a ruptura com a visão da ciência como sistema autônomo de produção de verdades. Entre outras contribuições que sucederam a de Kuhn, destacam-se as postulações do Programa Forte, a análise de controvérsias, o desenvolvimento das abordagens antropológicas e os estudos que propõem apreender em uma mesma dinâmica o universo dos artefatos e dos homens. Autores como David Bloor, Harry Collins, Steve Woolgar, Callon, Bruno Latour, Shapin e Schaffer são destaques desse processo, a maioria deles de introdução recente em nossos cursos de pós-graduação e pouco conhecidos pela academia.

Este é o fruto do trabalho de filósofos, historiadores e cientistas sociais que se debruçaram sobre a obra de autores clássicos, assim como a de representantes de abordagens recentes e inovadoras sobre o tema. Esta escolha permite uma rara visão de conjunto em que o tetraedro idealizado por Paty parece materializar-se.

Não se pretende uma apresentação exaustiva das diferentes abordagens, nem uma resenha sistemática do conjunto da obra dos autores selecionados, 
mas sim um exercício instigante de leituras originais e tematização de questōes que certamente suscitarão novos debates. Os autores realizam uma dupla tarefa de divulgação e produção de conhecimento, sem dúvida, a melhor demonstração da vitalidade que se anuncia para esta área.

O lançamento de Filosofia, História è Sociologia das Ciências l: abordagens contemporâneas traz, portanto, múltiplos significados. Representa, entre outros indicadores, o crescimento e a profissionalização da área de história das ciências em nosso país, que acompanha, ainda à distância, seu impressionante desenvolvimento em âmbito internacional.

Ao comentar os resultados do Congresso Internacional de História da Ciência, realizado em 1968, em Paris, Mirko Grmek ciestacava duas diferenças marcantes em relação ao primeiro encontro desse gênero, também na capital francesa, em 1929: a explosão demográfica - de 40 pessoas e 10 países para 800 pessoas e 40 países - e, mais importante, a grande diversidade do temário, aberto a todas as ciências e abordagens. No ano passado (1993), em Zaragoza, o XIX Congresso Internacional de História da Ciência refletiu a consolidação dessa tendência, chegando a inquietar pelo seu gigantismo: inúmeros participantes de todos os cantos do mundo envolvidos em uma estonteante diversidade de temas.

Em nosso país, os sinais finalmente começam a ser animadores. Há um crescente interesse que se reflete na maior participação nos seminário da Sociedade Brasileira de História da Ciência, no aumento de publicações, inclusive de novos periódicos, a exemplo do lançamento recente de História, Ciências, Saúde - Manguinhos, e na inclusão de temas de história das ciências em cursos de pós-graduação.

Filosofia, História e Sociologia das Ciências I: abordagens contemporâneas é fruto, também, de diretrizes institucionais. É significativo que este livro tenha sido escolhido para integrar o lançamento da Editora da Fundação Oswaldo Cruz. A FIOCRUZ elegeu a reflexão abrangente sobre as ciências como uma prioridade que se tem traduzido em diversas iniciativas de suas unidades técnico-científicas. Há uma clara consciência na intuição sobre a necessidade dessa reflexão não apenas para as atividades acadêmicas, mas para a própria compreensão do sentido de seu projeto e inserção social.

Por meio da Casa de Oswaldo Cruz, esse esforço tem se concentrado no campo da história das ciências em todas as dimensões indispensáveis para a consolidação de uma área de estudos: a pesquisa, o ensino e a circulação de idéias por seminários e publicações que nos permitem, hoje, reunir pesquisadores de diferentes instituições do Brasil e do exterior para a conclusão de uma obra de tal porte. Estão aqui concretizadas experiências adquiridas e cursos de pós-graduação do Instituto Universitário de Pesquisas do Rio de Janeiro, em cooperação com os Institutos de Filosofia e Ciências Humanas da Universidade Federal do Rio de Janeiro e de Ciências Humanas da Universidade Federal do Rio Grande do Sul, em trocas acadêmicas durante os seminários da Sociedade Brasileira de 
História da Ciência e da Tecnologia e no convívio com os pesquisadores da Unidade 158 - Savoir et Pratiques dans le Champ Médicale: Histoire, Sociologie, Psychanalise - do Institut Nationale de Recherche Médicale (INSERM), que mantém um acordo de cooperação com a Casa de Oswaldo Cruz. Ao refletir sobre estas experiências, estamos certos de que Filosofia, História e Sociologia das Ciências I: abordagens contemporâneas é uma obra madura e equilibrada, que se tornará referência obrigatória para cursos de graduação e pós-graduação, além de se destinar a um público qualificado, cada vez mais interessado em entender as grandes linhas que orientam o debate acadêmico sobre a história das ciências.

Como o título indica, este projeto prevê o lançamento de um novo número, dedicado à apresentação de estudos de casos. O futuro direcionamento para temas da área biomédica, que reflete a inserção institucional da Casa de Oswaldo Cruz, levará em conta a necessidade de pensar o campo da história das ciências como um todo. Basta lembrarmos a relevância dos trabalhos de Fleck, Canguilhem, Foucault, Kuhn ou a riqueza de produções recentes de François Delaporte, Ilana Löwy, Anne Maria Moulin e Bruno Latour, entre outros. Ao focalizarem temas da área de saúde, contribuem teórica e metodologicamente para os estudos sobre as ciências em geral. A reflexão sobre a ciência biomédica e a saúde pública, por força de seu objeto, tradicionalmente polarizado entre o ideal da ciência pura e as demandas de uma prática social, tem sido um constante estímulo para questionar as abordagens reducionistas.

Finalmente, gostaríamos de destacar que, se o projeto incorpora tantas marcas institucionais, é, sobretudo, a tradução da competência acadêmica, da dedicação e da arte de congregar esforços de Verà Portocarrero, a quem expressamos todo o nosso reconhecimento.

Paulo Gadelha

Diretor da Casa de Oswaldo Cruz 


\section{COLABORADORES}

\section{FRANÇOIS DELAPORTE}

Professor de Filosofia da Universidade de Picardie.

\section{VERA PORTOCARRERO}

Professora de Filosofia da Universidade do Estado do Rio de Janeiro.

\section{NARA BRITTO}

Pesquisadora da Casa de Oswaldo Cruz/Fundação Oswaldo Cruz.

\section{MANUEL PALÁCIOS}

Professor de Sociologia da Universidade Federal de Juiz de Fora. Pesquisador do Instituto

Universitário de Pesquisa do Rio de Janeiro.

\section{GILBERTO HOCHMAN}

Pesquisador da Casa de Oswaldo Cruz/Fundação Oswaldo Cruz.

\section{ALBERTO OLIVA}

Professor de Filosofia da Universidade Federal do Rio de Janeiro. Pesquisador do Conselho Nacional de Desenvolvimento Científico e Tecnológico.

\section{ANNA CAROLINA KREBS PEREIRA REGNER}

Professora de Filosofia da Universidade Federal do Rio Grande do Sul.

\section{LUIZ OTÁVIO FERREIRA}

Pesquisador da Casa de Oswaldo Cruz/Fundação Oswaldo Cruz. Professor de Sociologia da Universidade do Estado do Rio de Janeiro.

NÍSIA TRINDADE LIMA

Pesquisadora da Casa de Oswaldo Cruz/Fundação Oswaldo Cruz. Professora de Sociologia da Universidade do Estado do Rio de Janeiro.

\section{ILANA LÖWY}

Pesquisadora e Professora de História da Ciência do Institut Nacional de la Santé et de la Recherche Médicale. 


\section{SUMÁRIO}

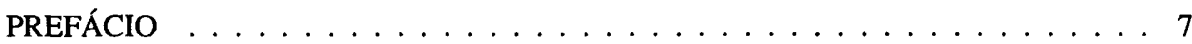

Paulo Gadelha

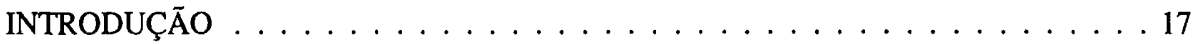

Vera Portocarrero

CAPÍTULO I . . . . . . . . . . . . . . . . . . . . . . 23

A HISTÓRIA DAS CIÊNCIAS SEGUNDO G. GANGUILHEM

François Delaporte

CAPÍTULO 2 43

FOUCAULT: A HISTÓRIA DOS SABERES E DAS PRÁTICAS

Vera Portocarrero

1. Uma História de Verdade

1.1. A história arqueologica

1.2. A história genealógica

2. Uma Política da Verdade

2.1. Verdade e poder

2.2. O poder disciplinar e o biopoder

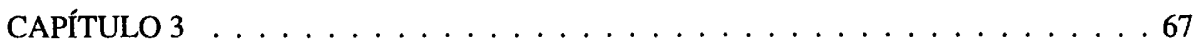
KUHN: O NORMAL E O REVOLUCIONÁRIO NA REPRODUÇÃO DA RACIONALIDADE CIENTÍFICA

Alberto Oliva

1. Kuhn e o Discurso Epistemológico Tradicional

2. Ciência: a pesquisa sob a batuta de um paradigma

3. A Ciência Normal e a Reprodução do Consenso

4. A Rota para a Crise

5. A Natureza do Discurso Científico: a irrupção do dissenso

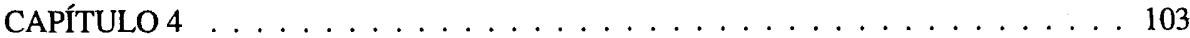
FEYERABEND/LAKATOS: "ADEUS À RAZÃO" OU CONSTRUÇÃO DE UMA NOVA RACIONALIDADE

Anna Carolina Krebs Pereira Regner

1. Alcance Epistemológico da História das Ciências: o questionamento da "racionalidade"

2. A Proposta "Racionalista" de Lakatos

3. A Crítica de Feyerabend ao "Nacionalismo"

4. "Adeus à Razão" ou "Princípios de Racionalidade radicalmente Diferentes"? 
OS INTELECTUAIS NO MUNDO E O MUNDO DOS INTELECTUAIS:

UMA LEITURA COMPARADA DE KARL MANNHEIM E PIERRE BOURDIEU

Luiz Otávio Ferreira e Nara Britto

1.É Possível uma Sociologia do Conhecimento?

2. Educação Escolar: desenraizamento ou autarquização do intelectual

CAPÍTULO 6

VALORES SOCIAIS E ATIVIDADES CIENTIFICAS: UM RETORNO À AGENDA DE ROBERT MERTON

Nisia Trindade Lima

1. Nota sobre a produção intelectual de Robert Merton e sua influência na sociologia da ciência

2. Intelligentsia e Validade do Conhecimento: a crítica a Mannheim

3. As Contribuições de Robert Merton à Sociologia da Ciência

4. Merton e o Debate Atual em Sociologia da Ciência

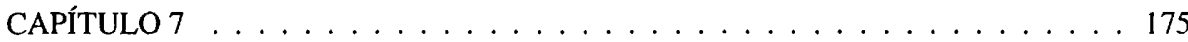

O PROGRAMA FORTE DA SOCIOLOGIA DO CONHECIMENTO E O PRINCÍPIO DA CAUSALIDADE

Manuel Palácios

1. O Programa Forte da Sociologia do Conhecimento e o Princípio da Causalidade

2. Modelo Causal e Modelo Teleológico

2.1. Princípios universais de racionalidade

2.2. A falácia da causalidade

2.3. A indeterminação das variáveis sociais

3. O Programa Forte e a Teoria dos Jogos de Linguagem de Wittgenstein

3.1. A teoria dos jogos de linguagem de Wittgenstein

3.2. Uso e significado

3.3. Jogos de linguagem e padrões de atividade

3.4. Finitismo

3.5. Aplicação conceitual: rotinização e inovação

4. Interesses e Conhecimento

4.1. Finitismo e instrumentalismo

4.2. Formas de vida e jogos de linguagem

CAPÍTULO 8 . . . . . . . . . . . . . . . . . . . . . . . . . . 199

A CIÊNCIA ENTRE A COMUNIDADE E O MERCADO: LEITURAS DE KUHN, BOURDIEU, LATOUR E KNORR-CETINA

Gilberto Hochman

1. Kuhn e a Comunidade Científica como Unidade Analítica

2. Bourdieu Procura a Comunidade Científica e Descobre o Mercado

3. Latour Vai ao Laboratório e Encontra o Ciclo de Credibilidade

4. Knorr-Cetina Vai ao Laboratório e Encontra a Arena Transepistêmica

5. Considerações Finais 
CAPÍTULO 9

FLECK E A HISTORIOGRAFIA RECENTE DA PESQUISA BIOMÉDICA

Ilana Löwy

1. Historiadores, Sociólogos e Laboratórios Biomédicos

2. Fleck e a Historiografia do Laboratório Biomédico nos Anos 30

3. Historiografia do Laboratório Biomédico Hoje: gênese, estabilização e difusão do conhecimento biomédico

3.1. Instrumentos, reagentes e padronização do conhecimento local aos "fatos científicos"

3.2. Laboratórios biomédicos, clínicas e indústria: formação mútua de métodos e fatos

4. "Objetos Fronteiriços", "Conotação", "Traduçōes" e "Zonas de Negociação": instrumentos de aferição para a historiografia da pesquisa biomédica

BIBLIOGRAFIA GERAL $\ldots \ldots \ldots \ldots \ldots \ldots \ldots \ldots \ldots \ldots \ldots$

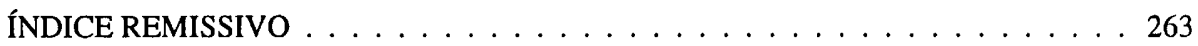




\section{INTRODUÇÃO}

\section{Panorama do Debate acerca das Ciências}

Vera Portocarrero (org.)

T

Temos assistido, nos últimos anos, a um debate sobre os diversos aspectos que constituem o que se compreende por ciência. Toma-se como ponto de partida a necessidade de repensar o otimismo çientificista, acirradó no século $X X$, com o positivismo, pelo ideal de unidade, objetividade, progresso e, sobretudo, pela noção de verdade científica como bem social. Supõe-se clara a meta de compreender a ciência, entender sua evolução, sondar suas origens, abordar suas crises, denunciar seu caráter de violência e de dominação da natureza e dos homens. Seu maior desafio agora não é dominar, mas salvaguardar o mundo.

A ciência é hoje uma questão que preocupa cientistas e intelectuais, apresentando-se-nos, talvez pela primeira vez, desde Galileu, não mais apenas como adjuvante do trabalho, da saúde e das luzes, mas como risco. Já não se discutem as revoluções científicas restringindo-as a seu caráter metodológico, como se os cientistas fossem os trabalhadores da prova stricto sensu, os trabalhadores meticulosos da boa consciência.

Considera-se a ciência uma das maiores fontes de patologia e mortalidade do mundo contemporâneo, sobretudo depois da Grande Guerra. Enfatiza-se sua constituição ética e social, seja para desmitificar sua pretensão à neutralidade, seja para apontar o perigo que representa e a responsabilidade política de que deve estar investida. A ciência é apresentada como uma importante forma de poder, sobretudo em sua relação com a alta tecnologia que hoje conhecemos.

Reivindica-se, cada vez mais, a superação de todas as dicotomias sobre as quais se funda o cientificismo, tais como conhecimento e política, ciência e sociedade, teoria e prática, razão e poder, sujeito e objeto. A epistemologia já não é o espaço exclusivo da análise da racionalidade e da linguagem, mas está inteiramente imiscuída com as questões científicas.

A noção de ato epistemológico não correponde mais necessária ou exclusivamente ao cogito cartesiano, pois a ciência é compreendida como produção 
técnica de objetos científicos construídos. Ela é, deste ponto de vista, construção de um objeto depurado cientificamente por um sujeito que é social, estabelecido através da comunicação e do controle.

Afastado da mística cientificista, tal enfoque tenta mostrar que, ao tomar a descrição do fenômeno como o próprio fenômeno, podemos determinar, ou melhor, alcançar pontos estáveis - "científicos" - a partir da transformação de fatos em artefatos, que funcionam na prática; rejeita-se, então, a oposição entre o fato objetivo e sua descrição científica.

Contra a perpetuação irrefletida de tais binômios, busca-se recuperar a criatividade num esforço inter, intra ou trans-disciplinar, rejeitando os procedimentos da repetição, cópia ou representação, uma vez que estes, fragmentários, perderam a possibilidade da totalidade ativa do saber.

Contra todo dogmatismo, impõe-se a pesquisa histórica das ciências. Tomase como ponto de partida a necessidade de analisar suas trajetórias, não se limitando mais ao plano das idéias. Um número significativo de historiadores, filósofos e sociólogos desenvolveu, nos últimos vinte anos, um interesse crescente pela ciência não só como teoria, mas como prática social, econômica e política e como fenômeno cultural, ultrapassando sua condição de sistema teórico-cognitivo.

Novas abordagens analisam ainda, para além destas, as práticas de laboratório, constituindo um corpus de observações sobre estas atividades a fim de integrar todos os aspectos do fazer ciência, com o objetivo de compreender sua complexidade, através da presença do trabalho empírico na revolução científica, considerada, no limite, revolução das mãos mais do que das idéias.

Este interesse deve-se à observação das práticas experimentais, que, na ciência moderna, localizam-se no laboratório. A nova história estuda as práticas locais e sua inserção social, relacionando-as com os instrumentos, os materiais, os conceitos e o saber, para afirmar sua multifuncionalidade.

Desde sua fundação no século XVI, a ciência moderna vem sendo objeto de investigação. Primeiramente, através das "teorias do conhecimento", em seguida, pela "filosofia da ciência", mais tarde pelas "epistemiologias lógicas" e "históricas", ou, mais contemporaneamente, pela "história da ciência", que reúne abordagens históricas, filosóficas e sociológicas.

As "teorias do conhecimento" pesquisam os processos de produção de conhecimento pelo sujeito cogonoscente, na tentativa de explicar a relação entre o sujeito que faz ciência, o objeto de conhecimento e o "desvelamento", a "representação" ou a "produção" da verdade científica; como o fez Descartes, por exemplo, numa perspectiva idealista e racionalista, na França; ou Hume e Locke, numa perspectiva realista e empirista, na Inglaterra; ou, mais tarde, Kant, ao buscar as condições de possibilidade do verdadeiro conhecimento, atribuindo-as às categorias a priori do sujeito transcendental. 
Nestes casos, discute-se a ciência questionando-a do ponto de vista destas oposições (racionalismo $x$ empirismo ou idealismo $x$ realismo), com o objetivo de determinar as faculdades do sujeito e sua capacidade de produzir representações suscetíveis de objetividade. Afirma-se que o conhecimento científico é produzido previamente na e pela razão, mesmo que tenha de recorrer à experiência empírica; ou que é produzido a partir do dado empírico, mesmo que, num segundo momento seja elaborada pela razão. De um extremo ao outro, gradientes foram estabelecidos, como por exemplo a noção de "racionalismo aplicado" de Bachelard.

$\mathrm{O}$ interesse por tais questões desenvolveu-se, por um lado, até nossos dias, numa perspectiva lógica, principalmente a partir da filosofia da linguagem, de Wittgenstein a Quine; ela visa ao estudo e à construção da linguagem científica, assim como à investigação sobre as regras lógicas necessárias ao enunciado científico correto.

Por outro lado, desde Comte, no século XIX, a questão ciência não mais se limita às análises dos processos cognitivos. Há um deslocamento para uma filosofia fundada na história da ciência e sua relação intrínseca com o progresso da sociedade e da humanidade. Em Curso de Filosofia Positiva, a ciência é compreendida como uma teoria que progride no sentido de uma unidade geral, para uma verdade finalmente positiva, sendo sua gênese racional e psicossociológica.

As análises das epistemologias lógicas fundadas na filosofia da linguagem foram retomadas pela sociologia do conhecimento, inspirando, nos anos 70, o chamado "Programa Forte de Sociologia". Com base na noção de construção lingüística como construção convencional, indissociável dos processos de interação social entre os indivíduos e de suas necessidades práticas, Bloor, Barnes e outros derivam a concepção de ciência desta noção de construção.

A perspectiva construtivista, que inclui não somente a noção de linguagem, método e objeto construídos, mas também a idéia de que a legitimação dos conhecimentos científicos se constrói social e historicamente, parece imporse cada vez mais no decorrer de nosso século.

A reflexão sobre a ciência dirigiu-se também para a vertente histórica, desenvolvida até hoje, através das epistemologias, surgidas na década de 30 , e de outras formas de história da ciência propostas nos últimos vinte anos.

Avessas ao dogmatismo unitário, metodológico e teleológico da análise comtiana, posicionam-se as epistemologias de caráter deliberadamente não-positivista, histórias críticas da ciência. Internalistas ou francesas, representadas por Bachelard, Koyré, e Canguilhem, atêm-se à análise da racionalidade científica; externalistas ou inglesas, representadas por Popper e Kuhn, restringem os estudos da ciência a explicações sociais, pressupondo que o caráter real da ciência situase para além de seu campo de investigação, isto é, o conteúdo. Entre um extremo e outro, encontraremos gradientes, cujo desafio é sintetizar os dois aspectos. 
Estas duas formas de pensar a ciência - internalista e externalista - implicam uma inviabilidade de diálogo, hoje considerada infrutífera. Pois, para a primeira, não será possível fazer história da ciência, sem se considerarem os elementos propriamente científicos; ao passo que para a externalista, o mais importante é a explicitação da produção científica em seus componentes sociais, sem o que o trabalho do historiador parecerá absurdo.

Deste modo, tanto em um caso como no outro, a ciência é analisada a partir de uma ruptura entre a comunidade e os conteúdos do conhecimento, de uma redução do social ao exterior das atividades cognitivas.

Para a "nova história das ciências", a distinção internalismo e externalismo - e todas as tentativas de sua síntese - são consideradas pouco produtivas e devem ser substituídas por uma reflexão sobre as condiçōes históricas da formação destas duas categorias - sua genealogia - com o objetivo de ultrapassar tal dicotomia.

Justamente a concepção e o valor de ciência são surpreendentemente plurais. Vão desde sua compreensão como um sistema de conhecimento puramente teórico e neutro até a idéia de ciência como prática política. À ciência atribui-se o valor de verdade objetiva, isenta de subjetividade e de interesses políticos - expressão máxima da razão positiva situada do lado do bem, das técnicas e dos remédios, continuamente salvadora - conforme ocorre tradicionalmente.

As tendências mais recentes desenvolvem a noção de ciência contextual, contingencial, circunstancial, resultante da combinação de fatores sociais e econômicos. As vertentes contemporâneas mais raciais conferem à ciência estatuto semeIhante a outras manifestações culturais como a religião e a arte, considerando-a uma prática mais humana e mais caótica do que se acreditava anteriormente.

À ciência pode-se, portanto, atribuir um valor de comprometimento político, enquanto considerada uma rede de relações de forças que não têm existência em si, a não ser como séries de fatores externos à sua constituição lógica, não implicando uma questão de racionalidade científica.

Entre estes extremos, encontramos as mais diversas formas de análise, dentre as quais devemos incluir aquelas que se pretendem não judicativas que se negam a discutir o valor de legitimidade ou veracidade dos juízos científicos, ou, ainda, seu valor ético ou social.

Em sentido mais corrente, podemos afirmar que se entende por ciência o conjunto das aquisições intelectuais das matemáticas e das disciplinas da investigação do dado natural e empírico (que podem ou não fazer uso das matemáticas, mas tendendo sempre à matematização). Freqüentemente este sentido é controvertido $\mathrm{e}$ rejeitado ou mesmo considerado irrelevante para a história da ciência.

Neste caso, ela consiste em conhecimento constituído por conceitos, juízos e raciocínios, obedecendo a regras lógicas de um conjunto ordenado de proposiçōes, para alcançar objetivamente a verdade dos fatos, através da verificação experimental da adaptação das idéias aos mesmos. 
Deste ponto de vista, os enunciados fáticos confirmados chamam-se dados empíricos e são obtidos em uma relação com a teoria, constituindo matériaprima da elaboração teórica. O conhecimento científico, então, transcende os fatos para produzir novos fatos e explicá-los. A investigação científica não se limita, portanto, aos fatos observados, mas os seleciona, controla e reproduz. A experiência é racionalizada através de teorias, hipóteses e conceitos.

Outra perspectiva de análise do conhecimento científico parte do pressuposto platônico que opõe epistemé e doxa, ciência ou conhecimento verdadeiro e opinião ou conhecimento de senso comum. Tradicionalmente, a ciência é considerada o lugar da verdade por se fundar no logos, na razão, especificada, a partir da ciência moderna, pela exigência de objetividade e experimentação. Neste sentido, estuda-se o modo como o conhecimento científico é alcançado pelo abandono total do conhecimento da opinião, conforme afirma Bachelard, ou por um processo de purificação, como explica Popper.

Contudo, a concepção mais corrente e tradicionalmente aceita nem sempre é considerada a melhor ou a mais correta. Ao contrário, ela parece um dos pontos mais afastados do atual debate sobre a ciência. 


\section{A História das Ciências segundo G. Canguilhem}

François Delaporte

Tradução de Gilda Gomes Carneiro Revisão técnica de Vera Portocarrero

Q

uando se evoca a corrente da epistemologia francesa, associam-se os nomes de Bachelard e de Canguilhem e recorda-se, quanto ao segundo, a filiação bachelardiana. A razão que funda tal aproximação e tal genealogia é a seguinte: Georges Canguilhem aplicou as categorias da epistemologia bachelardiana ao campo da história das ciências da vida. Aliás, sabe-se que Canguilhem não deixa jamais de lembrar a "lição" de Gaston Bachelard. É um fato: a história tal como a entende Canguilhem não é nem um pleonasmo da ciência, nem filha da memória, mas filha do juízo, isto é, história normativa. Eis o que basta para dar conta da semelhança dos dois projetos em suas grandes linhas.

Mas esta comunhão de pontos de vista não deveria atenuar a divergência dos métodos, nem mascarar a irredutível diferença dos objetos de estudo. $O$ fato de que Canguilhem tenha tomado de Bachelard alguns axiomas metodológicos não nos desobriga de examinar o sentido, a extensão e os limites destas apropriações. Descreveremos, aqui, a maneira pela qual Canguilhem fez valer, não sem modificações, estes princípios metodológicos no campo da história das ciências biológicas. Além disso, estas modificações eram inevitáveis: aplicando as categorias bachelardianas ao domínio da história das ciências da vida, ele teria sido conduzido a nivelar a epistemologia da biologia com a das ciências físico-químicas. $O$ autor não parou de enfatizar a especificidade do vivo: seu "vitalismo" é testemunho suficiente disso.

Canguilhem apresenta A Teoria Celular (1945) como uma "contribuição à psicanálise do conhecimento objetivo": o psicologismo atravessa, então, seu histórico. Porém, ao valorizar mitos, imagens, pressentimentos, antecipações e intuições, Canguilhem faz uma inversão em relação a Bachelard. Assim, dele se afasta, retomando o tema da continuidade em história. Este fracasso é, certa- 
mente, o indício de um problema importante: como pensar, ao mesmo tempo, o entrelaçamento e a separação daquilo.que Bachelard distinguia como história das ciências superada e história das ciências sancionada?

Conhecemos a alternativa: ou bem uma história do tipo descontinuísta traçando os cortes ou bem uma história do tipo continuísta traçando as ligações. Mas como entrelaçar e separar o passado e o presente de uma ciência? Para satisfazer a esta dupla exigência, é necessário multiplicar os pontos de vista, isto é, explicitar os diferentes estratos do terreno teórico fazendo nascer um conceito científico. Em A Formação do Reflexo (1955), Canguilhem desfaz e alimenta a trama do imaginário e do conceitual. Ele também ajusta contas com a antecipação cartesiana e estabelece, tendo em vista o desenvolvimento ulterior do conceito de reflexo, de que modo a teoria de Descartes foi ativada por um outro viés. Ele remonta, enfim, até o passado atual de um conceito e assinala a função positiva das teorias vitalistas: função que é da ordem da compreensão da vida como dado original.

É determinando o estatuto epistemológico dos conceitos de "supervalorização", de "ideologia científica" e de "normalidade" que Canguilhem funda a conjunção dos temas da continuidade e da descontinuidade em história da biologia. A maior parte dos artigos, onde sistematiza o método histórico que estava sendo trabalhado no estudo da formação do conceito de reflexo, foi reunida em Ideologia e Racionalidade na História das Ciências da Vida (1977). Entre o projeto de 1945 e sua realização, por volta dos anos 1970, o estudo da formação do conceito de reflexo marca uma etapa decisiva.

Evidentemente, a escolha destes trabalhos de história é comandada por um problema: a elaboração progressiva de uma história técnica própria à história das ciências da vida. Donde a formação de filiações de acontecimentos metodológicos marcados por afastamentos significativos. Canguilhem parte da história de uma teoria para chegar à história dos objetos biológicos, passando pela história de um conceito.

Contudo, O Normal e o Patológico (1943) é, sem dúvida, o livro mais importante de Canguilhem. Só uma leitura distorcida desta obra poderia conduzir à convicção segundo a qual ele ilustraria, diferentemente de seus estudos ulteriores, uma concepção "biologista" da história. Ao contrário, são as implicações filosóficas de sua tese de medicina, acrescidas de Novas Reflexões (1963-1966), que conferem uma secreta unidade e uma sólida coerência a toda a obra histórico-epistemológica.

1. Em A Teoria Celular, Canguilhem aplica um princípio de inversão: onde a epistemologia bachelardiana traçaria descontinuidades, seria preciso, antes, ver a continuidade histórica do saber. A aplicação deste princípio comporta certas 
exigências de método: descobrir condições de possibilidade e não obstáculos; registrar filiações e não rupturas; inscrever em uma história do sancionado aquilo que, à primeira vista, pertenceria à história do superado. Sem dúvida, CanguiIhem reativa um tema com o qual Bachelard havia rompido: a continuidade. Mas não se pode esquecer que seu objetivo é exatamente outro: restituir uma dignidade teórica ao pré-científico (sabemos as ressonâncias que ele desperta) e, para fazer isso, valorizá-lo. Valorização contra desvalorização. Essa inversão é o correlativo de uma tripla decisão: reabilitar mitos e imagens de maneira a thes conferir uma função heurística, ressaltar a significação histórico-epistemológica das construções discursivas e reavaliar as teorias biológicas, enfatizando aquilo que elas visam mais do que aquilo o que elas dizem.

Uma reabilitação dos mitos e das imagens opõe-se à sua depreciação. É preciso, então, libertar-se da idéia segundo a qual o saber se forma por rejeição dos conteúdos imaginários, cuja única função seria a de obstáculo. Daí algumas operações ricas de implicações. Ressaltar a sobredeterminação dos objetos biológicos mostrando, por exemplo, que os vocábulos tecido e célula são sobrecarregados de significações extrateóricas. Interrogar-se, também, sobre o sentido e o alcance das imagens da continuidade e da descontinuidade. Reconhecer nelas temas de imaginação familiares, estabelecer seu parentesco com as maneiras de pensar e, finalmente, reencontrar sua matriz mitológica. As palavras célula e tecido evocam representações da estrutura viva que se opõem, como os tipos de imaginação que elas exprimem, às exigências mecanicista e vitalista que traduzem e os métodos analítico e sintético que essas exigências ilustram. Descrevendo este movimento de oscilação do pensamento humano entre estes princípios antagônicos, Canguilhem reencontra sua antiga proveniência: o plasma inicial, substância fundamental e contínua que não se parou de invocar contra uma explicação corpuscular, "seria esse plasma inicial outra coisa seno um avatar lógico do fluido mitológico gerador de toda vida, da onda espumante de onde emergiu Vênus?"' (Canguilhem, 1967:78).

Uma revalorização das significações de uma construção discursiva se opōè à sua desvalorização. É necessário, então, romper com a idéia segundo a qual o saber deve ser purificado ou, antes, isolado de seu caráter de irracionalidade. Em lugar de considerar a negatividade de uma construção discursiva para suprimi-la do conhecimento científico, é preciso estar atento a seu núcleo positivo de modo a mostrar que ela pertence à história da formação do saber. Por exemplo, não se deve situar a obra de Buffon em um "museu de horrores", nem o pensamento de Schelling aquém ou além do pensamento científico. Deve-se, antes, ver, na primeira, um "tema de sonho teórico" e, na segunda, a razão pela qual Oken pode ser considerado um precursor: "Entre Oken e os primeiros biólogos conscientes de achar nos fatos de observação os primeiros assentos da teoria celular, a filiação se estabelece sem descontinuidade" (Canguilhem, 1967:59). Buf- 
fon traduziu Newton, e Oken pertence à escola romântica dos filósofos da natureza fundada por Schelling. Da mesma maneira que uma concepção corpuscular da matéria e da luz origina uma concepção corpuscular da matéria viva, o conceito de totalidade, importado da filosofia para o domínio da biologia, vem enriquecer e complicar a questão da composição dos organismos. As teorias de Buffon e de Oken exercem, assim, uma função de conhecimento: discursos fronteiriços e discursos com pretensão de cientificidade, uma vez que basta insistir sobre sua positividade para situá-los no campo do saber. E a operação é irreversível: a teoria das "moléculas orgânicas" como "pressentimento" e a teoria de Oken como "antecipação" testemunham a integração das pesquisas passadas no processo ininterrupto da formação do discurso científico.

A reavaliação de uma teoria passada se opõe à sua depreciação do ponto de vista único da epistemologia. Trata-se de banir a idéia segundo a qual o presente da biologia não poderia confirmar, a posteriori, uma teoria cujo sentido é unicamente metafórico. Ao invés de inscrever uma teoria passada em um passado não atual, é necessário estabelecer sua atualidade, considerando, porém, a recorrência em um plano diferente daquele em que se opera habitualmente a divisão entre o verdadeiro e o falso. Nele, podemos ver o afrontamento das tendências do pensamento em biologia. Opõem-se, aqui, os pontos de vista de um espírito científico dividido: vitalismo contra mecanicismo, totalidade contra atomicidade. Tomemos o exemplo do caráter reticente do pensamento de Auguste Comte a respeito da teoria celular fundada pelos naturalistas alemães. Esta teoria traduziria a preponderância da orientação mecanicista e analítica em biologia. Basta lembrar o vitalismo de Auguste Comte e suas concepçōes sociológicas para compreender a natureza de sua omissão. Em sociologia, o indivíduo é uma abstração; da mesma maneira, as "mônadas orgânicas", como diz Auguste Comte referindo-se às células, são abstrações. Ele não vê em que poderia consistir nem a organização, nem a vida de uma simples mônada. É à luz do presente que Canguilhem avalia esta omissão. Recentemente, pôde-se mostrar que abaixo de uma quantidade mínima de células a multiplicação celular é impossível: pôde-se mostrar que um fibroblasto isolado em uma gota de plasma sobrevive mas não se multiplica. Eis alguns fatos que, retrospectivamente, justificam as omissões de Comte: "De que Comte é culpado ao ter pressentido estas questōes a não ser de ter antecipado estes fatos?" (Canguilhem, 1967:66).

Vemos bem por que este princípio de inversão se revela ao mesmo tempo fecundo e intricado. Ele é fecundo porque sua aplicação produz algumas inovações de ordem metodológica. Valorizar em bloco o pré-científico é conferir uma dignidade teórica aos mitos, às imagens, às construções discursivas e, por fim, à intuição biológica que a teoria comtiana exprime. É intricado na medida em que a inversão do conjunto das categorias bachelardianas conduz inelutavelmente a um evolucionismo em história. Primeiramente, a teoria celular parece inserir-se 
em antigas representações: verifica-se um discurso linear que acolhe imagens muito velhas. Em seguida, o projeto de estabelecer filiações se traduz pela localização de pressentimentos e de antecipações. Donde uma história contínua que pressupõe a delimitação de um terreno teórico sem ruptura: nenhuma linha de clivagem, mas ligações e encadeamentos. Enfim, o tema vitalista da vida como dado irredutível a uma soma de partes, que é uma "orientação permanente" da pesquisa em biologia, autoriza a superposição de uma omissão passada e de uma reserva presente. Daí, uma história teleológica que funciona como um telescópio, em nome da idéia da totalidade do todo, voltado para uma incompletude fundada em valores extrateóricos e uma reserva apoiada sobre uma experimentação autenticamente científica.

Contudo, seria incorreto deduzir deste estudo que Canguilhem abraça sem reserva uma história do tipo continuísta. Sem o parecer, o tema da descontinuidade persegue, contudo, a história da teoria celular. Canguilhem compreende que uma mitologia e uma teoria científica não podem ser colocadas no mesmo plano, e que, querendo derivar a segunda da primeira, corremos o risco de estabelecer uma genealogia fantasiosa. Compreende, também, que as teorias de Buffon e de Oken não estão à altura das ambições às quais devem seu aparecimento e que elas deveriam ser, antes, excluídas do saber. Compreende, enfim, que uma oposição à validade irrestrita da teoria celular não tem a mesma significação quando se exprime em nome de valores filosóficos e sociológicos ou quando se funda sobre os resultados de uma experimentação bem conduzida.

Deste estudo, podemos concluir que o pensamento de Canguilhem oscila entre duas posições em história. E que esta hesitação é o indicador de uma dificuldade por ele avaliada: como satisfazer a esta dupla exigência da continuidade e da descontinuidade em história? Tratar-se-ia, em resumo, de fazer duas operações aparentemente contraditórias. Em primeiro lugar, descrever os vínculos que unem antigas representações e uma teoria científica, porém sem renunciar à avaliação da distância que separa uma da outra. Em seguida, estabelecer a ligação entre uma construção discursiva e uma teoria científica, mas sem deixar de assinalar um corte, já que a primeira, longe de ocupar uma região científica, apenas a bordeja. Mostrar, enfim, que uma teoria biológica pode ser, por retrospecção, justificada por aquilo que ela visa, mesmo que esteja depreciada por aquilo que diz.

Para operar a conjunção dos temas da continuidade e da descontinuidade em história, é preciso afastar-se do psicologismo e de uma epistemologia unipolar. Do psicologismo, na medida em que a alternativa está entre a valorização do pré-científico e sua desvalorização: aqui não se pode estabelecer as continuidades uma vez que registram-se obstáculos e rupturas; lá, ao contrário, não se podem marcar as descontinuidades, já que descobrem-se condições de possibilidade e encadeamentos. De uma epistemologia unipolar, pois é necessário escolher 
entre duas formas de recorrência. A primeira funciona no nível das orientaçōes das teorias, enfatizando a atualidade de um tema; porém, ao descrever a permanência dt uma orientação do pensamento em biologia, faltam-lhe as descontinuidades. A segunda funciona no nível do conteúdo das teorias, assinalando a superação das conceitualizações; mas marcando atos epistemológicos superados, faltam-lhe as continuidades.

Este duplo afastamento foi possivel devido à passagem da história da forma. ção de uma teoria à história da formação do conceito. Com efeito, é fazendo a his. tória do conceito que podemos afirmar que uma mitologia e uma metáfora podem contribuir para a formação da ciência e, ao mesmo tempo, dela serem excluídas. ainda no plano da história do conceito que podemos ser levados a perguntar o que uma construção discursiva deve conter para que o conceito possa ter um sentido de verdade; daí a distinção entre uma teoria que autoriza a formação de um conceito $\epsilon$ aquela que o encobre. Neste caso, há a possibilidade de desempenhar, algumas vezes, um papel positivo no desenvolvimento ulterior do saber. É, finalmente, no plano da história do conceito que podemos fazer aparecer a inatualidade do conteúdo de uma teoria; é, contudo, trabalhando nesta região mediadora, situada a meio caminho da teoria e do objeto, que podemos reorientar a teoria em direção ao objeto e mostrar a atualidade de seu ponto de vista.

2. Em A Formação do Reflexo, Canguilhem aplica um princípio de conjunção, do qual resulta a reativação das categorias bachelardianas que se acham agora associadas às suas opositoras. Em outras palavras, trata-se de utilizar concomitantemente as categorias de obstáculo e de condição de possibilidade, de corte e de ligação, de superado e de atual. Três decisões decorrem destas três dicotomias. De um lado, estabelecer que mitos e imagens têm função primordial na elaboração de um conceito científico, mas, também, mostrar que a fisiologia nascente revela, por retrospeç̧ão, a natureza do obstáculo tanto de uma mitologia "da chama" quanto de uma metáfora ótica. De outro lado, assinalar até que ponto uma construção discursiva, como a teoria cartesiana do movimento involuntário, deve ser ao mesmo tempo excluída do espaço do saber e incluída na história do reflexo. Enfim, ordenar uma dupla recorrência de maneira a situar uma teoria biológica no ponto de cruzamento entre um passado atual e um passado superado.

Para evidenciar a duplicidade dos conteúdos imaginários, não é necessário que acreditemos que o saber não passa de uma metamorfose do mito ou, inversamente, que as premissas fantásticas constituem entraves ao conhecimento. É preciso, antes, ver como a sobredeterminação de um objeto biológico pode ser, ao mesmo tempo, a possibilidade de um movimento e de um bloqueio do pensamento. A produção de um conceito a partir de analogias que valem como condições de possibilidade implica um desempenho que as situa no campo dos obstáculos ultrapassados. 
A analogia tem o estatuto de condição de possibilidade, tendo em vista o uso científico que Willis dela faz em fisiologia neuromuscular. Com efeito, Willis se refere à teoria da alma ígnea e reconcilia-se assim com a imagem primordial do espírito fogo, uma mitologia da "chama". Sabemos como se opera a assimilação da alma pelo fogo e pela luz: na extremidade da chama, uma vibração apenas visível substitui a incandescência e, como diria Bachelard, o fogo se desmaterializa, ele se torna espírito. $O$ fogo como antagônico ao peso, assim como a ação como violência impressa no organismo induzem à idéia de oposição entre poder e resistência. A conjunção destes dois temas dá conta do fato de que o fogo e a luz deviam ser considerados como a matéria da alma e o órgão da animação do corpo. Vemos que a palavra "espírito animal" evoca a imagem de uma substância inflamável; o espírito animal é luz, fogo, iluminação e, no músculo semelhante à câmara do canhão, deflagração. Willis inventa, então, a palavra e o conceito de movimento reflexo no contexto de uma teoria do influxo nervoso mais imaginária do que experimental: "Ele chega a um conceito de devir a partir de analogias hoje tomadas como metáforas "(Canguilhem, 1955:157).

Mas descrever como um conceito científico nasce dos fascínios do imaginário é também estabelecer que seu aparecimento supõe algo como um rasgo no tecido das crenças. Donde a ruptura de problemas e de objetos com relação aos temas mitológicos. No limiar da idade clássica, o destino desta mitologia da "chama" dá suficiente testemunho disto: "Na teoria da alma ígnea de Willis como na teoria do fogo cardíaco, 'fogo sem luz', de Descartes, morre, após sua divisão na aurora da fisiologia moderna, a mitologia da chama" (Canguilhem, 1955:88). "Esta crença, que remonta à noite dos tempos, não está fora do tempo. Não a vemos nascer; em compensação, a vemos desaparecer, uma vez que uma ciência vem ocupar seu lugar. Podemos pensar, se quisermos, que esta mitologia morre e renasce em cada um de nós. Para o historiador, ela se transforma em cinza para sempre, isto é, em obstáculo superado.

Para fazer aparecer a dupla função de uma construção discursiva, é necessário deixar de considerar que ela tem o estatuto de uma antecipação ou, ao contrário, que ela se opõe inteira ao advento do saber. É preciso, antes, dissociar seus componentes, de modo a atribuir-lhe um papel negativo ou um papel positivo.

É porque Canguilhem se esforça para compor uma história do reflexo sem "discriminação ideológica a priori" que ele encontra, na história, elementos para fazer uma discriminação ideológica a posteriori. Ao estabelecer que é Willis quem inventa o conceito de reflexo, ele é conduzido a mostrar que as concepções anatomo-fisiológicas de Descartes constituem obstáculos, proibindo-o de forjar este conceito. Donde a possibilidade de julgar o valor da teoria cartesiana: afastada do espaço do saber, ela é desqualificada nas suas pretensões científicas. A teoria cartesiana usurpava um título ao qual ela não tinha direito. E quando o 
conceito de reflexo aparece, não é onde era esperado, mas em um contexto vitalista. Com a formação do conceito de reflexo por Willis, assistimos a um processo de "deposição" de uma teoria pseudocientífica.

Todavia, a teoria cartesiana não deve ser totalmente excluída da história do movimento reflexo. A história da fisiologia não deve a esta teoria a formação do conceito de reflexo, mas deve outra coisa. É o que Canguilhem estabelece quando afirma que Galeno e Whytt concebiam o movimento involuntário como movimento voluntário ou refletido, mas tornado inconsciente ou automatizado pelo hábito. Eles enunciavam, com precisão, a teoria de que a noção de reflexo deve ultrapassar, antes de se constituir, na medida em que representa um obstáculo interno à sua constituição: "É por ter ultrapassado este obstáculo que Descartes tem sua parte que não é pequena, mas diferente daquela que, em geral, Ihe é atribuída na história do reflexo" (Canguilhem, 1955:149). A teoria cartesiana, levando em conta seus efeitos destruidores, deve então ser inscrita na história do reflexo.

Para explicitar os dois pontos de vista segundo os quais podemos avaliar, à luz do presente, o valor das teorias biológicas, não é preciso crer nem que a recorrência se aplica apenas às orientações do pensamento sobre o biológico nem, inversamente, que deve conduzir a abandonar aquilo que não pertence ao passado atual. É necessário, ainda, distinguir a função e o conteúdo de uma teoria biológica, de modo a estabelecer, por retrospecção, a atualidade da função e a superação do conteúdo.

A atualidade das teorias vitalistas deve-se ao fato de que é em seu contexto que um conceito científico encontra as condições de seu aparecimento e de sua elaboração progressiva. Willis inventa o conceito de reflexo, que só é definitivamente formado por volta de 1800; portanto, só depois que Whytt, Unzer e Prochaska desenvolveram seu caráter lógico e experimental. Ora, as teorias como contexto, em que o conceito é sucessivamente elaborado, não remetem a nada mais que à sua função. $O$ valor das teorias vitalistas relativas ao funcionamento do sistema nervoso reside nesta consciência aguda da especificidade dos fenômenos biológicos: "Num organismo qualquer, uma relação autêntica e não simulada, natural e não artificial, de retroação exige uma individualidade irredutivel a um composto. Unzer e Prochaska, assim como Whytt, não afirmavam, à sua maneira, outra coisa" (Canguilhem, 1955:157). O que conduz o pensamento vitalista tão depressa a seu fim é, então, esta intuição quanto ao sentido dos fenômenos biológicos. Eis porque estas intuições devem figurar em uma história iluminada pela finalidade do presente.

Mas estas teorias vitalistas são também inatuais. De uma parte, enquanto fundo teórico onde se delineia o conceito de reflexo e, de outra, porque, com elas, os vitalistas exprimem, à sua maneira, esta consciência da especificidade dos fenômenos vivos. O emprego dos termos "princípio vital", "força vital" e "força 
nervosa" é, com efeito, o indicativo de uma impossibilidade de conceitualizar estas intuições biológicas. É porque elas pretendem atingir a vida em termos metafísicos que as teorias inspiradas no animismo e no vitalismo devem ser abandonadas. Com a história do reflexo, desdobra-se a recorrência concernente ao conhecimento da vida como ordem original de fenômenos. Surge uma história das crispações ou, antes, das impaciências do pensamento biológico; uma história de seus pontos de vista ao mesmo tempo penetrantes e superficiais. Penetrantes, já que a reflexão recorrente justifica estas teorias naquilo que elas apontam; superficiais na medida em que apaga as entidades metafísicas.

Não há indecisão nesta história das ciências quando se trata de exigências da continuidade e da descontinuidade. Primeiro, no momento mesmo em que Canguilhem mostra o que a descoberta de Willis deve a uma mitologia e a uma metáfora, elas são relegadas ao esquecimento. O questionamento da noção de sobredeterminação revela aqui sua polivalência. Em seguida, ele distingue as funções negativa e positiva da teoria cartesiana do movimento animal: de um lado, esta teoria não autoriza a formação do conceito de reflexo, de outro, ela contribui com a sua purificação ulterior. Em conseqüência, o estudo desta formação discursiva faz ressaltar sua ambivalência. Por fim, a relação entre as teorias vitalistas e os fenômenos vivos assinala a emergência de uma nova relação, ponto de aplicação de uma recorrência bipolar. Com efeito, uma justifica o sucesso das teorias biológicas pela exigência vitalista, ao passo que a outra a critica, afirmando que esta exigência se traduz em termos pseudocientíficos.

Com a história da formação do conceito de reflexo, Canguilhem enfatiza explicitamente o entrelaçamento e a disjunção do superado e do sancionado. É fazendo a história de um conceito que um problema de metodologia histórica encontra sua solução. Porém, a complexidade da problemática da história das ciências deixava em aberto uma questão. A refutação dos resultados vitalistas em nome do mecanicismo o indica: "Se, como G. Canguilhem afirma, foram os vitalistas e não os mecanicistas que descobriram o reflexo, isto, na verdade, é uma homenagem que os primeiros renderam, senão ao mecanicismo de Descartes, ao menos às intuições causais das quais procedem" (Piaget, 1987:897). Notemos que a dita homenagem supõe a subordinação do vivo ao determinismo físico-químico, isto é, a um reducionismo. Como então se opor à possível confusăo de duas problemáticas históricas? Para marcar a especificidade da epistemologia da biologia, Canguilhem estabelece o estatuto epistemológico de uma série de conceitos que são estranhos à epistemologia das ciências da matéria.

Por volta dos anos 70, Canguilhem elabora uma nova teoria da história das ciências. Ele transpóe um princípio de utilidade (uma idéia diretriz da biolo-: gia) para a interrogação sobre o sentido vital da constituição do saber na história. Isto o leva a registrar uma exigência permanente da vida no vivo expressa em três 
modalidades: uma mitologia que traduz uma necessidade de acesso à totalidade, uma construção discursiva que responde às necessidades de ordem prática, e as conceitualizações vitalistas que exprimem subordinação ao fato da vida. Porém, ao introduzir um fator instintivo, quer dizer, os interesses vitais do vivo humano, Canguilhem subordina a história a uma epistemologia aprimorada: uma necessidade de acesso à totalidade se manifesta por uma "supervalorização" da vida; necessidades de ordem prática ocasionam a construção de modelos de uma medicina operatória designados pelo conceito de "ideologia científica"; a especificidade dos objetos biológicos à qual se submete o pensamento da vida é designada pelo conceito de "normalidade". As questóes da supervalorização da vida, de sua preservação e de sua definição assinalam o aparecimento de uma história dos objetos biológicos.

Não somente o nível das análises se desloca do conceito para os objetos, como também o campo de aplicação é diferente. Com efeito, Canguilhem passa de uma escala microscópica a uma escala macroscópica da história das ciências. Em outras palavras, seu interesse é centrado nos começos lentos, mas, também, nas bruscas mutações que caracterizam o passado próximo da biologia. De um lado, esta história é descrição do desmoronamento de uma mitologia, das construções discursivas e das conceitualizações pré-científicas. De outro, esta história traz à luz o que elas contêm de força propulsora. Seríamos tentados a dizer que, para Canguilhem, a oposição entre as duas linhas é um fracasso: a uma se deve a positividade do erro como presunção de verdade, à outra se deve a negatividade enquanto destruição pela verdade. A clivagem entre as categorias de obstáculo, ruptura e abandono, por uma parte, e as de condição de possibilidade, ligação e prolongamento por outra, se passa no interior da ilusão. A ilusão que não tem futuro, mas está sempre por vir, uma vez que a história continua.

3. Ao aplicar o conceito de supervalorização a uma mitologia, Canguilhem funda sua polivalência: ela é ao mesmo tempo condição de possibilidade do conhecimento da vida e seu obstáculo. Ao ser abandonado como erro vital, o mito é revelador de uma necessidade de acesso à totalidade. Ora, a prova da realidade confirma o fracasso de uma mitologia. Eis porque, ao proporcionar à ciência seus objetos, que são seus problemas, uma mitologia pode ser tomada como condição de possibilidade do saber. Canguilhem nunca deixa de lembrar que a medicina começou sendo uma arte e que a filosofia deve suas questões à clínica, ou melhor, a uma velha herança feita de mitologias e de rituais. Se o conceito de doença se confunde com estas mitologias e estes rituais, é o sofrimento consecutivo ao fracasso das práticas que dissipa a segurança ilusória que elas proporcionam. $\mathrm{O}$ interesse pelo conhecimento da vida deriva, então, de um interesse mais originário suscitado pelos projetos de cura fadados ao insucesso. 
Porém, mostrar que uma mitologia desaparece como erro vital é afirmar que ela está destinada a se esvanecer como ilusão, exprimindo uma vontade de potência que é negação dos limites que a própria vida impõe aos vivos. Ora, a determinação destes limites é o objeto mesmo do saber. Uma mitologia, ao se opor ao conhecimento da vida, constitui também um obstáculo. Por exemplo, as diferentes verses pseudocientíficas do tema da geração espontânea manifestam a persistência de um mito relativo à origem da vida. Canguilhem, no artigo "Vida" lembra que o mito do nascimento do herói é um argumento complementar da teoria que Otto Rank desenvolve em O Traumatismo do Nascimento. Os mitos de negação parecem confirmar a idéia de que a separação da criança do meio placentário é a origem e o modelo de toda angústia. É preciso então perceber na aversão ao nascimento e à gênese, que não passam de sucesso e descendência, um efeito do prestígio do original. Certamente, Canguilhem não pretende que todos os partidários do que se chamou a geração equívoca ou a heterogenia não fazem mais do que colocar em forma de discurso o fantasma originário de seu inconsciente traumatizado, mas "permanece a idéia de que a teoria da geração espontânea é uma supervalorização da vida, portanto, um obstáculo à inteligência do objeto biológico" (Canguilhem, s/d:766b-c).

O conceito de ideologia científica designa estes modelos da medicina cirúrgica e funda sua ambivalência: eles devem ser separados e ligados ao presente da ciência. Uma ideologia científica deve ser ligada ao presente da medicina, porque ela pode constituir uma etapa epistemologicamente necessária para que surja uma medicina capaz de executar seu projeto. Da "medicina fisiológica" de Broussais não resta nada. Entretanto, este sistema teve efeitos subversivos: graças a ele assiste-se ao desaparecimento da ontologia médica e de uma nosologia essencialista. Magendie, por sua vez, impõe uma nova orientação em medicina, na medida em que esta última lhe deve um triplo deslocamento: de lugar (do hospital ao laboratório), de objeto (do homem ao animal) e de modo (da preparação galênica ao princípio ativo isolado pela química). Enfim, a leitura de Claude Bernard, que identificava doença e envenenamento, pôde contribuir para facilitar a compreensão do mecanismo da infecção. O princípio de identidade entre o normal e o patológico, que tem sua fonte na obra de Brown, foi admitido por Broussais, Magendie e Claude Bernard. Este princípio, que justifica um ativismo médico, se opõe então à antiga medicina expectante: "Este princípio fundou uma ideologia, aquela do poder ilimitado da medicina, uma ideologia médica liberada de todo compromisso com o hipocratismo" (Canguilhem, 1977:53-54). Uma ideologia médica que talvez também tenha contribuído para tornar acolhedor ao espírito dos médicos, químicos e biólogos a idéia tecnicista de violar a natureza com fins terapêuticos. 
Mas uma ideologia científica também deve ser separada do verdadeiro conhecimento. Mostrar que ela desaparece como "pseudo-saber" é descrever o seu desaparecimento como ilusão, exprimindo uma vontade de fundar teoricamente a terapêutica. Ora, esta ilusão é um desconhecimento das exigências metodológicas e das possibilidades operacionais da ciência que virá ocupar seu lugar. É fácil evidenciar a defasagem da terapêutica em relação aos modelos de uma medicina cirúrgica. Afastamento, portanto, das terapêuticas de Broussais, Magendie e Claude Bernard com relação ao "fisiologismo" do primeiro e à "medicina experimental" dos dois últimos. A atitude face às doenças infecciosas, que não entravam no quadro definido pelo princípio da identidade dos fenômenos orgânicos normais e patológicos, testemunha claramente a impotência destas "teorias médicas". Canguilhem faz alusão ao fracasso dos tratamentos fisiológicos anti-estimulantes de Broussais, à posição anticontagionista de Magendie a propósito do cólera e, para finalizar, à idéia de Claude Bernard segundo a qual doenças como a varíola, o sarampo e a escarlatina respondem a funções da pele que ainda são ignoradas. Era preciso, como mostra Canguilhem, uma revolução na química e na técnica mas, sobretudo, o desvio pastoriano por meio da cristalografia, para que a quimioterapia sustentasse a promessa da ideologia.

$\mathrm{O}$ conceito de normalidade, que designa a originalidade distintiva dos organismos vivos, funda uma dupla recorrência. Tal recorrência legitima e enfraquece, ao mesmo tempo, as conceitualizações pré-científicas da vida. De sorte que estas conceitualizações devem ser prolongadas, por um lado, e abandonadas, por outro.

Em A Questão da Normalidade, Canguilhem definiu o objetivo que atribui à sua história da biologia: a descrição das etapas que marcam a constituição daquilo que uma disciplina considera como seu objeto próprio, isto é, objetos específicos sem equivalentes mecânicos ou, ainda, "estruturas da ordem da confiabilidade e, ao mesmo tempo, da falibilidade". Estes conceitos axiológicos são nivelados ao final, que é provisório, de sua trajetória na história. Mas é suficiente nos remeter ao capítulo inicial da história da biologia para constatar que pesquisa e ação já eram indissociáveis da referência a valores vitais. Aristóteles, naturalista, ordena a série animal segundo a hierarquia, do perfeito ao imperfeito, enquanto Hipócrates, médico, orienta sua terapêutica em função de uma reflexão sobre o normal e o anormal. Tanto no caso da história natural (Aristóteles, Maupertuis, Buffon, Darwin) como no da história da fisiologia (Aristóteles, Descartes, Stahl, Claude Bernard) as filiações são justificadas, levando-se em conta a referência a conceitos normativos. Daí, a idéia de que o sucesso das definições do vivo está subentendido em uma espécie de "princípio de conservação temática". Em suma, as imagens e as metáforas da normalidade testemunham o esforço permanente de uma definição da vida que não deixa escapar sua originalidade. Estas antecipaçóes inábeis, mas adequadas, devem ser estendidas. 
Aparentemente, esta história da biologia desconhecia a descontinuidade, já que o corte parece coincidir com a origem. Mas, considerando que os objetos biológicos são correlatos de um pensamento que não cessa de os objetivar diretamente, desde a Antigüidade até nossos dias, Canguilhem propõe uma história da vida que está longe de excluir uma história das variações desta temática. Daí, uma atenção centrada nas diversas "manifestaçōes" do princípio de conservação. Donde resulta uma história, que progride por etapas, registrando o deslocamento da superfície do plano da inteligibilidade - em que se legitimam os aspectos normal e anormal dos modos de existência dos organismos vivos - para a profundidade do vivo. Esta atenção à sucessão histórica destes diferentes níveis de apreensão dos fenômenos da normalidade é crítica: determina a natureza "pseudo-teórica" das conceitualizações pré-científicas. Eis porque estas últimas devem ser abandonadas, mas abandonadas como ilusões que traduzem uma vontade de afirmar a originalidade da vida tal como ela é percebida ou pressentida, isto é, próxima de seu objeto dado e não distante de seu objeto construído.

Canguilhem concorda com a idéia nietzscheana segundo a qual a importância de um "progresso" se mede pela grandeza dos sacrifícios que the devem ser feitos. Para ele, os méritos daqueles que a história abandonou, pelos caminhos por ela mesma rejeitados, "são medidos por sua relação indireta com a obra coletiva elaborada sem eles" (Canguilhem, 1977:77). O progresso ou o avanço de uma ciência não resulta do acúmulo de conhecimento. Procederíamos mal ao tomar a ambição de uma mitologia, o projeto de uma ideologia científica e o princípio de conservação temática, como indicativos de uma história orientada, quer dizer, progredindo em direção a uma finalidade. Esta história é, antes, aquela das diferentes tentativas de assujeitamento dos objetos em campos teóricos e práticos heterogêneos, independentes e, algumas vezes, sobrepondo-se uns aos outros. Ao mesmo tempo, podemos perceber como Canguilhem joga com a antinomia das categorias epistemológicas. Se uma mitologia é condição de possibilidade do saber, é somente enquanto permite apreender os fracassos como dificuldades no campo da prática científica em seu devir. Se a promessa da ideologia é mantida, é "de outro modo e num outro terreno". Se as conceitualizações pré-científicas dos fenômenos da normalidade são conservadas, é "somente enquanto deslocamento, cuja função é de indicador de uma originalidade objetiva". Este triplo movimento ocasiona, sem contradição, a inversão das categorias: uma mitologia é também um obstáculo, uma ideologia científica aparece em um ponto de ruptura e, enfim, as conceitualizações pré-científicas devem ser abandonadas.

É a colocação à prova dos conceitos de supervalorização, de ideologia científica e de normalidade que assegura o funcionamento regulado dos três pares de categorias anteriormente formadas por ocasião da história do conceito de reflexo. Mas, com estes conceitos epistemológicos, aparece, também, o tema da 
representação dos significados da formação de uma ciência em seu devir. Deste ponto de vista, esses conceitos epistemológicos exprimem uma vontade de vida cujo efeito, invariavelmente, é superação. Não assinalam eles também a emergência, no domínio da história das ciências, de uma série de questóes que estavam no âmago da reflexão de Canguilhem desde 1943? Daí, o interesse em retomar o ensaio sobre $O$ Normal e o Patológico.

4. É necessário trazer de novo estes conceitos epistemológicos ao seu contexto médico, científico e filosófico, que tornou possível, há muito tempo, seu aparecimento. Uma mitologia, indício de uma supervalorização da vida, manifesta uma vontade de dominação; uma ideologia científica exprime uma vontade de ação; o conceito de normalidade designa, enfim, aquilo que o vitalismo sempre tentou alcançar. Estes temas se enraízam em uma reflexão sobre as questões do conhecimento, da ação e da vida. Quem tentasse aqui encontrar os problemas tradicionais do conhecimento, da moral e da existência desconheceria a novidade de um pensamento voltado para a questão do valor e da norma. Com efeito, o pensamento de Canguilhem gira em torno da medicina precisamente situada no ponto de verificabilidade do saber, da ação e da vida. Do saber, em primeiro lugar: o conceito de supervalorização está ligado à questão da relação entre o conhecimento e seu objeto. Do acaso, em seguida: o conceito de ideologia científica se prende à questão das relações entre ciência e técnica. Da vida, enfim: o conceito de normalidade relacionase à questão das normas e do normal.

Ao procurar o sentido originário de todo ato de conhecimento no vivo, Canguilhem renova a questão da relação entre o conhecimento e a vida. Para ele, o conhecimento e a vida são objetos de uma valorização, mas de uma valorização unificada: pensamento e conhecimento se estabelecem, do ponto de vista do homem, na vida, para orientá-lo. Canguilhem compreende a ciência, que pode se transformar em ato, como uma atividade do vivo humano, cujo valor, aliás, não é maior nem menor do que o da atividade dos vivos no humanos. Ele inclui, então, a ciência na vida, e considera a atividade do homem que conhece como pertencente a um capítulo da história da vida: "Estes vivos vivem sua vida tendo como referência espontânea certas exigências de comportamento ou normas de adaptabilidade. A interrogação sobre o sentido vital destes comportamentos ou destas normas, ainda que não se origine diretamente da física ou da química, faz, também, parte da biologia" (Canguilhem, 1977:138) ${ }^{1}$. A este pro-

1 Em La Connaissance de la Vie, Canguilhem já escrevia: "Uma teoria geral do meio, do ponto de vista autenticamente biológico ainda está para ser feita pelo homem técnico e sábio, no sentido do que foi tentado por von Uexküll para o animal e Goldstein para o doente"(Canguilhem, 1967:96). 
jeto de uma teoria geral do meio, talvez se façam duas objeções. Em primeiro lugar, poderemos dizer que o animal, ao contrário do homem, não se engana, pois ele é informado hereditariamente para memorizar e transmitir apenas certas informaçōes. Em segundo lugar, diremos que o pensamento faz do homem um ser vivo bem particular. Mas não devemos esquecer, por um lado, que a formação de conceitos é uma modalidade da informação e, por outro lado, que a função do conhecimento é uma função de decifração fundada no erro. Nietzsche dizia que o conhecimento é o signo da perda da "razão animal sâ". Canguilhem diria mais, que ele é o indício da perda de um sentido, isto é, da ausência de decodificação ou de mutação, pelas quais a vida teria alcançado este ser vivo capaz de erro. Em lugar de acreditar que Canguilhem reativa, assim, um empirismo, devemos, antes, ver como esta idéia se origina de uma reflexão sobre a questão da relação do conhecimento com seu objeto.

Em O Normal e o Patológico, Canguilhem mostra que a concepção positivista da doença é a expressão de uma supenvalorização do saber. Se o vivo humano conhece as relações do mal com o estado normal, então a medicina comporta um poder de dominação. É que a eficácia da ação está fundada na ciência. Eis o programa de um positivismo despótico e tão seguro do seu poder que assimila a função de conhecimento a uma função de comando. Reconhecemos, de passagem, uma das figuras de um sonho demiúrgico: o tema de uma potência ilimitada do homem que se exerceria sobre a natureza e a vida. Ora, este sonho lembra a concepção cartesiana da relação entre o conhecimento e a vida. A supervalorização do saber aponta a separação do pensamento com relação à vida, e, também, o direcionamento do pensamento contra a vida. Se bem que o pensamento não pode reencontrar aquilo que ele imobiliza, substituindo o quantitativo pelo qualitativo. Opõe-se Canguilhem a esta substituição que implica o esquecimento de um fato epistemológico: ao reduzir a relação qualitativa de valores vitais negativopositivo a uma relação quantitativa, desloca-se esta diferença sem para tanto anulá-la. Para desarmar a armadilha do Mesmo e do Outro, é preciso antes pensar que toda atividade humana, seja prática (como a terapêutica), seja teórica (como a ciência), é um desdobramento histórico de significações normativas permanentemente em transformação, mas originariamente restritas à vida.

Com efeito, erro e doença acabam por convergir na direção daquilo que os funda, e que nada mais é do que a falibilidade da vida. Com a introdução do conceito de erro em patologia, questionam-se as perturbações bioquímicas hereditárias e as anomalias de natureza genética. Se bem que, de acordo com uma tal concepção de doença, o mal é radical: "Ele está nas próprias raízes da organização (...) no ponto onde começa não o reino mas a ordem do vivo" (CanguiIhem, 1966:210). E, da mesma maneira que existe materialidade do erro do metabolismo, portanto do mal, existe uma consistência do erro. Em outras palavras, 
o erro do pensamento se enraíza no erro da vida e este é a chave daquele. Retorno a Nietzsche? Com ele, também se compreendia melhor a criação da ciência, uma vez que ele enraizava o saber no erro; porém, quem quer a verdade ou a ciência "afirma, por esta vontade mesma, um outro mundo que não o da vida" (Nietzsche, 1955:289). Portanto, uma mentira. Se o vivo só pode viver cometendo este erro com relação à vida - o erro quer dizer a busca da verdade - ele permanece deste lado da vida que é a invenção e o poder. Este tema da supervalorização da vida fundada na aparência conduz à depreciação do saber pela vida: figura invertida do sonho positivista, uma vez que a supervalorização do saber levaria à negação da vida. Temos aí, talvez, duas versões espetaculares de uma mesma concepção clássica da verdade e do sujeito. O fundamento do conhecimento na vida, que confere um novo estatuto à relação do saber com seu objeto, remete a uma filosofia da ação.

Com efeito, é o conluio do sentido dos termos "erro" e "errância", que parece estar na origem desta idéia de formação de conceitos como uma das modalidades da informação, entre outras. $O$ homem se engana quando ele não sabe onde se posicionar para decifrar; engana-se porque é destinado a errar. Nós acreditamos não trair o pensamento de Canguilhem ao afirmar que o erro e a errância são totalmente semelhantes ao acaso. Trata-se, aqui, de um empirismo inteiramente assumido e mesmo reivindicado. Ficaríamos tentados a acrescentar que ele constitui uma invariante do seu pensamento, o núcleo do seu método histórico. Fazer a história de uma ciência é descrever sua trajetória, seus desvios, seus objetivos e a distância que separa um projeto de sua realização. Em uma palavra, é apreendê-la no seu imprevisível devir. Daí, dois temas complementares: o tema da retificação da ilusão que opera a incessante dicotomia do verdadeiro e do falso, e o tema de uma incessante superação do conhecimento confirmado. A divisão origina-se no saber e na superação da ilusão. Esta última, no mesmo instante em que antecipa aquilo que sabe, ignora os obstáculos que estão por vir assim como aquilo que seu projeto deveria conter em termos de conhecimento para ser bem-sucedido. Quanto à superação, Canguilhem retira do espaço do conhecimento a mitologia, a ideologia científica ou, ainda, para empregar uma palavra que retoma de Fontenelle, a ignorância, "a filha mais velha da ciência a qual a ciência encontra sempre em seu poder" (Canguilhem, 1971:174). O surgimento do conceito de ideologia científica, por volta dos anos 70 , é, portanto, o signo de uma convergência com a questão das relações entre as ciências e as técnicas.

Em O Normal e o Patológico, Canguilhem mostra que o princípio de Claude Bernard da identidade do normal e do patológico traduz a conviç̧ão de que a ciência fisiológica, pelo viés da patologia, seria fundada para determinar a atividade terapêutica. Porém, subordinar a medicina à fisiologia é confundir a atividade tera- 
pêutica com a ciência; é, portanto, recusar à técnica todo valor e toda autonomia. A esta convicção humanista, que subordina a ação ao saber, Canguilhem opõe uma convicção anti-humanista ou, antes, uma convicção realista. Uma atenção voltada para as práticas assinala a inversão do ponto de vista da convicção humanista e a emergência das relações entre as ciências e as técnicas. Ao admitir um interesse pela patologia, pela clínica e pela terapêutica, Canguilhem reconhece sua função heurística. Para ele, uma atividade técnica, não teórica, pode ser a causa de renovações e de reformulações de questões científicas. Além disso, opõe ao racionalismo dogmático um empirismo, que é uma "filosofia do acaso intelectual". É bem verdade que as técnicas, à diferença das ideologias científicas, não admitem este desvio teórico que faz com que Canguilhem localize as últimas na vizinhança do conhecimento. Em contrapartida, ambas devem seu aparecimento às exigências de ordem prática; ambas se fundam nas necessidades da vida e por isto nos parece legítimo aproximálas. Poderíamos, então, afirmar que, em relação à racionalidade, as técnicas e as ideologias científicas asseguram uma função estruturalmente análoga, já que elas podem ter às vezes um papel positivo na constituição do saber. $E$ ainda, a idéia de que a terapêutica constitui a origem dos interesses da fisiologia leva Canguilhem a aplicar a técnica humana, como atividade normativa, na própria vida. É exatamente deste lado da prática médica que podemos descobrir a atividade de uma técnica vital, no silêncio ou no sofrimento da vida, que permite compreender que ela é uma atividade finalizada. É necessário negar a dependência da técnica para com a ciência, ramificando-a na vida: a técnica deriva da vida, prolonga atos naturais e instintivos. E é justamente porque a vida é "atividade de informação" que ela é a fonte de toda atividade técnica, mas também de toda atividade teórica, portanto das ideologias científicas que estão a meio caminho desta e daquela. Vemos, então, aparecer um traço comum a todas estas atividades humanas: a eventualidade do fracasso ou do erro está inscrita na sua história e é por esta razão que esta história deve ser escrita como um "acaso e no como uma decorrência". Ora, a tendência fundamental da vida não é também o afrontamento dos riscos, quer dizer expansão, superação e não mais consenvação? $\mathrm{O}$ acaso representa para a história aquilo que o risco representa para a vida, e a história que não é nem deduzida da vida nem projetada na vida aí se inscreve. Esta filosofia da ação parte do pressuposto da idéia de vida como preferência e excluso, o inverso de uma relação de indiferença com o meio.

Esta idéia de vida como ordem original dos fenômenos, ou como atividade normativa, é devida ao fundador da biologia e não aos inventores do termo, Lamark e Tréviranus. Em Nascimento da Clínica, Michel Foucault confirma "com Bichat, o conhecimento da vida encontra sua origem na destruição da vida, e no seu extremo oposto; é na morte que a doença e a vida falam sua verdade" (Foucault, 1963:248). Canguilhem mostrou que o nascimento conceitual da biologia ocorreu de modo inverso ao do nascimento da física: esta constituiu-se por su- 
pressão de conceitos axiológicos, aquela pela sua adição. Com Galileu e Descartes, a mecânica funda-se no princípio de inércia, apesar de o movimento da matéria deixar de ser atribuído ao poder da vida: a distinção aristotélica dos movimentos naturais e violentos, que resultou de uma mecânica qualitativa, foi invalidada. Com Bichat, a biologia funda-se na oposição entre o natural - que não é o efeito de um determinismo mas o termo de uma finalidade - e o patológico: a vida como poder não pode ser explicada por leis forjadas a partir de hipóteses que the negam esta qualidade. Por ser "longo e tortuoso", o caminho que vai da enteléquia de Aristóteles à enzima do bioquímico é o mesmo. Para chegar à definição do objeto biológico, Canguilhem distingue duas coisas: de um lado, aquilo que ela tem de relativamente estável, o ponto de vista, a função de índice; de outro lado, o elemento mutável, todas as coisas relacionadas às conceitualizações deste ponto de vista. Ora, a vida não é conservadora e inovadora? Denunciar uma concepção biológica da história seria uma grande tentação. É preciso, antes, registrar uma convergência da relação, tanto do método, quanto do conteúdo, com a questão das normas e do normal.

Em O Normal e o Patológico, Canguilhem nota que o princípio de identidade do normal e do patológico de Claude Bernard traduz a "convicção do otimismo racionalista de que não há realidade do mal" (Canguilhem, 1966:61). Esta convicção se opõe a toda concepção ontológica da doença. Ao contrário, se se estabelece uma diferença qualitativa entre o normal e o patológico, o conceito de mal tem um sentido. Ora, esta idéia comporta a conviç̧ão do pessimismo empirista. Canguilhem faz, então, uma inversão do ponto de vista da conviç̧ão, assinalando a emergência da questão da normatividade biológica. Uma referência histórica reforça a dissonância das teses. A Broussais, inimigo de toda ontologia, se opõe uma tradição médica dualista representada por Paracelso, Van Helmont e Stahl. Esta medicina, sem dúvida, está errada ao pensar que o mal é um ser, mas ela tem razão quando confere um sentido ao conceito de doença. Se bem que o vitalismo importa menos pelo seu conteúdo do que pelo que indica: ao verificar a realidade da normatividade da vida, o vitalismo, longe de deixar escapar o problema dos valores, designa o cerne da questão. Certamente, os termos "princípio vital", "idéia" e "arché" são menos precisos e menos explícitos que as imagens de "desenho", "plano", "idéia diretriz" ou "ordem". Mas entidades metafísicas, imagens e metáforas são suscitadas pela mesma exigência vitalista e devem seu aparecimento ao "reconhecimento do fato da organização": a decodificação do programa genético legitima, a posteriori, todos estes pontos de vista.

Contudo, Canguilhem não esperou esta descoberta para avaliar o vitalismo no qual ele vê uma biologia de médico: vitalismo e naturismo são indissociáveis. É necessário, ainda, voltar à medicina para criticar a idéia de que ela toma emprestada da fisiologia a noção de norma. Sem dúvida, a medicina retoma da fisiologia aquilo que ela the forneceu e o que ela mesma recebeu da vida. Pois a 
medicina, como técnica de restauração da saúde, encontra seu solo originário na vida, que já é "atividade médica natural". A própria doença traduz o fato fundamental de que a "vida não é indiferente às condições nas quais ela é possível, que a vida é polaridade e por isso mesmo posição inconsciente de valor, em suma, que a vida é, de fato, uma atividade normativa" (Canguilhem, 1966:77). Pode acontecer que um erro de leitura da mensagem seja a causa das mutações patológicas, assim como dos desvios de estruturas. Então, se as mutações estão na raiz das diferenças que se introduzem na vida, que é conservação de uma informação, por que razão a história das ciências da vida não poderia distinguir, na definição da vida, o que ela tem de permanente, por um lado, e o que ela comporta de ruptura, por outro? Porém, quanto à metáfora segundo a qual o modelo tem pouca importância, Canguilhem afirma que se trata, antes de tudo, de mostrar "em que e como esta história foi realizada". Em A Lógica da Vida, François Jacob assinalava as rupturas, isto é, os diferentes níveis de abordagem do objeto biológico. É com as imagens e as metáforas da normalidade que Canguilhem refaz as ligações destes diferentes níveis. Daí, uma história das ciências bem ajustada ao seu objeto, uma vez que ela esposa a irredutível originalidade dos discursos em sua história. 


\section{Foucault: a história dos saberes e das práticas}

Vera Portocarrero

É porque a filosofia é hoje inteiramente política, e inteiramente histórica. É a política imanente à história e a história indispensável às políticas.

Foucault, 1983

Sem pretender uma abordagem de caráter prescritivo nem soluções para as dificuldades que as pesquisas históricas de Foucault apresentam, tentamos aqui apenas expor a novidade de sua contribuição para os estudos filosóficos e históricos da produção científica.

A delimitação dos objetos tratados por Foucault, que podemos compreender como uma insurreição contra os poderes da 'normalização', corresponde a uma seleção de temas intencionalmente relacionados a pontos muito densos de relações de poder e de produção de saber, como a doença, a criminalidade, a sexualidade, a loucura, o internamento.

Seu objetivo é saber por meio de que jogos de verdade o homem se constitui historicamente como experiência, quando se pensa a si mesmo, ao se perceber como louco, ao se olhar como doente, ao se refletir como ser vivo que fala e que trabalha, ao se julgar criminoso.

Apesar de essencialmente histórica, sua abordagem é, conforme ele mesmo frisa, filosófica e não deve ser confundida com a de um historiador.

São estudos de "história" pelos campos que tratam e pelas referências que assumem; mas não são trabalhos de "historiador" (...) são - se quisermos encará-los do ponto de vista de sua "pragmática" - o protocolo de um exercício que foi longo, hesitante, e que freqüentemente precisou se retomar e se corrigir. Um exercício filosófico: sua articulação foi a de saber em que medida o trabalho de pensar sua própria 
história pode liberar o pensamento daquilo que ele pensa silenciosamente, e permitir-lhe pensar diferentemente (Foucault, 1984:13).

Suas pesquisas são exercícios de uma filosofia comprometida com a mudança, que devem ser mantidas na perspectiva do ensaio, isto é, de uma produção sempre provisória e inacabada. Pois, para Foucault, a filosofia questiona aquilo que em seu próprio pensamento pode ser mudado por meio do exercício com outros saberes, do ensaio.

O ensaio consiste uma "prova modificadora de si", fazendo com que a filosofia não seja uma apresentação simplificadora e unificadora, nem comentário.

\begin{abstract}
Nesta atividade de comentário, que procura transformar um discurso condensado, antigo e como que silencioso a si mesmo, em um outro mais loquaz, ao mesmo tempo mais arcaico e mais contemporâneo, oculta-se uma estranha atitude a respeito da linguagem: comentar é, por definição, admitir um excesso do significado (...) Não seria possível fazer uma análise do discurso que escapasse à fatalidade do comentário, sem supor resto ou excesso no que foi dito, mas apenas o fato de seu aparecimento histórico?(...) Apareceria, então, a história sistemática dos discursos (Foucault, 1977b:XV).
\end{abstract}

Neste sentido, a filosofia não deve consistir em legitimar aquilo que aprendemos por intermédio da ciência, nem em ditar, do exterior, leis aos saberes produzidos, como fazem diversas vertentes da história e da filosofia da ciência, que se baseiam em princípios racionais considerados superiores.

A filosofia consiste em questionar os saberes, articulando-os com as práticas, para compreender as condições de possibilidade de sua existência, sem nenhuma intenção prescritiva.

O Nascimento da Clínica (Foucault, 1977b), por exemplo, obedece a um projeto deliberado de determinar as condições de possibilidade da experiência médica, analisando-as sem colocar uma medicina contra a outra, nem considerar uma ausência de medicina. A intenção é extrair do discurso médico as condições de sua história e não estabelecer uma axiologia, isto é, mostrar a verdade traduzida pelo caráter normativo que deve possuir.

Esta forma de trabalhar com a história da ciência funda-se no seguinte preceito: o que conta nas coisas ditas pelos homens não é tanto o que teriam pensado aquém ou além, mas aquilo que, desde o princípio, as sistematiza, tornando-as indefinidamente acessíveis a novos discursos e abertas à tarefa de transformá-los. 
É difícil e, sobretudo, infecundo sistematizar um pensamento que se formula com o cuidado de, em toda sua trajetória, não se permitir generalizações definitivas. Por esta razão, consideramos mais esclarecedor apenas estabelecer uma certa ordem nos vários deslocamentos conceituais e metodológicos operados por Foucault.

Os primeiros deslocamentos a serem considerados são: da ciência para as práticas discursivas, ou seja, para o saber, realizado em suas pesquisas sobre as "ciências empíricas"; e o deslocamento, realizado por meio do estudo das práticas punitivas, do poder concebido como ideologia para as relações múltiplas de poder, compreendidas como estratégias abertas e técnicas racionais que articulam o seu exercício.

Tal organização parte de um questionamento fundado na relação da filosofia com a história por um lado - história da produção de saberes, cujo objetivo final não é dizer o que pode haver de verdadeiro no conhecimento, mas saber até onde e como é possível pensar de outro modo, que chamaremos História da Verdade $-\mathbf{e}$, por outro lado, na relação da produção de saberes com as relações de poder, que chamaremos Política da Verdade.

\section{UMA HISTÓRIA DA VERDADE}

Ao considerar a questão da história e da filosofia da ciência do ponto de vista de Foucault, é preciso, primeiramente, levar em consideração que seu interesse não diz respeito à ciência propriamente, mas ao saber; não à sua racionalidade imanente, mas às condições externas de possibilidade de sua existência.

É importante notar que, quando nos referimos a saber, estamos compreendendo que se trata de uma categoria metodológica, um recurso instrumental, que significa o nível do discurso e das formulações teóricas, próprios do saber científico ou com pretensão à cientificidade. Mesmo quando não legitimado como ciência, o saber possui uma positividade e obedece a regras de aparecimento, organização e transformação que podemos descrever.

As pesquisas de Foucault se inserem em uma linha da história da verdade determinada pelo espaço teórico, político e institucional dos campos onde se situam os saberes, sem se restringir à ciência.

Não a história das ciências, mas a destes conhecimentos imperfeitos, mal fundados, que nunca puderam atingir, ao longo de uma longa vida obstinada, a forma da cientificidade (Foucault, 1969:179). 
A noção de saber implica poder e história. Cada uma requer, para ser compreendida, que seja remetida à outra. Só explicamos o saber em sua relação de imanência com o poder, e vice-versa. Além disso, só é possivel analisá-los através da história, no sentido da especificidade e singularidade do acontecimento.

Sem dúvida, um dos aspectos mais importantes desta história da verdade é a relação por ele estabelecida entre a produção de verdades e as relações de poder: "a produção de verdade é inteiramente infiltrada pelas relações de poder" (Foucault, 1977a:60).

Não se trata de uma história factual, linear e neutra, que obedeceria aos ideais de descrever os fatos com objetividade total, seguindo uma seqüência causal e cronológica, mas uma história arqueológica e genealógica. Tal história não obedece à noção de uma sucessão progressiva, linear e gradual, mas a continuidades e descontinuidades.

Estas são estabelecidas sem recorrer à idéia de que uma teoria é substituída por uma outra por ser esta última superior, elidindo a questão do progresso, característica da análise histórica que se situa no nível da cientificidade e questiona a maneira pela qual este nível pode ser alcançado a partir de diversas figuras epistemológicas. A proposta de Foucault se afasta do tipo de história da ciência que busca saber como foi possível constituir um domínio científico contra um nível pré-científico.

Pois Foucault considera um mau método colocar a questão "por que progredimos?" O que importa, para ele, é "como isso se passa?" e "(...) o que se passa agora não é forçosamente mais elaborado ou melhor elucidado do que se passou antes" (Foucault, 1982:140).

Em História da Loucura (Foucault, 1972), explicita-se a exigência histórica de desvencilhar as cronologias e as sucessões históricas de toda perspectiva de progresso, em nome de um ceticismo que nos impede a suposição de uma atualidade melhor do que o passado. Isto não deve, no entanto, significar que não devamos reconstituir os processos geradores, mas que o façamos sem thes atribuir uma valoração, uma superioridade hierárquica.

Ao contrário, a questão não é fazer a história da verdade ou das verdades que vão sendo depuradas até atingir um estágio superior em que se alcançasse o saber verdadeiro e neutro. Pois prevalece a afirmação de que todo saber é político; isto é, tem sua gênese ligada a um determinado feixe de relações de poder.

É necessário reconstituir os processos geradores, desde que não o façamos estabelecendo uma axiologia, isto é, que não tentemos interpretá-los em uma linha de progresso em direção a uma verdade cada vez mais afastada dos erros iniciais.

Aliás, Foucault não acredita na verdade. Para ele, a idéia de uma verdade eterna, universal, que está em toda parte e sempre, e que qualquer pessoa pode descobrir, pois está bem próxima à nossa espera, esta idéia é dominante em um sistema de cultura como o nosso. É veiculada pela ciência e pela filosofia. 
Tal idéia deixa de lado uma série de práticas sociais que foram historicamente muito importantes em nossa cultura e que talvez ainda o sejam. Sempre houve, em nossa civilização, instituições, técnicas e rituais que resenvaram momentos e lugares específicos para a produção de verdade não como uma possibilidade mas como um dever. Ou seja, em uma sociedade como a nossa, há um certo número de práticas pelas quais se tenta, não descobrir, constatar ou estabelecer uma verdade que estaria à espera para ser desvendada, mas produzir uma verdade que não existia antes.

A reconstituição a que nos referimos se opõe à história dos comportamentos ou das representações, mesmo quando analisa condutas e idéias, abandonando, por meio da arqueologia, a história das idéias.

\begin{abstract}
Ora, a descrição arqueológica é precisamente o abandono da história das idéias, recusa sistemática de seus postulados e de seus procedimentos, tentativa de fazer uma história completamente diferente daquela que os homens disseram (Foucault, 1969:181).
\end{abstract}

Os dois métodos deste tipo de história da ciência são rejeitados: tanto o da analogia - que segue as vias de difusão no tempo (gêneses, filiações, parentescos, influências) ou na superfície de uma região histórica determinada (o espírito de uma época, suas categorias fundamentais, a organização de seu mundo sociocultural); quanto o método da denegação dos conteúdos (tal século não foi tão racionalista ou irracionalista quanto se pensou etc.), com o qual se inaugura e se desenvolve uma espécie de "psicanálise" dos pensamentos, cujo termo é, de pleno direito, reversível, o núcleo do núcleo sendo sempre o seu contrário.

Afastar-se da história das idéias é tentar escapar do campo da representação, argumentando contra a atribuição de valor superior a determinados códigos éticos ou a certas regras de verdade. É afastar-se da tradição histórica e filosófica, que procura definir quais as verdadeiras regras da conduta do homem e da racionalidade, buscando a verdadeira ética ou a verdadeira ciência.

A proposta de Foucault se restringe à pesquisa dos processos particulares de produção de saber, circunscritos a situações determinadas. Apesar de não ser compreendida em termos gerais e absolutos, a produção de verdade não pode ser tratada na perspectiva de um relativismo, pois, como já dissemos, a verdade é concebida como sendo determinada por efeitos específicos produzidos pelo poder.

Ao negar a história das representações, afirma-se a história das problematizaçōes; pois " afinal, é esta a tarefa de uma história do pensamento por oposição à história dos comportamentos ou das representações: definir as condições nas quais o ser humano "problematiza" o que ele é, e o mundo no qual ele vive" (Foucault, 1984:14). 
A história das problematizações se realiza por uma arqueologia dos saberes e de sua integração a uma genealogia dos poderes, que permite traçar suas práticas. A história arqueológica permite delinear a forma das problematizações por meio da pesquisa do surgimento dos saberes, explicitando o nível do discurso, ao passo que a genealogia remete à prática em que se exercem as relações de poder.

Mas, como essa análise (...) se encontra no ponto de interseção entre uma arqueologia das problematizações e uma genealogia das práticas de si, gostaria de deter-me, antes de começar, nessas duas noções: justificar as formas de "problematização"(...) e substituir uma história dos sistemas de moral (...) por uma história das problematizações éticas, feita a partir das práticas de si (Foucault, 1984:16).

\subsection{A História Arqueológica}

A história arqueológica é um capítulo importante para nossa discussão sobre história e filosofia da ciência exatamente pelo deslocamento da questão da ciência para o saber.

Ao dirigir-se para o domínio do saber, não se restringe mais à descrição de disciplinas ou ciências, mas à descrição de positividades, que abrange os textos literários, filosóficos ou políticos, além de "práticas discursivas".

Em História da Loucura, por exemplo, Foucault estuda o momento em que emerge a psiquiatria, mostrando as condições de possibilidade de seu surgimento, a partir da análise dos saberes e das práticas sobre a loucura, em diferentes épocas, sem se limitar a nenhuma disciplina.

Analisar positividades é mostrar as regras segundo as quais uma prática discursiva pode formar grupos de objetos, conjuntos de enunciações, jogos de conceitos, séries de escolhas teóricas.

Trata-se de estabelecer relações entre os saberes, todos considerados como possuindo uma positividade específica - a positividade do que foi efetivamente dito e deve ser aceito como tal - para que destas relações surjam, em uma mesma época ou em épocas diferentes, compatibilidades e incompatibilidades que permitem individualizar "formações discursivas" e traçar as diversas configurações dos campos de saber.

As positividades não caracterizam formas ou estados de conhecimento. Analisar as positividades é mostrar as regras segundo as quais "práticas discursi- 
vas" podem formar grupos de objetos, conjuntos de enunciados, jogos de conceitos, séries de escolhas teóricas, a partir dos quais se formam proposições coerentes (ou não), desenvolvem-se descrições mais ou menos exatas, efetuam-se verificaçōes que funcionarão como conhecimento ou ilusão, como verdade ou erro.

Desaparece, portanto, o privilégio da verdade científica. O que importa é que todos estes elementos se relacionam a algo que teve de ser - e foi - realmente dito para haver um discurso.

O conjunto dos enunciados efetivos (falados e escritos) constitui um domínio de saber. Estes enunciados são acontecimentos discursivos, cuja descrição permite compreender como foi possível que determinado enunciado aparecesse e outro não.

A análise do campo discursivo toma o enunciado na singularidade do seu acontecimento, para determinar as condições de sua existência, materializada nos manuscritos, livros ou qualquer outra forma de registro contida nos documentos.

Os documentos são a própria materialidade do discurso, e não o signo de outra coisa, como se fosse uma matéria inerte a ser interpretada.
(...) não trata o discurso como documento, como signo de outra coisa, como elemento que deveria ser transparente mas cuja opacidade importuna devemos sempre atravessar para reencontrar enfim, ali onde ela é mantida em segredo, a profundidade do essencial; ela se dirige ao discurso em seu volume próprio, a título de monumento (...) ela não busca um "outro discurso" mais bem escondido. Ela se re- cusa a ser alegórica (Foucault, 1984:10).

Os documentos são as teses, os artigos, os regulamentos e as práticas institucionais que delineiam formas históricas específicas.
(...) a materialidade documentária (livros, textos, receitas, registros, atas, edifícios, instituições, regulamentos, técnicas, objetos, costumes etc.) que apresenta sempre e em toda parte, em toda sociedade, formas ora espontâneas, ora or- ganizadas de remanescências (Foucault, 1984:10).

A história arqueológica funda-se em uma análise do discurso, considerado um conjunto de enunciados que têm seus princípios de regularidade em uma mesma formação discursiva. 
Trata-se de um conjunto finito, de um grupo limitado, circunscrito, de uma seqüência finita de signos verbais que foram efetivamente formulados. $\mathrm{O}$ que interessa à arqueologia não são discursos possíveis, para os quais se estabelecem princípios de verdade ou de validade a serem realizados; ela estuda os discursos reais, que foram efetivamente pronunciados e que se apresentam com uma materialidade.

A intenção desta história é ganhar o nível da prática ao elucidar o surgimento dos saberes que corresponde ao aparecimento de um novo regime no discurso, apontado por meio das descontinuidades, das rupturas.

\begin{abstract}
Pareceu-me que, em certas formas de saber empírico, como a biologia, a economia política, a psiquiatria, a medicina etc., o ritmo das transformações não obedecia aos esquemas suaves e continuistas de desenvolvimento que normalmente se admite. (...) Não são simplesmente novas descobertas; é um novo "regime" no discurso e no saber (Foucault, 1982:3).
\end{abstract}

A novidade da arqueologia é considerar os discursos não como teorias ou abstrações, mas como práticas discursivas, que se relacionam necessariamente com o nível não discursivo. Pois há "saberes que são independentes das ciências", afirma Foucault, "mas não há saber sem uma prática discursiva definida; e toda prática discursiva pode se definir pelo saber que ela forma" (Foucault, 1969:238).

Para haver saber, basta a existência de uma "prática discursiva". A "prática discursiva" é isolada pela arqueologia através da articulação entre os discursos - documentos filosóficos, científicos, literários etc. - e acontecimentos de outra ordem - técnica, social, econômica ou política, que formam séries temporais correspondentes.

Uma formação discursiva (...) coloca o princípio de articulação entre uma série de acontecimentos discursivos e outras séries de acontecimentos, transformações, mutações e processos. Não uma forma intemporal, mas um esquema de correspondência entre várias séries temporais (Foucault, 1969:98).

Tal articulação não se dá em uma linha de causalidade, ou seja, não tenta compreender de que maneira as práticas políticas e econômicas determinam a consciência dos homens e vêm assim influenciar seus discursos. 
Esta articulação é possível devido à relação de imanência entre os discursos e certos princípios de organização dos saberes que podem ser situados como elementos de um dispositivo essencialmente político.

Pois, para Foucault, os saberes devem ser estudados como peças de relações de poder. Daí a necessidade de se trazer, para a compreensão dos saberes do homem, a questão do poder, isto é, seu papel na constituição de novos saberes, da mesma forma que a questão dos saberes, enquanto constituem condições de emergência de novos poderes.

As concepções de verdade, história, positividade e poder são fundamentais para a reflexão sobre o aparecimento dos saberes. O poder será o instrumento capaz de explicar a produção dos saberes, que é produção de verdades, historicamente situada, apresentada em uma dimensão política.

Partindo da análise arqueológica das "práticas discursivas", isto é, do estudo das condições de possibilidade do surgimento e transformação dos saberes, Foucault chega à análise histórica de suas condições políticas - condições externas, porém imanentes ao saber.

Daí a importância da análise dos saberes da "luta" ou saberes "dominados", que são saberes efetivos. Mesmo quando não legitimados pela cientificidade, estes saberes são importantes pois podem ser desvendados em sua verdade, e utilizados contra os efeitos do poder centralizador.

Por esta razão, agrupam-se em uma mesma categoria - a de saber dominado - discursos que não aparecem juntos na tradição filosófica e científica.

\begin{abstract}
Poder-se-ia dizer que existe um estranho paradoxo em querer agrupar em uma mesma categoria de saber dominado os conteúdos do conhecimento histórico, meticuloso, erudito, exato e estes saberes locais, singulares, estes saberes das pessoas que são saberes sem senso comum e foram deixados de lado, quando não foram efetivamente e explicitamente subordinados. Parece-me que, de fato, foi este acoplamento entre saber sem vida da erudição e o saber desqualificado pela hierarquia dos conhecimentos e das ciências que deu à crítica destes últimos anos sua força essencial (Foucault, 1982:170).
\end{abstract}

O Nascimento da Clínica (Foucault, 1977b), por exemplo, é uma análise de discursos que se limita ao fato de seu aparecimento histórico. Aí são enfocados os fatos de discursos, concebidos não como núcleos autônomos de significações múltiplas, mas como acontecimentos e segmentos funcionais formando, pouco a pouco, um sistema. O sentido dos enunciados não é definido pelas in- 
tenções que contém, mas pela diferença que o articula com os outros enunciados reais e possiveis, que the são contemporâneos ou aos quais se opõe na sérle linear do tempo.

Por isto, Foucault pesquisa o saber em sua "dispersividade discursiva", isto é, uma multiplicidade de discursos. Por exemplo, para elaborar a história da sexualidade na modernidade, reúne os discursos da medicina, psiquiatria, biologia, textos religiosos, filosóficos, literários, além do "discurso interno" das instituições, ou seja, daqueles implícitos nas disposições arquitetônicas, nos regulamentos etc.

A crítica do discurso interno das instituições é relevante para a história arqueológica, na medida em que a instituição é um ponto de passagem e de produção de saber e de relações de poder.

Esta "dispersividade discursiva" abrange o saber das "mesquinharias", isto é, das minúcias, que geralmente são desconsideradas; é aquele que aparece no discurso das pessoas em geral, da perícia, dos processos judiciais, dos laudos médicos e psiquiátricos etc.

O historiador não deve temer as mesquinharias, pois foi de mesquinharia em mesquinharia, de pequena em pequena coisa, que finalmente as grandes coisas se formaram. À solenidade da origem é necessário opor, em bom método histórico, a pequenez meticulosa e inconfessável dessas fabricações, dessas invenções (Foucault, 1979:11).

As minúcias referentes ao cotidiano da vida social são importantes para a história arqueológica por se transformarem em elementos de elaboração teórica e de práticas institucionais.

O que é importante nesta história? Seu caráter minúsculo: que o cotidiano da sexualidade aldeã, os ínfimos deleites campestres tenham podido tornar-se, a partir de um certo momento, o objeto não somente de uma intolerância coletiva, mas de uma ação judiciária, de uma intervenção médica, de um atento exame clínico e de toda uma elaboração teórica (Foucault, 1977a:30).

Abordadas a partir da história arqueológica, as práticas discursivas apontam as relações de poder. Considerados como uma série de segmentos descontínuos, cuja função tática não é uniforme nem estável, os discursos veiculam, produzem, reforçam ou debilitam o poder.

Nos discursos, podemos analisar as correlações de forças codificadas. É justamente neles que poder e saber se articulam. Para Foucault, o discurso é o limite, ou melhor, o ponto de interseção entre saber e poder. 
O que interessa na análise do discurso é questionar, por um lado, sua produtividade tática, isto é, que efeitos recíprocos de poder e saber proporciona; por outro, sua integração estratégica, ou seja, que conjuntura e que correlações de forças tornam necessária sua utilização nos confrontos produzidos na vida concreta.

A arqueologia responde à questão "como?" os saberes emergem e se transformam, a partir da constituição de novos saberes, privilegiando as interrelações discursivas e sua articulação com as práticas institucionais - família, igreja, justiça, hospital etc. A genealogia completará esta análise, tentando responder à questão do "porquê" dos saberes, da "origem" de sua existência e de suas transformações, situando-os como peças de relações de poder ou como dispositivo político de natureza essencialmente estratégica.

\subsection{A História Genealógica}

A genealogia trata da questão do poder em sua relação com o saber; o poder gera saberes e o saber gera poderes. Na história genealógica, esta relação é radicalizada: somos submetidos pelo poder à produção da verdade e só podemos exercê-lo por meio dela.

A história genealógica não apresenta um método sistemático. Aliás, nem a história genealógica nem a arqueológica apresentam um "método" no sentido mais freqüente do termo. Discutem hipóteses ou referem-se a precauções metodológicas, consideradas prescrições de prudência, precauções metodológicas que não são, propriamente, imperativos metodológicos.

Tais prescrições são regras instrumentais que servem de direcionamento para as reflexões; não se colocam previamente à pesquisa, mas no seu desenrolar mesmo, com base nos documentos encontrados.

A genealogia é uma das duas dimensões das pesquisas de Foucault; a outra é, como já vimos, a arqueologia. A dimensão arqueológica permite escapar da noção de ciência como representação e do dilema ciência-ideologia (ciência como lugar da verdade, ideologia como lugar do poder e do erro) ao utilizar a categoria metodológica de saber e acompanhar sua formação, sua manifestação e suas transformações; a dimensão genealógica possibilita escapar da noção do poder como representação correlata de uma entidade.

O trabalho que empreendi anteriormente (...) deu-me os instrumentos dos quais necessitava; a análise das práticas discursivas permitia seguir a formação dos saberes, escapando ao dilema entre ciência e ideologia; a análise das relaçóes 
de poder e de suas tecnologias permitia focalizá-las como estratégias abertas, escapando à alternativa entre um poder concebido como dominação ou denunciado como simulacro (Foucault, 1984:15).

Do mesmo modo que a arqueologia, a história genealógica se insere na linha da história da verdade, analisando problematizações, não idéias ou comportamentos.

\begin{abstract}
Parece-me que seria melhor perceber, agora, de que maneira, um tanto cegamente, e por meio de fragmentos sucessivos e diferentes, eu me conduzi nessa empreitada de uma história da verdade: analisar não os comportamentos, nem as idéias, não as sociedades nem suas ideologias, mas as problematizações através das quais o ser se dá como podendo e devendo ser pensado, e as práticas a partir das quais essas problematizações se formam (Foucault, 1984:15).
\end{abstract}

Trata-se, conforme apontado na introdução, mais especificamente: primeiro, da problematização da loucura, da doença e da sexualidade, a partir de práticas médicas e sociais que definem um certo perfil de "normalização" - sendo a normalização um tema amplamente discutido por Foucault; segundo, da problematização da vida, da linguagem e do trabalho por meio da análise das práticas discursivas, obedecendo a certas regras epistêmicas, conforme analisa em As Palavras e as Coisas (Foucault, 1966); terceiro, da problematização do crime e do comportamento criminoso, a partir de certas práticas punitivas, obedecendo a um modelo disciplinar.

As problematizações constituem o objeto da história genealógica tanto do ponto de vista do pensamento, da forma pela qual são pensadas, como do ponto de vista da prática, da maneira como são vivenciadas. Elas são abordadas tanto quanto à sua forma como quanto às suas modificações.

A reconstrução genealógica critica a verdade do ponto de vista dos "jogos de verdade", isto é, das relações entre o verdadeiro e o falso, que se produzem como efeitos de poder. Ao ser concebida como discurso produzido pelo poder, a verdade só pode ser pensada no interior desta relação.

O importante, creio, é que a verdade não existe fora do poder ou sem poder (não é - não obstante um mito, de que seria necessário esclarecer a história e as funções - a recompensa dos espíritos livres (...) (Foucault, 1984:12). 
Pois a verdade é política e cada sociedade tem seu regime de verdade, sua "política geral" da verdade; isto é, os tipos de discurso que acolhe e faz funcionar como verdadeiros, os mecanismos e as instâncias que permitem distinguir os enunciados verdadeiros dos falsos, a maneira como se sancionam uns e outros, as técnicas e os procedimentos que são valorizados para a obtenção da verdade; o estatuto daqueles que têm o encargo de dizer o que funciona como verdadeiro.

No cerne do conhecimento, sempre encontramos a luta, as relações de poder que conferem ao conhecimento um caráter de distância e de dominação e não de adequação, beatitude ou unidade, buscadas pela tradição filosófica. A verdade é estratégica; uma luta pelo controle e pela vitória.

\section{UMA POLÍTICA DA VERDADE}

Em suas análises, Foucault procede à elaboração de uma história da verdade que ele mesmo denomina "política da verdade". Trata-se de mostrar o caráter eminentemente político da produção de verdade, ou melhor, de considerar as condições políticas como constitutivas do conhecimento; são elementos fundamentais para a história dos saberes e não um véu ou um obstáculo.

A história genealógica aborda os discursos de verdade, atribuindo-lhes um caráter estratégico. Para Foucault, o conhecimento é uma relação estratégica em que o homem se situa para se constituir como sujeito cognitivo. Daí o caráter perspectivo do conhecimento, isto é, de sua constituição como estratégia de dominação e de luta, segundo a qual só há conhecimento na medida em que se estabelece um confronto, um duelo entre o homem e o objeto. Ao fazê-lo, Foucault nega a possibilidade da neutralidade do conhecimento, afirmando sua parcialidade.

O conhecimento é sempre uma certa relação estratégica em que o homem se encontra situado. É essa relação estratégica que vai definir o efeito de conhecimento e por isso seria totalmente contraditório imaginar um conhecimento que não fosse em sua natureza obrigatoriamente parcial, oblíquo, perspectivo (Foucault, 1984:19).

De acordo com este ponto de vista, mesmo na ciência existem modelos de verdade formulados pela relação do saber com as estruturas políticas. Contudo, tais estruturas não podem ser compreendidas como impostas do exterior ao sujeito do conhecimento, uma vez que o poder lhe é imanente. 
A noção de "política da verdade" se opõe às teorias generalizadoras do poder e da verdade, ao investigar os mecanismos das regras que delimitam formalmente o poder e os efeitos específicos de verdade que ele produz e transmite.

Para tal, Foucault elabora uma "analítica do poder", com base em uma concepção de poder que o descreve como um conjunto de realidades abertas, mais ou menos coordenadas, que não nos permitem descrevê-lo como alguma coisa dada, sobre a qual pudéssemos fazer deduções.

Ao contrário, para compreendermos o poder, precisamos estabelecer estrategicamente uma rede de análise que possibilite a "analítica" das relações de poder e sua relação com a verdade.

Pois vivemos em uma sociedade que caminha "ao compasso da verdade" (Foucault, 1982:231), ou seja, que produz e faz circular discursos que funcionam como verdade, e que por isso representam poderes específicos. Um dos principais problemas da civilização ocidental é a produção de discursos "verdadeiros", que, por sinal, mudam sempre. Foucault examina o poder próprio aos discursos aceitos como verdadeiros através da história genealógica.

A História da Sexualidade I (Foucault, 1977a), que integra o projeto da arqueologia ao da genealogia, é uma tentativa de mostrar a relação, nas sociedades ocidentais contemporâneas, entre o sexo, a procura da verdade, e o poder.

Seu ponto de partida é a seguinte questão: como é possível que a sexualidade tenha sido considerada o lugar privilegiado em que nossa "verdade" profunda pode ser encontrada, ao invés de se apresentar simplesmente como aquilo que permite a reprodução da espécie ou o que proporciona prazer?

Foucault afirma, que, em nossa sociedade, o sexo transformou-se em algo que era preciso ser examinado, vigiado, confessado, transformado em discurso, para interferir na realidade das instituições e das práticas. Além disso, suscitou proibições que fazem parte de uma economia complexa, onde as repressões coexistem com incitações, manifestações e valorizações.

Esta questão já aparece em História da Loucura (Foucault, 1972), quando se afirma que a maneira pela qual o poder que se exerce sobre a loucura produziu o discurso "verdadeiro" da psiquiatria, e, em História da Sexualidade I, quando se pergunta como é que se constituiu uma vontade de saber, onde o poder se imiscuiu, por meio do dispositivo da sexualidade.

A genealogia parece a história das proibições e do poder repressivo, apresentada bipolarmente: a loucura e seu enclausuramento, a anomalia e sua exclusão, a delinqüência e seu aprisionamento. Mas sua questão central está em outro pólo, o da verdade, na busca do conjunto de dispositivos que esclarecem a produção de verdade. 
Ora, meu problema sempre esteve do lado de um outro pólo: a verdade (...) Não quero fazer a sociologia histórica de uma proibição, mas a história política de uma produção de verdade (Foucault, 1982:230).

\subsection{Verdade e Poder}

Ao pensar a questão do poder em sua relação com a verdade, Foucault substitui a questão tradicional da filosofia política - como pode o discurso da verdade fixar os limites de direito do poder? - por outra questão que considera mais elementar e mais concreta: de que regras de direito as relações de poder lançam mão para produzir discursos de verdade, em uma sociedade como a nossa; que tipo de poder é capaz de produzir discursos de verdade dotados de efeitos tão poderosos - no nível da prática institucionalizada e do discurso, do saber.

A análise do nascimento das ciências do homem faz corresponder a origem do saber à instauração de novos mecanismos de poder. A ciência produz "verdades" às quais nos submetemos; a verdade é, sem dúvida, uma forma de poder.

Foucault nos adverte do perigo desta forma de dominação. Para ele, não há nada mais tirânico e fatal do que colocar sua vida, seus desejos ou sua sexualidade sob o signo de uma ciência ou de uma ideologia, ou melhor, de uma petição de verdade; e o papel do saber não é apenas a produção de verdade, mas o exercício de poder.

Daí o questionamento da relação entre as ciências - ou, antes, os saberes - e os mecanismos econômicos e políticos de nossa sociedade. Para ele, perguntar a uma ciência, como a física teórica ou a química orgânica, quais as suas relações com as estruturas políticas e econômicas, seria uma exigência de explicação certamente mal encaminhada.

Porém, colocar esta pergunta para as ciências do homem, a psiquiatria, por exemplo, é ter uma questão necessariamente enriquecedora, na medida em que, do ponto de vista epistemológico, o perfil destas ciências é pouco definido, e suas práticas se inserem em instituições obviamente ligadas a exigências econômicas e políticas, profundamente enraizadas nas estruturas sociais, como é o caso do asilo psiquiátrico.

Saber e poder não são opostos, aparecerão sempre interligados em uma relação caracterizada pelo fato de que o poder e o saber funcionam em uma relação de correlação e não de causalidade. Por este motivo, precisamos determinar sua especificidade histórica. 
Poder e saber não são redutíveis um ao outro. Foucault não tenta fazer do saber uma simples base hipotética, nem conceitualiza o poder como uma estratégia invariavelmente coerente. Ele tenta mostrar a especificidade e o caráter concreto das relaçóes de poder e saber.

Tal análise obedece a certas precauções metodológicas: ao invés de tomar o poder no sentido de sua catalisação nos aparelhos de Estado e nas ideologias que o acompanham, a história genealógica dirige-se para a dominação, os operadores materiais, as formas de sujeição, os usos e as conexões da sujeição pelos sistemas locais e os dispositivos estratégicos.

Tradicionalmente, o saber é o lugar da verdade e da liberdade, ao passo que o poder é a repressão, a interdição, o mal pertenceriam, portanto, a regiões que não se misturam.

\begin{abstract}
A confissão libera, o poder reduz ao silêncio; a verdade não pertence à ordem do poder mas tem um parentesco originário com a liberdade: eis aí alguns temas tradicionais da filosofia que uma "história política da verdade" deveria resolver, mostrando que nem a verdade é livre por natureza, nem o erro é servo: que sua produção é inteiramente infiltrada pelas relações de poder (Foucault, 1977a:60).
\end{abstract}

Porém, de acordo com Foucault, a verdade é produzida graças a múltiplas coerções e produz efeitos regulamentados de poder. As relações de poder são muito mais complexas e sua explicação não pode se limitar à sua função negativa, repressiva. Ou seja, o conceito de poder como repressão é insuficiente.

Ele explica: nas sociedades capitalistas o poder é negativo e repressivo, porém possui uma eficácia produtiva e uma positividade que precisa ser conhecida; a positividade da gestão da vida dos indivíduos e das sociedades, para a qual produz uma série de saberes específicos, capazes de auxiliar na função de tornar os indivíduos dóceis, do ponto de vista político, e produtivos, do ponto de vista econômico.

Em uma sociedade como a nossa não há o poder, mas múltiplas relações de poder que a atravessam, caracterizando e constituindo o corpo social; e estas relações não podem se dissociar, se estabelecer, nem funcionar sem produção, acumulação, circulação e funcionamento do discurso de verdade: "Não há possibilidade de exercício de poder sem uma certa economia dos discursos de verdade" (Foucault, 1982:179). Ademais, somos obrigados pelo poder a produzir, confessar ou encontrar a verdade; é como produzir riquezas. 
No fundo, temos que produzir a verdade como temos que produzir riquezas, ou melhor, temos que produzir a verdade para poder produzir riquezas. Por outro lado, estamos submetidos à verdade também no sentido em que ela é lei e produz o discurso verdadeiro que decide, transmite e reproduz, ao menos em parte, efeitos de poder. Afinal, somos julgados, condenados, classificados, obrigados a desempenhar tarefas e destinados a um certo modo de viver ou morrer, em função dos discursos verdadeiros que trazem consigo efeitos específicos de poder (Foucault, 1982:179).

A questão da genealogia, então, é: o que é o poder? Mais precisamente: como se exerce, como acontece que alguém exerça um poder sobre outra pessoa?

Segundo Foucault, a maneira como o poder se exerce em uma sociedade como a nossa é muito mal conhecida. Nem as generalizações marxistas, concernentes à dominação da classe burguesa, dão totalmente conta desta questão. Até porque nos resta saber como o poder se exerce. Mesmo que consigamos apontar os responsáveis pelas decisões, resta, ainda, pesquisar como e por que elas foram tomadas, como puderam ser aceitas por todos e de que maneira ferem determinada categoria de pessoas.

Desta forma, Foucault dirige suas análises sobre as relações de poder para o estudo das estratégias de poder, isto é, os feixes, os mecanismos, toda a técnica que faz com que uma decisão seja aceita, e com que não pudesse ter sido tomada de outra forma.

A questão central da genealogia é, sem dúvida, o poder. Mas não no sentido de determinar um conceito de poder. É, antes, a questão do exercício do poder. $\mathrm{O}$ poder deve ser analisado como uma rede de relações múltiplas que se exercem em todos os segmentos da sociedade.

Neste sentido, o poder não pode ser confundido com Estado, que não é seu único portador, nem seu aparelho exclusivo. Toda sociedade é vazada por micropoderes locais, específicos, circunscritos a uma pequena área de ação. Há uma multiplicidade de formas de exercício de poder, diferentes do Estado, a ele articuladas de maneiras indispensáveis à sua ação.

Foucault mostra uma diferença entre as grandes transformações do sistema estatal, por exemplo, as mudanças de regime e a mecânica do poder, que se expande por toda sociedade, assumindo formas regionais e concretas, investindo em instituições, tomando corpo em técnicas de dominação.

$O$ aparelho do Estado é um instrumento específico de um sistema de poderes que o ultrapassa e o complementa. Por esta razão, nem o controle, nem a destruição do aparelho de Estado, como muitas vezes se pensa, são suficientes para fazer desaparecer ou transformar, em suas características fundamen- 
tais, a rede de poderes, em uma sociedade. Não se trata, contudo, de minimizar o papel do Estado, mas de reconhecer que este não é o único órgão de poder efetivo.

Para dar conta da análise dos diversos mecanismos de poder, a genealogia estuda os poderes específicos - os mecanismos e as técnicas relacionados à produção de determinados saberes sobre o criminoso, a sexualidade, o louco, a doença etc.; a finalidade é ver como estes poderes específicos, estes micropoderes, que têm tecnologia e história próprias, se relacionam com o Estado.

Cabe ressaltar que os poderes não estão situados em nenhum ponto particular da estrutura social; eles estão em toda parte. Eles funcionam através de uma rede de dispositivos interdependentes.

O poder se define pelos mecanismos de resistência, ou melhor, pelo caráter estritamente relacional das correlações de força, que só existem em função de uma multiplicidade de pontos de resistência que representam, nas relações de poder, o papel de adversário, de alvo, de apoio, de saliência. Estes pontos perpassam toda a rede de poder.
(...) lá, onde há poder, há resistência e, no entanto (ou melhor, por isto mesmo), esta nunca se encontra em posição de exterioridade em relação ao poder (Foucault, 1977a:91).

Não há um foco de rebelião, um lugar de revolta, mas multiplicidade de resistências, que são casos únicos, diferentes entre si, presentes em toda a rede de poder.

\begin{abstract}
Esses pontos de resistência estão presentes em toda a rede de poder. Portanto, não existe, com respeito ao poder, um lugar da grande recusa - alma da revolta, foco de todas as rebeliōes, lei pura do revolucionário. Mas sim resistências, no plural, que são casos únicos: possíveis, necessárias, improváveis, espontâneas, selvagens, solitárias, planejadas, arrastadas, violentas, irreconciliáveis, prontas ao compromisso, interessadas ou fadadas ao sacrifício; por definição não podem existir a não ser no campo estratégico das relações de poder (Foucault, 1977a:91).
\end{abstract}

As resistências não são simples reações à dominação, "elas são o outro termo nas relações de poder"; são seu interlocutor irredutível (Foucault, 1977a:91). São pontos móveis e transitórios que rompem unidades, suscitam reagrupamen- 
tos, percorrem os próprios indivíduos e as estratificações sociais, formando um tecido que atravessa as estratificações sociais, do mesmo modo que a rede de relações de poder atravessa os aparelhos e as instituições.

Da mesma forma que a rede das relações de poder acaba formando um tecido espesso que atravessa os aparethos e as instituições, sem se localizar exatamente neles, também a pulverizaçăo dos pontos de resistência atravessa as estratificações sociais e as unidades individuais (Foucault, 1977a:91).

É no campo das múltiplas correlações de força que, segundo Foucault, devemos tentar analisar os mecanismos de poder, negando a oposição binária simplificadora entre dominantes e dominados.

\subsection{O Poder Disciplinar e o Biopoder}

Em História da Sexualidade I, Foucault descreve as práticas de nossa época como sendo o produto de uma confluência de tecnologias desenvolvidas para racionalizar a polícia das populações - é isto que define como "biopoder".

O projeto de Foucault em relação à questão do poder é desembaraçar-se de uma representação jurídica e negativa do poder, caso em que poder significa apenas lei, interdição, soberania, negação de liberdade. Ele assume uma outra chave de interpretação histórica: o caráter da positividade, da produtividade do poder e não o da escassez ou da repressão.

Considerado em linhas gerais, o poder é uma rede de relações que se exercem em todos os segmentos da sociedade. Não é generalizável, nem personalizável. Toda sociedade é vazada por micropoderes que são poderes locais, específicos, circunscritos a uma determinada área de ação; são práticas ou correlações de forças que possuem uma eficácia produtiva para gerar a vida dos indivíduos e regular as populações.

Nas sociedades contemporâneas ocidentais, as relações de poder assumem formas regionais e concretas com o objetivo de fazer do indivíduo e da população entidades saudáveis, normais e produtivas, por meio da norma e da sujeição à força da disciplina.

O poder "disciplinar" atinge a realidade mais concreta do indivíduo - seu corpo, com táticas específicas que visam a maximizar sua docilidade e utilidade, ordenando as multiplicidades humanas. 
De maneira global, pode-se dizer que as disciplinas são técnicas para assegurar a ordenação das multiplicidades humanas. É verdade que não há nisso nada de excepcional, nem mesmo de característico: a todo sistema de poder se coloca o mesmo problema. Mas o próprio das disciplinas é o que elas tentam definir, em relação às multiplicidades, uma tática de poder que responde a três critérios: tornar o exercício do poder o menos custoso possível (economicamente, pela baixa despesa que acarreta; politicamente, por sua discreção, sua fraca exteriorização, sua relativa invisibilidade, a pequena resistência que suscita); fazer com que os efeitos deste poder social sejam levados a seu máximo de intensidade e estendidos tão longe quanto possível, sem fracasso nem lacuna; ligar, enfim, este crescimento "econômico" do poder e a produção dos aparelhos no interior dos quais ele se exerce (sejam os aparelhos pedagógicos, militares, industriais, médicos), em suma, fazem crescer ao mesmo tempo a docilidade e a utilidade de todos os elementos do sistema" (Foucault, 1975:219).

A disciplina ajuda a fazer funcionarem as relações de poder, da maneira mais discreta e mais econômica possível, por meio de poderes anônimos, exercidos pelos regimentos, pela vigilância hierárquica, pelo registro contínuo, pelo exame e pela classificação. Seu principal objetivo é assegurar a regulação do corpo social inteiro. Seu projeto é criar uma sociedade sadia, propondo a produção de um novo tipo de indivíduo e de população - normal - necessários à existência e manutenção da sociedade capitalista.

O projeto de criar uma sociedade sadia e estabelecer uma economia social esteve sempre ligado ao projeto de transformação do desviante - mendigo, louco, entre outros - em indivíduo normalizado. Dessa forma, tenta-se tornar a pobreza útil, ou pelo menos aliviar ao máximo seu peso para o resto da sociedade, delineando-se, assim, uma decomposição utilitária da pobreza. $\mathrm{O}$ problema específico da doença e da necessidade de produção, e a idéia do bem-estar físico e moral da população passam a estar intrinsecamente ligados à utilidade dos indivíduos, sendo, então, os corpos considerados economicamente vantajosos e politicamente úteis.

O modelo arquitetural de Bentham (Bentham, 1977) esclarece os princípios do poder disciplinar, cuja base fundamental é o princípio do panoptismo que, conforme indica o próprio significado da palavra, é o princípio da total visibilidade. 
(...) Na periferia, uma contrução em anel; no centro, uma torre; esta com grandes janelas que se abrem para a face interna do anel; a construção periférica é dividida em celas, e cada uma atravessa toda a espessura da construção; as celas têm duas janelas, uma para o interior, que corresponde às janelas da torre; a outra dando para o exterior, permite que a luz atravesse a cela de fora a fora. Basta, então, colocar um vigilante na torre central, e em cada cela fechar um louco, um doente, um condenado, um operário ou estudante (Foucault, 1975:201).

O Panopticon "é o diagrama de um mecanismo de poder reduzido à sua forma ideal; seu funcionamento, abstraído de todo obstáculo, resistência ou choque, pode ser representado como um puro sistema arquitetônico e ótico: é de fato uma figura de tecnologia política que se pode e deve desligar de qualquer uso específico. Ele é polivalente em suas aplicações" (Foucault apud Machado, 1990:213).

O Panopticon é explicado pela fórmula "ver sem ser visto" - garantida pela disposição arquitetônica -, salientando-se a importância da vigilância hierárquica como um instrumento do poder disciplinar ou de um dispositivo que age pelo efeito de uma visibilidade geral ou coage pelo jogo do olhar.

A constituição do saber pelo exemplo de instituições, em que o exercício do poder é singularizado e especificado, aparece na obra de Foucault quando ele assinala a importância do exame como procedimento disciplinar: o hospital como aparelho de examinar permitiu o desbloqueio da medicina moderna; a escola examinatória, o nascimento da pedagogia "científica"; a prisão, a formação de um "saber clínico sobre os condenados" (Machado, 1990:213).

A prática do poder é irredutível à prática do saber porque o poder é uma prática informe, difusa, instável, móvel. Os dois exemplos dados por Foucault são: o panóptico e a governamentalidade, definida como a função de "gerir e controlar a vida em uma multiplicidade qualquer, à condição de que a multiplicidade seja numerosa (população) e o espaço aberto ou extenso" (Foucault apud Machado, 1990:92).

Foucault explicita a relevância da questão da governamentalidade, historicamente incrementada a partir do momento em que a população passou a ser compreendida como problema econômico e político; quando os governos percebem que não têm de lidar apenas com sujeitos ou povos, mas com uma população que tem variáveis específicas: natalidade, mortalidade, fecundidade, saúde, doença etc. 
Estas variáveis se situam no ponto de interseçăo entre os movimentos próprios à vida e os efeitos particulares das instituições. Governar implicará, então, produzir e recorrer a novas tecnologias e a saberes que auxiliem na função de gerir a vida dos indivíduos e das populaçōes.

Neste sentido, a população encontra-se submetida a uma organização adequada, administrada pelo poder do Estado, direcionada para o bem dos indivíduos, por meio da regulação do corpo social em todos os seus aspectos.

Bentham propõe o panoptismo como a tecnologia capaz de fazer essa regulação. A regulação do corpo social inteiro seria obtida através da distribuição dos indivíduos em uma organização panóptica, reforçada pela disciplina e pelas instituições.

Daí as análises feitas por Foucault das instituições de enclausuramento. No exército, na escola, no hospital, na prisão, no hospício, a tecnologia de controle é a mesma.

Contudo, o poder disciplinar não pode ser identificado a uma instituição nem a um aparelho porque é um tipo de poder, uma tecnologia, uma modalidade de poder encontrada em instituições de natureza e objetivos bastante diferentes. A disciplina é compreendida como um elemento ou uma técnica comum essencial às diferentes instituições.

Em Vigiar e Punir, assim como em História da Sexualidade, evidencia-se o funcionamento específico das normas modernas, definidas como um processo de normalização. A normalização desempenha um papel capital no leque de técnicas, práticas, saberes e discursos de nossa época. Evidentemente cada sociedade possui suas próprias normas e define as relações sociais em função delas.

Porém, para Foucault, as normas de nossa sociedade e os métodos de socializaçāo que empregamos são, em geral, especialmente perigosos. Ele chama nossa atenção sobre esta especificidade perturbadora, a saber, que as normas, às quais nossa sociedade se refere, funcionam segundo um tipo particular de estratégia direta - "uma estratégia sem estrategista".

Tais normas visam a integrar todos os aspectos de nossas práticas em um todo coerente, em nome de que diversas experiências são isoladas e anexadas como domínios apropriados de estudo teórico e de intervenção. No interior destes domínios, as normas não são estáticas, mas se ramificam a fim de colonizar, nos seus mínimos detalhes, as micropráticas, de modo que nenhuma ação considerada importante delas escape. As práticas normalizadoras definem, a priori, o padrão de normalidade, para depois, então, isolar e tratar as anomalias em função desta definição.

É este tipo de normatividade que caracteriza as normas de nossa sociedade. As normas tendem a uma especificação e a uma totalização cada vez maiores, submetendo-se ao crivo da razão para esclarecer a verdade profunda da consciência que temos de nós mesmos e de nossa cultura. 


\section{CONSIDERAÇÕES FINAIS}

Há diversas possibilidades de compreender as contribuições do pensamento de Foucault para a história e a filosofia da ciência: por exemplo, percorrer os resultados objetivos de suas pesquisas históricas (como se deu o nascimento da clínica, qual a história da nossa sexualidade, com que marcos cronológicos ele trabalhou, como e quando surgiu a biologia etc); ou percorrer os caminhos traçados no sentido da metodologia, apontando a fundamentação filosófica com que conduziu as questões de maior relevo em sua obra. Escolhemos a segunda forma de abordagem, sem, contudo, Ihe conferir um caráter normativo nem de sistematização de regras metodológicas, conforme afirmamos inicialmente.

Sem dúvida, entender os deslocamentos conceituais e metodológicos aqui apontados é uma tarefa indispensável. Tais deslocamentos oferecem um meio de nos introduzirmos em questões de fundo que constituem o atual debate entre epistemólogos, historiadores e sociólogos da ciência.

As questões relativas às concepções de verdade, história e poder, nos permitem, conforme vimos, falar de uma história da verdade e de uma política da verdade. Sua relevância para este debate reside no fato de serem fundadas em uma proposta de ganhar o nível da prática, por meio de uma análise do saber e de uma "analítica" do poder que partem da busca de suas positividades, entendidas não no sentido ético ou axiológico, mas como produtividade.

Procuramos mostrar a forma pela qual Foucault construiu sua abordagem histórico-filosófica sem tentar solucionar as dificuldades a ela implícitas, nem explicitar seus interlocutores, o que teria sido certamente importante.

Deixamos estas tarefas e outras mais para o leitor interessado. 


\section{Kuhn: o normal e \\ o revolucionário na reprodução da racionalidade científica}

Alberto Oliva

\section{KUHN E O DISCURSO EPISTEMOLÓGICO TRADICIONAL}

$\mathrm{T}$

Thomas Kuhn ficou bastante conhecido entre nós por sua obra The Structure of Scientific Revolutions (1970). Aliás, esse seu livro de 1962 é o grande best-seller da história da epistemologia. Sua lenta gestação, envolvendo quase quinze anos de intenso trabalho, representou a gradual metamorfose do físico no historiador da ciência. Malgrado toda a importância de sua reflexão para a filosofia da ciência, Kuhn prefere se apresentar como um historiador da ciência: "Sou membro da American Historical Association e não da American Philosophical Association" (Kuhn, 1977b:11). Em franca discordância com a tradição epistemológica ${ }^{1}$, ele não se limita a ver na história da ciência uma fonte de exemplos respaldadores ou refutadores de posições metodológicas previamente tomadas. Para Kuhn, o estudo da história nos faria ver a ciência de um modo diferente daquele que é ensinada e daquele veiculado pelas reconstruções lógicas oferecidas nos tratados sobre método científico. Em suma, a história da ciência se mostraria geradora de problemas especiais para efeito de reconstrução da racionalidade científica.

A etapa decisiva de elaboração de seu The Structure of Scientific Revolutions transcorreu quando da estada de Kuhn no Center for Study in the Behavioral Sciences (1958-9). De sólida formação em física, Kuhn ficou particularmente impressionado com os combates epistemológicos aí travados por cientistas sociais, em torno de questões e procedimentos basilares. Chamaram-lhe a atenção

1 À diferença da esmagadora maioria dos filósofos anglo-americanos da ciência, Kuhn sofreu forte influência da epistemologia francesa. Chegou a considerar Alexandre Koyré seu verdadeiro maître (Kuhn, 1977b: 21). 
o número e a extensão dos desacordos entre os cientistas sociais. Debatiam-se desde os critérios que devem ser adotados para a escolha dos problemas reputados legítimos até a eleição do método capaz de gerar sistemas explicativos plenamente justificáveis. Por mais que constatasse a existência de controvérsias em astronomia, física, química, biologia etc., nada se comparava à Methodenstreit - à querela do método -, endêmica nas ciências sociais. E como era fácil constatar que as disputas sobre o básico não decorriam do fato de os cientistas sociais, à diferença dos naturais, não saberem caracterizar convenientemente método científico, Kuhn passa a investigar donde promanariam diferenças tão gritantes quanto aos modos de caracterizar e conduzir cursos específicos de pesquisa.

Se os cientistas naturais não dispõem, como pensa Kuhn, de uma concepção de método consensualmente endossada - ou até explícita e sistematicamente articulada - mas desenvolvem procedimentos de pesquisa convergentes, a que atribuir a flagrante diferença com a prática teórica das ciências sociais? Não constitui exagero dizer que Kuhn desenvolve sua obra epistemológica como uma engenhosa tentativa de fazer frente a esse problema. Por se assumir como um historiador da ciência e por ter afastado a possibilidade de as diferenças entre ciências naturais e sociais poderem ser creditadas a razões metodológicas stricto sensu, Kuhn buscará localizar causas que, em sua maioria, não pertencem ao campo tradicionalmente demarcado como o da epistemologia. À diferença do que vinha historicamente fazendo a filosofia da ciência, não se deve esperar encontrar em Kuhn um conjunto de cânones metodológicos capazes de conferir, desde que cuidadosamente seguidos, cientificidade a um saber. Não se trata, assim, de pretender oferecer procedimentos de justificação supostamente superiores aos que vinham sendo recomendados pela tradição epistemológica. Isto torna difícil fazer um enquadramento rigoroso das formulações kuhnianas. Afinal, são simultaneamente apresentadas como extraídas da história da ciência, como capazes de aprender reconstrutivamente o papel cumprido por fatores psicossociais na (re)produção da racionalidade científica e como prenhes de conseqüências epistemológicas:

Muitas das minhas generalizações concernem à sociologia ou à psicologia social dos cientistas. No entanto, pelo menos algumas das minhas conclusões pertencem ao que tradicionalmente se convencionou chamar Lógica ou Epistemologia. (Kuhn, 1970:70)

É ambicioso o projeto kuhniano: ir da história da ciência para a epistemologia passando por generalizações sobre as condições psicossociais que tornam possível o fazer ciência. Daí conferir destaque à seguinte questão: é a comunidade especial que congrega os cientistas, que dá unidade mínima às atividades de seus praticantes ou é a existência de um método, ainda que tacitamente com- 
partilhado, que gera a identidade peculiar dessa comunidade? Seu modo de respondê-la corresponde à busca dos pontos de interação entre as razões epistêmicas tradicionais e os fatores psicossociais que se fazem presentes no processo de reprodução da racionalidade científica.

As correntes epistemológicas clássicas têm almejado descrever os procedimentos estandardizados empregados pelos pesquisadores ou prescrever outros, pretensamente superiores aos utilizados, com vistas a identificarem ou normatizarem o que é singular na racionalidade científica. O descritivismo costuma invocar períodos decisivos do desenvolvimento de certas ciências para transformar as máximas comportamentais aí seguidas em cânones metodológicos para toda e qualquer investigação científica. É claro que o descritivismo não se propõe a fazer um levantamento exaustivo de todas as possiveis formas até aqui adotadas de condução da pesquisa científica. Limita-se a observar momentos reputados decisivos, para em seguida generalizar o que foi aí constatado, como se fossem universais e inevitáveis os procedimentos básicos aí identificados. Consoante o descritivismo tradicional, a história da ciência deve ser estudada com o objetivo de proporcionar evidência favorável a uma determinada perspectiva epistemológica. Não há, nesse caso, a preocupação que se mostrará fundamental no descritivismo kuhniano, de tentar, com base em exemplos históricos, alargar o conceito de racionalidade científica de modo a abrigar fatores que tradicionalmente tinham sido vistos como objetos de investigação ou bem da sociologia da ciência ou bem da psicologia da descoberta. Kuhn não está interessado em endossar as rígidas linhas divisórias entre o domínio voltado para a lógica da pesquisa científica e o campo preocupado com os fatores psicossociais que se fazem universalmente presentes nos diferentes cursos de pesquisa.

Não querendo endossar velhas e rígidas contraposições entre razões lógico-empíricas e fatores psicossociais, Kuhn dá a impressão de que sua reflexão partiu da seguinte questão: os rituais de justificação que têm sido propostos em metaciência configuram inevitabilidades lógicas ou têm sua identidade, ao menos em parte, derivada de idealizações aprioristas insensíveis a fatores extrajustificacionais? ${ }^{2}$ Até que ponto não é, pergunta-se o autor, a espartana pedagogia a

2 Poderia um defensor da epistemologia tradicional sustentar que, em virtude da patente assimetria entre os procedimentos propostos respectivamente pelo verificacionismo e o falsificacionismo, só nos restaria fazer a opção por um dos dois aparatos lógicos de avaliação de teorias (científicas). O dilema epistemológico se reduziria basicamente a recolher ou bem evidência favorável ou bem desfavorável a nossas construções teóricas. Nada mais poderia ser sugerido como contribuição à problemática da estrita avaliação lógico-empírica de nossos sistemas interpretativos. Kuhn rejeita esse dilema tradicional quando declara que: "Ele (Popper) e seus seguidores compartem, com os mais tradicionais filósofos da ciência, da suposições de que se pode equacionar o problema da escolha de teorias através do uso de técnicas semanticamente neutrais" (Kuhn, 1976b:234). 
que é submetido o neófito - como condição de possibilidade para que venha a integrar uma comunidade científica - a grande responsável por sua adesão a certos procedimentos de justificação que a tradição tende a conceber como portadores de uma cogência puramente imanente? É claro que, se Kuhn não faz mais epistemologia pura, isso se deve ao fato de que, à diferença da tradição, deixou de acreditar que os dispositivos de justificação possam se legitimar apenas por sua eficácia lógica, atentando-se apenas para sua força intrínseca de avaliação das teorias substantivas. Quando se pergunta pela especificidade da "racionalidade científica", Kuhn não encaminha sua resposta na direção da estipulação de um critério. Lança questões que envolvem, também, nítida preocupação com aspectos psicossociais.

Pode-se dizer que o interesse maior da reflexão kuhniana é explicar as grandes transformações por que tem passado o conhecimento científico. Mas como são esporádicas as revoluções, Kuhn se dá conta de que precisa também elucidar o que ocorre nos períodos em que não despontam grandes invenções e descobertas. Seu empenho é no sentido de prover explicações para o rotineiro e o extraordinário em ciência. Trata-se de saber como a pesquisa convergente ou consensual pode desembocar, em última análise, em grandes reviravoltas nos modelos de explicação da realidade - em revoluções. Com base em que "critérios" - fatores (externos) e razões (internas) - técnicas de investigação e teorias substantivas são abandonadas e substituídas por outras? O projeto metacientífico kuhniano é uma tentativa de mostrar, misturando elucidações epistemológicas e análise de fatores psicossociais, que o cientista bem sucedido deve simultaneamente ostentar as características do tradicionalista e do iconoclasta: (Kuhn, 1977b:227, 236-7).

\section{(...) como uma firme orientação em direção a uma tradição aparentemente única pode ser compatível com a prática de disciplinas que se destacam justamente pela produção per- sistente de novas idéias e técnicas (Kuhn, 1977b:232).}

Sua teoria da ciência marca nítido afastamento tanto da tradição observacionalista/indutivista quanto da revisão crítica do ideal empirista da ciência levada a cabo por Popper (1968). Nega-se a escolher entre o modo verificacionista e o falsificacionista de conceber a cientificidade não por detectar deficiências na lógica da avaliação de teorias que propõem. Seu rechaço às concepções empirista lógica e racionalista crítica é antes conseqüência de sua convicção de que representam formas idealizadas de reconstrução da racionalidade científica incapazes de apreenderem como a física, a química etc. têm, de fato, evoluído. Por defender uma compreensão da racionalidade científica não confinada a aspectos estritamente lógico-empíricos de avalia- 
ção de teorias, Kuhn vê no verificacionismo e no falsificacionismo uma espécie de supressão dos aspectos dinâmicos do processo de produção de conhecimento, como se representassem propostas idealizadas de procedimentos a operacionalizar nos contextos específicos de pesquisa:

A competição entre segmentos da comunidade científica é o único processo histórico que realmente desemboca na rejeição de uma teoria antes aceita ou na adoção de outra (Kuhn, 1970:70).

Seu empenho é no sentido de mostrar que fatores, normalmente encarados como extrínsecos à "razão científica", são decisivos à compreensão de como e por que as comunidades científicas impõem (estatuindo normas de endosso e rechaço) certos modelos de produção intelectual a seus membros. Desse modo, ao assumir esse tipo de postura, Kuhn não tem como vincular sua obra à tradição do discurso epistemológico clássico, que só via relevância no estudo das razões lógico-empíricas por encará-las como as únicas capazes de determinarem a aceitação ou rejeição de nossos esquemas explicativos.

Tendo em vista a novidade contida no enfoque kuhniano, caberia questionar se representa a instauração de um novo (e híbrido) paradigma epistemológico ou se configura uma reflexão que, por misturar causas e razões, não tem como ser reconhecida como enquadrável na história dos problemas que a epistemologia reconhece como (os seus) legítimos. Este trabalho, apesar de sua finalidade didático-expositiva, almeja mostrar como Kuhn se aparta da tradição epistemológica e como tenta fundamentar o que há de novo em sua abordagem.

Por defender a tese ousada de que a racionalidade científica não tem como ser reduzida à utilização de critérios lógico-empíricos de avaliação de teorias, Kuhn lança mão de termos e expressões que não fazem parte do jargão epistemológico tradicional. É comum fazer alusão à habilidade, à conversão, à expectativa profissional, ao fracasso pessoal, ao consenso etc. como forma de tentar esclarecer como se constituem e reproduzem processos históricos de elaboração de conhecimento científico. Essas categorias não ocorrem de forma episódica e circunstancial em suas argumentações; cumprem função decisiva na medida em que Kuhn estabeleceu que "não há critério que se coloque acima do assentimento da comunidade relevante" (Kuhn, 1970:156).

A epistemologia anterior à "Nova Filosofia da Ciência" sempre deu proeminência à questáo de como podemos ordenar logicamente nossas teorias de modo a, cotejando-as com a realidade, por meio de testes, podermos caracterizá-las como verificadas, confirmadas (em um certo grau), falsificadas etc. Kuhn se propõe a empreender uma via metacientífica supostamente mais abrangente: 
Para descobrirmos como as revoluções científicas ocorrem, teremos, portanto, de examinar não apenas o impacto da natureza e da lógica, mas também as técnicas de argumentação persuasiva que se revelam eficazes no interior dos grupos muito especiais que constituem a comunidade dos cientistas (Kuhn, 1970:156).

De um ponto de vista semiótico, fica claro que Kuhn se recusa a circunscrever o discurso metacientífico a consideraçōes sintáticas (atinentes a requisitos de consistência) e semânticas (referentes aos níveis de correspondência entre teoria e "realidade"), uma vez que reputa fundamental, na caracterização da cientificidade, o recurso à pragmática (aos fatores bióticos da comunicação) sob a qual caem categorias como a de persuasão. Fazendo uma analogia com o pensamento de Platão, seria adequado dizer que a ciência, em Kuhn, não pode ser entendida como pura 'episteme', já que constitui uma atividade também envolvida com a 'erística', isto é, com o desenvolvimento de técnicas de convencimento em situações de controvérsia. Apesar de sua recusa em endossar a rígida separação entre contexto da descoberta e contexto da justificação, conforme proposta por Reichenbach, Hempel, Popper e outros, Kuhn não está interessado em promover a total dissolução da problemática tradicional de como podem ser adequadamente avaliadas nossas alegações de conhecimento. Só que não acredita que análises estritamente lógico-empíricas - sintático-semânticas - sejam capazes de esclarecer plenamente como as teorizações são aceitas ou rejeitadas no âmbito de uma comunidade especial, a científica ${ }^{3}$.

Será interessante averiguar se recorrer a categorias da pragmática como as de persuasão, conversão, consenso etc. equivale a tentar enxertar no discurso epistemológico elementos estranhos à sua singularidade explicativa ou se se trata de uma necessidade - brotada a partir da crise do modelo empirista clássico de ciência - de ampliar o raio elucidativo do discurso metacientífico de modo a vinculá-lo, interdisciplinarmente, a domínios como o da sociologia da ciência. Afinal, é a persuasão uma categoria capaz de integrar o rol dos procedimentos de justificação ou se reduz à mera adesão psicossocial que se acrescenta, de forma redundante, ao que lógica e empiricamente desponta como o que cabe ou não referendar?

3 É clara a proeminência conferida por Kuhn à categoria de comunidade (ausente dos textos tradicionais de epistemologia), quando afirma : "Um paradigma rege, antes de mais nada, não um objeto de estudo, mas um grupo de praticantes. Qualquer estudo sobre a pesquisa dirigida por paradigma ou destronadora de paradigma deve começar localizando o grupo ou grupos responsáveis" (Kuhn, 1970: 242 ). 
A "Nova Filosofia da Ciência", da qual Kuhn é um dos mais importantes representantes, pode ser vista como uma espécie de radicalização da crítica candente iniciada por Popper (1986) ao ideal empirista (lógico) de ciência. Parece óbvio que Kuhn tome como ponto de partida o ataque desferido por Popper (1989) contra o observacionalismo ${ }^{4}$. Com o racionalismo crítico, ficara evidenciado que: 1 . as teorias científicas não têm uma inevitável gênese observacional, que podem-se originar de intuições nascidas do ventre da metafísica, do mito etc.; 2 . obsenvações só podem ser feitas à luz de teorias; que o que tencionamos registrar, em um campo obsenvacional delimitado, é função de nossas expectativas, de nosso conhecimento anterior etc. Com Popper, deixara de fazer sentido atribuir a superioridade explicativa da ciência frente à metafísica e às pseudociências - ao fato de se dedicar a rigorosas e meticulosas observações por oposição ao vazio especulativismo. Abandonado o observacionalismo, o motor de desenvolvimento da ciência passa a ser visto como a delimitação de contextos problemáticos acompanhada das tentativas engenhosas de gerar soluções. Em clara sintonia com Popper, Kuhn ressaltará que, na constituição de um campo científico, o fundamental é definir o que em seu interior será considerado um autêntico problema ou uma adequada solução. Mas, apesar de, junto com Popper, destacar a formação de contextos problemáticos, dele diverge por não concordar que a ciência seja praticada em consonância com o esquema $\mathrm{P} 1 \rightarrow \mathrm{TT} \rightarrow \mathrm{EE} \rightarrow \mathrm{P} 2$..., segundo o qual os problemas são formulados, teorias tentativas são propostas, a eliminação de erros ocorre e novos problemas despontam.

No entanto, essa concordância quanto à profunda imbricação existente entre teoria e observação se faz acompanhar de divergências quanto à força do papel cumprido pela observação no processo de testagem das teorias ${ }^{5}$. Como é sabido, para Popper, um saber só é ciência quando submete suas laborações interpretativas a autênticos testes, que são sempre tentativas de refutação. Entrar em conflito com observações é, em um bom número de casos, o bastante para falsificar uma teoria e justificar seu abandono. Para Kuhn, testes decisivos com pretensões de falsificar uma teoria não são a mola propulsora de desenvolvimento da ciência; mesmo porque só são feitos esporadicamente em ciência e sua força não é absoluta, na medida em que fica a depender do impacto de outros

4 O observacionalismo também sofreu ataques, neste século, desferidos por insignes cientistas. Confirase a respeito Einstein \& Infeld (1966:31).

5 Eis, em linhas gerais, alguns dos principais pontos de concordância entre Kuhn e Popper : "Mas nem eu nem Sir Karl somos indutivistas. Não acreditamos que existam regras capazes de nos levarem a induzir teorias a partir de fatos, nem que teorias, corretas ou incorretas, sejam induzidas. Ao invés disso, nós as encaramos como postulações imaginativas, inventadas de uma só vez para serem aplicadas à natureza" (Kuhn, 1976a:12). E ainda : "Ambos enfatizamos, por exemplo, a íntima e inevitável imbricação entre observação e teoria científica; somos, por isso, céticos quanto à possibilidade de produzirse uma linguagem observacional neutra." (Kuhn, 1976a:2). 
fatores que extrapolam a preocupação obcecada em constatar que determinada teoria está em manifesta "dissonância cognitiva" com os fatos observados pertinentes. Na maior parte do tempo, o cientista mantém um envolvimento tão profundo com a teoria com a qual trabalha que não tem como testar crucialmente sua proficuidade explicativa.

Todas essas considerações deixam claro que Kuhn não tem como ser apresentado como um epistemólogo "ortodoxo" filiado a uma tradição que via na formulação de critérios de avaliação de teorias o alfa e o ômega de toda investigação metacientífica. Por essa razão, procuraremos, agora, identificar a forma pela qual Kuhn se posiciona frente ao problema central da epistemologia e da cientificidade.

\title{
2. CIÊNCIA: A PESQUISA SOB A BATUTA DE UM PARADIGMA
}

$\grave{A}$ diferença do que ambicionavam o verificacionismo e o falsificacionismo, não há em Kuhn a intenção de estatuir um critério capaz de distinguir, com alguma nitidez, o que é ciência e o que é pseudociência ou metafísica. Em momento algum, Kuhn estipula a forma a ser ostentada pelas teorias e os modos pelos quais se deve buscar evidência favorável ou contrária às suas pretensões de verdade para que possam ser consideradas científicas. Sua análise se limita a mostrar como tem sido historicamente construída a cientificidade, e não que requisitos lógico-empíricos precisam ser satisfeitos para que uma disciplina se converta em ciência.

\begin{abstract}
Concluo, em suma, que protociências, como as artes e a filosofia, carecem de algum elemento que, nas ciências maduras, enseja as formas mais óbvias de progresso. Esse comportamento não é, contudo, algo proporcionável por uma prescrição metodológica. Diferentemente de meus críticos atuais, e nesse caso particular incluo Lakatos, não reivindico terapêutica alguma capaz de auxiliar na transformação de uma protociência numa ciência. Tampouco suponho que se possa obter alguma coisa nessa direção. (Kuhn, 1976b:244-5)
\end{abstract}

Apesar de não se apresentar como proponente de um critério de cientificidade, a teoria da ciência kuhniana acaba por arrolar os traços distintivos exibidos por disciplinas que granjearam, de forma inconteste, o estatuto de ciência. Sem se confinar ao campo da estrita lógica de justificação de teorias, Kuhn sublinha que uma disciplina se torna ciência não porque se dedica a procedimentos de verificação ou falsificação (tentada) de suas teorizações, e sim porque funcio- 
nalmente ingressou em uma fase na qual os problemas são consensual e unificadamente enfrentados com base em padrões estandardizados de abordagem. $\mathrm{O}$ funcionalismo kuhniano almeja caracterizar as atividades típicas da investigação científica em suas fases e funções e não como produtos avaliáveis à luz de tal ou qual critério (universal).

Uma disciplina, para ingressar na etapa científica, precisa superar - na ótica de Kuhn - a guerra intestina em que diferentes escolas se digladiam em seu interior, com vistas a se tornarem a única via (reconhecida) para o genuíno conhecimento. E que, vencida a fase da guerra de todos contra todos, típica da pré-ciência, nasce a ciência propriamente dita, cuja "evolução" tenderá a obedecer ao seguinte esquema de tipo funcionalista:

$$
\begin{aligned}
& \text { Ciência normal } \Rightarrow \text { Crise } \Rightarrow \text { Pesquisa extraordinária } \Rightarrow \\
& \Rightarrow \text { Revolução } \Rightarrow \text { Nova ciência normal } \Rightarrow \text { Nova crise } \ldots
\end{aligned}
$$

Durante o período pré-paradigmático, é comum brotarem tantas teorias quantos pesquisadores há na área, porque prevalece um total desacordo e um diuturno debate sobre o básico, tanto no nível metodológico quanto no substantivo. Cada teórico vê-se como que obrigado a partir do zero, como se a começar tudo de novo, de modo a poder justificar o tipo de enfoque que adota. Há, nesse caso, uma manifesta dispersão dos esforços interpretativos a impedir que a pesquisa exiba avanços cumulativos. Os teóricos rivais no período da pré-ciência dissentem não só sobre o que se deve caracterizar como suposição teórica fundamental, como também o que deve ser visto como o tipo de fenômeno observacional relevante para a constituição de seus enredos hipotéticos:
Nenhum período entre a Antigüidade remota e o fim do sé- culo dezessete exibiu uma única concepção amplamente aceita sobre a natureza da luz. Havia, ao invés disso, um bom número de escolas e subescolas em competição (...) Cada uma dessas escolas derivava parte de sua força da re- lação que mantinha com alguma metafísica particular e cada uma enfatizava, como observações paradigmáticas, o conjunto específico de fenômenos óticos que sua teoria po- deria melhor explicar. (Kuhn, 1970:74-5)

Contrapondo-se aos que defendem a tese de que a atividade científica deve sempre procurar desenvolver o maior número possivel de teorias, Kuhn salienta que a proliferação de enfoques só ocorre nos períodos pré-paradigmáticos da pré-ciência ou durante as crises nas quais mergulham as teorias que, por algum tempo, dominaram a cena de alguma ciência, estipulando a metodologia a 
ser seguida e os problemas a serem atacados como legítimos. Ora, se a pré-ciência é concebida como a etapa em que se multiplicam improficuamente as teorizações sobre um campo, então a inauguração da ciência há de ser vista como a conquista do consenso, como a redução da multiplicidade interpretativa à unidade dos "modos de problematização e solucionamento" impostos pelo paradigma. Nesse sentido, a transição da pré-ciência para a chamada ciência (normal) se consuma quando a atividade de pesquisa desorganizada e dispersiva que antecede a formação de uma campo unitário de investigação passa a ser desenvolvida sob a égide de um paradigma endossado por toda a comunidade científica. A cientificidade pode, então, ser vista como um tipo de atividade explicativa que desenvolve pesquisas submetidas a princípios e pressupostos organizadores de uma paradigma.

Mas como se deve entender a noção de paradigma, vital à caracterização da cientificidade? Em The Structure of Scientific Revolutions, Kuhn não se empenha em veicular uma definição unívoca. Foi desorientadoramente prolífico em suas qualificações (Cf. Masterman, 1976:59-89; Shapere, 1964:384-5). Uma das veiculações mais elucidativas é a que sustenta que:

Paradigmas são realizações científicas universalmente reconhecidas que, durante algum tempo, fornecem problemas e soluções modelares para uma comunidade de praticantes. (Kuhn, 1970:58)

A partir do momento em que uma tradição de investigação tem força suficiente para definir que problemas são legítimos e que soluções são adequadas, cria uma territorialidade interpretativa para além de cujas fronteiras não se vai, como se nada além existisse. Ao pôr fim à contínua e improfícua competição entre diversas concepções sobre um "objeto" - por exemplo, sobre a luz, a eletricidade etc. -, o paradigma dá início à fase da pesquisa convergente e unificada, cuja eficácia residiria em seu poder de enfrentar as seguintes questões:

1. Quais as entidades fundamentais de que se compõe o universo? A resposta delimitará o campo ontológico pertinente:

(...) os que se dedicam a uma especialidade científica madura aderem profundamente a uma maneira de considerar e investigar a natureza, que se baseia num paradigma. $O$ paradigma thes diz que tipo de entidades povoa o universo e os modos pelos quais se comportam os membros dessa população (Kuhn, 1980:91). 
2. Que interrogações hipotéticas podem ser legitimamente formuladas a respeito de tais entidades?

3. Que técnicas podem ser empregadas na busca de soluções para o tipo de problema isolado como legítimo? A resposta especificará o método adequado para lidar com o que desponta como merecedor de explicação.

Com isso, fica claro que o método é função dos problemas acolhidos por cada ciência, que não há um método universal - como o de conjecturas e refutações proposto por Popper - a ser empregado na escolha e equacionamento dos contextos problemáticos. Não é o método, pela força de seus procedimentos de avaliação, que cria o paradigma; o paradigma é que especifica as técnicas de investigação a serem empregadas:

Homens cuja pesquisa se baseia em paradigmas compartiIhados estão comprometidos com as mesmas regras e padrões para a prática científica (Kuhn, 1970:73).

Como não é o método que diz ao paradigma que problemas escolher, e sim o contrário, os contextos problemáticos forjados pelos paradigmas são os únicos suscetíveis de ter sua legitimidade reconhecida durante sua vigência:

Outros problemas, inclusive muitos dos que eram antes vistos como estandardizados, são rejeitados como metafísicos, como de interesse de outra disciplina ou como demasiado problemáticos para merecerem dispêndio de tempo (Kuhn, 1970:99).

Se cabe ao paradigma definir, no âmbito de determinada disciplina, o que deve ser considerado autêntico problema, então não há um critério de cientificidade a regê-lo. O paradigma é a própria cientificidade: inaugura uma tradição consensualmente empreendida, determina que problemas reputar legítimos, que fatos devem se tornar objeto de reconstrução interpretativa, que outros suprimir etc. Aliás, sem paradigma, não temos como justificar a maior ou menor relevância que atribuímos a este ou aquele fato, uma vez que cada uma das múltiplas teorizações tenderá a destacar apenas o "conteúdo empírico" compatível com seus pressupostos explicativos: 
$\mathrm{Na}$ ausência de um paradigma, ou de um candidato a paradigma, todos os fatos que possivelmente poderiam se mostrar pertinentes ao desenvolvimento de determinada ciência têm probabilidade de parecer igualmente relevantes (Kuhn, 1970:77).

É interessante notar que o paradigma é, simultaneamente, uma teoria substantiva (ou de primeira ordem, isto é, sobre determinados "fatos") e uma teoria de segunda ordem, relativa a critérios estipuladores de quais (e como) fatos devem ser especificados para efeito de reconstrução explicativa. Daí Kuhn afirmar que

Ao aprender um paradigma o cientista adquire teoria, métodos e padrões conjuntamente, formando uma mistura inextricável (Kuhn, 1970:171).

Se o paradigma tem o poder de estipular o que deve ser considerado problema e soluções modelares, o que cabe observar e o que deve merecer destaque, então é claro que fornece a moldura e a tela na qual são pintados os conteúdos da pesquisa científica. Mas, além de prover as teorias de primeira e de segunda ordens, o paradigma cria em torno de si um consenso especial capaz de levar todos que a ele aderem a ver o mundo de maneira convergente. $\mathrm{O}$ paradigma equivale a instaurar uma mundividência ou Weltanschauung (Cf. Suppe 1977:135-50), a partir da qual os fenômenos ganham significatividade interpretativa relacional, tornando-se membros de um corpus teórico concebido como totalidade integrada. Mas, como as diferentes escolas ${ }^{6}$ que se antagonizam na fase pré-paradigmática da pré-ciência também veiculam visões de mundo, essa não pode ser a diferença específica da pesquisa feita sob a batuta de um paradigma. A visão de mundo contida em um paradigma tem a peculiaridade de ser compartilhada consensualmente como se fosse inevitável:

\section{(...) a história fortemente sugere que, embora se possa praticar ciência - como se faz filosofia, arte ou ciência política - sem um firme consenso, essa prática mais flexível não produzirá o padrão de rápido avanço científico encadeado a que os sécu- los recentes nos acostumaram. Com base nesse padrăo, o de- senvolvimento ocorre de um consenso para outro, e enfoques}

6 Kuhn faz a seguinte avaliação crítica de suas posições anteriores: "Seja lá o que for o paradigma, é possuído por qualquer comunidade científica, inclusive pelas escolas do assim chamado "período préparadigmático". Minha incapacidade de ver esse aspecto contribuiu claramente para tornar um paradigma uma entidade ou propriedade quase mística que, à semelhança do carisma, transforma os que são por ela contagiados. Há uma transformação, mas não é induzida pela aquisição de paradigma" (Kuhn, 1977a:460). 
alternativos não estão normalmente em competição. Exceto sob condiçōes bastante especiais, o praticante de uma ciência não pára para examinar modos divergentes de explicação ou experimentação (Kuhn, 1977b:232).

Se houvesse uma metodologia prévia e universalmente aceita pelos que aspiram a fazer ciência, ficaria claro que o consenso resultou da adesão a um conjunto geral de princípios e pressupostos definidores da cientificidade. Mas se o consenso é interior ao paradigma - e não anterior a ele -, então envolve teorias substantivas, teorias do método etc., que se impõem não apenas por seu valor intrínseco, mas por constituírem úma visão de mundo geradora de modos compartilhados de ver a natureza alcançados, também, pelo emprego de técnicas de argumentação persuasiva. Tanto o paradigma não é uma unidade puramente lógico-empírica, que Kuhn chega a enfatizar que não há argumentos de consistência (lógicos) ou de correspondência (empíricos) capazes de demonstrarem a superioridade de um paradigma sobre outro. A seu juízo, há uma variedade de fatores envolvidos no julgamento que um cientista faz dos méritos de uma teoria científica: há desde aspectos institucionais de uso da linguagem científica até uma análise da proficuidade explicativa. Como se pode constatar, o paradigma desponta como uma espécie de noção absoluta, uma vez que tem o poder de gerar, a partir de si mesmo, as teorias de primeira ordem (sobre "fatos"), as de segunda ordem (sobre critérios epistêmicos) e o consenso em torno de seus princípios e pressupostos:

O período pré-paradigmático é, em particular, regularmente marcado por debates freqüentes e profundos em torno de métodos, problemas e padrões de solução legítimos debates que servem mais para definir Escolas do que para produzir acordo (Kuhn, 1970:109-110).

Desse modo, o paradigma é a imposição de um framework, dentre muitos possíveis, com a conseqüente eliminação do confronto de óticas e da atitude crítica permanente que constituiriam as principais caraterísticas da pré-ciência. Nesse sentido, a criticabilidade, que Popper erigira em traço distintivo da cientificidade, desapareceria justamente no momento em que uma disciplina ingressasse na sua fase científica.

O paradigma não é síntese das diferenças entre as escolas. A desaparição das divergências é normalmente causada pelo triunfo de uma das escolas da fase pré-paradigmática. A vencedora, "em razão mesmo de suas crenças e preconcepções características, enfatizava apenas alguma parte especial do conjunto demasiado amplo e incoativo de informações" (Kuhn, 1970:79). O 
paradigma se impõe às escolas da fase pré-paradigmática, não tanto por sua abrangência, e sim por sua mundividência ter despontado a partir de determinado momento, como o modo adequado de ver e problematizar um campo fenomênico. Como estar uma disciplina submetida à Weltanschauung (organizadora) do paradigma é o que a torna científica, e isso significa rígido consenso supressor da crítica, estamos condenados a só propor interpretativamente o que é compatível com a fase em que se encontra uma disciplina. Isto quer dizer que, se desenvolvemos pesquisas em uma disciplina que se encontra sob irrestrito e incondicional domínio da perspectiva paradigmática, só podemos nos dedicar a atividades rotineiras de tentar resolver acriticamente os problemas propostos pelo paradigma.

Por a teoria do paradigma não equivaler à proposição de um critério por intermédio do qual são definidas as condições gerais necessárias, ainda que não suficientes, a serem satisfeitas por uma disciplina para poder ser ciência, Kuhn intenta fazer um inventário histórico reconstrutivo de como os saberes têm-se convertido em ciência. Uma outra diferença capital tem a ver com o fato de que, por não propor um critério, Kuhn está menos interessado em definir quando uma teoria pode aspirar à condição de científica e mais em assinalar quando uma disciplina ingressou na fase paradigmática (científica), por terem diferentes escolas "se unificado" sob a batuta de uma ótica que daí em diante regerá esse campo de investigação.

Tudo isso deixa claro que, quando fala em pré-ciência, Kuhn não tem em mente a pseudociência como ilusão cognitiva gerada por insuperável falta de conteúdo empírico ou por eventuais confusões lógico-lingüísticas de expressão (à la empirismo lógico); tampouco pensa em modalidades de saber que desenvolvem sistemas interpretativos irrefutáveis, isto é, incapazes de entrar em conflito com a experiência (à la Popper). Como pré-ciência, Kuhn caracteriza a fase das pesquisas em que falta unidade de propósitos investigativos por ainda não se terem imposto certos tipos de problema e certos modelos de solução. Essa fragmentação da pesquisa em direções divergentes faz com que inexista progresso ${ }^{7}$. Daí afirmar que, durante o período pré-paradigmático, quando temos uma mul-

7 Para Kuhn, o progresso seria consequência do consenso propiciador de formas convergentes de pesquisar, de problematizar um domínio específico de investigação, e não da aplicação de uma metodologia meliorista que nos ensinaria a construir teorias cada vez melhores (mais verossimilhantes) através da permanente e implacável eliminação de erros: "Se duvidamos, como fazem muitos, que áreas não científicas realizem progresso, isso se deve não ao fato de que escolas individuais não progridem. Deve-se, isto sim, à existência de escolas em competição, cada uma delas questionando os fundamentos das outras. Quem argumenta que a filosofia, por exemplo, não progrediu consegue com isso apenas enfatizar que ainda existem aristotélicos e não que o aristotelismo não tenha conseguido progredir" (Kuhn, 1970:224-5). 
tiplicidade de escolas em competição, torna-se muito difícil encontrar provas de progresso. Se há progresso, é relativo ao território demarcado por cada escola. Como a cientificidade resulta da emergência de um paradigma, não faz sentido discutir in abstracto que método especial e que tipo de depuração ideológica fariam com que a sociologia progredisse como a física. Para Kuhn, o que assegura o progresso não é o acordo sobre definições, sobre técnicas de investigação a empregar, e sim o consenso em torno de como deve ser conduzida a prática de pesquisa. Não se trata de concordância em torno de uma teoria da ciência, estipuladora dos cânones de investigação, mas em torno de como deve ser praticada uma disciplina que entra na fase paradigmática.

\section{CIÊNCIA NORMAL: A REPRODUÇÃO DO CONSENSO}

A existência de um paradigma, que dá origem à tradição de investigação conhecida como ciência normal, é que representa a inauguração de um tipo de pesquisa capaz de distinguir ciência de não-ciência. A questão é que ingressar na fase da ciência normal ${ }^{8}$ não é algo que se consegue assumindose a postura de só construir teorias suscetíveis à verificação, confirmação ou falsificação. O paradigma não corresponde a um mero conjunto de requisitos lógico-empíricos tendentes a tornar possível fazer ciência e justificá-la. Pela ampla gama de componentes que envolve, o paradigma que rege uma pesquisa impõe práticas de observação e teorização constituídora de uma tácita visão de mundo. Nesse sentido, prescrições do tipo "envide todos os esforços no sentido de falsificar suas teorias" soariam inócuas por ser, consoante a perspectiva kuhniana, praticamente impossível alguém ver simultaneamente à luz do paradigma e livre de seus óculos enquadradores.

Criticar as teorizações em torno das quais criou-se o consenso implicaria como que desmontar um modo de fazer ciência que penosamente se consolidou. Desse modo, a prescrição falsificacionista equivaleria, em última análise, a uma proposta de diuturno ataque ao consenso que seria, no ver de Kuhn, a condição de possibilidade do tipo de pesquisa que se faz numa disciplina que in-

8 Toulmin (1972:100) faz descrição altamente elucidativa da fase batizada por Kuhn de ciência normal: "Durante os longos períodos de ciência "normal", as idéias correntes em (digamos) física são dominadas e moldadas por uma teoria-mestra geral ou "paradigma". Ao aceitarem um paradigma, os cientistas estabelecem, durante algum tempo, as preocupações intelectuais e os padrões racionais a vigorarem em seu campo específico de investigação: que questões formular, que formas de explicação reputar aceitáveis, que interpretaçōes reconhecer como legítimas. Nesse aspecto, um paradigma tem a mesma função lógica de uma constelação de pressuposições absolutas. Os cientistas que trabalham sob a autoridade de um paradigma formam uma escola, praticamente do mesmo tipo que uma escola de artistas". 
gressa em sua fase científica. Uma vez alcançado o consenso, só razões imperiosas (não confináveis à realização de testes cruciais) levam os pesquisadores a questionar as bases sobre as quais apóiam seu trabalho. Mas se a pesquisa submetida a um paradigma não se caracteriza apenas por sua maneira peculiar de lidar com a empeiria, o que a torna singular? Para Kuhn, estar uma disciplina sob a égide de um paradigma significa que seus pesquisadores praticam o que chama de ciência normal. A famosa imagem de Newton, retomada por B. Russel, segundo a qual os cientistas de hoje precisam, para que seu trabalho se torne possivel, subir nos ombros de seus predecessores, guarda muita semelhança com a ciência normal kuhniana. Esse avançar linear e cumulativo seria a marca registrada de uma forma de saber em que todos dirigem seus esforços para o aprimoramento dos as'pectos funcionais (seus modos de solucionar problemas) das explicações providas pelo modelo adotado por uma tradição, que se cristalizou em uma disciplina como única aparentemente possível.

Em Second Thoughts on Paradigms (1977a), Kuhn reconhece que seu antigo uso do termo paradigma confunde duas noções bastante distintas: exemplares, que são tipologias de solução de problemas concretos aceitas pela comunidade científica, e matrizes disciplinares, que são os elementos compartilhados que explicam o caráter relativamente não-problemático da comunicação profissional e a relativa unanimidade de julgamento profissional subsistente em uma comunidade científica:

Um sentido de paradigma é global, abrangendo todos os compromissos compartilhados por um grupo científico; o outro isola um tipo particularmente importante de compromisso e é, portanto, um subconjunto do primeiro"..."No livro (The Structure), o termo paradigma tem praticamente o mesmo significado da expressão "comunidade científica". Um paradigma é o que os membros de uma comunidade científica, e apenas eles, partilham (Kuhn, 1977a:460).

À semelhança do que defendera em The Structure, Kuhn não vê as matrizes disciplinares como aprendidas por um receituário metodológico, e sim como processo educacional por meio do qual alguém é guindado à posição de praticante de uma especialidade científica. Diferentemente do que ocorre em outras áreas, na iniciação científica, os manuais ${ }^{9}$ desempenham um papel globalmente plasmador, vinculando o neófito a uma espé-

9 Kuhn (1977b:228) assinala que: "A característica singular mais marcante dessa educação (nas ciências naturais) tem que ver com o fato de que é, numa extensão totalmente desconhecida em outros campos, conduzida inteiramente através de manuais." 
cie de Great Chain unitária. Não por acaso, os manuais científicos, elementares ou avançados, dão demasiada ênfase à dependência que a pesquisa atual tem da passada. É claro que, de um ponto de vista histórico, as realizações científicas proporcionam modelos, centrados em determinados princípios e pressupostos, orientadores da prática posterior. A crença nesse "fio condutor" serve para dar unidade, no tempo, ao que vem sendo desenvolvido ao longo das diversas etapas evolutivas e para propiciar a busca de identidades:

\begin{abstract}
A Física de Aristóteles, o Almagesto de Ptolomeu, Os Princípios e a Ótica de Newton, a Eletricidade de Franklin, a Química de Lavoisier e a Geologia de Lyell - esses e muitos outros trabalhos serviram por algum tempo para definir implicitamente os problemas e métodos legítimos de um campo de pesquisa para as gerações posteriores de praticantes da ciência (Kuhn, 1970:72).
\end{abstract}

Ao invés de tentar localizar as características básicas (preferencialmente lógico-empíricas) que diferentes sistemas interpretativos exibem para se credenciar a ser ciência, Kuhn cita-os como campos fundadores de uma modalidade de pesquisa submetida a requisitos geradores de uma tradição cumulativa de obtenção de resultados. Como cada ciência se desenvolve em uma mesma direção, salvo quando ocorrem descontinuidades revolucionárias, seus praticantes podem se dedicar à constante lapidação de soluções para problemas consensualmente acatados como os que de fato são relevantes:

A pesquisa normal, mesmo seus melhores produtos, é uma atividade altamente convergente baseada firmemente num consenso alcançado através de educação científica e reforçado pela posterior vida profissional (Kuhn, 1977b:227).

A ciência normal é praticada por uma comunidade científica que compartilha uma matriz disciplinar baseada em um estoque partilhado de exemplares. A ciência normal constitui uma tentativa de subsumir uma classe cada vez maior de fenômenos sob a visão de mundo básica provida pela matriz disciplinar em evolução. Essa unanimidade, esse acordo profundo, característica da pesquisa normal não deve ser vista como fruto de coações externas. Resulta dos processos de iniciação especiais que precedem a entrada de alguém para a comunidade científica. É a educação científica que a torna possível. Os manuais redigidos para estudantes por membros "experientes" da comunidade científica constituem meios pedagógicos propiciadores da unanimidade. Mas a convergência existente na 
ciência normal não significa um genérico acordo do tipo "todos pensam a mesma coisa", e sim o que dá ensejo ao que Kuhn denomina de modalidade esotérica de pesquisa. E é exatamente isso que constitui sinal de maturidade de uma ciência. Mas é claro que a pesquisa esotérica seria impossivel se não existisse uma longa e penosa arte de iniciação através da qual um aspirante, sob a supenvisão de um cientista, se familiariza com os métodos, as técnicas e os padrões do paradigma. Nesse sentido, realizar experimentos estandardizados e se dedicar a solver problemas padronizados não é submeter-se a prescrições metodológicas, e sim inserir-se em um sistema de educação profissional muito complexo e disciplinador, como é o caso do científico.

Nos antípodas do que sustenta Popper, para Kuhn a rotina do trabalho científico não se caracteriza pela busca de novidades capazes de, pela derrubada das interpretações aceitas, levarem à ampliação de horizontes e à conquista de melhores teorias:

Não está entre os objetivos da ciência normal trazer à baila novas espécies de fenômeno; na verdade, os que não se ajustam à moldura freqüentemente nem são vistos (Kuhn, 1970:86).

A confiança no paradigma é tanta que as anomalias não são vistas como casos refutadores da teoria, mas como quebra-cabeças a serem resolvidos por nossa imaginatividade heurística. Isto mostra que, quando fazemos pesquisa sob um paradigma não temos "liberdade" para testá-lo, da forma crucial apregoada pela tradição epistemológica, em razão de nossa submissão aos seus padrões ser responsável pela identificação dos problemas que devem ser considerados dignos de equacionamento. É claro que, vivendo em um paradigma, o cientista pouco se empenha para inventar novas teorias ou descobrir novos fatos, chegando até a mostrar-se intolerante para com eventuais propostas alternativas ao seu framework.

Por ser setorial e esotérica, a pesquisa normal equivale a uma espécie de mergulho em uma "pequena realidade", impedindo praticamente que outros domínios de objetos sejam tematizados. A assunção consensual de determinados compromissos ontológicos (o que há a investigar é isto e não aquilo) e o endosso tácito a determinados princípios metodológicos (especificadores dos problemas legítimos e das soluções modelares) diminuem drasticamente a importância da atitude crítica entronizada por Popper em valor epistêmico supremo:

\footnotetext{
(...) é exatamente o abandono do discurso crítico que marca a transição para uma ciência. Quando um campo passa por tal transição, o discurso crítico só reaparece nos momentos de crise quando as bases do campo estão novamente em risco (Kuhn, 1976a:6-7).
} 
É exatamente a falta de discordância sobre aspectos fundamentais que distingue, para Kuhn, a ciência normal madura da atividade desorganizada da pré-ciência. $\mathrm{O}$ império da crítica só se mostraria funcionalmente necessário em uma fase em que diversos caminhos interpretativos fossem propostos sem que ainda se tivesse chegado a um consenso em torno do que e como investigar. Nesse sentido, a crítica só é decisiva quando uma disciplina se encontra na etapa pré-paradigmática ou quando um paradigma longamente aceito entrou de fato em crise. Se ver/estudar a realidade a partir de um paradigma é se deixar conduzir pelas veredas interpretativas que abre, então nossa força de crítica contra o que dispõe implica em pelo menos começar a deixar de ver a "realidade" através de suas janelas interpretativas.

Mas, ao mesmo tempo que representa uma drástica redução do que potencialmente pode ser visto, o paradigma também enseja que se estudem segmentos da realidade com um grau de profundidade e detalhamento inatingiveis se não nos levasse a ciência normal a concentrar a atenção em um conjunto de problemas esotéricos. Ademais, o tipo esotérico de trabalho, desenvolvido pela pesquisa normal, só é possivel porque os cientistas, quando trabalham sob a batuta de um paradigma, não têm necessidade de dedicar boa parte de seus esforços à atividade "filosófica" preocupada com a fundamentação das posições assumidas. A ausência de escolas competidoras, que questionam mutuamente seus objetivos e critérios, torna viável a pesquisa esotérica e palpável a sensação de progresso. Durante os períodos em que predomina a ciência normal, os pesquisadores têm a convicção de que suas investigações progridem - lidam com problemas do mesmo tipo cada vez mais complexos e sofisticam gradativamente seu arsenal de soluções.

A crítica experiencial, intensamente enfatizada por Popper, deixa de ser decisiva, no esquema de Kuhn, na medida em que não há "fatos em si", sob forma de contra-exemplos, mas só "fatos" do (e para o) paradigma. Submeter nossas teorizações à experimenta crucis só começa a se tornar possível a partir do momento em que o paradigma deixa, por variadas razões, de se mostrar intocável. Um paradigma não pode, portanto, ser visto como uma teoria suscetível de ser abandonada se, por exemplo, conflita com observações. Como é o paradigma que define e operacionaliza o modo de fazer ciência, só pode ser atacado se entrou em crise e principalmente se começa a emergir um outro em condições de substituí-lo com vantagens. $E$ isto se mostra claro quando se tem presente que a atividade conspícua do paradigma é a pesquisa normal com sua reconhecida aversão a novidades. Afinal, só a curiosidade em perscrutar "novos fatos", em abrir novos horizontes interpretativos etc. poderia dar plausibilidade prática à atitude epistemológica que defende, à maneira de Popper, o permanente e implacável teste de nossas teorias. Ao não se interessar por novidades, a ciência nor- 
mal apenas aprimora a capacidade explicativa que tem dos tipos de problema que classifica, com base em seus próprios pressupostos, como autênticos. Isto faz com que, quando as coisas não se passam do modo previsto pelo paradigma, se manifeste a tendência a considerar o fracasso em aproximar-se do resultado antecipado como um "fracasso pessoal do cientista" (Cf. Kuhn, 1970:97-8).

\begin{abstract}
(...) em última análise, é o cientista individual e não a teoria corrente que é testada. Uso o termo "quebra-cabeça" para enfatizar que as dificuldades com que normalmente se deparam até os melhores cientistas são, como os quebra-cabeças de palavras cruzadas ou de xadrez, apenas desafios à sua engenhosidade. Ele é que está em dificuldade, não a teoria corrente. Minha posição é quase a inversão da de Popper (Kuhn, 1976a:5).
\end{abstract}

Como se vê, antes de mais nada, se testa a capacidade solucionadora do indivíduo; um experimento só desponta como teste crucial de uma teoria sob circunstâncias bastante especiais. Mesmo porque, se a atividade de solucionar puzzles tivesse sempre êxito, o desenvolvimento da ciência não teria, como sublinha Kuhn, como conduzir a qualquer tipo de inovação fundamental (Cf. Kuhn, 1970: 73). Mas é preciso que a ciência ingresse na fase denominada por Kuhn pesquisa extraordinária, para que se torne possível realizar testes decisivos com nossas teorizações. Nesse sentido, o caráter do teste - crucial ou não - é função da fase em que se encontra a pesquisa em determinada ciência - normal ou extraordinária - e não da força da evidência que fala contra uma teoria. Só quando os membros da comunidade científica não têm mais como esquivar-se das anomalias que subvertem a tradição imperante da ciência normal acrítica é que têm início investigações extraordinárias no interior das quais o contra-exemplo é, de fato, algo que pode comprometer a teorização em questão.

É comum a ciência normal, no movimento de expansão linear de seu escopo explicativo, esbarrar em fenômenos anômalos que não se coadunam com o esperado. Quando tais anomalias são identificadas, tem início um trabalho por meio do qual se faz uma exploração mais ou menos ampla da área da anomalia, com o intuito de enquadrá-la na moldura suprida pela visão de mundo da matriz disciplinar. Se esse empreendimento acomodador falha, se a anomalia continua a resistir aos ataques que intentam neutralizá-la, emerge uma crise, que cria as condiçóes básicas para o advento de uma revolução. A novidade que precipita a crise só desponta para aquele que, conhecendo com precisão o que deveria esperar, é capaz de reconhecer que algo correu mal. Há, ainda, a acrescentar que, em inúmeras circunstâncias, simples anomalias só se transformam em fonte de crise a partir da influência de fatores extrínsecos ao desenvolvimento interno da ciência. 
Mas se assim é, como e quando o resultado negativo de um teste pode ser considerado não um fracasso pessoal do experimentador e sim como a derrocada explicativa da teoria? Não há, para Kuhn, uma resposta possível baseada na estrita função desempenhada pelos requisitos lógico-empíricos. Tudo depende da fase em que se encontra o paradigma sob o qual fazemos nossos exercícios interpretativos: se for a da pesquisa normal, nenhuma chance há de despontar como falsificação o que aparece como evidência desfavorável, ao passo que, se está no bojo de uma crise, pode o contra-exemplo aparecer com o poder que the atribui Popper - o de falsificação da teoria ${ }^{10}$.

Em função de o paradigma não representar a instauração de um campo de investigação a partir da especificação apriorista de um conjunto de prescrições metodológicas ${ }^{11}$, Kuhn dá bastante destaque ao processo pedagógico, através do qual alguém se habilita a se tornar praticante de uma ciência. A educação (científica), que na epistemologia tradicional é vista como decorrência do método abraçado, em Kuhn (1970:108) desponta como modeladora dos sistemas de representação da realidade.

A atitude científica é inculcada ao longo do processo de aprendizagem do próprio paradigma; não é a vontade obsessiva de verificar ou falsificar teorias que vai tornar paradigmática uma investigação. Trabalhar sob um paradigma já é submeterse a suas delimitações substantivas, e seus rituais epistêmicos independem de o cientista querer ou não imprimir esta ou aquela direção ao curso de pesquisa que empreende. $O$ pesquisador não cataloga os problemas em legítimos e inautênticos em função de poder ter para uns soluções teóricas verificáveis (à la empirismo lógico) ou falsificáveis (à la Popper) e para outros só poder oferecer especulação metafísica. A autenticidade epistêmica é paradigm-bound no sentido de que depende do que no interior do paradigma emerge como genuíno puzzle passível de ser adequadamente enfrentado nos limites de seu domínio interpretativo. Para Kuhn, o próprio fato de os cientistas não se perguntarem pelo que torna legítimo um problema ou uma solução específica seria evidência de que não dispõem de um critério geral de distin-

10 A tradição epistemológica sempre se reportou à necessidade de a teoria estar em correspondência com a realidade. Kuhn sugere a inversão de direção quando afirma que a ciência normal:"...parece uma tentativa de forçar a natureza a encaixar-se na moldura pré-formada e relativamente inflexível fornecida pelo paradigma" (Kuhn, 1970:86).

11 A posição de Kuhn frente às regulamentaçōes metodológicas fica clara quando proclama: "Não há um conjunto de regras de escolha adequada que se possa impor como comportamento individual desejado nos casos concretos com os quais se defrontarão os cientistas ao longo de suas carreiras. Seja o que for o processo científico, temos de explicá-lo examinando a natureza do grupo científico, descobrindo suas valorações, o que tolera, o que desdenha".(...) "Esta posição é intrinsecamente sociológica e, como tal, configura um importante afastamento dos cânones de explicação apregoados pelas tradições que Lakatos rotula de justificacionismo e falsificacionismo (em sua versão dogmática e ingênua)" (Kuhn, 1976b:238). 
ção, capaz de definir autenticidade epistemológica, e sim de um conhecimento tático dos possíveis modos de problematização aceitáveis no âmbito do paradigma (Cf. Kuhn, 1970:106, 110-111).

A ciência normal congrega, sobretudo, atividades de resolução de quebra-cabeças, lapidação de resultados, aprimoramento de técnicas de acomodação de dificuldades etc. A ciência madura, a que desenvolve a pesquisa normal, é obviamente regida por um paradigma que prevê os padrões de investigação para o trabalho reputado legítimo e que coordena os modos de tentarmos equacionar os puzzles teóricos e experimentais. Sendo assim, a ciência normal constitui um tipo de empreendimento de pesquisa altamente cumulativo voltado para o aprofundamento e detaIhamento do que estipula o paradigma como seu itinerário de investigação: "A ciência normal não almeja descobrir novidades do tipo fatual ou teórico; quando bem sucedida simplesmente não as encontra" (Kuhn, 1970:114).

Isto quer dizer que, se o paradigma impõe efetivamente "seus modos de ver as coisas", pouca chance há de detectarmos novidades ou de lhes creditarmos maior importância. Destarte, a força de um paradigma reside em não nos deixar identificar "fatos" discrepantes com seu arcabouço empírico e em não nos levar a pensar em teorias dissonantes, isto é, inconciliáveis com seu escopo explicativo.

O revolucionarismo meliorista de Popper (o desenvolvimento da ciência não se dá por acumulação de resultados, e sim pelo permanente empenho revolucionário de derrubar uma teoria aceita para pôr em seu lugar outra melhor) só seria, no entender de Kuhn, aplicável aos raros momentos em que a pesquisa normal é abandonada para dar lugar à emergência da crise seguida pela pesquisa extraordinária, que normalmente deságua em revolução. Mas como, para Kuhn, o que distingue ciência de não-ciência é a pesquisa normal, disso se segue que o critério de demarcação popperiano deixaria de fora justamente o traço distintivo da cientificidade: o "consenvadorismo" do acúmulo de resultados respaldadores de determinada tradição de pesquisa historicamente ensinada como um paradigma:

\section{(...) é a ciência normal, onde não existe o tipo de testagem defendido por Popper, e não a ciência extraordinária, que quase sempre distingue ciência de outros empreendimen- tos. A existir um critério de demarcação (...) só pode-se vin- cular justamente à parte da ciência que Popper ignora (Kuhn, 1976a:6).}

Tentando mostrar a improficuidade do criticismo popperiano, Kuhn sublinha que os profissionais são treinados para a prática da ciência normal, e não para a extraordinária, como se a sugerir que os cientistas não têm como livrar-se da camisa de força pedagógica no interior da qual se desenrolou sua formação de pesquisadores. É claro que se o paradigma não fosse, em condições normais, 
o único território interpretativo por onde pode transitar o cientista, não faria qualquer sentido proclamar que o cientista não pode ser crítico porque não foi preparado para ter impostação crítica. Mesmo porque poderia tê-la independentemente de ter recebido uma educação que o doutrinou para ser "obediente" ao estatuído pelo paradigma. Mas, como o paradigma não tem como ser explicativamente manipulado como bem apraz ao cientista, então estar sob seu domínio significa ver com seus óculos, não fazendo sentido criticar as lentes que são - bem ou mal - o que possibilita algum tipo de ver.

Por supor que os compromissos básicos são efetivamente postos à prova na fase da ciência extraordinária, Kuhn é levado a declarar que a educação científica treina seus profissionais justamente para a reprodução acrítica da matriz disciplinar. Por estipular que pontos devem ser testados e como a ciência normal não abre espaço para que o pesquisador possa se debruçar sobre seus pressupostos e fundamentos. A ser procedente esse arrazoado, a autêntica testagem só pode ter início quando se começa a deixar de ver tudo com os óculos do paradigma. E quando isso ocorre, vive-se a fase da transição em que se começa a abandonar um paradigma por já se vislumbrar a virtual emergência de um outro.

Opondo-se ao ponto de vista de que testes decisivos podem a todo instante ser realizados, (Kuhn 1976a:5) salienta que episódios revolucionários são muito raros no desenvolvimento de uma ciência. Popper teria, na visão de Kuhn, caracterizado toda a atividade científica através de categorias epistemológicas que se aplicam, na melhor das hipóteses, a seus esporádicos períodos revolucionários. O que Kuhn chama de pesquisa extraordinária é o que mais se aproximaria da proposta popperiana que defende a realização de diuturnas e implacáveis tentativas de derrubada revolucionária da teoria aceita para que seja substituída por outra melhor:

Somente quando precisam escolher entre teorias rivais, os cientistas se comportam como filósofos. A meu ver, esse é o motivo pelo qual a brilhante descrição popperiana das razões para a escolha entre sistemas metafísicos se parece tanto com minha descrição das razões que determinam a escolha entre teorias científicas. Em nenhuma das escolhas (...) a testagem desempenha papel decisivo (Kuhn, 1976a:7).

O papel que Popper atribui ao contra-exemplo parece assemelhar-se ao que Kuhn chama de experiências anômalas. No entanto, uma análise mais acurada mostrará que são semelhantes apenas na aparência: Kuhn não acredita que existam as tão propaladas experiências de falsificação. Justifica sua descrença afirmando que: 1 . Nenhuma teoria resolve todos os quebra-cabeças 
com os quais se defronta em dado momento. 2. Se todo e qualquer fracasso na tentativa de ajustar teoria e dados fosse motivo suficiente para a rejeição dos sistemas interpretativos, todas as teorias seriam sempre e prematuramente rejeitadas (Kuhn, 1976a:208) ${ }^{12}$. Ademais, é a inexistência de total acordo entre teorias e dados que suscita muitos dos quebra-cabeças aos quais a ciência normal dedica suas mais engenhosas tentativas de solução.

\section{A ROTA PARA A CRISE}

A ser válido o descritivismo kuhniano, a ciência se formaria e se consolidaria fazendo exatamente o contrário do que Popper apregoa ter valor epistêmico universal: abandonando a atitude crítica. Afinal, a transição da préciência para a ciência representaria o fim dos debates entre escolas rumo à "unificação" das diferenças sob a batuta de um paradigma propiciador da pesquisa normal, cuja principal característica é a de mostrar-se pouco sensível às novidades e de só testar o que é instanciável no horizonte teórico-fatual demarcado por seus pressupostos.

Chegar à fase paradigmática corresponde à desaparição da impostação crítica que só voltará à cena quando eclodir uma crise. Mesmo porque, não ter paradigma algum, ou ter muitos paradigmas e começar a fracassar o paradigma que se tem, são situações bastante semelhantes no sentido de que, em todos esses casos, não se impõe um modo unitário de "nos fazer ver as coisas". E quando muitas são as vias interpretativas possíveis, somos levados a enfrentar a espinhosa questão dos fundamentos do enfoque que desenvolvemos para o que isolamos como os principais "fatos" e problemas de nosso campo de investigação.

A relativização da força dos experimentos, associada à maçante rotina da pesquisa normal, torna a ciência impermeável à crítica que, na opinião de Popper, seria o principal meio de nos desvencilharmos dos erros e produzirmos teorias melhores. Mas, por mais que a pesquisa normal seja a prática comum e rotineira da ciência, não é eterna sua vigência. Mudanças, mais cedo ou mais tarde, acabam ocorrendo. Descobertas (novidades relativas a fatos) e invenções (novidades

12 As críticas ao empirismo crítico popperiano ficam ainda mais claras quando Kuhn relativiza o impacto da experiência sobre nossas construções teóricas: "A observação e a experiência podem e devem restringir drasticamente o escopo das crenças científicas admissíveis, pois do contrário não haveria ciência. Mas não podem, por si só, determinar um corpo específico de semelhantes crenças" (Kuhn, 1970:66). 
referentes à teoria) acabam sendo feitas ${ }^{13}$. A metaciência kuhniana, apesar de toda ênfase que faz recair sobre a pesquisa normal, é uma reflexão que caracteriza a atividade científica como oscilando entre a rotina repetitiva do trabalho aprimorador do que se sabe (em maior ou menor grau) e as dramáticas invenções/descobertas que desembocam nas revoluções. Nesse sentido, a explicação que Kuhn dá sobre a racionalidade científica se estriba na distinção fundamental entre ciência normal e revolução científica. Sua alegação de que, na maior parte do tempo, a ciência se dedica à pesquisa normal, levada a cabo pelos membros das comunidades científicas que se integram através da posse comum de uma matriz disciplinar, em nada diminui a importância dos raros episódios revolucionários. A ciência normal cumpre a decisiva função "sincrônica" responsável pelos longos períodos de pesquisa convergente, ao passo que as revoluções configuram o desenvolvimento do conhecimento no eixo diacrônico das grandes transformações dissonantes com tudo que até então vinha sendo feito. Mas, se a ciência deve ser entendida como se produzindo entre a pachorrenta reprodução do normal (simples atividade de resolução de puzzles) e a introdução revolucionária de novos modos de ver a "realidade" (de problematizá-la), então cabe identificar o que determina a subversão de uma longa tradição de investigação, isto é, o que determina a falência explicativa do time-honoured paradigma.

Para Kuhn, a descoberta começa a ser feita quando se passa a ter consciência de uma anomalia, isto é, quando se reconhece que a natureza, de alguma maneira, deixou de se enquadrar no campo interpretativo delimitado pelo paradigma que rege a ciência normal. Contudo, as primeiras identificações de anomalias costumam ser tentativas de acomodá-las ao framework do paradigma.

As anomalias, fenômeno(s) para o(s) qual(is) o paradigma não preparou o pesquisador, são, em princípio, desconsideradas em seu importe teórico-fatual e creditadas a falhas dos cientistas individuais. Quebra-cabeças que resistem à solução são vistos como anomalias mais do que como taxativas falsificações, mais como um fracasso do cientista individual do que como uma inadequação do paradigma. Até porque, todos os paradigmas contêm anomalias que, como se pode retrospectivamente constatar, se faziam desde o início presentes. Exemplos disso são a teoria copernicana e o tamanho aparente de Vênus, a física newtoniana e a órbita de Mercúrio. Mas como o cientista mostra-se totalmente acrítico com relação ao paradigma no interior do qual trabalha, há uma tendência a subestimar a

13 Acompanhemos como Kuhn pensa a relação entre anomalia e inovação através da seguinte passagem: "Qualquer que seja o grau de genialidade empregada para observá-las, a verdade é que as anomalias só emergem do curso normal da atividade científica quando instrumentos e conceitos se desenvolveram o bastante para tornar provável sua emergência e para tornar a anomalia resultante reconhecível como uma violação de expectativas. Dizer que uma descoberta inesperada só começa quando algo dá errado é dizer que só começa quando os cientistas sabem bem como seus instrumentos e a natureza deveriam se comportar" (Kuhn, 1977b:173-4). 
importância das anomalias. Ausente a impostação crítica na ciência normal, o pesquisador pode-se dedicar à articulação funcional e detalhada das peças do paradigma através do trabalho esotérico.

A mera existência de puzzles não-solucionados no interior de um paradigma não é suficiente para desencadear uma crise de confiança no paradigma. Mesmo porque, todo e qualquer sistema explicativo já nasce com maiores ou menores conflitos efetivos com a experiência. Para Kuhn, aderir ao postulado popperiano - segundo o qual devemos abrir mão de teorias que se deparam com evidência negativa - seria inviabilizar a atividade científica, uma vez que equivaleria a não ficar com teoria alguma o tempo todo.

Só em determinadas situações as anomalias podem assumir uma importância capaz de abalar a confiança depositada num paradigma. Só quando atinge a estrutura básica do paradigma e resiste às mais engenhosas tentativas de removê-las - feitas pelos mais insignes membros da comunidade científica - é que sua existência passa a ameaçar a tradição da ciência normal. A identificação de uma anomalia pode marcar apenas o começo de uma descoberta. O que necessariamente se segue, se é que algo acaba descoberto, é um período mais ou menos longo durante o qual o indivíduo, e freqüentemente muitos membros de seu grupo, luta por enquadrar a anomalia numa lei.

Se fica constatado que a anomalia coloca a integridade explicativa do paradigma em sérias dificuldades, é comum ter início um período de "revisionismo intelectual" e de grande insegurança profissional decorrentes do sentimento de que se está diante do início do processo de derrocada do paradigma e de grandes alterações nos tipos de problemas e técnicas de resolução impostos pela ciência normal. Mas, para Kuhn, não é a economia interna da ciência a única responsável por não vermos uma anomalia como uma ocorrência questionadora do valor explicativo do paradigma. A anomalia é vista como séria sobretudo se relacionada a alguma necessidade premente do contexto social (Cf. Kuhn, 1970:131).

Uma nova teoria não surge porque a que existia entrou em conflito com a experiência, e, sim, porque se configurou um fracasso, não mais do cientista, mas da atividade normal de resolução de problemas. Metodologicamente falando, só a constatação do fracasso das regras vinculadas ao paradigma desencadeia a busca de novos caminhos epistemológicos. A prolífica atividade de invenção de diferentes teorias só é abraçada como necessária na fase pré-paradigmática (ou multiparadigmática) da pré-ciência e pode também ser desenvolvida quando se está nos primeiros estágios da confecção de um novo paradigma.

Se a anomalia continua resistindo à análise (o que geralmente não acontece), muitos cientistas podem passar a considerar sua resolução como o objeto de estudo específico de sua disciplina. Os primeiros ataques desferidos contra o problema não resolvido seguem bem de perto as regras estatuídas pelo paradigma. Mas se ainda 
assim continua a haver resistência, podem-se, então, buscar vias cada vez menos "ortodoxas" de lidar com a dificuldade, chegando-se ao ponto de, apesar de existir um paradigma, não haver acordo entre os cientistas em torno de sua natureza $\mathrm{e}$ identidade. Quando se chega a essa situação, mesmo os antes intocáveis padrões de solução de problema passam a ser questionados.

Como as crises representam o relaxamento da rígida instauração interpretativa promovida pelo paradigma, com o conseqüente afrouxamento das regras que regem a ciência normal, tem origem um período similar à fase pré-paradigmática com a diferença de que, nas crises, o campo de divergência é menor e menos claramente definido. Segundo Kuhn, há três desfechos possíveis para a crise: 1. a ciência normal acaba se revelando capaz de lidar com o problema que gerou a crise; 2 . o problema resiste até mesmo a novas abordagens. Tal constatação pode levar a duas conclusões. Os cientistas supõem que nenhuma solução será encontrada no estado atual da área de estudo. Os cientistas propõem que seja colocado de lado e legado a gerações futuras que talvez venham a contar com instrumentos mais acurados; 3 . fim da crise com o advento de um novo candidato a paradigma e subseqüente batalha por sua aceitação.

\section{A NATUREZA DA REVOLUÇÃO CIENTÍFICA: A IRRUPÇÃO DO DISSENSO}

Só quando o paradigma está enfraquecido a ponto de seus velhos defensores perderem a confiança irrestrita que antes depositavam nele é que amadurecem as condições para a revolução (científica). Durante o período em que se dá a transição de um paradigma em crise para um novo, a partir do qual pode emergir uma nova tradição de ciência normal, cessa o modo cumulativo de produção de conhecimento. Opera-se, nessa fase, a reconstrução da área de estudos a partir da adoção de novos princípios epistemológicos e da assunção de outros compromissos antológicos, de tal modo que, terminada a transição, os cientistas terão modificado amplamente a concepção que tinham de sua disciplina porque terão alterada radicalmente sua visão da natureza, sua mundividência:

Em dissonância com a ótica dominante, a maioria das novas descobertas e teorias nas ciências não são meras adiçóes ao estoque de conhecimento científico existente. Para assimilálas, o cientista deve normalmente rearrumar o equipamento intelectual e manipulativo no qual anteriormente confiou, descartando alguns elementos de sua crença e prática anteriores, descobrindo novos significados e novas relações entre muitos 
outros. Em razão de o velho dever ser reavaliado e reordenado quando se dá a assimilação do novo, descoberta e invenção nas ciências são quase sempre intrinsecamente revolucionárias (Kuhn, 1977b:226).

$\mathrm{Na}$ ótica de Kuhn, as grandes transformações em ciência configuram a manipulação basicamente do mesmo conjunto de dados antes considerado, só que estabelecendo entre eles um novo sistema de relações interpretativas organizado a partir de um framework diferente. Essas reviravoltas de perspectiva se assemelham, ao ver de Kuhn, a uma reversão gestáltica exemplificável pelo caso famoso em que um desenho é visto ora como coelho, ora como pato. Mas, à diferença do sujeito da gestalt, o cientista não passa constantemente de uma maneira de ver para outra. Por longos períodos só vê, só pode ver, pato. É necessário que reavalie seus princípios e pressupostos para se habilitar a ver coelho.

Fica claro, com base no funcionalismo kuhniano, que o normal da ciência só pode ser assim caracterizado por oposição a um momento revolucionário esporádico, e vice-versa. A racionalidade da descontinuidade é, antes de mais nada, conseqüência da falência da continuidade, já que Kuhn não prevê a possibilidade de se propor uma nova teoria (um novo paradigma) sem que a já aceita tenha mergulhado em crise profunda capaz de minar suas principais bases de sustentação. A crise é prelúdio da emergência de nova teoria que rompe com uma tradição de prática científica para introduzir uma nova dirigida por regras diferentes. Esse bouleversement só ocorre quando se percebe que a tradição anterior estava bastante equivocada. Ora, como as crises (e a ameaça de teorias rivais à aceita) precipitam não só a mudança de paradigma como também uma ampla redefinição de critérios epistêmicos, de compromissos ontológicos etc., o cientista mostra tendência a desenvolver, durante o período da pesquisa extraordinária, um tipo de reflexão bastante parecido com a filosófica, exibindo inclusive preocupação em lidar com a problemática dos pressupostos e fundamentos, ausente do seu horizonte de interesses enquanto fazia ciência normal:

Na medida em que o trabalho de pesquisa normal pode ser conduzido valendo-se do paradigma como modelo, as regras e pressupostos não precisam ser explicitados (...). Não é por acaso que a emergência da física newtoniana no século dezessete e da relatividade e da mecânica quântica no século vinte foram precedidas e acompanhadas por análises filosóficas fundamentais da tradição de pesquisa contemporânea (Kuhn, 1970:150).

O recurso à filosofia, ao arsenal de questões de segunda ordem que formula, é prova cabal de que o monolitismo da ciência normal se esboroou; o início de uma discussão sobre regras, pressupostos e fundamentos é sintoma claro de que se con- 
sumou a transição da ciência normal para a extraordinária. A pesquisa extraordinária atinge seu ápice quando enseja a transição para um novo paradigma, quando promove uma descontinuidade de grandes proporções - uma revolução. Kuhn denomina revoluções científicas aos episódios de desenvolvimento não-cumulativo nos quais um paradigma time-honoured é total ou parcialmente substituído por um novo, incompatível com o anterior (Cf. Kuhn, 1970:154).

Para explicar a natureza das revoluções científicas, Kuhn lança mão de analogias com as revoluções políticas. As revoluções políticas teriam início, para Kuhn, com o sentimento (inicialmente restrito a um grupo) de que as instituições existentes deixaram de se mostrar capazes de fazer frente às dificuldades e aos desafios decorrentes das exigências de funcionalidade equilibrada entre os diversos setores e segmentos formuladores de uma ordem social. Já a revolução científica eclode quando o paradigma deixa de funcionar adequadamente na exploração explicativa de algum aspecto da natureza anteriormente identificado pelo próprio paradigma: "Tanto no desenvolvimento político quanto no científico, o sentimento de funcionamento defeituoso que pode levar à crise é pré-requisito para a revolução" (Kuhn, 1970:154).

Continuando o paralelo, Kuhn afirma que as revoluções políticas almejam mudar as instituições de uma forma proibida por sua atual funcionalidade. Em razão de as facções em luta dissentirem quanto à matriz institucional que deve ser usada para viabilizar e avaliar a mudança política, porque não reconhecem a existência de um framework supra-institucional capaz de julgar suas diferenças revolucionárias, as partes envolvidas num conflito revolucionário devem, em última análise, recorrer a técnicas de persuasão de massa e até à força (Kuhn, 1970:155). No caso da revolução científica, deixa de existir a matriz disciplinar, base e fundamento da pesquisa convergente normal, e as diferenças interpretativas não têm como ser arbitradas com base em estritas razões ou justificativas. Trata-se de uma luta cujo desfecho determinará o modo de ver - a visão de mundo - vencedor. E como um modo de ver se vincula a um modo de viver, a mudança de paradigma equivale praticamente a abraçar uma nova forma de vida: ${ }^{14}$

Tal como a escolha entre instituições políticas competidoras, a que se dá entre paradigmas rivais se apresenta como uma escolha entre modos incompatíveis de vida comunitária (Kuhn, 1970:156).

14 Como é sabido, o Wittgenstein II, das Philosophische Untersuchungen ( $\$ 202$ e $\$ 241$ ), deu grande destaque à noção de forma de vida. Kuhn, mesmo não fazendo uso explícito de tal noção, a pressupõe: "A visão kuhniana de ciência é descritiva. Seu conceito central, paradigma, tem muitos significados, mas certamente o significado correspondente ao conceito wittgensteiniano de jogo de linguagem como forma de vida é central. O conceito complementar à ciência normal, o conceito de revolução científica, corresponde ao do uso wittgensteiniano de reversão gestáltica" (Radnitzky, 1979:109). 
É interessante, a esta altura da exposição, sublinhar que, ao passo que a tradição epistemológica se empenhava no sentido de mostrar que as ciências sociais só conquistariam sua cientificidade se imitassem o pretenso método utilizado pelas naturais, Kuhn se vale de inúmeras categorias das ciências sociais com vistas a tentar elucidar a racionalidade científica em geral. Fica-se, em certas circunstâncias, com a impressão de que procura corrigir as distorções do velho naturalismo/fisicalismo recaindo involuntariamente num sociologismo generalista tão ou mais problemático ${ }^{15}$. Afinal, qual o estatuto epistemológico da teoria política/sociológica através da qual pretende oferecer uma reconstrução da racionalidade das revoluçōes científicas? ${ }^{16}$ A tentativa de elucidar o que se passa numa ciência através de categorias pertencentes a uma outra é sempre bastante problemática. Mais ainda quando um domínio não tem sua cientificidade consensualmente estabelecida. Afinal, é incontroversamente científica a teoria das revoluções políticas a ponto de poder ser ampla e incondicionalmente empregada no esclarecimento do que se passa quando da mudança de paradigma?

15 As declarações dadas por Kuhn sobre as ciências sociais se chocam frontalmente com o amplo uso que faz de categorias pertencentes, ao menos por razões de jurisdição acadêmica, à sociologia, à política etc.: "Se ele (Popper) quer dizer que as generalizações que constituem as teorias aceitas em sociologia e psicologia (e em História?) são linhas muito fracas com as quais se possa tecer uma filosofia da ciência, eu não poderia deixar de estar em total acordo com ele. Tanto meu trabalho quanto o dele não se estribam nelas. Se, por outro lado, está pondo em dúvida a relevância que os tipos de observações coletadas por historiadores e sociólogos tem para a filosofia da ciência, aí já não sei como seu próprio trabalho poderá ser compreendido" (Kuhn, 1976a:235). Esta passagem encerra grande dose de ambigüidade. Tenciona, por um lado, se desvincular dos conceitos e generalizações tradicionais das ciências sociais e, por outro, defender genericamente o tipo de atividade interpretativa e sua importância para a filosofia da ciência, desenvolvida por sociólogos, historiadores etc. Ademais, Toulmin conseguiu mostrar como a teoria da revolução kuhniana se vincula a pressupostos que se revelaram controversos na teoria política no interior da qual tinham sido inicialmente endossados: "Inicialmente, os pensadores liberais democratas se viram tentados a tratar o termo (revolução) como algo mais. A seus olhos, a constante mudança constitucional representava uma continuidade política 'racionalmente inteligível'; por contraste, as revoluções políticas configuravam quebras da 'normalidade', que introduziam descontinuidades históricas insuscetíveis de análise em termos normais racionais. Atualmente, no entanto, os cientistas políticos tentam evitar o contraste exagerado entre "mudança normal" e "revolução". Mesmo a mudança mais inconstitucional não envolve rupturas absolutas e compreensivas da continuidade política. As mais dramáticas revoluçōes jamais levam a um absoluto rompimento com o passado. Continuidades jurídicas, administrativas e de costumes sempre sobrevivem..."(Toulmin, 1972:117).

16 Não podemos evitar este tipo de questão em virtude da ambivalência exibida por Kuhn em relação à natureza do conhecimento sociológico: categorias sociológicas precisam ser usadas para se entender a constituição e a reprodução da racionalidade científica, mas o que se tem feito em sociologia não é ciência. Não por acaso, Kuhn descarta certas tradições de pesquisa social sem, no entanto, definir por qual opta (ou por qual se deveria optar) no trabalho metacientífico reconstrutivo: "Examinando casos controversos como, por exemplo, a psicanálise e a historiografia marxista para as quais, conta-nos Popper, teria inicialmente forjado seu critério, concordo que não podem propriamente ser chamadas de ciência" (Kuhn, 1976a:7). 
Kuhn não só inverte o velho naturalismo como também colide frontalmente com a tradição epistemológica quando retira dos requisitos lógico-empíricos o papel determinante de avaliadores da veracidade das teorizações. O naturalismo e o "epistemologismo" são ambos atacados com as mesmas armas: o recurso a categorias político-sociológicas como meio de esclarecer a sincronia e a diacronia dos processos históricos de produção de conhecimento científico. A lógica cede muito de seu poder à erística, a força inapelável dos contra-exemplos é subordinada à argumentação persuasiva, a universalidade intersubjetiva torna-se caudatária dos modos funcionais de (re)produção de consenso nas comunidades científicas etc.:

$\mathrm{Na}$ escolha de um paradigma, tanto quanto nas revoluções políticas, não existe critério superior ao assentimento da comunidade relevante. Para descobrirmos como as revoluções científicas ocorrem teremos de examinar, portanto, não apenas o impacto da natureza e da lógica, mas também as técnicas de argumentação persuasiva, que se revelam eficazes no interior dos grupos muito especiais que constituem a comunidade dos cientistas (Kuhn, 1970:156).

Pouca serventia tem acrescentar técnicas de argumentação persuasiva aos requisitos lógicos de coerência e aos imperativos empíricos de correspondência, quando o fundamental é determinar se, e em que medida, convencer é uma categoria capaz de nos levar a pensar num modelo de racionalidade totalmente distinto daquele que se diz calcado apenas nas ações de demonstrar logicamente e comprovar empiricamente. Kuhn chega a afirmar que os argumentos não são individualmente decisivos, que não há argumentos puramente lógicos nem evidência empírica inconcussa capazes de determinar a superioridade de um paradigma sobre outro:

Não podemos recorrer a noções como as de "verdade" ou "validade" dos paradigmas se tencionamos compreender a eficácia especial da investigação que sua aceitação permite fazer (Kuhn, 1980:90).

Formulações desse tipo têm sido tachadas pelos críticos de Kuhn de irracionalistas - "a matter for mob psychology"17. Kuhn rechaça com veemência esse

17 Lakatos também faz a seguinte interessante comparação : "Para Popper, a mudança científica é racional ou pelo menos suscetível de reconstrução facional e cai no domínio da lógica da descoberta. Para Kuhn, a mudança científica - de um paradigma para outro - é uma conversão mística que não é e nem pode ser regida por regras da razão e que cai totalmente no domínio da psicologia (social) da descoberta. A mudança científica é uma espécie de mudança religiosa" (Lakatos, 1976:93). (...) "Mas o programa de pesquisa kuhniano contém um novo traço: temos de estudar não a mente do cientista individual, mas a mente da Comunidade Científica. A psicologia individual é assim substituída pela psicologia social; imitação dos grandes cientistas pela submissão à sabedoria coletiva da comunidade" (Lakatos, 1976:178-9) 
tipo de rotulação. No entanto, se a tradição epistemológica estiver certa não tanto pelas respostas que oferece, mas pela delimitação dos problemas que considera legítimos - a metaciência kuhniana despontará, na melhor das hipóteses, como fidedigna descrição da ciência até aqui produzida, mas não como reconstrução da racionalidade científica que culmina na enunciação de algum critério de decisão epistêmica.

Há claros indícios de que, para a metaciência pós-popperiana, um dos problemas centrais a equacionar é o relativo à natureza da mudança científica. Pretendendo-se respaldado pela história da ciência, Kuhn caracteriza a mudança científica como essencialmente revolucionária. Mas, à diferença da tradição epistemológica, não acredita na existência de um conjunto de princípios (lógico-empíricos) capaz de ensejar a comparação entre teorias rivais à luz de um background evidencial minimamente compartilhado. Nem o requisito lógico da consistência e nem o da fidedignidade empírica teriam força suficiente para demonstrar a superioridade de uma teoria sobre outra. Kuhn chega a sustentar que cada grupo utiliza seu próprio paradigma para argumentar a favor de sua legitimação. Se há essa circularidade, decorrente de inexistirem princípios de comparação aplicáveis a diferentes teorizações, é claro que vivemos na "prisão interpretativa" do paradigma. Por serem os critérios sempre paradigm-bound, isto é, por terem uma validade circunscrita ao domínio do paradigma ao qual se aplicam (e do qual retiram sua legitimidade) não há como utilizá-los na avaliação das escolhas feitas.

Mas se as regras lógicas e a "força da experiência" não conseguem elucidar a transição, como poderiam fazê-lo as técnicas de argumentação persuasiva? Afinal, com elas, ficaria quando muito demonstrado que ingressamos num outro paradigma, mas não por que razões. Se os requisitos sintáticos (de coerência) e semânticos (de correspondência) não conseguem explicar a transição, terão as categorias pragmáticas (por exemplo, a persuasão) poder para tanto? Não se pode esquecer que estas últimas pressupóem os dois outros: afinal, quem se persuade - sobretudo no campo da pesquisa empírica - se persuade de alguma coisa (relação entre o que se diz e o que é) veiculada através de certa roupagem argumentativa (a natureza das inferências feitas). Ao invés de apenas conferir proeminência à esfera pragmática - consenso, persuasão, conversão etc. -, Kuhn deveria tentar mostrar como se associa à sintaxe e à semântica nos processos históricos específicos de produção de conhecimento científico.

Kuhn recorre a importantes exemplos extraídos da psicologia da percepção, sobretudo gestaltista, em apoio à sua tese de que um cientista com um novo paradigma vê "as coisas" de maneira diferente da que via quando dissecava a natureza à luz de outra matriz disciplinar. Nesse sentido, a descontinuidade entre paradigmas se relaciona diretamente com uma gestalt 
switch (reversão gestáltica) através da qual se produz uma profunda alteração nos modos de percepção antes prevalecentes (Cf. Morick, 1980:17). Ver deixa de ser mero registro do que se passa à nossa volta para se transformar numa questão de visão de mundo. Não por acaso, Lavoisier viu oxigênio onde Friestley vira ar desflogistizado e outros nada viram...

Guiados por um novo paradigma, os cientistas adotam novos instrumentos e olham em novas direçōes (...) durante as revoluções os cientistas vêem coisas novas e diferentes quando, utilizando instrumentos familiares, dirigem seu olhar para lugares anteriormente por eles examinados. É como se a comunidade profissional tivesse sido subitamente levada para outro planeta onde objetos familiares são vistos sob uma luz diferente e a eles se juntam objetos diferentes (Kuhn, 1970:173).

Há nítidas implicações relativistas nesse ponto de vista de que podemos ver coisas diferentes quando olhamos para o mesmo tipo de objeto. ${ }^{18}$ Afinal, o que muda quando deixamos um paradigma para trabalharmos sob a égide de outro? É evidente que não se pode imaginar que o mundo qua tale mude, e sim que se alteram apenas as interpretações que os cientistas dão às observações. Ocorre, porém, que a reversão gestáltica é muito mais que mera reinterpretação dos mesmos dados. A tese da reinterpretação pressupõe que as observações são sempre idênticas a si mesmas, sendo as variações resultantes da imbricação com os quadros teóricos no interior dos quais são feitas. Nesse sentido, se pudéssemos fazer observações sem teoria poderíamos falar em ação puramente registradora. Quando Kuhn afirma que, embora o mundo não mude com a mudança de paradigma, mas que depois da mudança o cientista trabalha num mundo diferente, parece querer se limitar a reconhecer apenas a profunda interpenetração de teoria e observação que faz com que alterações nos quadros teóricos ocasionem outro mapeamento da realidade ${ }^{19}$. No entanto, sua teoria da percepção e

18 Toulmin afirma que o "endosso tácito a uma teoria idealista do conhecimento encoraja Kuhn a aceitar uma teoria idealista da percepção" (Toulmin, 1972:101).

19 Toulmin faz o seguinte comentário: "Que exemplos poderíamos invocar como possíveis ilustrações dessas totais mudanças na visão de mundo científica? Dois candidatos promissores são a reviravolta da astronomia pré-copernicana para a nova ciência de Galileu e Newton (...) e mais recente da física clássica de Newton e Maxwell para a física relativista de Einstein e a quântica de Heisenberg e seus sucessores (...). Em nenhum dos dois casos o esquema de completa revolução se ajusta aos fatos. Trata-se de uma caricatura descrever, por exemplo, a reviravolta da física newtoniana para a einsteiniana como uma completa descontinuidade racional... Numa ciência altamente organizada como a física, toda modificação proposta - por mais que ameace desencadear profundas mudanças na estrutura conceitual da área - é discutida através de argumentos e razões, criticada à exaustão antes de ser endossada e incorporada ao corpo estabelecido da disciplina. Na verdade, quanto mais radicais e abrangentes as mudanças teóricas propostas, mais elaborada e prolongada tenderá a ser a discussão" (Toulmin, 1972:103). 
da mudança conceitual colide frontalmente com o ponto de vista de que o novo paradigma introduz apenas uma simples reinterpretação dos mesmos dados:

O que acontece durante uma revolução científica não é totalmente redutível a uma reinterpretação dos dados individuais e estáveis. Em primeiro lugar, os dados não são inequivocamente estáveis (...) o cientista que abraça um novo paradigma é como o homem que usa lentes inversoras. Deparando-se com a mesma constelação de objetos que antes, e tendo conhecimento disso, ele os encontra, no entanto, totalmente transformados em muitos de seus detalhes (Kuhn, 1970:183-4).

Por caracterizar de forma nebulosa a natureza do processo de mudança científica, pode Kuhn recorrer, de forma justapositiva, a categorias da sintaxe, da semântica e da pragmática sem especificar o tipo de papel particular desempenhado por cada uma delas. Em razão de abraçar uma versão genérica da tese da subdeterminação da teoria pelos fatos, Kuhn se vê livre para caracterizar a identificação de anomalias e a emergência de revoluções como processos determinados tanto por razões (internas) ${ }^{20}$ quanto por causas (externas). Resolve-se, assim, a velha contraposição entre história interna e história externa da ciência identificando artificialmente razões e causas. Mas que outro caminho poderia ser trilhado pela metaciência que defende o ponto de vista segundo o qual: "a competição entre paradigmas não é o tipo de batalha que pode ser decidido por meio de provas" (Kuhn, 1970:210).

Daí Kuhn sustentar que a comunicação entre proponentes de diferentes teorias é inevitavelmente parcial ${ }^{21}$, que o que cada um considera fato depende em parte da teoria que adota e que a transferência de lealdade de uma teoria para outra "é melhor descrita como converso mais do que como escolha" (Kuhn,

20 Kuhn (1957, capítulos 5 e 6) caracteriza do seguinte modo a estrutura lógica de uma revolução científica: um esquema conceitual acaba por levar a resultados incompatíveis com a observação. Como se pode ver, nessa fase, anterior a The Structure, Kuhn está bem próximo da metaciência popperiana. Chega, inclusive, a afirmar que a incompatibilidade entre teoria e observação é a fonte última de qualquer revolução nas ciências. Já na fase de The Structure, Kuhn concebe o paradigma como estipulando os princípios inquestionados em torno dos quais se organizam os modos partilhados de uma comunidade realizar seu trabalho de pesquisa.

21 Kuhn declara que: "Proponentes de teorias diferentes são como falantes de diferentes línguas maternas. A comunicação entre elès se dá através de tradução, e isso gera todas as conhecidas dificuldades de tradução. A analogia é, naturalmente, incompleta, pois o vocabulário das duas teorias pode ser idêntico e a maioria das palavras funcionar da mesma maneira em ambas. Mas as mesmas palavras dos vocabulários básico e teórico das duas teorias - palavras como 'estrela' e 'planeta', 'mistura' e 'composto', ou 'força' e 'matéria' - funcionam de modo diferente" (Kuhn, 1977b:338). 
1977b:338). A relativização do valor das provas empíricas, das regras lógicas de inferência junto com a adoção de uma teoria idealista da percepção desembocam na controvertida tese da incomensurabilidade ${ }^{22}$ :

Por se tratar de uma transição entre incomensuráveis, a transição entre paradigmas em competição não pode ser feita de forma gradual, por imposição da lógica e da experiência neutra. Tal como a reversão gestáltica, a transição deve ocorrer de uma só vez (embora não necessariamente num instante) ou então simplesmente não ocorrer (Kuhn, 1970:212).

Para que não vejamos o enfoque kuhniano como psicologia ou sociologia da ciência mesclada à epistemologia ou como epistemologia em clave psicológica ou sociológica, terá a história de nos provar que os problemas epistemológicos nunca mais serão os mesmos depois de The Structure of Scientific Revolutions. Isto porque, por poder envolver uma autêntica revolução epistemológica, teremos de ser convertidos ao paradigma descontínuo que instaura. A valer a lógica que aplica ao envolver normal e revolucionário da ciência, não podemos aderir à novidade de seu arcabouço epistemológico sem passarmos por uma reversão gestáltica. Enquanto não usamos os óculos epistemológicos kuhnianos, temos de nos conformar em apenas marcar algumas diferenças com a tradição epistemológica. Quem sabe estaremos assim nos preparando para uma mudança all at once de perspectiva...

Não há, da parte de Kuhn, interesse de propor procedimentos de justificação; há sempre uma vaga alusão a fatores externos e os fatores funcionais (internos) não chegam a configurar em momento algum uma ars probandi. Não há dúvida de que a história da ciência está sendo o tempo todo reconstruída, na obra de Kuhn, a partir de um framework epistemológico tácito, ao mesmo tempo em que é apresentada como respaldando determinada visão sobre a ciência. Kuhn sabe que por mais que a evidência histórica referende uma imagem sobre a ciência, não pode ser usada como fundamento de cânones de investigação similares aos propostos pela tradição. Destarte, ou a epistemologia é análise reconstrutiva de determinado(s) estágio(s) de desenvolvimento de certas ciências ou é simples formulação de procedimentos a-históricos idealizados. Kuhn parte desse dilema e se inclina por inocular na epistemologia histórica o recheio psicossociológico:

22 Com relação às implicações subjetivistas/relativistas contidas no enfoque sociológico kuhniano que se insinua recentemente no discurso epistemológico, sugerimos a leitura das críticas feitas por Scheffler, 1967:64-89. 
Já devia ter ficado claro que a explicação, na fase final, precisa ser psicológica ou sociológica, isto é, precisa ser uma descrição de um sistema de valores, de uma ideologia, juntamente com uma análise das instituições através das quais o sistema é transmitido e inculcado (Kuhn, 1976a:21).

Náo se pode ser contra ou a favor a priori da mistura de categorias epistemológicas com outras psicológicas ou sociológicas. O que se deve sempre fazer é avaliar a proficuidade de tal enfoque no esclarecimento das peculiaridades da racionalidade científica. Se entendermos racionalidade científica em sentido lato, o enfoque kuhniano se mostrará extremamente fecundo; se a confinarmos ao valor puramente intrínseco das teorizaçōes pouco acrescentará, uma vez que não faz proposta inovadora alguma no que tange aos rituais de justificação dos sistemas explicativos.

Se aplicarmos ao próprio Kuhn as categorias através das quais lê alguns dos principais momentos da história da ciência, ficaremos com a convicção de que, com sua reflexão, a epistemologia começa a sair da fase normal, começa a reconhecer anomalias, pode estar a caminho de mergulhar numa crise e já pode até estar no limiar de uma revolução. Ou pode não ser nada disso... Se ficar constado que as fases kuhnianas de desenvolvimento das ciências maduras - pré-paradigmática, paradigmática e revolucionária - não são inexoráveis (ocorreram, ocorrem e ocorrerão sempre) na história da ciência, nem por isso perderão sua importância. São tipos-ideais construídos pela imaginação criadora que muito contribuíram para ajudar a esclarecer esse obscuro objeto da razão chamado ciência. 


\section{Feyerabend/Lakatos: \\ "adeus à razão" ou construção de uma nova racionalidade?}

Anna Carolina Krebs Pereira Regner

\section{INTRODUÇÃO}

\section{ALCANCE EPISTEMOLÓGICO DA HISTÓRIA DAS CIÊNCIAS: O QUESTIONAMENTO DA "RACIONALIDADE"}

U

$m$ traço distintivo de recentes análises do conhecimento científico - dentre as quais encontram-se as de Paul Feyerabend e Imre Lakatos - reside no papel substantivo atribuído à história das ciências para a compreensão da natureza e desenvolvimento deste conhecimento. A história das ciências deixa de ser um recurso meramente ilustrativo e passa a ter um sentido propriamente epistemológico. Não se trata, contudo, de uma busca ingênua do referencial histórico, que o supusesse erigido independentemente dos condicionantes impostos pela interrogação do epistemólogo. Trata-se de uma história que instrui em sendo instruída - seja na condição de uma "reconstrução racional", como o diz Lakatos (Lakatos, 1987a), seja na de uma "estória contada", como o contrapõe Feyerabend ${ }^{1}$. Em ambos os casos, vale a paráfrase de Kant ${ }^{2}$ feita por Lakatos: "A Filosofia da ciência sem a história da ciência é vazia; a História da ciência sem a filosofia da ciência é cega" (Lakatos, 1987a:11). Feyerabend refere-se a este mútuo remetimento da reflexão filosófica e do material histórico em termos da necessária combinação do argumento abstrato com o malho da história: "O argumento abs-

1 Referindo-se à transição da ciência aristotélica à ciência moderna, ocorrida nos séculos XV e XVI, Feyerabend diz que: "Meu propósito não é, entretanto, o de oferecer uma versão acadêmica e sim o de contar um conto de fadas, que talvez venha a se transformar, algum dia, em versão acadêmica e que se mostra mais realista e mais completa do que o conto de fadas insinuado por Lakatos e sua máfia" Feyerabend 1977:314-315).

2 "Pensamentos sem conteúdos são vazios, intuições sem conceitos são cegas" (Kant, 1974:57). 
trato é imprescindível porque imprime sentido à nossa reflexão. A história, entretanto, é também imprescindível, ao menos no atual estágio da filosofia, porque dá força a nossos argumentos". (Feyerabend, 1977:244)

O questionamento da "racionalidade" - condição para as demais indagações - a que somos levados pelas análises que buscam "um ponto de ataque no material histórico", a usar uma expressão de Feyerabend (1977:262), é testemunho da aguçada profundidade epistemológica de tais análises. A primeira constatação de fundo a ser feita é que remetem à discussão de uma racionalidade contextualizada - como faculdade e elementos ("razões") por esta produzidos ou arrolados, perfazendo a ratio ou o padrão de racionalidade da situação explicativa - ainda que os critérios para se entender esta contextualização nem sempre sejam os mesmos ${ }^{3}$. É sob o prisma de sua contribuição a esta discussão que serão a seguir examinadas as análises da ciência empreendidas por Paul Feyerabend e por Imre Lakatos. Suas posições conflitam? Aparentemente, sim. Enquanto Feyerabend explicitamente propõe-se a atacar uma posição racionalista (Feyerabend, 1977), Lakatos propõe-se a substituir a versão ingênua do racionalismo crítico popperiano por uma sofisticada (Lakatos, 1979) e, assim, coloca-se numa trilha racionalista, ainda que de "princípios de racionalidade radicalmente diferentes" (Lakatos, 1979:139). Contudo, um adentramento em suas posiçōes pode fazer-nos recuar de uma resposta tão simples e imediata e perguntar o que, afinal, está em jogo. É uma crítica ao proceder por "razóes" enquanto tal, ou à sua tradicional delimitação?

\section{A PROPOSTA "RACIONALISTA" DE LAKATOS}

Lakatos propõe a metodologia dos programas de pesquisa, demarcadora de sua visão do que seja ciência, como culminância de um processo de sucessivas teorias da racionalidade com seus modelos de conhecimento científico corporificados em quesitos metodológicos e encerrando códigos de honestidade científica (Lakatos, 1979) ${ }^{4}$. Contra o ideal "justificacionista" - intelectualista (a priorismo) e empirista (indutivismo) - da racionalidade clássica, com um modelo de conhecimento científico em termos de conhecimento "provado", permitindo a aceitação apenas daquelas proposições provadas ou inferidas (dedutiva/indutivamente) de proposições provadas, Lakatos assinala que valeu a crítica cética, com o

3 Exemplos para tais diferenciações ou, mesmo, divergências, encontram-se nas discussões acerca das diferentes ênfases e exclusões/inclusões a serem postas na história "interna" ou na "externa", na dimensão "objetiva" de "epistemologias" ou "racionalidades regionalizadas" e na função e caráter "subjetivo" ou "objetivo" dos valores das "comunidades" que produzem o saber científico.

4 Desde um ponto de vista lógico e epistemológico, classifica estas teorias em dois grupos principais: metodologias justificacionistas e pragmático-convencionalistas (Lakatos,1987a). 
saldo de que "todas as teorias são igualmente indemonstráveis". Contra o ideal reformado do "neojustificacionismo" (como o do empirismo lógico) de um conhecimento "provável" e de uma honestidade a exigir a especificação da probabilidade de qualquer hipótese à luz da evidência empírica disponível, valeu a crítica de Popper, segundo a qual "todas as teorias são igualmente improváveis" (Lakatos, 1979 e 1987a) ${ }^{5}$.

Popper especifica um novo conjunto de decisões metodológicas, o do falseacionismo, em cujos termos uma teoria é científica - distinta de uma teoria da metafisica, lógica ou matemática - apenas se falseável em contraste com um "enunciado básico fatual" (estabelecido como tal por convenção) e se capaz de predizer fatos novos e inesperados. De acordo com suas concepçóes epistemológicas (Popper, 1975 a e b), retratadas em seu método da discussão crítica (racional) de teorias, o conhecimento progride por conjeturas e refutações, atendendo aos seguintes padrōes de cientificidade: formulação clara de um problema; invenção de uma teoria que procura resolvê-lo e que seja falseável, embora não tenha sido ainda falseada (ou de teorias que concorram para tanto); discussão crítica desta(s) teoria(s), centrada na tentativa de seu falseamento, com elaboração e refino de testes críticos (experimentos cruciais); afastamento definitivo da teoria falseada, gerando um novo problema; invenção de uma nova teoria que preserve as conseqüências aceitáveis da anterior, corrija seus erros e faça predições novas, exibindo, deste modo, "um conteúdo crescente (excedente)"; no caso de teorias concorrentes que ainda não tenham sido falseadas, apesar do insistente refinamento de testes críticos (experimentos cruciais) a que sejam igualmente submetidas, será preferivel ("melhor", num dado tempo) aquela que tiver maior grau de corroboração (esteja "mais próxima à verdade") e que, sendo falseada, gere problemas mais interessantes, o que aponta, novamente, à teoria com maior abrangência de conteúdo. Em conseqüência, será contrário a seu código de honra propor teorias que não sejam falseáveis ou hipóteses ad hoc (Lakatos, 1987a). Segundo a sua ontologia dos "3 mundos" - "mundo 1", dos objetos físicos; "mundo 2", dos estados da consciência subjetiva; "mundo 3", das descrições objetivas, dos argumentos, das teorias com seus conteúdos objetivos -, o conhecimento científico pertence à esfera do "conhecimento objetivo", correspondente ao "mundo 3".

5 Em especial, em Lakatos, 1979:113-115 e 149-150 e em Lakatos, 1987a:13 e 19. Lakatos também enaltece a crítica ao indutivismo feita por Pierre Duhem, destacado entre os convencionalistas. (Lakatos, 1987a:57). Inscrevendo Popper no âmbito do "convencionalismo revolucionário", Lakatos ressalta igualmente sua crítica ao ideal convencionalista de simplicidade intuitiva. 
Lakatos vê sua proposta na trilha do racionalismo popperiano, substituindo o problema dos fundamentos pelo do crescimento crítico-falivel do conhecimento científico (Lakatos, 1979), atento à questão de seu crescimento contínuo e avaliando as teorias pelo seu conteúdo objetivo (Lakatos, 1979), ao invés de ater-se a questões subjetivas, de natureza sociopsicológica (Lakatos, 1979 e 1987a). Segundo ele, a ruptura formulada por Popper entre conhecimento objetivo ("mundo 3 ") e suas distorções refletidas nas mentes individuais ("mundo 2") "abriu o caminho para minha demarcação entre história interna e externa" (Lakatos, 1987a:24-5). Contudo, contra o que seria o falseacionismo ingênuo presente na análise feita por Popper ${ }^{6}$, mostra que o ideal de um conhecimento "conclusivamente refutável" também revela-se insustentável, sendo questionáveis as distinções em que se apóia, tal como "obsenvacional/teórico", sua doutrina da prova observacional ou experimental, supondo que proposições "derivem-se" de fatos, e seu critério de cientificidade das teorias em termos de "refutabilidade" ( $x$ tenacidade) fatual. Mesmo o ideal de "conhecimento falseável" vê-se atingido, face às dificuldades que cercam o estabelecimento dos critérios para demarcação de "problemático/não-problemático" (todas as explicações supõem um fundo "não-problemático", isto é, que não é trazido à discussão e encontra-se implícito em nível das teorias de obsenvação, determinado por "teorias interpretativas", que fornecem a evidência para as "teorias explicativas"), à impossibilidade de testar severamente a cláusula ceteris paribus e à legitimidade lógica e empírica de um processo de apelação, em que seja questionado o "fundo não-problemático" (Lakatos, 1979) ${ }^{7}$. As decisões metodológicas do falseacionismo ingênuo não passam pelo teste da história das ciências - "falseamentos célebres", ou se revelam claramente irracionais, ou se apóiam em princípios de racionalidade radicalmente diferentes (Lakatos, 1979).

Optando pela segunda alternativa, Lakatos defende a idéia de uma racionalidade não instantânea, historicamente (re)construída, revelada em sua metodologia dos programas de pesquisa, a favor de um falseacionismo metodológico sofisticado. Do convencionalismo, toma a liberdade racional de aceitar por convenção não apenas enunciados fatuais espaço-temporalmente singulares, mas teorias espaço-temporalmente universais (Lakatos, 1987a), dispensando estratagemas convencionalistas para a proteção de qualquer tipo de enunciado, dado

6 Todavia, sua avaliação da lógica da descoberta científica de Popper e, assim, de seus débitos para com ela, não é de todo clara. Lakatos (1979) vê aí fundidas duas posições diferentes: a de um falseacionismo metodológico ingênuo, alvo de suas críticas, e a de uma versão mais sofisticada deste falseacionismo, que Lakatos apresentará em sua própria posição. Entretanto, admite que "Popper nunca fez uma distinção nítida entre o falseacionismo ingênuo e o sofisticado" e que "o verdadeiro Popper nunca abandonou suas primeiras (ingênuas) regras de falseamento" (Lakatos, 1979:224-225). Em especial, em Lakatos, 1979 :118-124;155-156. 
que todos tornam-se problemáticos. Considerando o caráter histórico e complexo do falseamento e a possibilidade da ciência crescer sem refutações, reduz os elementos convencionalistas do falseacionismo ingênuo, contidos no estabelecimento de qual seja o conjunto (distinto) dos "enunciados básicos" (que inclui os "falseadores potenciais") e de quais sejam os enunciados singulares "não-falseáveis"; de quais sejam as regras para a rejeição da evidência, para a não proteção contra o falseamento e para a rejeição de teorias que não possam ter "falseadores potenciais" (Lakatos, 1979). Mesmo que não possam ser eliminadas convenções quanto à "base empírica", estas podem, segundo Lakatos, ser melhoradas (podem ser trazidas à controvérsia racional, a um exame das razões para sua adoção) ${ }^{8}$.

Os critérios de avaliação que propõe referem-se antes a séries de teorias estruturadas num programa, dotado de um núcleo, que inclui o componente metafísico, a idéia diretora e "irrefutável" que o caracteriza e move, desenvolvido através de suas heurísticas positiva e negativa. A heuristica negativa estabelece que caminhos devem ser evitados, visando a preservação do núcleo - estabelece a formação de um "cinto de proteção", pela articulação e/ou invenção de hipóteses auxiliares; redirige o modus tollens ao "cinto de proteção", procedendo a ajustes ou à substituição total do "cinto". A heurística positiva diz respeito à política de pesquisa a ser seguida - sugestões sobre como modificar e sofisticar o "cinto" refutável, incluindo a construção e complexificação de uma "cadeia de modelos" sucessivos, sendo esperada e antecipada a existência de "refutaçóes", bem como a estratégia para digeri-las. São as "verificações" (e não as "refutações") que mantêm o programa, a ser avaliado em função da transferência progressiva de problemas. À luz deste critério, uma série de teorias é progressiva, quando teórica e empiricamente progressiva; teoricamente progressiva, quando cada nova teoria tem algum excesso de conteúdo empírico (prediz fatos novos, em relaço à sua predecessora); empiricamente progressiva, quando parte do conteúdo empírico for corroborado; degenerativa, quando não for progressiva. A aceitabilidade de um programa requer que exiba, pelo menos, transferência teoricamente progressiva de problemas. Programas são rejeitados por outros programas, com os quais competem, em vista de sua força heurística - capacidade para produzir fatos novos, explicar refutações no decorrer do crescimento e, quando possível, estimular a matemática (Lakatos, 1979).

8 Lakatos acusa Popper de nunca ter oferecido uma teoria de crítica racional das convenções metodológicas consistentes (Lakatos, 1987a). Consentindo num processo de apelação, o problema deixa de ser o da substituição de uma teoria refutada por fatos, mas o da resolução de incompatibilidades entre teorias intimamente associadas, "interpretativa" e "explicativa". Substituindo a exigência de "refutabilidade" pela de "transferência progressiva de problemas", como veremos a seguir, fica eliminada a decisão de rejeitar teorias que não possam ter "falseadores potenciais"; uma teoria sintaticamente metafísica (irrefutável) pode produzir uma “transferência progressiva de problemas” (Lakatos, 1979). 
Tais avaliações, entretanto, não são instantâneas, nem de aplicação mecânica ${ }^{9}$. Tanto a novidade de uma proposição fatual como as avaliações de casos "corroboradores" e "falseadores" são sempre retrospectivas e a evidência contrária a uma teoria será sempre corroboradora de outra. Incompatibilidades geralmente surgem com a expansão dos modelos: "Não se trata de propormos uma teoria e a Natureza poder gritar NÃO; trata-se de propormos um emaranhado de teorias e a Natureza poder gritar INCOMPATÍVEIS" (Lakatos, 1979:159). E "alguns dos maiores programas de investigação científica progrediram sobre fundamentos inconsistentes" (Lakatos, 1987a:52). Ao longo do processo, uma experiência pode, de início, ser um enigma de rotina, tornar-se uma quase "experiência crucial" e retornar a um enigma de rotina, e a "experiência crucial" pode transformar-se de uma derrota numa vitória. Programas podem superar fases degenerativas - a guerra só está perdida para um programa se, após um esforço sustentado, não se verifica reabilitação. A engenhosidade humana e a legitimidade de um "processo de apelação" podem reverter a sua condiçãa ${ }^{10}$. Assim, o código de honestidade científica estabelecido pela metodologia dos programas de pesquisa de Lakatos recomenda a modéstia: "nem a prova de inconsistência por parte do lógico, nem o veredito de anomalia por parte do cientista experimental podem anular um programa de pesquisa de um só golpe. Só se pode ser adivinho depois do acontecido" e "as razões das partes rivais devem ser lembradas sempre e publicamente expostas" (Lakatos, 1987a:30).

Atendida a regra metametodológica de que uma teoria da racionalidade científica deverá concordar com os "juízos de valor básicos da elite científica"11, as diferentes teorias da racionalidade poderão ser criticamente comparadas, à luz das reconstruções racionais da ciência a que dão lugar, fruto das diferentes demarcações que estabelecem entre o normativo-interno (esfera lógico-epistemológica), em cujos termos o historiador reconstrói a história interna ${ }^{12}$, omitindo

9 Em uma nota de pé de página, defendendo-se de crítica que lhe é feita por Kuhn e Feyerabend, Lakatos apela à necessidade - de resto presente, segundo ele, em todas as metodologias - de nos valermos do "senso comum" (isto é, de juízos de casos particulares que não se fazem segundo regras mecânicas, mas que apenas seguem princípios que deixam algum Spielraum)" para aplicação das regras (Lakatos, 1987a:p. 36-37, nota 58).

10 "A direção da ciência é determinada principalmente pela imaginaço criativa humana e não pelo universo de fatos que nos cercam. A imaginação criativa tem probabilidades de encontrar uma nova evidência corroboradora até para o programa mais "absurdo", se a busca for convenientemente orientada. Essa busca de uma nova evidência corroboradora é perfeitamente permissível" (Lakatos, 1979:p. 2.33).

11 Lakatos admite que o código universal de leis do filósofo possa contradizer a autoridade da elite científica na aplicação de seus juízos em situações tais como a de uma tradição que se encontre estagnada ou de formação de uma tradição inaceitável (Lakatos, 1987a:p. 71).

12 Privilegiada por Lakatos (1987:11) como a que oferece uma explicação racional do desenvolvimento do conhecimento objetivo. 
"tudo o que seja irracional à luz de sua teoria da racionalidade" (Lakatos, 1987a:40), e o empírico-externo (esfera sociopsicológica). Diz Lakatos:
A idéia básica de tal crítica é que todas as metodologias fun- cionam como teorias (ou programas de investigaço) historio- gráficas (ou meta-históricas) e podem ser criticadas, critican- do-se as reconstruções históricas racionais a que conduzem" (Lakatos, 1987a:45-46).
Quando aparece uma teoria da racionalidade melhor, a história interna pode ampliar-se e reclamar terreno à histó- ria externa. (Lakatos, 1987a:66).

Aplicando, em um nível metametodológico, os critérios de avaliação propostos pela metodologia dos programas de pesquisa, Lakatos ressalta que, enquanto as demais teorias da racionalidade examinadas revelam-se historicamente falseadas - mesmo a popperiana, em que pese a superioridade das suas reconstruções (Lakatos, 1987a) - , a sua satisfaz o requisito de um programa de investigação historiográfica "progressivo", com a crescente descoberta de fatos históricos novos, ampliando a racionalidade da história da ciência ${ }^{13}$, mostrando como perfeitamente racionais desenvolvimentos tidos como irracionais até pela teoria de Popper $^{14}$. Certamente, persistem anomalias nas suas reconstruçōes. Mas é parte da racionalidade de sua própria teoria que não se deva ou possa explicar toda a história como racional, pois "a história da ciência é sempre mais rica do que sua reconstrução racional" (Lakatos, 1987a:38); que a história interna não seja, "exatamente, uma seleção de fatos metodologicamente interpretados: pode ser, em certas ocasiões, uma versão radicalmente modificada dos mesmos" (Lakatos, 1987a:p.40) e que deva ser complementada com a história externa. Fiel ao princípio de que uma História da Ciência sem uma filosofia da ciência é cega e uma Filosofia da Ciência sem a história da ciência é vazia, a metodologia que propõe "especifica métodos para que o filósofo da ciência aprenda do historiador da ciência e vice-versa", trazendo uma nova racionalidade, divergindo tanto dos que supõem "que os standards científicos gerais são imutáveis e que a razão pode descobri-los a priori, como daqueles que pensam que a luz da razão ilumina apenas casos particulares". (Lakatos, 1987a:71)

Sumarizando, a racionalidade de Lakatos define-se nos padrões de sua "lógica da descoberta científica", cujo estabelecimento supõe, na esteira da "tradição"

13 Privilegiada por Lakatos (1987a:11) como a que oferece uma explicação racional do desenvolvimento do conhecimento objetivo.

14 "Onde Kuhn e Feyerabend vêem mudanças irracionais, eu predigo que o historiador poderá provar que houve mudança racional" (Lakatos, 1987a:64). 
racionalista: (a) uma intrínseca racionalidade da ciência, e, assim, a possibilidade de reconstruí-la e de avaliá-la quanto aos resultados encontrados, atribuídos ao seu operar através de razões objetivas, enquanto relações lógicas e determinações empíricas referentes ao "conteúdo" exibido por teorias e programas, legitimamente alegadas a favor da aceitabilidade destes; (b) a contraposição destas razões objetivas à subjetividade dos fatores de natureza sociopsicológica ${ }^{15}$. Racional restringe-se, assim, ao que Lakatos chama de história interna e cuja esfera busca ampliar, em detrimento da "irracionalidade" da esfera da história externa. Diferentemente, porém, das abordagens tradicionais, a nova racionalidade de Lakatos é construída ao longo de um processo histórico, do qual fazem parte inconsistências (ainda que "temporárias"), refutações, corroborações, a transformação de refutações em corroborações e vice-versa, um núcleo condutor metafísico ${ }^{16}$ e onde joga papel central a imaginação criativa, sem uma metodologia de caráter prescritivo: "minha 'metodologia' (...) apenas avalia teorias ou programas de investigação completamente elaborados, mas não se propõe a aconselhar o cientista sobre como chegar a teorias adequadas, nem sobre qual de dois programas rivais deveria continuar empregando" (Lakatos, 1987b:145). Embora permitaIhe julgar as decisões tomadas pelos cientistas ${ }^{17}$, admite, contrariamente a Popper, que eles freqüentem e racionalmente ignorem contra-exemplos, apeguem-se dogmaticamente a um programa, mesmo estagnado, operem enxertos com fundamentos incompatíveis; seria irracional tanto louvar o anarquismo como virtude e defender malformações depois de encerrada a fase progressiva de um programa, quanto sustá-lo até resolver incompatibilidades (Lakatos, 1979).

A flexibilidade dos padrões lakatianos, que permite abranger um amplo elenco de comportamentos, tornando-os "racionais", dá margem, porém, a certos questionamentos. Kuhn, Feyerabend e Musgrave (e também Richard Hall) criticam-lhe a ausência de um critério que permita claramente estabelecer quando um programa deixa de ser progressivo e torna-se estagnado ${ }^{18}$, quando deixa de ser racional apegar-se a ele, dado que um programa em degeneração "pode", em princípio, "sempre" recuperar-se. A resposta que Lakatos oferece tangencia o problema mas não dirime - acusa Feyerabend e Kuhn de confundirem a avalia-

15 Contudo, Lakatos refere-se a uma "razão racional" (1979:172). Admitiria ele uma razão "não-racional"?

16 Além de sua presença como núcleo condutor do programa, o componente metafísico impõe-se na forma de um princípio extrametodológico que possa transformar a ciência de mero jogo (conjunto de táticas brilhantes e céticas) em exercício epistemologicamente racional, em "aventura falível, mais séria, de aproximação à Verdade do Universo" (Lakatos, 1987 a:31).

17 "Qualquer coisa que façam, posso julgá-los: posso dizer se progrediram ou não" (Lakatos, 1987 b: 152).

18 Lakatos dedica a esta objeção de Kuhn e Feyerabend e à sua resposta uma nota extensa (1987 a:36-37). Para mais detalhes sobre as objeções de Hall, ver Hall, 1987 e a resposta de Lakatos em Lakatos, 1987b: 156. 
ção metodológica de um programa com sua heurística firme. Serve, contudo, para discutir alguns pontos desta metodologia. Esclarece em que sentido sua racionalidade tem a ver com padrões de honestidade intelectual - é possível aderirse racionalmente a um programa estagnado e mesmo vencido, mas não se deve negar publicamente sua informação:

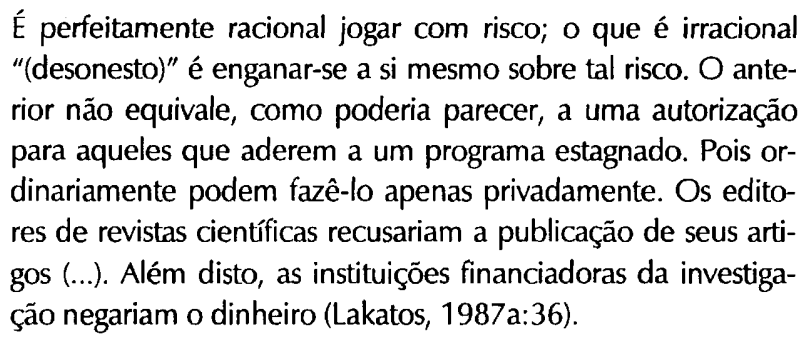

Nesta elucidação, deixa entrever em que medida sua metodologia abre espaço para que, "desde um ponto de vista prático", como dirá Feyerabend (Feyerabend, 1977, cap.XVI), seus padrões ganhem força coercitiva sobre o como agir do cientista, evitando que se crie aquela aparência considerada por Lakatos como "não autorizada".

Lakatos parece, de algum modo, minimizar tal intromissão da coerção prática em seus padrões de racionalidade, dizendo não defender que aquelas decisões institucionais sejam incontrovertíveis e destacando o papel do senso comum na aplicação das regras de metodologias não-mecânicas a casos particulares. Com isto, porém, dá lugar à acusação, feita por Feyerabend, de valer-se de ambigüidades semânticas, trabalhando com distintos conceitos de racionalidade, passando do liberalismo, em princípio, da racionalidade da metodologia dos programas de pesquisa ao conservadorismo, em princípio, da racionalidade do senso comum, sem avisar ao leitor (Feyerabend, 1977, cap.XVI). Em qualquer caso, posto que (a) a racionalidade de Lakatos pretende aplicar-se à avaliação de programas já existentes e de decisões que foram tomadas pelos cientistas em sua adesão ou não aos mesmos, dependendo desta adesão o desenvolvimento sem o qual um programa não poderá ser julgado progressivo, estagnado ou degenerado, e que (b) esta decisão está sujeita a pressões institucionais psicológicas e sociológicas e a crenças do "senso comum", fatores que pertenceriam à história externa, à esfera subjetiva, irracional, (c) como ficam as distinções entre história interna/história externa, objetivo/subjetivo e a alegada racionalidade da mudança científica? 
No que concerne à primeira, Kuhn (1987) alega que os critérios de Lakatos violentam o uso geral, restringindo a história interna a apenas uma parte do que usualmente se compreende sob este âmbito ${ }^{19}$, excluindo fatores que interferem na escolha, produção e defesa de uma dada teoria e colocando o método metametodológico que apregoa em risco de reduzir-se a uma tautologia. Resumindo sua crítica, diz que "o que Lakatos concebe como história não é história, mas filosofia que inventa exemplos" (Kuhn,1987:89), o filósofo só aprendendo dela o que nela previamente introduza ${ }^{20}$. Hall, por sua vez (Kuhn,1987:115), critica a visualização de uma linha divisória suficientemente precisa entre história da ciência interna e externa, cujo traçado dependeria do conhecimento de "pelo menos o conjunto total das crenças do cientista em questão" .

A referência aos juízos básicos de valor da elite científica (com os quais devem concordar as reconstruções racionais constitutivas da história interna) também enseja considerações críticas. Feyerabend examina os particulares dados históricos selecionados por Lakatos e o modo como privilegia os juízos que perfazem o "saber científico geral" pós-século XVII (Feyerabend, 1977, cap.XVI). Estes juízos não seriam tão uniformes e raramente se prenderiam a boas razões. A reconstrução racional de um determinado programa refletiria antes a "ideologia profissional daquele domínio 21 , oculta sob o alegado "saber científico geral", requerendo este, para seu exame nos termos das razões de Lakatos, a reconstrução da "disciplina correta" (e não de programas isoladamente) e a discussão da ideologia profissional científica frente a outras ideologias profissionais, bem como da ideologia da ciência moderna frente à da ciência aristotélica para compreendermos a "mudança" ocorrida ${ }^{22}$. Segundo Feyera-

19 Usualmente, lembra Kuhn, a história interna "centra-se primária ou exclusivamente sobre as atividades profissionais dos membros de uma comunidade científica particular" e a externa "considera as relações entre tais comunidades científicas e o resto da cultura" (1987:85).

20 Esta crítica, contudo, deve ser tomada com uma certa reserva. Lakatos admite que a história como um todo é mais rica que a "história interna" e que a maior ou menor capacidade de uma filosofia normativa cumprir com o papel a que se propõe pode ser medida em termos da maior ou menor "racionalização" que permita operar na história como um todo. Já Kant dizia que "a razão só vê o que ela mesma produz segundo seu projeto" (Kant, 1974:p. 11).

21 Por exemplo, a maioria dos cientistas os aceita curvando-se à autoridade dos colegas especialistas. Ao ver de Feyerabend, Lakatos está consciente desta dificuldade e para tanto admite aquelas situações em que o estatuto do filósofo deverá impôr-se ao juízo da comunidade científica.

22 Conforme destaca Feyerabend (Feyerabend, 1977, cap. XVI), a ciência aristotélica tinha seus juízos consistentes com o estatuto filosófico (da filosofia aristotélica), condição apregoada por Lakatos como orientadora em períodos de dificuldades especiais. No embate entre aristotélicos e modernos, os primeiros estavam se saindo bem, enquanto os modernos viram-se às voltas com problemas, como será referido adiante, no seu estudo do caso de Galileu. 
bend, Lakatos não se ocupa com estas tarefas, que revelariam a "função da propaganda, do preconceito, da ocultação e de outros procedimentos irracionais na gradual resolução de problemas. Todos estes são fatores 'externos', no esquema de Lakatos". (Feyerabend, 1977:314)

Kuhn, de sua parte, ressalta que as referências de Lakatos a "informação pública" e "código de honra" sugerem ser a eleição de teorias antes uma atividade de valores que de regras comunitárias. E, sendo os juízos básicos de valor juízos da comunidade científica, a condição de racionalidade admitida por Lakatos parece vir ao encontro da racionalidade advogada por Kuhn e que Lakatos chama de "psicologia das multidões" (Lakatos, 1979:221):

O comportamento científico, tomado em seu conjunto, é o melhor exemplo que possuímos de racionalidade. A opinião do que seja racional depende, de modo significativo, (...) do que sejam considerados aspectos essenciais do comportamento científico. (...) se (...) o desenvolvimento da ciência depende essencialmente do comportamento que previamente designamos como racional, então dever-se-ia concluir não que a ciência seja irracional, mas que nossa noção de racionalidade necessita ser revisada a todo o momento (Kuhn, 1987:91).

Por fim, cabe obsenvar que Lakatos assume a distinção objetivo/ subjetivo nos termos em que a apresenta, sem discuti-la. O que faz com que razões lógicas e empírcas, atinentes a "conteúdos" de teorias, pertençam ao primeiro e fatores sociopsicológicos ao segundo? O que, a rigor, os distingue, de sorte que ao primeiro cabe associar a racionalidade e não ao segundo? $O$ que faz do primeiro, e não do segundo, fonte de respostas legítimas à questão: por que foi esta teoria aceita (ou rejeitada)? Critérios como "consistência lógica", "graus de corroboração" teriam o caráter de boas razões, se não fossem assim valorizados por indivíduos, comunidades e se não tivessem "eficácia material", a usar uma expressão de Feyerabend (1977, cap. I e 1987, Ciência como arte), em seu comportamento?

\section{A CRÍTICA DE FEYERABEND AO "RACIONALISMO"}

Em sua crítica, Feyerabend identifica o racionalismo com uma tradição que nasceu na Grécia e inicialmente "substituiu os conceitos ricos e dependentes da situação, próprios da épica primitiva, por umas poucas idéias abstratas e independentes da situação", gerando, numa segunda etapa, "estórias especiais, logo chamadas de 'provas' ou 'argumentos', cuja trama não é imposta aos caracteres principais, mas 'segue-se de' sua natureza." Desenvolveu-se, assim, igualmente, a 
idéia de que "são as próprias coisas que produzem a estória e a dizem 'objetivamente', isto é, independentemente das opinióes e das compulsões históricas." A pressão conjunta destes dois desenvolvimentos afiançou "o critério de que o conhecimento é único - de que existe apenas uma estória aceitável: a 'verdade' - abstrato, independente da situação ('objetivo') e baseado em argumento' (Feyerabend, 1987:9). Endereça sua crítica, em especial, ao desenvolvimento mais recente desta tradição, ao racionalismo crítico de Popper, estendendo-a ao racionalismo de Lakatos, na sua versão conservadora. Sob este enfoque, podemos entender a razão criticada por Feyerabend como a faculdade pela qual os padrões de tal tradição se exercem, traduzindo-se em obediência a regras fixas e a padrões imutáveis, estabelecendo e submetendo-se a algo como " $\mathrm{O}$ " método, concentrado nas seguintes regras: 1 . Só aceitar hipóteses que se ajustem a teorias confirmadas ou corroboradas e 2. Eliminar hipóteses que não se ajustem a fatos bem estabelecidos, expressando, segundo Feyerabend, a "essência do empirismo" e do indutivismo (Feyerabend, 1977, caps. I e II) ${ }^{23}$.

Em tal modo de conceber, o elenco do que cabe considerar razões daquilo que é estabelecido ou arrolado pela razão (faculdade) ao contar aquela estória ou desenvolver aquele 'argumento', restringe-se ao que vem circunscrito pela observância daquelas regras. Opõem-se a fatores "não-justificados" (pela 'prova', pelo 'argumento'), tanto "subjetivos" quanto "circunstanciais", dependentes do contexto em que se constitui a elaboração e defesa de uma dada teoria e que fogem ao escopo daquelas regras fixas, com o qual se associaria o desiderato de $o b$ jetividade. Ao criticar a eficácia de tais regras para dar conta da condução da ciência, Feyerabend igualmente critica a eficácia do proceder por "razões" para tal fim. De modo similar, critica a racionalidade, enquanto marca característica daquela tradição e a teoria estática da racionalidade a que esta concepção dá lugar:

E como regras e padrões são usualmente tomados como constituintes da 'racionalidade', infiro que episódios famosos na ciência, admirados por cientistas, filósofos do mesmo modo que por pessoas comuns, não foram 'racionais', não ocorreram de uma maneira 'racional', a 'razão' não foi a força motora por detrás dos mesmos e eles năo foram julgados 'racionalmente' (Feyerabend, 1978:14).

23 Assim, em que pesem as críticas de Popper ao indutivismo, podemos ver que compartilha o empirismo deste, ao tomar a experiência como "o" árbitro para a aceitabilidade (via "falseamento") de nossas teorias. Deste modo, podemos entender que Feyerabend chame o procedimento que se oponha àquelas regras e aos preceitos do próprio racionalismo crítico de contra-indução. 
Desacredita, assim, a imponência de uma teoria da ciência que aponte a tais padrões e regras e se pretenda autorizada por alguma teoria da racionalidade do fazer cientíico (Feyerabend, 1987), com crítica explícita a seu enfoque estático: "a idéia de um método estático ou de uma teoria estática da racionalidade funda-se numa concepcão demasiado ingênua do homem e de sua circunstância social" (Feyerabend, 1977:34) ${ }^{24}$.

Embora parta de uma discussão da racionalidade enquanto embutida na questão da análise da ciência, projeta seu exame na perspectiva de uma rede de pressupostos epistemológicos, ontológicos, antropológicos e pedagógicos, que excedem a pauta metodológica de Lakatos. Vê o mundo que desejamos explorar como uma entidade em grande parte desconhecida; a ciência construída em seu acesso como um modo de conceber esta entidade, de dar-the sentido, admitindo que a coisa e a compreensão de uma idéia correta dessa coisa "são, muitas vezes, partes de um único e indivisivel processo" (Feyerabend, 1977:32), não havendo "fatos nus", estando sempre sujeitos à "contaminação" fisiológica e histórico-cultural da evidência (Feyerabend, 1977, cap.V), tomando a História como um labirinto de interações, e propondo que a educação científica de seus atores seja conciliada com uma "atitude humanista", libertadora, de vida completa e gratificante, junto à "tentativa correspondente de descobrir os segredos da natureza e do homem" (Feyerabend, 1977:p.22). Esta rede de pressupostos faz-se presente na concepção de conhecimento que Feyerabend oferece:

O conhecimento (...) não é um gradual aproximar-se da verdade. $\dot{E}$, antes, um oceano de alternativas mutuamente incompatíveis (e, talvez, até mesmo incomensuráveis), onde cada teoria singular, cada conto de fadas, cada mito que seja parte do todo força as demais partes a manterem articulação maior, fazendo com que todas concorram, através deste processo de competição, para o desenvolvimento de nossa consciência. Nada é jamais definitivo, nenhuma forma de ver pode ser omitida de uma explicação abrangente (...) (Feyerabend, 1977:40-41),

refletindo-se na sua análise da ciência:

a história da ciência se faz porção inseparável da própria ciência - essencial para seu posterior desenvolvimento, assim

24 O texto de Contra o Método que serviu de guia para o presente capítulo é aquele com o qual nosso leitor encontra-se mais familiarizado, publicado em nosso meio pela editora Livraria Francisco Alves. Trata-se de uma tradução da edição inglesa de Against Method publicada em 1975. Para a presente edição de Filosofia, Sociologia e História das Ciências I, foram introduzidas revisões no texto original deste capítulo, incorporando as alterações ou elucidações mais significativas trazidas pelas edições inglesas de Against Method de 1988 e 1993. A de 1988 foi editada em língua portuguesa pela Relógio D’Água, Lisboa, 1993. 
como para emprestar conteúdo às teorias que encerra em qualquer momento dado. (...) A tarefa do cientista não é mais a de 'buscar a verdade' ou a de 'louvar a Deus'ou a de 'sistematizar observações' ou a de 'aperfeiçoar previsões '. Esses são apenas efeitos colaterais de uma atividade para a qual a sua atenção se dirige diretamente e que é 'tornar forte o argumento fraco', tal como disse o sofista, para, desse modo, garantir o movimento do todo (Feyerabend, 1977:40-41).

Diferentemente de Lakatos, Feyerabend não pretende fornecer uma nova metodologia ou uma nova teoria da racionalidade. Seu objetivo é convencer o leitor de que "todas as metodologias, mesmo as mais óbvias, têm limitações" (Feyerabend, 1977:43), mostrando a razoabilidade, ainda que não exclusividade, da contra-indução, ou seja, das contra-regras (opostas às regras do racionalismo): 1. Introduzir hipóteses que conflitem com teorias confirmadas ou corroboradas e 2. Introduzir hipóteses que não se ajustem a fatos bem estabelecidos. Caso não possamos resistir à tentação de buscar um princípio (metametodológico) que seja aplicável a todas as situações (ou contextos), concede que o único seria o princípio tudo vale (Feyerabend, 1977, cap. I) ${ }^{25}$.

Feyerabend identifica sua posição a favor de uma metodologia pluralista com o que chama de anarquismo epistemológico, que diz diferir tanto do ceticismo quanto do anarquismo político (religioso). Ao anarquista epistemológico, não lhe é indiferente um ou outro enunciado e desejará, talvez, defender certa forma de vida combatida pelo anarquista político ou religioso, mantendo ou alterando seus objetivos e estratégias, na dependência do argumento, do tédio, de uma experiência de conversão ou de outros fatores de ordem emocional e de força persuasiva, não se recusando a examinar qualquer concepção, admitindo que, por trás do mundo tal como descrito pela ciência, possa ocultar-se uma realidade mais profunda, ou que as percepções possam ser dispostas de diferentes maneiras e que a escolha de uma particular disposição "correspondente à realidade" não será mais "racional" ou "objetiva" que outra (Feyerabend, 1977, cap. XVI).

25 Não cabe, aqui, a crítica de que este princípio seria autodestrutivo, uma vez que, entendido como um metaprincípio, poderia compreender sob si o princípio nem tudo vale como princípio de ordem inferior, atinente a um particular contexto, ao passo que tudo vale seria o único princípio que se aplicaria a todos os contextos.Cabe ressaltar que a análise feita por Feyerabend, com a crítica que elabora contra o "racionalismo" não depende da prévia aceitação desse ou de qualquer outro princípio que fosse universalmente válido, não pretendendo uma nova "teoria da ciência" ou da "racionalidade". No prefácio à segunda edição inglesa de Against Method, reproduzido na terceira edição, Feyerabend diz (1993:7): (...) 'tudo vale' não é um princípio que eu defendo - não penso que princípios possam ser usados e frutiferamente discutidos fora da situação concreta de pesquisa que se espera que eles afetem - mas a aterrorizada exclamação de um racionalista que olha mais de perto a história. Lendo as muitas críticas exaustivas, sérias e completamente desorientadas que recebi após a publicação da $l^{1}$ edição inglesa, frequientemente me lembro de minhas trocas com Imre, o quanto ambos teríamos rido se fôssemos capazes de ler essas efusōes juntos. 
Antes que um ideário, o anarquismo epistemológico é uma atitude refletida na própria estratégia utilizada por Feyerabend em sua defesa e na crítica ao racionalismo, desenvolvida em duas frentes que se completam e mutuamente se suportam. De um lado, Feyerabend busca implodir a posição do adversário. Lutando em seu campo e com as suas armas, mostra "a irracionalidade do racionalismo", uma vez que suas regras, levadas às suas últimas conseqüências, dentro da própria esfera lógica e epistemológica em que se alicerçam, tornam-se autodestrutivas, inviabilizam o alcance de seus objetivos e conflitam com os fundamentos que as suportam ${ }^{26}$. Dada a "contaminação" histórica e fisiológica da evidência - admitida mesmo para as posiçóes racionalistas como as de Popper e de Lakatos -, a condição de coerência encerrada na regra 1 impede a exploração da evidência, alimenta uma visão conformista e dogmática, de preservação do status quo e supõe uma autonomia da própria experiência frente à teoria, enquanto " $\mathrm{a}$ " medida para seu conteúdo empírico (Feyerabend, 1977, cap. III). A regra 2, por sua vez, se observada, diz Feyerabend que nos deixaria sem qualquer teoria, dado o desacordo tanto quantitativo como qualitativo que toda a teoria exibe com relação aos fatos de seu domínio. Para avaliar tais discordâncias, bem como permitir a exploração da evidência, escavando as ideologias subjacentes (Feyerabend, 1977, cap. V), e a discussão crítica de teorias, toma-se indispensável o trabalho com alternativas teóricas conflitantes - "não podemos descobrir o mundo a partir de dentro. Há necessidade de um padrão externo de crítica: precisamos de um conjunto de pressupostos alternativos" (Feyerabend, 1977:42).

De outro lado, Feyerabend mostra a "razoabilidade do irracionalismo", viabilizando o progresso da ciência, em qualquer uma das acepções que lhe seja emprestada (Feyerabend, 1977, cap.II), enquanto suas contra-regras são necessárias à exploraço da evidência e discussão crítica pretendidas pelas regras do racionalismo e mostram-se "corroboradas" pela práxis científica, tal como pode ser visto no seu estudo de caso ${ }^{27}$ sobre a defesa da doutrina copernicana e introdução de uma nova física por Galileu (Feyerabend, 1977, caps. VI-XIII). Seu estudo revela como a nova teoria, a de Copérnico, admitindo o movimento da Terra, conflitava com teoria e fatos aceitos e bem estabelecidos - a aristotélica, com uma sólida epistemologia e ontologia, e sua bem-sucedida administração do senso comum, provendo-lhe o requerido suporte empírico. A estratégia para a defesa da nova visão demandou a substituiçăo do padrão sensorial e lingüístico-conceitual vigente, atingindo diferentes estratos da experiência, desde uma nova teoria da sensação (que deveria ser acompanhada de "razão") e da percepção (com o uso de um "sentido superior" - o telescópio), até uma nova concepção do movimento e da própria experiência. Consistiu em, primeiro, garantir-lhe espaço, com um movimento inicial de recuo, evitando o confronto direto com a teoria aristotélica e

26 O passatempo favorito do anarquista é "perturbar os racionalistas, descobrindo razões fortes para fundamentar doutrinas desarrazoadas" (Feyerabend, 1977: p. 293).

27 Procedimento coerente com sua recusa em oferecer uma nova teoria da ciência. 
neutralizando o apoio da evidência disponível, apelando não só a argumentos, mas à propaganda, a razões eventuais e procedimentos para os quais Galileu não dispunha de "boas razões", como o uso do telescópio. Posteriormente, os novos padrões orientaram a busca da evidência favorável ao novo sistema, com o desenvolvimento de hipóteses (ciências) auxiliares, novos instrumentos e procedimentos, ao qual serviram recursos "proibidos" pelas regras "do" método, como uso de adaptaçóes ad hoc, afastamento da evidência contrária e privilégio à evidência corroboradora.

Tais recursos e procedimentos ferem os ditames do racionalismo crítico, "a metodologia positivista mais liberal hoje existente" (Feyerabend, 1977:269). Feyerabend contesta cada uma de suas regras metodológicas (Feyerabend, 1977, cap. XV). Alega que, freqüentemente, instituições, idéias e práticas desenvolvem-se a partir de atividades sem importância. A formulação clara do problema é parte daquele processo de mútua clarificação da coisa e da idéia correta da coisa. Comparte as críticas de Lakatos a um princípio estrito de falseamento, a que este chama de falseamento ingênuo. Critica a exigência de conteúdo crescente (excedente) ou de crescimento empírico, atribuindo sua pretensa aferição a uma ilusão epistemológica: "o imaginado conteúdo das teorias anteriores (...) diminui e pode reduzir-se até o ponto de tornar-se menor que o imaginado conteúdo das novas ideologias" (Feyerabend, 1977:276-277), pois, "o aparato conceitual da teoria, que emerge lentamente, logo começa a definir seus próprios problemas, sendo esquecidos ou postos de lado como irrelevantes os problemas, os fatos, as observações anteriores" (Feyerabend, 1977:275), ou trazidos à esfera da nova teoria através de recursos ad hoc, redefinição de termos ou simples afirmação da decorrência de seu núcleo dos novos princípios básicos.

A questão desta "ilusão epistemológica" leva à discussão da incomensurabilidade de teorias ${ }^{28}$, ou seja, de sua incomparabilidade, "pelo menos na medida em que estão em jogo os padrões mais familiares de comparação", notadamente os de comparação das classes de conseqüências (Feyerabend, 1979). A incomensurabilidade está estreitamente relacionada ao significado e depende do modo como sejam interpretadas as teorias científicas. Coloca-se para uma interpretação "realista", que concebe as teorias científicas como pretendendo dizer algo sobre a constituição ontológica do mundo que tomam como objeto de investigação ${ }^{29}$. Feyerabend arrola três teses centrais a favor da incomensurabilidade: a existência de esquemas de pensamento incomensuráveis entre si, de estágios incomensuráveis no desenvolvimento da per-

28 Este é um dos traços mais característicos da análise de Feyerabend e que o aproxima das considerações de Thomas Kuhn (1979), parecendo afastá-lo de Lakatos.

29 Não se colocaria, por exemplo, para uma interpretação “instrumentalista", à luz da qual as teorias são instrumentos para fazer previsões acerca do comportamento de fenômenos (supondo uma linguagem comum de observação). 
cepção e do pensamento no indivíduo (reportando-se a Piaget), de princípios ontológicos condicionantes das ideologias subjacentes a culturas diversas que impedem, tornam sem sentido determinados sistemas conceituais e que agem à base das cosmovisões encerradas nas nossas teorias científicas.

Sob este enfoque ontológico, partilha a concepção de Whorff acerca da linguagem, como "modeladora de eventos", trazendo classificações cosmológicas implícitas. A mera diferença conceitual não é suficiente para tornar duas teorias incomensuráveis. ${ }^{30}$ Para que isto ocorra, o uso de qualquer conceito de uma deve tornar inaplicáveis os conceitos da outra - que tem lugar quando estão em jogo teorias compreensivas, que abrigam diferentes fundamentos ontológicos: "Afinal, supõe-se que uma teoria abrangente envolva também uma ontologia com o propósito de delimitar o que existe e assim delimitar o âmbito dos fatos possíveis e possíveis interrogações" (Feyerabend, 1977:276). E, para empreender sua investigação semântica, Feyerabend propõe que se proceda como um antropólogo ao estudar a cosmologia de uma tribo, que aprende a linguagem e informa-se dos hábitos sociais básicos; investiga as relações destes com outras atividades, mesmo as que pareçam irrelevantes; procura identificar as idéias-chave e, então, entendê-las, interiorizando-as, sem buscar "traduções" prematuras ${ }^{31}$; completado seu estudo com o conhecimento da sociedade nativa e de seu próprio desenvolvimento pessoal, pode estabelecer comparações entre, por exemplo, o modo de pensar europeu e o nativo e decidir acerca da possibilidade de reproduzi-lo na linguagem ocidental (Feyerabend, 1977, cap. XVII).

Embora Lakatos mantenha a exigência popperiana de crescimento empírico, na forma da transferência progressiva de problemas, não é simples estabelecer em que medida este exame da ilusão epistemológica do crescimento empírico e da questão da incomensurabilidade afasta a análise de Feyerabend da posição de Lakatos. De um lado, há uma comensurabilidade advogada por Lakatos - traço comum às propostas racionalistas -, estabelecida por padrões para avaliação da racionalidade da mudança científica, repercutindo na sua crítica à irracionalidade que atribui às visões de Kuhn e de Feyerabend acerca da mudança científica. De outro, o teor de suas críticas ao falseamento popperiano, bem como a admissão de que cada programa tem seu núcleo (metafísico) condutor, o que sugere uma delimitação própria de fatos, problemas e padrões de soluções, abandonam o curso tradicional da abordagem da comensuração. Se o crescimento empírico exigido por Lakatos for avaliado na perspectiva das transfor-

30 Feyerabend, em nota de pé-de-página (1981:154), diz que Kuhn ocasionalmente descuida deste ponto.

31 Feyerabend refere-se igualmente à aprendizagem da língua materna pela criança, ou mesmo ao seu aprendizado de outras línguas, não se processando via "tradução", e pergunta-se, então, por que os adultos também não poderiam aprender ou penetrar em novas teorias científicas sem supor sua tradução ("comensuração") com outras teorias já conhecidas. 
mações internas a cada programa, perde a conotação de uma comparação de cunho popperiano centrada na refutabilidade de programas submetidos a testes críticos comuns. O que fica, então, da tradição racionalista a que se diz pertencer, é a avaliação da mudança científica segundo padrões de racionalidade, cuja eficácia será criticada por Feyerabend (1977, cap. XVI), examinando a ambigüidade da posição de Lakatos - enquanto é racionalista, segundo seus próprios padrões, é um anarquismo disfarçado; enquanto não é racionalista, diverge do anarquismo e, por fim, avaliando sua possível contribuiçăo a uma posição anarquista.

Feyerabend concorda com a versão mais liberal do racionalismo apresentada por Lakatos, com sua crítica ao falseacionismo popperiano, com sua percepção da distância existente entre as "imagens" da ciência e a "coisa mesma", com sua sugestão para que seja concedido um "espaço livre" ao desenvolvimento das novas teorias antes de julgá-las e, em especial, com o papel crítico atribuído à história da ciência quanto à avaliação dos padrões metodológicos. Todavia, discorda de Lakatos, como já foi antes apontado, por este privilegiar, e do modo como o faz, a ciência moderna como base para os padrões de avaliação do desenvolvimento de programas e do comportamento dos cientistas em sua adesão ou rejeição aos mesmos. Sobretudo, discorda da sua face conservadora.

Posto que seus padrões não determinam ao cientista como proceder, auxiliando-o, apenas, na avaliação da situação histórica em que toma decisões, podendo ser racional ou não apegar-se dogmaticamente a um programa estagnado (havendo razões objetivas para tanto), diz Feyerabend que "qualquer opção do cientista será racional, porque é compatível com os padrões" (Feyerabend, 1977:290). Nesta medida, enquanto racional, conforme a seus próprios padrões de racionalidade, a posição de Lakatos é um anarquismo disfarçado. Contudo, recebe a força das pressões das instituições divulgadoras e financiadoras da pesquisa e busca suporte noutras teorias da racionalidade, cujos padrões conduzem a um conservadorismo, como é o caso dos padrões da racionalidade do senso comum, a que Lakatos apela, sem esclarecer que é inteiramente diversa da racionalidade dos padrões mais liberais da metodologia dos programas de pesquisa. Deste modo, a partir de um ponto de vista prático, seu racionalismo dá lugar ao estabelecimento de padrões conservadores, fixos e regulares. Feyerabend diz que Lakatos quer que o todo da vida intelectual se conforme a certos padrões fixos, na medida em que quer fazê-la "racional", quer fazer crescer a história interna ${ }^{32}$ (normatizada), e tem nestas pressões de ordem

32 Embora seja discutível que a racionalidade da história interna de Lakatos traduza-se no estabelecimento de padrões que fixem o dinamismo que, de outro modo, desponta como âmago de sua nova teoria da racionalidade e da metodologia na qual esta racionalidade se concretiza, sua apresentação em termos de uma nova teoria e de padrões metodológicos expressa a pretensão de que as "decisões ocorram com certa regularidade", tarefa que fica reservada àquelas coerções de ordem prática (Feyerabend, 1977:p. 301). 
prática os meios para fazê-lo: "Chegamos, portanto, ao legal e ordenado sem reduzir o liberalismo de nossa metodologia" (Feyerabend, 1977:301), sem que os meios que o operacionalizam tornem-se irracionais, uma vez que aquelas decisões conservadoras não conflitam com as regras! Nesta medida, o racionalismo de Lakatos afasta-se daquela sua intrínseca racionalidade liberal, cujos padrões nada dizem sobre a racionalidade ou irracionalidade da atitude liberal ou da conservadora, e diverge do anarquismo.

Porém, Feyerabend conclui que, pelo modo como Lakatos apresenta sua metodologia, esta revela, em relação à teoria tradicional do conhecimento, um aperfeiçoamento sensível - seus padrões estão mais próximos da ciência e podem ser revistos com base na história das ciências (1977, cap.XVI). Um exame mais "racional", mais fundamentado, revelaria algo diverso e, curiosamente, "irracional" no procedimento de Lakatos: não mostrou que seus padrões são os da ciência, não refutou o anarquismo, nem estabeleceu que sua metodologia corresponde ao melhor programa de pesquisa historiográfica. Entretanto, como é aquela primeira impressão a que influencia o leitor, representando um avanço considerável em relação às teorias anteriores,

podemos dar-lhe apoio sem renunciar ao anarquismo. Cabe mesmo admitir que, no presente estágio de consciência filosófica, uma teoria irracional, falsamente interpretada como versão nova da Razão, será instrumento melhor para a libertação do espírito do que um anarquismo irrestrito, suscetivel de paralisar quase todos os cérebros (Feyerabend, 1977:319).

À luz da argumentação desenvolvida, Feyerabend contesta não apenas a pretensão "absolutista" dos preceitos metodológicos do racionalismo, que a história mostra constantemente "violados", como as distinções básicas em que se apóia: termos observacionais/termos teóricos, ciência/história da ciência, contexto de justificação/contexto de descoberta (Feyerabend, 1977:cap. XIV). Ao passo que a primeira se encontra já bastante "desacreditada", as duas últimas ainda são divisores de águas importantes entre modos de analisar a ciência, cujo questionamento recebe um novo enfoque a partir dos estudos de caso realizados por Feyerabend, com minuciosos exames do papel de fatores contextuais e circunstanciais e reconstituição do contexto de descoberta, levando a uma crítica das considerações acerca dos testes que perfazem o contexto de justificação:

na história da ciência, padrōes de justificação proíbem, freqüentes vezes, formas de agir provocadas por condições psicológicas, socioeconômico-políticas e outras de caráter 'externo' - e a ciência tão-somente sobrevive porque se permite que essas formas de agir prevaleçam (Feyerabend, 1977:260). 
Por fim, cabe mencionar que, dentro destes novos questionamentos e nutridas pela detalhada análise que faz da questão da incomensurabilidade, estão as reflexões de Feyerabend sobre as relações entre subjetividade e objetividade, ciência e outras "gerais, coerentes e frutíferas concepções de mundo", ciência e sociedade, repercutindo na sua visão da racionalidade. Quanto ao primeiro ponto, Feyerabend critica o desiderato de objetividade do racionalismo, de algum modo centrado na "tradicional" identificação da objetividade com o que seja racional, abstrato, independente da situação (de opiniões e compulsōes históricas), produzido pelas próprias coisas. Diz Feyerabend (1981:238, nota 17) que nenhum dos autores que defendem standards "objetivos" explicam o que esta palavra significa. Os popperianos, segundo Feyerabend, ocasionalmente conectam objetividade com verdade e chamam de "objetivas" as comparações entre teorias apenas se baseadas numa comparação do conteúdo de verdade. Chamam os standards remanescentes de "subjetivos" e esta é a razão pela qual Feyerabend assim se refere a eles. Afirma (no corpo do texto) que há comparação, mesmo objetiva, mas que esta comparação é um procedimento muito mais complexo e delicado do que os racionalistas supõem. A posição de Feyerabend é a de que "há muitas e complexas interações entre 'sujeito' e 'objeto' e muitas maneiras pelas quais um desemboca no outro" (Feyerabend,1981:2). A seu ver:

É possível conservar o que mereceria o nome de liberdade
de criação artística e usá-la amplamente, não apenas como
trilha de fuga, mas como elemento necessário para desco-
brir e, talvez, alterar os traços do mundo que nos rodeia.
Essa coincidência da parte com o todo (o mundo em que
vive), do puramente subjetivo e arbitrário com o objetivo e
submisso a regras, constitui um dos argumentos mais fortes
em favor da metodologia pluralista (Feyerabend, 1977:71).

Quanto ao segundo ponto, Feyerabend diz: "Há mitos, há dogmas da teologia, há metafísica e há muitas outras maneiras de elaborar uma cosmovisão" (Feyerabend, 1977:279). As similaridades entre estrutura, processo de elaboração e dinâmica da função explicativa do mito e da ciência são surpreendentes (Feyerabend, 1977, cap. XVIII). Segundo sua avaliação, não apenas consideraçōes de ordem especulativa, mas prática, face à repressão a outras maneiras de elaborar cosmovisões que coincide com o surgimento da ciência moderna, ensejam que hoje questionemos as relações entre Estado e ciência - o que nos leva ao terceiro ponto levantado. A ciência possui uma ideologia própria e não deve ter prerrogativas maiores do que as concedidas a outras ideologias num Estado democrático, onde os cidadãos devem poder escolher a forma 
de vida desejada. Feyerabend questiona não o fato de a ciência possuir sua própria ideologia e impô-la a seus adeptos, mas a ausência de oportunidade para uma tal escolha pelos que são a ela submetidos ${ }^{33}$. Em sua educação, deveriam ser expostos a diferentes cosmovisóes, antes que fizessem sua escolha pela ciência, com suas exigências próprias: "Cabe ensiná-la, mas tão-somente àqueles que decidiram aderir a essa particular superstição" (Feyerabend,1977:464).

A análise da ciência empreendida por Feyerabend permite, por sua vez, esclarecer a razão do tratamento especial que ela recebe (Feyerabend, 1977, cap. XVIII). Deve-se ao "conto de fadas" de que a ciência não é mera ideologia, mas medida objetiva de todas as ideologias. A desmistificação deste conto revela o caráter democrático da ciência na sua dinâmica interna ${ }^{34}$, apesar de seu ocultamento na sua apresentação ao público maior, alegando, então, os cientistas que só os fatos, a lógica, a metodologia decidem. O desvelamento da ciência, expondo-a em seus mecanismos irracionais, à luz das regras do racionalismo, acaba sendo o meio pelo qual qualquer decisão pela ciência seja muito mais racional, calcada na visão esclarecida e sopesada de razões, do que tem sido. E, conclui Feyerabend seu Contra o Método, dizendo: "a racionalidade de nossas crenças se verá consideravelmente acentuada" (Feyerabend, 1977:466). O que nos leva a indagar se, à base das reflexões que animam a análise da ciência feita por Feyerabend, não se encontra o questionamento das relações entre razão e anti-razão, deixando aberta a porta para pensá-las em termos de uma nova racionalidade.

Sumarizando: assim como o exame da questão da racionalidade em Lakatos emerge de seu enfoque de uma racionalidade científica, a crítica de Feyerabend ao racionalismo encontra locus privilegiado em sua análise do desenvolvimento da ciência na cultura ocidental, remontando a uma peculiar tradição de concepção do conhecimento, calcado na admissão de "umas poucas idéias abstratas e independentes da situação", por meio das quais são geradas "estórias" ("provas", "argumentos"), cuja trama "segue da" natureza das coisas mesmas, exibindo, assim, objetividade e dando lugar a apenas uma estória aceitável" (a verdade). Esta tradição corporificou-se em padrões metodológicos que encontram sua expressão contemporânea mais lapidada no racionalismo crítico de Popper e sua abertura mais liberal na racionalidade da metodologia dos progra-

33 "A sociedade moderna é 'copernicana', mas não porque a doutrina de Copérnico haja sido posta em causa (...); é 'copernicana' porque os cientistas são copernicanos e porque lhes aceitamos a cosmologia tão acriticamente quanto, no passado, se aceitou a cosmologia de bispos e cardeais" (Feyerabend, 1977: 456).

34 "No fundo, pouquíssima diferença há entre o processo que leva ao anúncio de uma nova lei científica e o processo de promulgação de uma nova lei jurídica: informa-se todos os cidadãos ou os imediatamente envolvidos, faz-se a coleta de 'fatos' e preconceitos, discute-se o assunto e, finalmente, vota-se (Feyerabend, 1977: 457). 
mas de pesquisa de Lakatos. A ambos, embora não pelas mesmas razões, Feyerabend dirige, em especial, sua crítica, onde aflora um dos traços mais significativos de sua análise: a discussão da incomensurabilidade das teorias compreensivas. $\mathrm{O}$ alvo fundamental de sua crítica é o caráter estático da racionalidade em que se baseia tal tradição. Ao invés desta base e de seu enfoque em termos estritamente metodológicos, Feyerabend situa sua análise da ciência e, a fortiori, da racionalidade, numa rede de pressupostos epistemológicos, ontológicos, humanistas e pedagógicos, colocando-a na perspectiva mais ampla da questão do conhecimento, das relações sujeito/objeto, ciência/não-ciência - de modo que a discussão da racionalidade da ciência passa a integrar a da racionalidade maior da vida do homem e de suas decisões comunitárias, explorando as relações da ciência com outras maneiras de elaborar cosmovisões, e apresentando-a, na educação dos cidadãos e nas relações entre os diversos grupos e instituições, como uma das possíveis formas de vida, sem prerrogativas especiais.

Tendo por objetivo mostrar que não há algo como "o" conjunto de regras que se aplique a todas as situações, Feyerabend identifica sua posição, a favor de uma metodologia pluralista, como anarquismo epistemológico. Em sua defesa, que é também crítica ao racionalismo, adota uma estratégia anarquista - valendo-se de irrepreensível capacidade argumentativa, mostra a irracionalidade do racionalismo e a razoabilidade do irracionalismo, ou seja, das contra-regras que caracterizam a contra-indução, opondo-se aos ideais (empiristas) do racionalismo. De modo similar, expõe sua crítica à forma mais liberal do racionalismo, representada pela teoria de Lakatos, mostrando que, enquanto racional (conforme aos padrões), aproxima-se do anarquismo e que diverge deste quando não é racional. Exemplifica, com sua argumentação, o poder crítico da história das ciências no esclarecimento do próprio processo de desenvolvimento da ciência. Do ponto de vista da práxis científica, a utilização de recursos para os quais não se dispõe de boas razões, faz-se necessária para a própria satisfação dos padrões de justificação racionalistas. Atinge, desta maneira, não só os preceitos metodológicos do racionalismo, como as distinções básicas em que se apóia: termos observacionais/termos teóricos, história da ciência/ciência, contexto de descoberta/contexto de justificação. Sua crítica, porém, não exclui, seja pelo testemunho de sua habilidade argumentativa, seja pelo teor que confere à sua análise, contra uma visão "absolutista" e a favor da concorrência mutuamente esclarecedora de diferentes forças, toda e qualquer racionalidade. É com a abertura a um novo questionamento que encerra sua conhecida exposição na edição de Contra o Método mais difundida entre nós (1977): “E a racionalidade de nossas crenças se verá consideravelmente acentuada".

Tal abertura, sinalizando para a visão de uma racionalidade contextualizada, vem ao encontro de revisões que faz em sua postura, na edição de Against Method de 1993. Ao final da introdução à edição inglesa de 1975 (tradução pela Editora 
Francisco Alves, 1977), diz que poderá vir um tempo em que seja necessário dar à razão uma vantagem temporária sobre a metodologia anárquica, mas que não pensava que estivéssemos vivendo este tempo. Na edição inglesa de 1993, assim escreve:

\begin{abstract}
Esta era minha opinião em 1970, quando escrevi a primeira versão deste ensaio. Os tempos mudaram. Considerando algumas tendências na educação dos Estados Unidos ('politicamente correto', menus acadêmicos etc.) em filosofia, (pós-modernismo) e o mundo em geral, penso que se deva dar à razão, agora, um peso maior, não porque ela seja e sempre tenha sido fundamental, mas porque isso parece ser necessário, dadas as circunstâncias que ocorrem bem freqüentemente hoje (mas que podem desaparecer amanhã), para criar uma abordagem mais humana. (Feyerabend, 1993a:13, n12)
\end{abstract}

Em 1993, Feyerabend discute em maior detalhe a questão da "racionalidade" e diz ser possível avaliar padrões de racionalidade e aperfeiçoá-los. Na edição de 1988 (trad. Relógio D’Água, 1993), o caminho já parece claramente aberto. Dedica seu capítulo 18 ao exame da possibilidade de avaliar modelos de racionalidade e melhorá-los, sem que os princípios de melhoria se encontrem acima da tradição ou para além da mudança, onde esclarece sua posição:

Um anarquista ingênuo diz: a) que tanto as regras absolutas como as regras dependentes do contexto têm seus limites e conclui b) que todas as regras são inúteis e devem ser postas de lado. (...) embora concorde com a), não concordo com b). Sustento que todas as regras têm os seus limites e que não existe uma "racionalidade" englobante. Não sustento que devamos proceder sem regras nem critérios. (Feyerabend, 1993a:314)

De modo geral, é difícil criticar a análise empreendida por Feyerabend, em grande parte devido à ausência de uma teoria da ciência que lhe possa ser imputada, à luz da qual pudessem ser julgados seus alcances e limites, sua propriedade e suas inconsistências. Podemos criticar-lhe o fato de não oferecer esta teoria, entendida como uma grande visão ou um grande esquema aplicável a diversos contextos da ciência, uniformizando sua análise? A que título? Os princípios gerais que encontramos em Feyerabend, como o tudo vale, são suficientemente "vagos", podendo comportar variadas determinações. E não cabe cobrar-lhe esta vagueza, pois não pretende construir uma crítica com base num novo corpo de princípios firmes e imutáveis.Como afirma na sua última e mais amadurecida versão de Against Method, "(...) não penso que prin- 
cípios possam ser usados e frutiferamente discutidos fora da situação concreta de pesquisa que se espera que eles afetem (...)" (Feyerabend, 1993). Podemos, contudo, atentar a alguns aspectos, que talvez amenizem o impacto de sua crítica, ou até permitam vê-la com mais clareza. De início, podemos perguntar-lhe se ela teria o mesmo efeito, caso tomasse como alvo não a razão "monolítica", estática, a que se refere, mas uma razão contextualizada, possibilidade aberta pelo próprio fato da sua crítica. Feyerabend ora insinua, ora dissimula, sem esclarecer, uma possível distinção de alvos, em sua crítica, entre uma racionalidade monolítica, estática e uma racionalidade que comportaria padrões que, na visão tradicional, seriam "irracionais". A resposta a estas questões pode apontar à necessidade de combater aquele que é, propriamente, o adversário, ou seus pertinazes resquícios - o racionalismo naquela sua expressão mais forte. A concessão que, ao final da edição de Against Method (trad. Francisco Alves, 1977), Feyerabend faz ao racionalismo de Lakatos indica esta direção, claramente introduzida já na edição de 1988 (trad. Relógio D’Água, 1993).

No que concerne ao procedimento de análise adotado e ao suporte que pretende encontrar na inteligibilidade provida aos estudos de caso, basta a Feyerabend que sua versão seja "razoável". Teriam as coisas efetivamente ocorrido deste modo? À luz dos pressupostos de análise tomados, esta não é uma questão apropriada; a realidade, a objetividade, a verdade, também são contextualizadas, dependendo daquela interação entre o dado material e o "estilo" dado por nós à sua determinação. Seguindo neste tom, porém, cabe indagar acerca da própria determinação ${ }^{35}$, da história da ciência que serve de crivo para nossas "visões ", demandando uma discussão dos seus pressupostos teóricos: e como fica a questão de se propor ou não uma teoria da ciência? Novamente, o que dificulta uma crítica mais afiada é o fato de que basta, para Feyerabend, trazer elementos, na sua reconstituição histórica, que não se "enquadrem" nos esquemas que estão sendo criticados. Ao não se "enquadrarem", cairão sob o abrigo de sua visão, que acolhe fatores complexos e diversos.

Algumas dificuldades, cuja resolução seria empírica, não demandando, propriamente, questões de princípio, concernem ao como criar um padrão externo de comparação crítica, para desvelamento de pressupostos e exploração da evidência - até onde podemos "decidir" acerca destes referenciais que nos orientam? Até onde podemos "trocá-los"? Até onde pode ir esta "exterioridade" sem comprometer a "compara-

35 A contextualização não é sinônimo de mero arbítrio individual. Em 1993, Feyerabend chama atenção para mal-entendidos simplistas de suas idéias, ressaltando seu interesse em mostrar que "não há soluções gerais" e que não é “(...) nem um populista para quem o apelo 'ao povo' é a base de todo o conhecimento, nem um relativista para quem não há 'verdades enquanto tais', mas apenas verdades para este ou aquele grupo/indivíduo. Tudo o que digo é que os não-especialistas freqüentemente sabem mais que os especialistas e devem, conseqüentemente, ser consultados, e que os profetas da verdade (incluindo aqueles que fazem uso de argumentos), mais frequiente que raramente, são levados por uma visão que colide com os próprios eventos que essa visão deve explorar" (Feyerabend, 1993). 
ção"? A resposta pode ser a mesma que caberia dar à pergunta: como podemos criar um novo sistema? Dado que a criação daquele padrão demanda ou resulta na criação de um novo sistema, o que se coloca como prioritário: a criação de uma "medida" de comparação crítica ou de um "novo sistema"? Estaria o cientista engajado na discussão/elaboração/defesa de sua proposta, preocupado (um tanto popperianamente) com um padrão de crítica para sua teoria? Não parece ser esta a visão de Feyerabend. De qualquer modo, uma defasagem entre a preocupação determinante do comportamento do cientista (preocupado com a elaboração de um "novo sistema") e seu posterior exame (arrogando a necessidade de um padrão externo de crítica para exploração da evidência e comparação de teorias) não compromete sua análise. E, em ambos momentos ou enfoques, teriam lugar procedimentos "irracionais", conforme apregoa.

Prosseguindo, tangenciamos uma questão de princípios: como conciliar a criação de um padrão externo de comparação crítica ou de um novo sistema e a questão da incomensurabilidade? Talvez o processo comece com uma "comparação" e, em seu desvelamento, revele uma "incomensurabilidade". A respeito desta, uma das questões que mais rapidamente vêm à mente é: como falar da própria incomensurabilidade de duas teorias, caso ela exista, sem comensurá-las? A este primeiro ataque, cabe lembrar as ressalvas de Feyerabend e ter em mente que não podemos dizer que diferentes teorias sejam, por esta única razão, incomensuráveis, e que o sejam sob qualquer aspecto. Devem ser teorias compreensivas, estabelecendo princípios ontológicos conflitantes, e ser interpretadas de uma determinada maneira, realisticamente, atentando à constituição ontológica. Mesmo assim, ainda podem ser comparadas, com os alcances e limites de uma tradução lingüística ${ }^{36}$, como a de um idioma nativo numa língua européia: "O que não quer dizer que essa língua, tal como falada, independentemente da comparação, seja comensurável com o idioma nativo. Significará que as línguas podem orientar-se em muitas direções e que a compreensão independe de qualquer particular conjunto de regras" (Feyerabend, 1977:376). Assim, podemos nos situar num patamar "fora" das teorias envolvidas e, procedida a investigação semântica nos termos do método antropológico preconizado, examinarmos sua comensurabilidade/incomensurabilidade. Esta é uma questão que se coloca quando nosso objeto é a análise de teorias constituídas.

Muitas das objeçóes lançadas à tese da incomensurabilidade têm em vista questões mais específicas. Dentre estas, estão as de que tornaria as teorias empiricamente irrefutáveis e impediria uma decisão entre elas. Em resposta, Feyerabend lembra que,

36 Feyerabend (1979) e Kuhn (1979) examinam detidamente a questão da incomensurabilidade em termos de "tradução de linguagens". 
embora caiba exigir de uma teoria apenas o que ela promete explicar, as previsões que estabelece comumente dependem de seus enunciados e também das condições iniciais, podendo ser contradita pela experiência. Certamente nos decidimos entre teorias - dentro de um mesmo ponto-de-vista cosmológico, são possíveis juízos de verossimilitude; no caso de diferentes pontos-de-vista cosmológicos abrangentes, cabe considerar contradições internas às teorias estabelecidas, juízos estéticos, de gosto, preconceitos metafísicos, aspirações religiosas; "em suma, o que resta são nossos desejos subjetivos", a ciência devolvendo ao indivíduo uma liberdade que ele parece perder quando em suas partes mais vulgares (Feyerabend, 1977:412).

\section{4. "ADEUS À RAZÃO" OU "PRINCÍPIOS DE RACIONALIDADE RADICALMENTE DIFERENTES"?}

Buscando dar, em poucas palavras, a chave para as posições de Feyerabend e de Lakatos, é tentador fazê-lo com expressões cunhadas por estes próprios autores, em termos de "adeus à razão" (Feyerabend, 1987) e de "princípios de racionalidade radicalmente diferentes" (Lakatos, 1979). Coloca-se, então, a questão: estas expressões conflitam? Que "razão" é esta, a ser abandonada? Que "racionalidade" é esta, com princípios radicalmente diferentes? Diferentes da "razão" que Feyerabend propõe abandonar? E esta "razão" é aquela dos princípios de "racionalidade" a serem, também, abandonados, deixados por outros "radicalmente" diferentes? Se for assim, penetrando na fachada semântica destas expressões, poderemos nos deparar com uma série de convergências, além daquelas concordâncias de que falou Feyerabend, talvez obscurecidas pela ambigüidade com que nossos autores tratam alguns de seus pontos centrais, indicativa, de resto, de períodos de transição na busca de novas abordagens.

Um dos pontos de convergência encontra-se na idéia, já referida no início, de uma racionalidade contextualizada. Em que pese sua crítica contundente ao racionalismo, Feyerabend nos faz suspeitar, inicialmente, que esta tradição, com sua teoria estática da racionalidade, não conta toda a estória relevante a respeito desta racionalidade. Esta suspeita claramente se confirma nas edições posteriores de Against Method. Sua análise revelou que o racionalismo demanda, a serem satisfeitas suas exigências, procedimentos irracionais. De outro lado, na defesa do irracionalismo, Feyerabend empenha-se em mostrar sua razoabilidade. Onde estão as fronteiras entre "racional" e "irracional"? Trazendo para seu anarquismo epistemológico as palavras de Hans Richter sobre o dadaísmo, cita Feyerabend: "A compreensão que razão e anti-razão, sentido e sem sentido, intenção e acaso, consciência e nãoconsciência [e, acrescentaria eu, humanitarismo e anti-humanitarismo] são, em conjunto, partes necessárias de um todo (...)" (Feyerabend, 1977:294). Que razão seria 
esta, parceira de sentido, intenção, consciência, humanitarismo e de anti-razão e seus associados? Não deve ser aquela da tradição de uma "estória única" - e se o fosse, seria essencialmente modificada por suas novas relações.

A racionalidade que Feyerabend nos deixa entrever seria uma racionalidade certamente contextualizada - capaz de dar conta da diversidade exigida pelas diferentes e complexas "situações", sem privilegiar um conjunto particular de regras (o que não é o mesmo que mera exclusão de regras). $E$, como tal, é uma racionalidade que faz crescer nossa humanidade, nossas aptidões e nossa consciência, vindo ao encontro daquela idéia motora da concepção de conhecimento oferecida por Feyerabend, que antes vimos. De início, sua discussão fica circunscrita a uma visão tradicional de racionalidade, esgueirando-se a possibilidade de uma nova racionalidade por entre insinuações e dissimulações. Esta possibilidade é tematizada nas edições de 1988 e 1993. O teor da crítica muda, se circunscrevemos a racionalidade à contextualidade histórica, condição apregoada por este autor para a compreensão da natureza da ciência. Lakatos, por sua vez, claramente advoga, para a salvação de uma posição racionalista, uma nova visão de racionalidade, precedida por uma crítica explícita a seu enfoque clássico. Está, pois, em jogo, uma crítica e uma defesa do racionalismo que desmobiliza a questão de um enfoque monolítico e admite diferentes teorias da racionalidade, permitindo-nos supor a visão de uma racionalidade contextualizada como objeto de exame.

Ambas as análises, portanto, criticam uma concepção tradicional de racionalidade e, pela função que conferem à história da ciência, focalizam uma racionalidade "concretizada", contextualizada em sua determinações. Esta constatação, porém, não nos autoriza a falar numa racionalidade fragmentada. Trata-se, antes, de uma racionalidade mais dinâmica, a ser estabelecida sobre novos princípios, e não sobre pedaços da racionalidade clássica de algum modo reunidos. Este dinamismo pode ser compreendido, à luz da dialética a que Feyerabend se refere em diversas passagens, bem como da apresentação que Lakatos faz de sua nova racionalidade (divergindo tanto de uma redução a padrões imutáveis, quanto a situaçōes particulares), como uma tensão dialética entre o "todo" e a "parte", com uma racionalidade capaz de reconhecer-se através dos diversos contextos em que se concretiza. Esta convergência inicial, na direção de uma racionalidade contextualizada, não assegura, contudo, que ambos compartilhem os mesmos princípios de (re)construção da racionalidade atingida na crítica à tradição. Lakatos parece já ter os seus estabelecidos, ao passo que Feyerabend apenas nos deixa a questão em aberto. Todavia, serão os princípios de Lakatos suficientemente claros para cumprir tal função e estarão tão distantes do caminho que Feyerabend insinua? Vejamos estas questões analisando alguns pontos que suas análises revelam centrais ao exame da racionalidade. 
Os princípios de Lakatos, expressos em seus padrões metodológicos, devem, segundo sua própria exigência, se mostrar efetivos na história da ciência. Esta história é, a seu ver, a história interna, construída segundo as normas lógicas e epistemológicas daquela razão que Feyerabend talvez chamasse "abstrata" (das "idéias abstratas", "provas", "argumentos"). Todavia, ao ser construída, o é com o material (a história) que o próprio Lakatos admite não ser plenamente redutível ao que estamos agora chamando de "abstrações". Esta condição faz com que não só a história receba a orientação filosófica, mas dê-lhe força, conteúdos (razões caras a Lakatos!). Protege, igualmente, a proposta de Lakatos de um "falseamento", explicando, devido àquela irredutibilidade, a presença de "anomalias". Há, pois, uma mútua contribuição do material histórico e da reflexão filosófica (como também prega Feyerabend), fazendo da racionalidade lakatiana uma racionalidade concretizada, uma universalidade que se particulariza e assim exerce sua função explicativa. Não estariam, pois, os fatores "situacionais" penetrando na racionalidade lakatiana? Se isto ocorresse, estaríamos na direção de uma racionalidade possível (e desejável) na perspectiva de Feyerabend.

De modo mais incisivo, porém, esta possibilidade coloca-se quando revelamse escorregadias as distinções que Lakatos estabelece entre esfera objetiva, da história interna, do elenco de razóes a dar conta do crescimento e da mudança científica, e esfera subjetiva, da história externa, do contingente irracional. Em sua própria análise, encontra-se, não consentida, a abertura a uma interpenetração destas esferas para a própria consecução da racionalidade pretendida. A flexibilidade de seus padrões traz, em seu interior, a possibilidade de um novo elenco de razões, que daria vazão à racionalidade exibida na condição de uma racionalidade historicamente construída, fundada numa imaginação criativa, irredutível a uma aplicação mecânica de regras e suscetível, nas decisões "práticas" que a corporificam, a fatores que Lakatos, no seu lado mais "tradicional", insiste em excluir daquele elenco. Em sua maior "novidade", Lakatos considera "muito difícil derrotar um programa de pesquisa sustentado por cientistas talentosos e imaginativos" (Lakatos, 1979:195).

Há razões objetivas que legitimam o obstinado empenho em buscar novas evidências corroboradoras que recuperem um programa em degeneração. Como, então, dar conta do modelo ou do programa historicamente realizado - "o modelo realmente realizado depende apenas do acidente histórico" (Lakatos, 1987a:186), da racionalidade da decisão de que já foi dado (ou não) tempo suficiente para a recuperação de um programa em degeneração, sem a determinaço de "outras" razões ${ }^{37}$, a serem buscadas no âmbito que Lakatos atribui à história externa,

37 Explorando, talvez, aquela discreta abertura de Lakatos ao se referir, numa única passagem, em Lakatos (1979:172), a uma "razão racional". Haveria outra? 
ao irracional? Por que não trazer, ao campo das decisões que perfazem o "programa reconstruído", as "obstinações" que o moveram, buscando a história dita externa não apenas como complementação, mas como encerrando condições igualmente determinantes da racionalidade científica? A "racionalidade" advogada por Lakatos abre-se a uma nova conceituação, esperando-se, assim, a abertura a novos critérios para o que sejam as "razões" a pautar o desenvolvimento da ciência. Lakatos, porém, não persegue a nova trilha e, assim procedendo, expõe-se à crítica de Feyerabend: "Com efeito, é muito possivel que uma ciência tenha uma determinada história 'interna' apenas porque sua história 'externa' encerra atos compensadores que, a cada instante, violam a metodologia que a define" (Feyerabend, 1977:316).

Fundamentalmente, a discussão que permeia a questão da racionalidade, com ressonâncias para todas as demais, hoje coloca sobre a mesa a questão do que sejam razões e boas razões. Enquanto faculdade, o reconhecimento da nova abertura requerida para razão vem de há muito se preparando e hoje solidamente se apresenta, ao ser atribuída a função metodológica ou mesmo metametodológica à imaginação criativa, caixa de agradáveis surpresas (embora tenha havido tempo em que foi responsável pelos "desastres" ou "ilusões" da razão). O ponto, então, a ser enfrentado é o do estabelecimento do que sejam razões, aqueles elementos produzidos ou arrolados para sustentar as nossas alegações, conferindo a estas legitimidade. A este respeito, Feyerabend vai mais longe que Lakatos, senão na resposta, na colocação do desafio e disponibilidade para enfrentá-lo. O desvelamento da ciência, expondo-a em seus mecanismos irracionais, à luz das regras do racionalismo, acaba sendo não só o meio pelo qual qualquer decisão pela ciência seja muito mais racional, como aquele pelo qual transparece o nível próprio de adesão que a constitui internamente, as razões próprias que movem as decisões dos que a fazem, seu rationale próprio. Lakatos permanece, aqui, preso a uma velha e desconfortável roupagem, constrangendo sua nova racionalidade. E aqui impõem-se a pergunta pela distinção subjetivo/objetivo. O que nos levaria a buscar as razões, no âmbito da história interna, tal como distinguida por Lakatos, atribuindo à história externa, ao plano subjetivo, o irracional? Teria algo a ver com o fato de o segundo dizer respeito a motivações do sujeito humano, demasiado complexas e dinâmicas? Ou com a rotulação destas motivações como sendo arbitrárias, sujeitas a um arbítrio que escaparia a um juízo universal, ao passo que aquelas razões lógicas e empíricas proveriam juízos suficientemente universais e estáveis, com uma validade de algum modo independente de "manipulações" servindo a interesses particulares, que não o de "busca da verdade"? Será, de outro lado, a preocupação com a "verdade" conflitante com os interesses de natureza sociopsicológica e, mais ainda, será a sua busca distintiva do (e, assim, exclusiva ao) conhecimento científico, ou restrita aos padróes da racionali- 
dade de Lakatos? Poderá, em qualquer caso, ser determinada ou "encontrada" sem o elenco de significações, envolvendo estas crenças e valores, que os indivíduos e comunidades que a buscam emprestam ao que é empiricamente dado?

$\mathrm{Na}$ esteira de tais indagações, a pergunta pela racionalidade a que fomos conduzidos pelo braço epistemológico da história da ciência, faz-nos avançar e remete ao tripé histórica e filosoficamente estabelecido do racionalismo - racionalidade, objetividade e verdade -, de modo que o questionamento de um envolve a todos. Junto à discussão do que sejam "boas razões", entra em pauta a questão da verdade, na forma da questão de um "critério de comensuração", de uma "estória comum", da "única a ser contada". E nos damos conta de que, a partir do ponto de vista filosófico, não há como isolar por muito tempo os fios daquela malha. Não há como discutir a racionalidade, sem discutir as "boas razões", a "relação sujeito/objeto" e a questão da "comensurabilidade/incomensurabilidade" - de modo especial, sem discutir as boas razões, pois já é lugar comum que, no que se refere à verdade, dependemos da rede de significações e de sua discussão, trazendo à pauta o que sejam "boas razões". As questões estão postas, caminhos estão indicados, falta-nos encontrar as respostas. 


\title{
Os Intelectuais no Mundo e o Mundo dos Intelectuais: uma leitura comparada de Pierre Bourdieu e Karl Mannheim
}

\author{
Luiz Otávio Ferreira \\ Nara Britto
}

U

ma leitura atenta de alguns dos principais textos teórico-metodológicos de Pierre Bourdieu, que representam um esforço de construção de uma sociologia dos fatos culturais despertou nossa atenção para uma omissão significativa: a ausência de referências a Karl Mannheim (1894-1947).

Esta não é uma omissão irrelevante, uma vez que Mannheim é reconhecido como o fundador da sociologia do conhecimento, disciplina para a qual Bourdieu pretende contribuir.

A partir desta constatação, surgiu uma questão: seria possível estabelecer afinidades ou correlações entre o pensamento de ambos a respeito da natureza social do conhecimento?

Este trabalho não se traduziu numa comparação sistemática das obras destes autores. Não ambicionamos realizar uma sociologia da sociologia do conhecimento, mas, sim, evidenciar o que nos pareceu constituir um conjunto de questões compartilhadas por ambos, a saber: 19 ) a cientificidade da sociologia do conhecimento; 2 ) a crítica da razão a-histórica; 3 -) a autonomia como característica do intelectual no mundo moderno; 49) a educação escolar como forma de diferenciação cultural dos intelectuais; $5^{\circ}$ ) a constituição de campos de conhecimento esotérico.

Não obstante o desenvolvimento diferenciado dos autores em relação a estas questões, pensamos que, reunidas, elas constituem uma espécie de programa para o estabelecimento de uma sociologia do conhecimento, e em particular, da ciência.

Em face das desigualdades de tratamento destas questões pelos autores, tanto do ponto de vista extensivo, quanto nas formulações, muitas vezes, apenas implícitas e pouco desenvolvidas, optamos por uma apresentação em separado de suas abordagens em relação às questões que selecionamos. 


\section{1. É POSSÍVEL UMA SOCIOLOGIA DO CONHECIMENTO?}

O ponto de partida para a compreensão do pensamento sociológico de Mannheim e Bourdieu está na resposta positiva que deram a esta indagação. Isto significou para ambos o enfrentamento do mesmo problema básico: demonstrar que toda forma de pensamento é socialmente condicionada.

Através de desenvolvimentos conceituais e metodológicos singulares, os autores se esforçaram para comprovar esta premissa na qual está fundada a sociologia do conhecimento.

O fundador da sociologia do conhecimento tem sido criticado por sociólogos partidários de diferentes perspectivas teóricas ${ }^{1}$. Um dos pioneiros nessas investidas contra a sociologia do conhecimento mannheimiana foi Robert Merton. Esse autor, reconhecido como o fundador da sociologia da ciência, aponta inúmeras contradições de natureza teórica e deficiências metodológicas no pensamento sociológico de Mannheim. De início, Merton critica o ecletismo teórico fruto das apropriações feitas por Mannheim de pressupostos do marxismo (Marx, Engels e Lukács), do neokantismo (Dilthey, Rickert, Troeltsch e Weber) e da fenomenologia (Husserl, Jaspers, Heidegger e Scheler). Isso, segundo Merton, seria a causa da "instabilidade fundamental na urdidura dos seus conceitos" (Merton,1970:589).

Outro sério problema apontado por Merton é o da indefinição sobre o que está coberto pelo termo "conhecimento", que demarca o universo de investigação da disciplina. "O conhecimento é considerado às vezes de maneira tão ampla que abarca todos os tipos de enunciados e todos os modos de pensamento, desde os provérbios folclóricos até a rigorosa ciência positiva" (Merton, 1970:597). Assim definida a extensão semântica da palavra "conhecimento", seria correto dizer que Mannheim supunha que todas as formas de conhecimento, inclusive o produzido pelas ciências naturais e exatas, são "determinados existencialmente", ou seja, estão determinados pelas condições histórico-sociais em que são produzidos. No entanto, observa Merton, as investigações empíricas deixam entrever que, para Mannheim, somente as "ciências da cultura" teriam seus conteúdos afetados pela situação social e histórica. As ciências da natureza, ao contrário, seriam imunes ao condicionamento social e histórico e, portanto, o processo de produção de conhecimento nessas áreas do conhecimento não poderia ser sociologicamente investigado.

1 A produção intelectual de Mannheim que trata especificamente do tema da sociologia do conhecimento foi escrita entre 1921 e 1931. Depois de sua imigração forçada da Alemanha para a Inglaterra, em 1933, o autor deslocou sua atenção para os problemas do planejamento social. As obras relacionadas à sociologia do conhecimento são: Ideology and Utopia: an introduction to the sociology of knowledge; Essays on the Sociology of Knowledge e Essays on the Sociology of Culture. 
A própria tese central da sociologia do conhecimento mannheimiana a da determinação existencial do conhecimento - é criticada por Merton pelo fato de Mannheim não ter especificado o tipo ou o modo de relações entre estrutura social e conhecimento. Esta seria a "indecisão fundamental de Mannheim" que oscilou entre diferentes tipos de causalidade que pudessem explicar as relações entre pensamento e existência ${ }^{2}$.

O último aspecto da sociologia do conhecimento mannheimiana criticado por Merton é o relativismo. Este é, sem dúvida, o ponto mais controvertido do pensamento de Mannheim. Merton acredita que todo o problema reside no fato de que a sociologia do conhecimento conduz a um relativismo radical quando afirma que todas as formas de pensamento são arbitrárias, não havendo, portanto, nenhum critério de verdade que possa ser universalmente aceito. Segundo Merton, este preceito compromete profundamente a sociologia do conhecimento como disciplina científica.

Embora as críticas de Merton sejam "tecnicamente" corretas, ele não se pronuncia acerca da principal questão teórica enfrentada por Mannheim, a crítica da razão a-histórica.

Como acertadamente observou Susam Hekman - que estudou detalhadamente as bases epistemológicas e metodológicas da sociologia do conhecimento (Hekman,1990) -, o principal objetivo de Mannheim foi elaborar uma crítica global da concepção iluminista de razão tendo como pressuposto básico a idéia do condicionamento histórico do conhecimento. Para tanto, posicionou-se criticamente frente às principais orientações filosóficas e sociológicas de seu tempo - positivismo, apriorismo formal, fenomenologia e historicismo - afirmando que todas elas, exceto a última, estavam comprometidas com a concepção iluminista de uma razão a-histórica ${ }^{3}$.

Mannheim deixa evidente sua opinião sobre a natureza histórica do conhecimento na análise que empreendeu do historicismo e da controvérsia deste com o iluminismo, cuja principal questão residia no debate acerca do caráter estático ou dinâmico da razăo.

2 Segundo Merton, as formas de causação apresentadas por Mannheim são: 1) supõe uma causação direta de estilo de pensamento e forças sociais, considera que as idéias e formas de pensamento são simplesmente expressão de interesses econômicos, políticos ou religiosos; 2) certas estruturas sociais são requisitos prévios para certas formas de pensamento; 3) supõe que certas formas de pensamento são invariáveis, sendo possível apenas estabelecer seu grau da compatibilidade com determinado contexto histórico (Merton, 1970:597-98-99).

3 Hekman chama atenção para o fato de que "Mannheim não rejeita as perspectivas quer do positivismo quer da fenomenologia, o que o levou a ser classificado por certos comentadores como fenomenólogo, e por outros, como positivista". Mas, apesar disso, Mannheim mantém sua objeção básica a cada uma dessas perspectivas reconhecendo nelas o compromisso com a concepção iluminista de uma razão ahistórica. (Hekman, 1990:94) 
Em seu entendimento, não bastasse ser errônea a concepção científiconatural da razão, ainda deveria se ter em consideração o fato de que o tipo de conhecimento oferecido pelas ciências da natureza é apenas um caso especial de conhecimento, e não um modelo absoluto. Com base nessa crítica, Mannheim reinvindica a legitimidade e validade do conhecimento histórico-social.

Em nossa opinião, o fato de Mannheim não assumir explicitamente o princípio da condicionalidade social do conhecimento científico em geral o levou a estabelecer uma distinçăo radical entre as ciências histórico-sociais e as da natureza, a fim de legitimar a sua própria perspectiva, que denominou relacional.

Utilizando o conceito de conhecimento relacional, Mannheim procurou enfrentar a questão da validade do conhecimento histórico-social, cuja peculiaridade atribuía ao fato de que
há determinadas esferas de pensamento nas quais é im- possível conceber a verdade absoluta existindo inde- pendentemente dos valores do sujeito e do contexto so- cial. Nem mesmo um deus poderia formular uma propo- sição sobre questões históricas semelhantes a $2 \times 2=4$, pois o que é intelegivel na história somente pode ser for- mulado com referência a problemas e construçōes con- ceituais que emergem no fluxo da experiência histórica. (Mannheim, 1976:105)

Para Mannheim, um ponto de vista e um conjunto de conceitos revelam melhor seu significado por se acharem ligados e emergirem de uma determinada situação social. Afinal, o pensamento humano surge e opera não em um vácuo social, mas sim em um meio social definido, não devendo "se encarar como fonte de erro o fato de todo o pensamento se achar enraizado desta forma", e de submetê-lo "à posição do observador" (Mannheim, 1976:105-6).

Segundo Hekman, o relacionismo professado por Mannheim não implica na ausência de critérios sobre verdade e falsidade do conhecimento; supõe, no entanto, que é próprio da natureza do conhecimento histórico ser formulado apenas em relação a uma situação particular, e não de forma absoluta (Hekman, 1990:97).

Assim, para Mannheim, a tarefa da "teoria moderna do conhecimento que considere o seu caráter relacional" é "mostrar como certos suportes intelectuais acham-se vinculados a certas formas de experiência, delineando a íntima interação entre as duas no curso da mudança intelectual e social" (Mannheim, 1976:107).

Segundo Mannheim, o problema de uma sociologia do conhecimento surgiu na cultura moderna como resultado da interação de quatro fatores: 1) a auto-relativizaçáo do pensamento e do conhecimento; 2) o aparecimento de uma nova forma de relativização introduzida pela mudança de mentalidade 
"desmascaradora"; 3) a emergência de um novo sistema de referência, o da esfera do social, a respeito do qual o pensamento poderia ser concebido como relativo; 4) a aspiração de tornar essa relativização total, relacionando não um pensamento ou idéia, mas todo um sistema de idéias a uma realidade social subjacente (Mannheim, 1967:25-6).

Essas são as condições de possibilidade de produção de um conhecimento sociológico que visa examinar "como as várias posições intelectuais e estilos de pensamento estão enraizados numa realidade histórico-social subjacente" (Mannheim, 1967:70).

A sociologia do conhecimento é definida pelo autor como um ramo disciplinar da sociologia, dividindo-a em duas partes: 1) como teoria, sua tarefa é a de analisar a relação entre conhecimento e existência; 2) como método de pesquisa, o seu objetivo é descrever as formas que este relacionamento assumiu no desenvolvimento intelectual da humanidade. Em decorrência, elenca as principais tarefas teóricas e de pesquisa da sociologia do conhecimento:

1. definir critérios para a descoberta da relação entre pensamento e ação;

2. desenvolver uma teoria da significação dos fatores não teóricos que condicionam o conhecimento;

3. especificar os vários pontos de vista intelectuais nos quais o pensamento se baseia e que são possíveis em vários períodos;

4. pôr a descoberto as premissas metafísicas ocultas;

5. encontrar os estratos sociais que compõem o estrato intelectual em questão (Hekamn, 1990:101).

Embora reconheça os méritos da perspectiva apresentada por Mannheim, Susan Hekman ${ }^{4}$ a considera ambígua justamente no ponto crucial para um projeto de análise sociológica da ciência. Ora, ele afirma "que todo o conhecimento é dinâmico, isto é, condicionado historicamente, mesmo o chamado conhecimento objetivo das ciências naturais, ora sugere uma cisão entre o conhecimento

4 A indecisão de Mannheim tem sido constantemente criticada pelo representantes da nova sociologia "construtivista" da ciência. Ver: Mulkay, M. (1979) e Knorr-Cetina, K. \& Mulkay, M. (1983). Augustine Brannigan, por exemplo, diz que "Mannheim fez questão de deixar a matemática e as ciências naturais fora do escopo da sociologia do conhecimento, possivelmente porque as doutrinas dessas áreas, sendo objetivas, não necessitam de explicações. Só a ideologia e a crença irracional é que precisavam" (Brannigan,1984:113). Na verdade, o que faz a recente sociologia "construtivista" da ciência é simplesmente aplicar o conceito mannheimiano de conhecimento relacional às chamadas ciências da natureza. 
na esfera histórica e o das ciências naturais, da lógica e da matemática, este último definido como absoluto e imutável" (Hekman, 1990:95).

De fato, Mannheim não consegue superar o impasse advindo da distinção radical que estabelece entre a esfera das ciências naturais e a das ciências histórico-sociais. Em vez de negar a idéia de uma razão a-histórica, deveria ter percebido que esta não é uma idéia errada, mas fruto de determinadas condições históricas, as quais devem ser explicadas pela sociologia do conhecimento.

Apesar dos problemas que apresenta, a proposta teórico-metodológica de Mannheim não fica invalidada. As críticas que the foram endereçadas não compreenderam os termos eminentemente histórico-sociológicos de seu argumento, distintos, portanto, de uma ordem formalmente epistemológica.

A principal característica do programa de Mannheim para a sociologia do conhecimento está na radical rejeição da epistemologia. Para ele a verdadeira análise do conhecimento não é aquela que se dedica exclusivamente a desvendar o encadeamento lógico dos conceitos abstraídos de qualquer tipo de condicionalidade. Ao contrário, a tarefa da sociologia do conhecimento é evidenciar o condicionamento social a que está submetida de modo irredutível toda forma de pensamento.

Podemos a esta altura estabelecer uma aproximação com as concepções de Pierre Bourdieu. Para enfrentar o problema do condicionamento social do conhecimento, Bourdieu também desenvolveu uma crítica à epistemologia clássica, aderindo às idéias de Gaston Bachelard a respeito da historicidade da racionalidade científica na reflexão que elaborou sobre o ofício do sociólogo ${ }^{5}$.

Censura à perspectiva de análise que elege relações atemporais entre enunciados abstratos, em detrimento de processos pelos quais cada conceito foi estabelecido e engendrou outras proposições e conceitos. Isto é o mesmo que "deslocar o desenvolvimento das intrigas de bastidores para levar à cena somente os desenlaces" (Bourdieu, 1988:21).

O desenvolvimento da ciência não ocorre pela força intrínseca da idéia verdadeira. Perguntar o que é fazer ciência não significa se interrogar sobre a eficácia e o rigor formal das teorias e métodos, mas acerca das práticas científicas. O que fazem os cientistas com as teorias e os métodos herdados? A tarefa consiste em examinar a sua aplicação para determinar o que fazem com os objetos $\mathrm{e}$ que objetos fazem (Bourdieu, 1988:25).

5 Bourdieu explicitou os vínculos intelectuais com a epistemologia de Gaston Bachelard quando escreveu sobre o ofício do sociólogo, adotando a premissa bachelardiana da positividade do erro. Ou seja, a ciência não se constitui como um todo de verdades positivas, se desenvolvendo pela adição do verdadeiro ao verdadeiro e excluindo o falso. Ao contrário, o processo de conhecimento está baseado na ação polêmica da razão (contra o erro) que atua por retificações incessantes (Bourdieu, 1988). 
Contra o empirismo - que reduz o ato científico a uma comprovação -, e o formalismo - limitado aos preâmbulos da construção do fato científico - Bourdieu invoca Bachelard, e reitera a sua postura epistemológica a respeito do trabalho científico: um fato científico se conquista, constrói, comprova.

Propõe, então, uma análise da ciência "se fazendo", e enfatiza a necessidade de se realizar uma história da ciência que abandone a busca de uma lógica ideal das descobertas a partir de um decálogo de procedimentos, em favor dos processos de produção do conhecimento, eivados de erros e inseguranças. $\mathrm{O}$ objetivo é "descobrir na prática científica as condições nas quais se pode discernir o verdadeiro do falso" (Bourdieu, 1988:20).

Seguindo esta diretriz, a sociologia do conhecimento deve investigar as condições sociais do processo de construção de um fato científico, que não pode ser compreendido em toda a sua extensão se explicado apenas enquanto uma aventura personalizada. É necessário localizar os produtores no campo social de onde extraem as referências de um certo padrão de cientificidade que deve ser seguido.

Segundo Bourdieu, é um equívoco pensar que a objetividade científica possa ter como fundamento a objetividade do investigador, isto é, o seu comportamento e/ou a sua boa vontade. Neste ponto Bourdieu explicita suas diferenças em relação a Mannheim, criticando-o por imaginar que a garantia da objetividade do conhecimento, ocorre por meio de um esforço pessoal de desprendimento de determinações que caracterizam a situação social dos intelectuais. Assim Mannheim pode conceber a ascensão dos intelectuais ao espaço do conhecimento verdadeiro, onde ele situava os seus intelectuais "desenraizados" (Bourdieu, 1988:106).

Para Bourdieu, os cientistas não podem liberar-se das ideologias que incidem em sua investigação pela única virtude de reformar um juízo que está socialmente condicionado, isto é, a objetividade reside nas e pelas relações objetivas do campo científico. É a comunidade científica "com suas instituições de controle, e pressão e formação, autoridades universitárias, jurados, tribunas críticas, comissões, instâncias de cooptação etc. que determinam as normas de competência profissional e tendem a inculcar os valores que expressam" (Bourdieu, 1988:106-7).

Embora compartilhe com Mannheim do mesmo ponto de vista crítico em relação à epistemologia clássica, são visíveis e substantivas as diferenças de enfoque de cada um sobre a questão da objetividade. Sem incorrer no equívoco mannheimiano de estabelecer uma distinção entre o conhecimento natural e sócio-histórico, Bourdieu sustenta por intermédio de um argumento radicalmente sociológico a natureza relacional de todo o conhecimento. Além disso, e em conseqüência desta postura teórica, pretende realizar uma sociologia reflexiva submetendo a prática sociológica à crítica da sociologia do conhecimento. 
Fazendo as vezes de advogado do diabo, Bourdieu questiona a objetividade da sociologia, e se interroga sobre a posição que ela ocupa no campo científico. Aventa a hipótese de que as dificuldades da sociologia da ciência residem no fato de que o sociólogo faz parte do jogo que ele quer descrever, isto é, ele integra o campo científico ocupando uma posição subordinada em relação às ciências naturais.

Deste modo, a possibilidade de se estabelecer uma sociologia do conhecimento ou da ciência está relacionada à construção do campo intelectual como um todo, incluindo a sociologia que se está praticando. Esta é a forma de objetivar o que está em jogo e as estratégias correspondentes, não tomando como "objeto apenas as estratégias de seus adversários cientíicos, mas o jogo enquanto tal, que comanda também suas próprias estratégias, e que ameaça governar subterraneamente sua sociologia, e sua sociologia da sociologia" (Bourdieu, 1983:151-155).

Em sua opinião, esta é a condição para que uma sociologia dos intelectuais "não se limite a uma troca de injúrias, entre intelectuais de direita e intelectuais de esquerda" (Bourdieu, 1983:155).

É imperativo que se faça alusão às mudanças que se processaram no itinerário intelectual do autor quanto a este tema. Neste percurso se afastou da epistemologia de Bachelard, a qual passou a questionar como "processos abstratos e de pouca valia", em favor da abordagem relacional. Por esta via, Bourdieu acabou se assemelhando à perspectiva de Mannheim no que tange ao realce que ambos conferem ao argumento sociológico no debate contra a análise epistemológica do conhecimento (Bourdieu, 1989:17-58). Contudo, mais ousado do que Mannheim, expressa a radicalidade de seu ponto de vista parafraseando o aforismo clássico de Hegel: "O real é relacional" (Bourdieu, 1989:28).

De acordo com Bourdieu, freqüentemente os investigadores incorrem numa atitude "primária" pensando o mundo de forma substancialista e realista; tomam como objeto os problemas relativos a populaçóes arbitrariamente delimitadas e obtidas por divisões sucessivas de uma categoria pré-construída, como por exemplo: os velhos, os jovens, os imigrantes etc. É mais fácil pensar a vida social em termos de realidades palpáveis e visíveis - grupos, indivíduos - do que como um espaço de relações (Bourdieu, 1989:28).

Convicto das vantagens desta abordagem, e das ilusões empiristas sobre o mundo social, Bourdieu considera que é possível cometer equívocos acerca de uma instituição sobre a qual se imagina conhecer tudo, uma vez que ela nada é fora de suas relações com o todo.

No entendimento do autor, não se podem explicar ações sociais nem por meio de uma redução dos agentes ao papel de executantes (à maneira do estruturalismo althusseriano), nem imaginando que elas derivem da vontade dos indivíduos. Para ele, pode-se explicar "a razão e a razão de ser de uma instituição e de seus efeitos sociais no campo de forças antagonistas ou complementares no 
qual - em função dos interesses associados às diferentes posições e dos habitus dos ocupantes - se geram as vontades, e no qual se define e se redefine continuamente na luta a realidade das instituições e dos seus efeitos sociais, previstos e não previstos" (Bourdieu, 1989a:81).

A dificuldade da perspectiva relacional reside no fato de que não é possível pensar nestes termos, senão sob a forma de distribuições de propriedades (características) entre os indivíduos, porque a informação disponível está associada a eles. Para tanto, propõe a construção de tipos ideais passiveis de reunirem as características pertinentes de um conjunto de agentes ou de instituições, que são comparadas e discriminadas nestes termos, segundo suas funções e características.

Por meio de aproximações sucessivas, constroem-se, então, espaços sociais que se oferecem em forma de relações objetivas abstratas, e, as quais, como assinala Bourdieu, "não se pode tocá-las nem com a ponta dos dedos. E esta é toda a realidade do mundo social" (Bourdieu, 1989:29-30).

Estas concepções estão presentes num dos principais instrumentos teóricos a que Bourdieu recorre. Refiro-me, mais especificamente, à noção de campos sociais através da qual analisa a sociedade como espaços autônomos que possuem uma racionalidade regional. A riqueza analítica da noção de campo é justamente a perspectiva relacional que indica, marcando a visão do autor sobre a sociedade.

Como esclarece, a noção de campo se transformou após a aplicação inicial num trabalho sobre o campo intelectual. Neste empreendimento a intenção era opor esta noção às tradicionais formas de interpretação de todos os fatos culturais, submetidos ao formalismo (da análise interna da obra) ou ao reducionismo que impunha às formas artísticas e intelectuais um relacionamento direto e mecânico com formas sociais. Explica que a elaboração mais rigorosa veio a partir da crítica à interpretação interacionista de Max Weber às relações entre os agentes do campo religioso, reduzidas ao plano intersubjetivo ou interpessoal. Em vez disso, trata-se de construir "a estrutura das relações objetivas entre as posições que os agentes ocupam no campo religioso, estrutura que determina a forma que podem tomar suas interações e a representação que delas possam ter" (Bourdieu, 1987a:81-2).

Pretendendo a validade deste postulado para a análise de todos os campos sociais, argumenta que a possibilidade de realização da sociologia da produção intelectual e artística depende da construção do sistema relativamente autônomo de relações de produção e circulação dos bens simbólicos. É assim que ela constitui seu objeto próprio, e, ao mesmo tempo, seus limites.

Em outras palavras, isto significa poder identificar as propriedades de posição (posições estéticas, científicas e políticas, temas, procedimentos, problemas e soluções) no sistema social que uma dada categoria de agentes de produção e difusão cultural deriva do lugar que ocupa na estrutura do campo. Esta posição 
determina a significação e a função das práticas e das obras, e também, a posição que os agentes ocupam no campo cultural mais amplo, definido por Bourdieu como "o sistema das posições culturais objetivamente possíveis em um dado estágio do campo de produção e circulação" (Bourdieu, 1987b:159).

Acresce que a licença para o estabelecimento de uma sociologia do conhecimento é extraída da constatação da autonomização da vida cultural no mundo moderno, de que ela é resultado. Este fato o autoriza a pensar a esfera cultural nos moldes em que ela se configurou historicamente, isto é, segundo a sua dinâmica própria.

A questão da autonomização da cultura foi tematizada tanto por Bourdieu quanto Mannheim ao refletirem sobre a emergência dos intelectuais no mundo moderno. Para ambos, os intelectuais devem a este processo um de seus principais traços: a educação escolar, e mais especificamente, a educação acadêmica. É o que veremos a seguir, apresentando inicialmente as reflexões de Mannheim sobre $o$ assunto.

\section{EDUCAÇÃO ESCOLAR:}

\section{DESENRAIZAMENTO OU AUTARQUIZAÇÃO DO INTELECTUAL?}

Para Mannheim, os intelectuais, como profissionais da reflexão, constituem um fenômeno social moderno. A gênese deste grupo social está relacionada à destruição do monopólio da interpretação eclesiástica do mundo, e marca a última e mais complexa fase do "processo de autoconscientização dos grupos sociais" no mundo ocidental.

Devido à sua emergência tardia, a intelligentsia constituiu-se como um grupo social heterogêneo, tanto em relação a origem de seus membros, quanto às perspectivas culturais que representam.

Indubitavelmente, um dos aspectos mais polêmicos da reflexão de Mannheim é a caracterização da intelligentsia como uma camada social "livremente flutuante". Reagindo às críticas dirigidas às suas formulações iniciais - presentes em Ideologia e Utopia, publicado originalmente em 1929 -, Mannheim respondeu posteriormente, reconhecendo sua incapacidade em distinguir de forma precisa o tipo particular a que denominou intelligentsia de outros estratos sociais. Por um lado, defendeu-se das acusações afirmando que

(...) os intelectuais não constituem um estrato elevado sobre as classes e não são de modo algum mais dotados que outros grupos para superar seus próprios engajamentos de classe. Em análise anterior desse estrato, usei o termo intelligentsia relativamente descomprometida, que aceitei de Alfred Weber, sem pretender sugerir um grupo completamente desligado e livre das relações de classe. O epíteto relativo não é 
uma palavra vazia. A expressão simplesmente alude ao fato reconhecido de que os intelectuais não reagem diante de determinadas situações de modo tão coeso como por exemplo os empregados ou os operários. (Mannheim, 1976:81-2)

Por outro lado, aproveitou para reafirmar seu ponto de vista, criticando os termos do debate sobre o assunto na época. Em sua opinião, eram "estéreis" as discussões em torno do pertencimento ou não dos intelectuais a uma classe social, uma vez que este enfoque contribuía pouco para a caracterização sociológica da intelligentsia. Não era por este meio que conseguiria atingir o que lhe parecia mais pertinente: o que torna um indivíduo sociologicamente relevante?

Recusando a posição "realista de conceder prioridade a um agrupamento particular tal como classe, raça, igreja ou nação", e se opondo também à posição que subordinava a existência "de todos os agregados sociais a um agrupamento real", Mannheim postula como sociologicamente relevante a inserção dos intelectuais em múltiplos agrupamentos. Pretendendo caracterizar a intelligentsia como "um único tipo social", procura examinar as suas motivações ambivalentes e as afiliações múltiplas, considerando como seu principal atributo "o contato em graus diferenciados com a cultura" (Mannheim, 1974a:86).

É provável que a crítica não tenha levado em consideração ou tenha permanecido insatisfeita com tais argumentos. Em nosso modo de ver, faz-se necessário um reparo em favor das reflexões de Mannheim sobre o assunto. Sem pretendermos ser exaustivos, gostaríamos apenas de assinalar um aspecto desta questão que nos parece menosprezado pela literatura.

Ao afirmar que a intelligentsia "é um agregado situado entre, e não acima das classes", Mannheim não está omitindo ou renegando a origem de classe como um fator importante, como vimos em suas declarações acima citadas. Quando estabelece o programa de investigação dos intelectuais (à frente mencionado), a origem social é o primeiro ponto a ser analisado.

Em nosso ponto de vista, no entanto, ele está enfatizando um outro aspecto que lhe parece mais decisivo na caracterização que pretende fazer do tipo sociológico: o treinamento. É este que capacita o indivíduo como intelectual, e o faz "encarar os problemas do momento a partir de várias perspectivas e não apenas de uma, como faz a maioria dos participantes de controvérsias" (Mannheim, 1974a:81).

A origem social e o treinamento não são fatores excludentes, mas planos distintos de análise aos quais Mannheim confere pesos diferenciados. Ele acredita que algumas formas peculiares de socialização propiciam o desenvolvimento de determinados " estilos de pensamento e de comportamento" que confere singularidade ao indivíduo como membro da camada intelectual numa determinada situação histórica. 
Nas sociedades ocidentais o treinamento foi gradualmente sendo concentrạdo num tipo particular de experiência socializadora, a educação escolar.

Segundo Mannheim, esta experiência foi determinante para o desenvolvimento de várias formas de conhecimento esotérico, cuja "aquisição não é espontânea, mas resultou de esforços dedicados e de uma tradição cultivada" (Mannheim, 1974a:90). Assim, foram definitivamente separados a esfera do senso comum do domínio de conhecimento esotérico, gerando um distanciamento entre estas duas formas de cultura. $\mathrm{O}$ "desenraizamento" de classe atribuído por Mannheim aos intelectuais é decorrência direta dessa segunda experiência socializadora propiciada pela educação escolar. "A ambivalência do homem culto e o desvio de seu modelo de classe podem ser explicados pelo fato de que um universo distinto de discurso tende a criar um grupo unânime com um esprit de corps especial, e a aumentar a distância entre os que podem ou não se comunicar dentro desse universo adquirido de pensamento" (Mannheim, 1974a:89-90). Como vemos, a intelligentsia constitui um universo de pensamento distinto, marcado pelos vínculos que mantém com a cultura esotérica.

Este mesmo movimento de esoterização do conhecimento foi concomitante ao processo de secularização da cultura, que assinalou a ruptura do monopólio eclesiástico do saber e propiciou o surgimento de um novo tipo intelectual. Enquanto os letrados escolásticos formavam um grupo social e culturalmente homogêneo, os intelectuais modernos constituíram "um estrato social frouxo e polarizado" do ponto de vista cultural.

Para Mannheim "a chave da nova época do saber está no fato de que os homens cultos deixam de constituir uma casta ou estamento fechado, passando a integrar um estrato aberto", ao qual ganham acesso pessoas das mais variadas procedências. "Uma visão unitária do mundo já não pode mais imperar, e o hábito de pensar de dentro de um sistema escolástico fechado dá lugar ao que se pode chamar de processo intelectual", que expressa "a polarização das várias visões do mundo existentes e que refletem as tensões sociais de uma civilização complexa" (Mannheim, 1974a:91-2).

O eixo sempre variável do pensamento moderno reflete a aparição de uma intelligentsia desprivilegiada e polarizada, que repercute em si mesma todos os pontos de vista inerentes à heterogeneidade de seus antecedentes sociais. Uma vez rompido o antigo esprit de corps da escolástica e desfeita sua organização compacta, a tendência a questionar e a investigar tornou-se um traço permanente.

Parece haver um paradoxo na caracterização mannheimiana da intelligentsia moderna. Por um lado, seu surgimento implica radical esoterização do saber que tem no conhecimento científico uma expressão exemplar. Por outro, sua composição social e cultural heterogênea resultou na real democratização da produção do conhecimento e na criação de uma "cultura multipolar" (Mannheim, 1974a:93-4). 
Em nossa opinião, o paradoxo pode ser compreendido quando examinamos de perto o que Mannheim chama de efeitos positivos e negativos da educação escolar moderna. Segundo Mannheim (1974a:94),

As vantagens da educação, como as possibilitadas pela época moderna, são inequívocas. Consistem na expanso do eu através da participação de uma cultura multipolar. Um indivíduo pode viver mais que sua própria vida e pensar mais que seus próprios pensamentos. Pode elevar-se sobre o fatalismo e o fanatismo de existências solitárias, sejam de indivíduos, vocações ou nações. O preço dessa vantagem é a disposição de manter o eu em recesso, quando necessário, de repensar suas premissas e colocar um ponto de interrogação no fim dos absolutos. Não se pode apreciar a mente educada sem dar-se conta do aspecto positivo que reveste os atos exploratórios do ceticismo - compreendido este não sob a forma congelada de sistema filosófico, mas como estado de incerteza fértil.

Portanto, a formação de saberes esotéricos e/ou de uma cultura multipolar são possibilidades inerentes à educação escolar moderna como processo socializador básico do intelectual. Seus efeitos sociais são a autonomia do intelectual (esoterização) e/ou a democratização do conhecimento (cultura multipolar).

Vale lembrar que Mannheim faz uma ressalva quanto à possibilidade de democratização de algumas formas de conhecimento. Para ele "o ideal democrático de conhecimento é caracterizado pela acessibilidade ilimitada e pela comunicabilidade. Entretanto, ambas são limitadas, mesmo em culturas democráticas. Grande parte do conhecimento só é acessível a especialistas e conhecedores e só entre eles circula" (Mannheim, 1974b:153).

Este é o caso do conhecimento científico em que há, segundo Mannheim, uma nítida tendência à esoterização radical que faz da ciência um estilo de pensamento de caráter não-democrático (Mannheim, 1974b:154).

Comparativamente, no entanto, o campo científico é menos desprendido da sociedade inclusiva que o campo artístico. Segundo Mannheim (1974b:154),

a comunidade científica não se acha tão radicalmente separada da sociedade inclusiva como ocorre com a comunidade de connoisseurs estéticos. De fato, o pensamento científico é formalizado e objetivo, não dando lugar a experiências privadas e subjetivas. Em princípio, qualquer descoberta ou teoria científica pode ser apreendida e reproduzida por qualquer indivíduo normal. Se o não especialista não pode acompanhar o cientista, não é porque as experiências deste 
estejam além do alcance do primeiro, mas porque o leigo logo se perde na complexidade resultante da repetição e combinação de operações mentais básicas simples em si.

O conhecimento científico pode ser formalizado e objetivado sendo, portanto, passível de transmissão através do ensino, o que o torna mais democrático do que as formas artísticas.

É curioso que, embora Mannheim não tivesse pensado em submeter às ciências "duras" ao crivo da análise sociológica, as suas reflexões sobre os intelectuais nos autorizam a pensar os fatos científicos como fatos sociais. Ele nos indicou uma pista importante nesse sentido, tornando a investigação da forma específica de socialização do intelectual uma chave para a análise sociológica da ciência como um estilo de pensamento.

Embora não reconheça qualquer filiação ao pensamento de Mannheim, Pierre Bourdieu perseguiu suas pistas enfocando a educação escolar em seus estudos sobre a cultura ocidental.

Esta temática consiste num elo significativo entre o pensamento sociológico de Mannheim e Bourdieu. Genericamente, ambos vêem a educação escolar como um traço peculiar da formação dos intelectuais no mundo moderno. De um ponto de vista específico, no entanto, faz-se necessário qualificar as reflexões de Bourdieu que apresenta nuances diferenciadoras.

Do mesmo modo que Mannheim, Bourdieu concebe a vida cultural no mundo moderno como o resultado de um longo processo histórico de progressiva autonomização, estabelecendo uma ruptura com o padrão tradicional de relações sociais, as quais subordinavam o campo cultural a instâncias externas - como a lgreja e a aristocracia -, que a tutelavam e a comandavam em função de suas demandas estéticas ${ }^{6}$.

Nos termos de Bourdieu, isto significou a possibilidade de criação de um mercado de relações de produção e consumo, baseado em princípios e procedimentos propriamente culturais.

A libertação progressiva da esfera cultural está relacionada a uma série de transformações decisivas para a dinâmica da vida cultural, entre as quais se destacam a constituição de um público consumidor cada vez mais extenso, a diversificação de instâncias de consagração e difusão dos bens culturais, e, sobretudo, o aparecimento de um corpo de agentes numeroso e diversificado: artistas e intelectuais profissionais.

6 O processo de diferenciação das esferas da atividade humana e, em particular a constituição de sistemas de fatos dotados de uma independência relativa e regidos por leis próprias, é correlato ao desenvolvimento do capitalismo, e produziu as condições favoráveis à construção de sistemas ideológicos (as teorias puras do direito, da economia, da política, da arte etc.) que reproduzem as divisões prévias da estrutura social com base na abstração inicial através da qual eles se constituem (Bourdieu, 1987b:103). 
À medida que o campo cultural passou a funcionar como uma "arena fechada", esta categoria socialmente distinta (o intelectual em oposição ao letrado, o artista em oposição ao artesão), tendeu a pautar sua conduta por regras propriamente culturais, referidas à tradição. Tendo como base a herança cultural recebida de seus predecessores, artistas e intelectuais libertaram-se de dependências sociais, censuras morais, controles estéticos e políticos estranhos à sua produção. Cada vez mais o campo cultural se tornou impermeável a fatores de diferenciação econômica, social ou política, como a origem familiar, a fortuna, o poder, encarados como mecanismos ilegítimos pelas instâncias de consagração cultural ${ }^{7}$.

No caso do campo de produção erudita - que se diferenciou do campo da indústria cultural no processo de autonomização e que se caracteriza pela expansão de um maior mercado consumidor - a tendência no sentido de produzir as normas próprias de produção e de avaliação dos produtos foi acentuada, uma vez que o reconhecimento cultural somente pode ser concedido pelo grupo de pares que são, ao mesmo tempo, clientes privilegiados e concorrentes (Bourdieu, 1987b:105).

Deste modo, constata-se a tendência à esoterização do conhecimento, restrito a um círculo fechado de agentes possuidores exclusivos dos códigos de seu deciframento. Este é um dos traços mais peculiares do campo de produção erudita, em particular, a ciência. À luz deste fato é que a educação escolar ganha centralidade, pois tornou-se a principal forma de transmissão da cultura em geral no mundo moderno, e em especial da cultura erudita, cuja especificidade reside no modo de organização em instituições destinadas à transmissão (implícita e/ou explicitamente) de formas de pensamento manifestas ou inconscientes ${ }^{8}$.

Segundo Bourdieu, um pensador participa de sua sociedade, primeiro através do inconsciente cultural captado por meio de suas aprendizagens intelectuais, e, em especial, por sua formação escolar.

Os homens cultivados devem sua cultura à escola, que lhes fornece "um repertório de lugares comuns" - discurso e linguagem, terrenos de encontro e desencontro, problemas comuns e maneiras comuns de abordá-los. Isto faz com que exista uma concordância entre os sujeitos cultivados de uma época acerca das questões que devem constituir o debate, mesmo sobre aquilo que constituem as divergências. Conforme Bourdieu, se processa "um consenso no dissenso", cuja origem reside na tradição escolar (Bourdieu, 1987c:207) .

7 Conforme Bourdieu, o recurso a estes fatores significa romper com as regras que regem a profissão intelectual, e a desobediência a estas pode implicar uma execução simbólica, ou seja, a desvalorização e desqualificação dos bens produzidos por mecanismos considerados espúrios.

8 Para Bourdieu, a escola tem a mesma função de integração lógica que era preenchida nas sociedades primitivas pela religião, pois ela propicia aos indivíduos um corpo comum de categorias de pensamento que tornam possível o estabelecimento de um consenso cultural, condição para a comunicação entre os indivíduos. (Bourdieu, 1987c:205). 
inculcar os códigos necessários à decodificação da cultura erudita. É nesse sentido que o saber especializado, e também a cultura em geral, em vez de unificar, distingue.

Quanto mais especializado o conhecimento, maior será o distanciamento das classes cultivadas em relação às classes populares. No caso francês, Bourdieu comenta que a distinção dos indivíduos cultivados ocorreu por uma segregação que reservou o ensino secundário e superior às classes abastadas desde o final do Antigo Regime. Esta dualidade no sistema de ensino, o secundário (liceu) para os burgueses, e o primário (escola) para o povo, baseada nas condições sociais, correspondia a uma dualidade de cultura ${ }^{10}$.

Ao se referir aos aspectos distintivos promovidos pela escola e, em especial, pela educação acadêmica, Bourdieu vincula o itinerário intelectual de um sujeito às condições de constituição de seu pensamento, que sempre estão referidas historicamente a uma cultura particular, seja de grupos e classes, seja da tradição intelectual de uma nação. Isto porque seria despropositado refletir sobre o pensamento fora de suas condiçóes institucionais.

Deste modo, a fim de compreender inúmeras caraterísticas nacionais da atividade intelectual, é necessário remetê-las às tradições dos sistemas escolares, cuja especificidade deriva de uma história nacional particular, e de sua história específica no interior desta história. Assim também diferenças que separam os intelectuais poderiam ser associadas à relação que cada criador intelectual mantém com sua tradição acadêmica nacional e que depende de sua biografia escolar (Bourdieu, 1987c:227).

Julgamos que o programa da sociologia do conhecimento desenvolvido por Bourdieu tem nas reflexões a respeito da escola um ponto extremamente fértil.

Consideramos que o enfoque sobre as formas de organização e transmissão da cultura através da identificação das problemáticas obrigatórias, estilos de pensamento (pensamento de escola), famílias espirituais, tradições intelectuais de uma nação constituem categorias adequadas para pensar a historicidade do pensamento.

Ademais, pode representar um meio de acesso eficaz às explicações não somente do significado das obras intelectuais, mas também do que nelas está inscrito por participarem da simbologia de uma época. Conforme o próprio Bourdieu assinala, "o pensamento por escolas e gêneros permite organizar as coisas de escola, isto é, o universo das obras filosóficas, literárias, plásticas, e além delas, e por seu intermédio, ordenar toda a experiência do real e todo o real" (Bourdieu, 1987c:213).

10 Bourdieu observa que, no caso das classes cultivadas, a transmissão da cultura não está ao encargo apenas da escola, uma vez que elas não têm apenas esta como meio de socialização, conformando uma comunidade de cultura a partir da família de procriação. (Bourdieu, 1987c:216). 
Em outras palavras, isto significa reconhecer que a vida intelectual é governada por "um conjunto de esquemas lingüísticos e intelectuais interiorizados", que modelam o pensamento assim como o expressam. Eles "determinam o que os indivíduos apreendem como digno de ser pensado e o que pensam a respeito", selecionam e valorizam aspectos da realidade, hierarquizando objetos de estudo que são socialmente aceitos como legítimos por uma sociedade (Bourdieu, 1987c:213).

Atuando sob a forma de automatismo, estes "esquemas fundamentais" somente são apreendidos por intermédio de um retorno reflexivo sobre as operações já efetuadas. Logo, podem reger e regular as operações intelectuais sem que sejam conscientemente apreendidos e dominados (Bourdieu, 1987c:210).

Os indivíduos assim "programados" - dotados de um programa homogêneo de percepção, de pensamento e de ação - constituem o produto mais específico de um sistema de ensino. Reunidos sob o signo de um conjunto de problemáticas comuns, instituem o que Bourdieu denomina de "pensamento de escola", ou seja, um estilo de pensar que "organiza o real orientando e organizando o pensamento do real" (Bourdieu, 1987c:206). A existência destas "famílias espirituais" está intimamente relacionada ao conhecimento especializado, e o seu número pode variar de acordo com os múltiplos desdobramentos disciplinares.

Deste modo, a escola não oferece somente as indicações do que deve ser valorizado, mas também define os itinerários - os métodos e programas de pensamento, que balizam a trajetória posterior do pensamento. É por meio desta marca de aquisição dos esquemas constitutivos da cultura que se pode diferenciar o autodidata do homem formado pela escola (Bourdieu, 1987c:220).

Além de cumprir esta função de integração lógica, a educação escolar, e sobretudo, a acadêmica, tem um outro atributo: promove a distinção entre os indivíduos cultivados e as classes populares.

Como obsenva Bourdieu, a distinção social dos bens produzidos no campo de produção erudita reside na raridade dos instrumentos de seu deciframento, à diferença do campo de produção da indústria cultural, onde é indiferente o grau de instrução dos receptores, uma vez que o produto é ajustado à demanda. Note-se, no entanto, que a posse dos instrumentos necessários para o deciframento dos códigos é desigual e restrita ${ }^{9}$, em função da origem socioeconômica dos agentes, e/ou pelo acesso diferenciado às instituições escolares - que detêm o poder de

9 No campo científico em particular, Bourdieu destaca o papel determinante do título escolar como o capital inicial que pode definir o destino de uma carreira. Conforme Bourdieu, o título "encerra uma trajetória provável, e comanda, por meio de aspirações razoáveis que ele autoriza, toda a relação com a carreira científica" ao determinar as escolhas dos assuntos mais ou menos ambiciosos, maior ou menor produtividade (Bourdieu, 1983:134). 
Estas categorias correspondem a uma das mais importantes características atribuídas por Bourdieu ao mundo intelectual: o caráter fechado de uma comunidade que compartilha um "espírito comum". A autarquização - devida à autonomização deste universo mais do que qualquer outro campo social - produz um grupo que assume a feição de "uma seita ou igrejinha" (Bourdieu, 1987b.126).

É devido a este traço que se pode perceber no comportamento destes intelectuais, descritos por Bourdieu, uma tendência à auto-reprodução. Por um lado, isto significa proclamar o divórcio dos intelectuais em relação às demandas sociais, e por outro, dizer que sua prática e identidade social se definem por intermédio de sua inscrição acadêmica.

Esta concepção de Bourdieu a respeito dos intelectuais contrasta com a de Mannheim, que, ao se referir ao papel dos intelectuais, se indaga: "Afinal de contas, o intelectual é ou não meramente uma crista de onda? Pode-se esperar que o catavento controle o próprio vento?" (Mannheim, 1974a:137).

Esta imagem sintetiza a sua opinião sobre intelligentsia como "protagonistas da reflexão crítica". Ele os remete à condição de formuladores de projetos para a sociedade inclusiva. A intelligentsia "mesmo que não controle o poder nem os recursos materiais, deixa suas marcas sobre a interpretação pública dos problemas". A sua única preocupação, segundo Mannheim, é com "o processo intelectual, isto é, o esforço contínuo de avaliar, diagnosticar e prognosticar, descobrir alternativas, compreender e localizar os diferentes pontos de vista " (Mannheim, 1974a:138).

É a partir da posição que os intelectuais têm no mundo, que Mannheim desenvolve suas reflexões. Já Bourdieu enfatiza a organização do mundo dos intelectuais. Embora contrastantes, não necessariamente estas perspectivas se excluem mutuamente. Nem as consideramos complementares. Explorá-las devidamente significa, antes, poder compreender integralmente o sentido desta diferença, que, provavelmente, pode encontrar alguma explicação na singularidade de problemas e questões com que cada um se defrontou em seu próprio tempo. 


\section{Valores Sociais e Atividade Científica: um retorno à agenda de Robert Merton}

Nisia Trindade Lima

O entendimento humano não é luz seca, mas recebe uma infusão da vontade e dos afetos; daí procedem as ciências que podem ser chamadas ciências como a gente quis.

Francis Bacon apud Merton, 1970:553

$\mathrm{U}^{2}$ ma das idéias centrais do debate sobre o papel da ciência no mundo contemporâneo refere-se à natureza social do conhecimento científico. A aceitação do caráter social da ciência implica a necessidade de analisá-lo à luz dos interesses, crenças e critérios de validade compartilhados, que orientam a atividade dos cientistas e sua interação com outros atores sociais.

A despeito das intermináveis controvérsias em torno do tema do caráter da ciência e da persistência de antinomias do tipo "natural $\times$ social" e "científico $\times$ social" 1 , o debate é marcado pela presença de argumentos tipicamente sociológicos. Os que defendem o caráter convencional e contingente do conhecimento científico pouco têm aprofundado, no entanto, as relações entre a ciência e outras formas de cognição, favorecendo redundâncias e circularidade. Por outro lado, o argumento sobre a natureza social do conhecimento científico freqüentemente oculta as premissas sociológicas e as diferentes possibilidades de "construção do social" pelos analistas.

1 Este ponto é fortemente acentuado por Gieryn (1982) em resenha das perspectivas construtivistas e relativistas da ciência. Ainda que não compartilhe de todas as críticas do autor, concordo com a idéia de redundância de muitos trabalhos e com a ênfase na formulação de problemas que resgatem a especificidade da ciência entre as demais instituições produtoras de cultura. 
Lida-se, muitas vezes, com abordagens unidimensionais das ações e estruturas sociais, o que se revela pela presença de duas antinomias nos estudos de sociologia da ciência - comunidade $\times$ mercado e valores $x$ interesses ${ }^{2}$.

Sugere-se, neste trabalho, que um retorno a temáticas presentes na agenda de Robert Merton pode contribuir para o exame dessas antinomias, recuperando a importância do tema da adesão a valores na análise da atividade científica $^{3}$. A preocupação mais geral é discutir algumas questões que têm sido pouco problematizadas pela literatura mais recente em sociologia e história da ciência. Estou particularmente interessada em questionar o suposto de que normas e valores seriam de pouca relevância e pertinência explicativa, sublinhando as limitações de um modelo de análise que entende a atividade científica como ação racional de natureza instrumental ${ }^{4}$.

Trata-se, em suma, de situar a atividade científica no âmbito de um debate mais amplo, que diz respeito ao conjunto da produção sociológica, e que está presente na origem das ciências sociais (Nisbet, 1980) em torno do que Alan Dawe (1980) denomina agência humana.

O conceito de agência refere-se às possibilidades de controle e criação em um universo social marcado pela tensão entre volição, com ênfase nas práticas interativas dos indivíduos, e a noção de um sistema social constituído com anterioridade aos indivíduos, que conformaria suas crenças e práticas. É insuficiente afirmar que se trata de uma permanente atualização do par indivíduo/sociedade.

O que está em questão, nos estudos sobre a agência humana, é a possibilidade de emergência do indivíduo moderno numa perspectiva que supere as interpretações tradicionais na sociologia. Segundo um dos pressupostos correntes nessa disciplina, uma vez rompidas as bases comunais da sociedade medieval, a ação predominante, senão exclusiva, seria de tipo racional instrumental; nestas circunstâncias, a única possibilidade de constituição de um espaço público estaria na emergência de um sistema social concebido igualmente de forma instrumental (Dawe, 1980).

2 Para a análise da posição de autores como Kuhn, Bourdieu, Latour e Knorr-Cetina, em torno do eixo comunidade/mercado, ver Hochman (1993).

3 A importância dos valores como elemento de mediação entre contextos sociais e texto é sublinhada por Maria Alice Rezende de Carvalho em ensaio sobre a constituição da identidade dos intelectuais contemporâneos (cf. Carvalho, 1991). Considero possível estender o argumento para a atividade científica.

4 Estou-me referindo à tipologia da ação social elaborada por Max Weber. Para o autor, há quatro tipos de orientação para a ação: racional voltada a fins, ou racional instrumental (voltada para a realização de fins racionalmente calculados pelo ator); racional de valor (determinada pela crença consciente no valor ético, estético, religioso ou de outra natureza); afetiva (determinada pelos afetos e estado emocional) e tradicional (determinada pelo hábito arraigado). Ver Weber, 1974. Para uma discussão sobre as ambigüidades de Weber na abordagem da ação social, consultar Alan Dawe (1980). 
$\mathrm{Na}$ atividade científica, à semelhança de outras atividades sociais, o que está em jogo é a possibilidade de o homem pós-medieval realizar uma ação moral que não se contraponha à emergência do mercado e da individualidade. Isto implica, no plano da teoria social, questionar as abordagens que pressupõem a racionalidade instrumental como dimensão praticamente exclusiva da ação social. Tais abordagens pouco consideram a possibilidade de uma ação racional fundada em crenças e qualquer referência a normas e valores tende a ser vista como uma reedição consenvadora do tema da comunidade ou como um vício funcionalista de atribuição de primazia à ordem e ao sistema social.

Se um autor como Robert Merton apresenta as limitações da perspectiva estrutural-funcionalista de que participa ativamente, sua abordagem sobre o mundo moderno (caracterizado pelo conflito de valores e pela ambigüidade de motivações) pode ser vista como uma contribuição ao debate mais geral assinalado, inclusive pela crítica à redução do ator social ao homo economicus. Ao abordar a contribuição de Merton para a sociologia do conhecimento e da ciência, identifico como um dos temas mais relevantes o privilégio da ambivalência, considerada característica básica das sociedades contemporâneas e da atividade científica em particular. Preocupo-me, centralmente, com a retomada de uma agenda de pesquisa, relevante e atual, sem pretender apresentar uma defesa do conjunto de seus julgamentos e conclusóes sobre o tema, em relação aos quais muitas das críticas de que sua obra foi objeto são pertinentes.

Outra razão justifica o retorno à sociologia de Robert Merton. Raramente incluído entre os precursores dos chamados "estudos sociais da ciência", Merton talvez tenha sido o primeiro autor a incluir a sociologia da ciência no campo mais amplo da sociologia do conhecimento, de inspiração mannheimeana, problematizando a redoma em que Mannheim colocara as ciências naturais e exatas.

Abordar o conjunto das contribuições do autor para o tema em pauta certamente seria uma tarefa com alto risco de fracasso. Mais modesta, procurei resgatar algumas das idéias que me pareceram especialmente relevantes, estabelecendo, sempre que possivel, um diálogo com outras perspectivas intelectuais. A fim de tornar a exposição mais ordenada, dividi o texto em seções, iniciando com uma breve apreciação das características mais gerais da produção intelectual de Merton. Uma segunda seção é dedicada à sociologia do conhecimento, situando o diálogo do autor com a perspectiva de Karl Mannheim. Acentuo, igualmente, a influência de Weber na análise das razões de emergência de um estudo sociológico sistemático do conhecimento. A terceira seção do trabalho focaliza as principais contribuições de Merton para a sociologia da ciência, com ênfase na análise de contextos culturais e valores na atividade científica. Em continuidade, a última parte do texto indica temas e questões que podem orientar um diálogo entre as perspectivas de Merton e as que vêm predominando nos estudos sociológicos mais recentes sobre o conhecimento científico. 


\section{NOTA SOBRE A PRODUÇÃO INTELECTUAL DE ROBERT MERTON E SUA INFLUÊNCIA NA SOCIOLOGIA DA CIÊNCIA}

Robert Merton ingressou na Universidade de Harvard em 1930. Lá foi aluno, entre outros, de Talcott Parsons, de Pitirin Sorokin e do historiador da ciência George Sarton. Um de seus primeiros trabalhos foi uma resenha do livro de Usher, History of Mechanical Invention, elaborada por solicitação do professor de história econômica E.F. Gay, e publicada por Sarton na ISIS, principal periódico norte-americano de História da Ciência.

A demonstração de interesse pelo tema motivou Sorokin a convidá-lo para atuar como assistente na pesquisa que resultou na publicação de Social and Cultural Dynamics, assumindo Merton a responsabilidade pela parte relativa ao desenvolvimento da ciência. A experiência foi decisiva para a elaboração da tese Ciência, Tecnologia e Sociedade na Inglaterra do Século XVII, concluída em 1933. $O$ interesse pelas relações entre contextos sociais e sua influência na produção de idéias, inclusive científicas, também esteve presente em trabalhos de avaliação das contribuições de Durkheim, Scheler e Mannheim elaborados durante as décadas de 1930 e 1940.

Preocupações semelhantes manifestavam-se naquele contexto entre historiadores da ciência como Boris Hessen, que tentou relacionar a física newtoniana ao contexto socioeconômico da Inglaterra segundo uma perspectiva marxista ${ }^{5}$. Alguns analistas apontam a influência de Hessen na ênfase atribuída por Merton a fatores de natureza econômica na seleção de temáticas de pesquisa pelos membros da Royal Society, abordadas em sua tese sobre a institucionalização da ciência experimental na Inglaterra (Storer, 1973).

Data de 1942 uma certa reorientação no foco de pesquisas do autor, que passou a abordar a estrutura social da ciência com ênfase nas normas e valores que the caracterizariam enquanto instituição social. $\mathrm{O}$ artigo publicado originalmente com o título "A Note on Science and Democracy" representa essa mudança de ênfase. Nele aparece de forma sistemática o tema com que mais facilmente se identifica a sociologia da ciência mertoniana - o ethos científico, envolvendo os valores de universalismo, ceticismo organizado, desinteresse e comunismo (Merton, 1970) ${ }^{6}$.

5 Boris Hessen, diretor do Instituto de Física de Moscou no início da década de 1930, participou em Londres do Segundo Congresso Internacional de História da Ciência e da Tecnologia, realizado em 1931. Influenciou sensivelmente cientistas e historiadores ingleses e norte-americanos, tendo sido seu trabalho comentado por importantes cientistas britânicos (cf. Storer, 1973).

6 Uma primeira abordagem ao tema está presente no trabalho "A Ciência e a Ordem Social", apresentado à American Sociological Society Conference, em 1937 (cf. Merton, 1970). 
As pesquisas no campo da opinião pública e as tentativas de sistematização teórica e elaboração de conceitos nos marcos do estrutural-funcionalismo tornam-se progressivamente temas prioritários da agenda do autor, constatando-se uma menor atenção com o estudo sociológico da ciência e do conhecimento durante a década de 1950. Uma segunda fase de trabalhos sobre o tema tem início em 1959, quase sempre em conjunto com uma nova geração de alunos e orientandos de sociologia da ciência da Universidade de Colúmbia (cf. Storer, 1973, Cole e Zuckerman, 1975) ${ }^{9}$.

Em levantamento realizado no início dos anos 70 , procurou-se avaliar a influência dos trabalhos de Merton na produção acadêmica em sociologia do conhecimento e da ciência. Os autores constataram o predomínio da primeira fase de pesquisas sobre o tema, sendo raras as referências aos estudos característicos da segunda fase, que versam especialmente sobre competição por prioridade e ambivalência nas atitudes dos cientistas ( $c$. Coler e Zuckerman, 1975). A tendência apontada permanece atual e poderíamos ainda acrescentar que, para boa parte dos pesquisadores e estudantes, o texto de Merton mais conhecido sobre o tema é o que aborda o ethos da ciência, objeto de crítica acirrada por ser percebido como idealização da atividade científica que nada diz sobre aquilo que realmente os cientistas fazem. Veremos adiante o quanto de parcial há nesse julgamento.

O exame da produção de Merton em torno da temática do conhecimento não pode prescindir de uma avaliação mais geral de sua obra. Entre seus traços mais característicos destaca-se a incorporação da tradição sociológica européia, especialmente das obras de Durkheim, Weber, Marx, Mannheim e Simmel. Sua dívida para com este legado cultural foi reconhecida em obra dos anos 60 - On the Shoulders of Giants (Merton, 1965). ${ }^{8}$

Uma comparação com Talcot Parsons revela interessante contraste. Parsons, além de não estabelecer diálogo aberto com perspectivas teóricas tão diferentes como as dos pensadores europeus citados, aborda muito perifericamente as contribuições de Marx, Mannheim e Simmel, influências expressivas na obra mertoniana. Parsons se voltava para a formalização de uma teoria de grande alcance em que o tema da ordem social consistia no fio condutor.

Merton, por sua vez, dedicou-se às mediações entre a teoria e as possibilidades de análise em contextos socioculturais diversificados, atribuindo importância especial às teorias de médio alcance e problematizando o tema da ordem em uma direção sensivelmente distinta da de Parsons. Preocupava-se com as contra-

7 Uma bibliografia das obras de Merton em sociologia da ciência, incluindo os trabalhos publicados até 1973, pode ser consultada em Merton, 1973. Para uma bibliografia completa do autor e de comentários sobre sua obra, ver Miles, 1975.

8 Merton utiliza-se de uma expressão de Newton que situara de forma semelhante sua contribuição ao desenvolvimento da física e da ciência moderna. É interessante observar que referências a expressões e mesmo metáforas de cientistas é algo muito característico do estilo intelectual de Merton. 
dições e conflitos nas estruturas e as ambivalências nas motivações e percepções dos atores. Se o ator social parsoniano é o suporte de um papel estruturalmente determinado, $\mathrm{o}$ ator de Merton "movimenta-se em um universo marcado por expectativas contraditórias, muitas vezes incongruentes com sua posição social" (Coser, L. 1975:89).

Uma interessante forma de apresentar o contraste entre os principais expoentes do estrutural-funcionalismo norte-americano encontra-se na metáfora de Isaiah Berlin (1959) sobre dois estilos intelectuais polares - o ouriço e a raposa. Reportando-se a estas imagens, Lewis Coser (1975) associa Parsons ao ouriço ${ }^{9}$ - sabedor de uma única grande coisa e obsessivo em seu tratamento aprofundado de um tema. Já Merton é associado à raposa - uma mentalidade mais aberta e plástica a diferentes tendências intelectuais e objetos de investigação.

Também em conformidade às opiniões de alguns analistas da obra mertoniana, é possível sublinhar a ironia do fato de sua contribuição em vários aspectos se aproximar a de autores pouco identificados como precursores do estrutural-funcionalismo. O ponto é sublinhado com clareza por Rose Coser em seu estudo sobre a contribuição de Merton para a análise do individualismo moderno:

Merton stands in a long tradition, from Vico to Hegel and Marx, that stresses conflict and contradiction in society. But he has gone further in the building of a theory because he has attempted to specify and locate disjunctions, contradictions, and conflicts within the social structure (Coser, 1975:238).

É esta posição epistemológica que torna mais clara sua reformulação do conceito durkheimeano de anomia. A importância atribuída por Durkheim à incongruência entre a propensão humana de busca de satisfação de desejos ilimitados e a ausência relativa de controle social foi transformada por Merton na contradição entre metas culturalmente prescritas e os meios sociais disponiveis para atingi-las. Deixa-se, portanto, de lidar com o problema de coerção social e internalização de normas para se confrontar com a discrepância entre normas e valores, de um lado, e posições sociais, de outro. O estudo típico nessa perspectiva é o que se refere à ênfase norte-americana no sucesso material. De acordo com Merton, essa característica cultural contrasta com o sistema de classes, de forma que a estrutura social exerce uma pressão que favorece a emergência de comportamentos não-conformistas (Merton, 1970:241-245).

9 O significado metafórico usual de ouriço na língua inglesa é o de pessoa fechada, sorumbática. 
Os estudos em sociologia do conhecimento e da ciência orientaram-se pelos eixos centrais de sua obra: a temática da ambivalência, a distinção entre os planos institucional e motivacional e os efeitos não antecipados das ações sociais. É o que procuro examinar aqui.

\section{INTELLICENTSIA E VALIDAÇÃO DO CONHECIMENTO: A CRÍTICA A MANNHEIM}

Ao discutir as razões do maior interesse que a sociologia do conhecimento despertava, na década de 1930, Merton retoma a discussão de Max Weber a respeito do lugar da ciência no mundo moderno. As semelhanças com o argumento do conflito inconciliável de valores presente em A Ciência como Vocação são notáveis. Em sua célebre conferência, Weber analisa a natureza do trabalho científico e os dilemas experimentados pelo cientista/intelectual em um mundo que se racionalizava. $O$ processo de racionalização não indicaria um conhecimento maior e mais amplo das condições de vida, mas a crença na possibilidade desse conhecimento; significava que o mundo se desencantara (Weber, 1974).

Qual o valor da ciência neste mundo desencantado? Segundo Weber, ela não oferece respostas para indagações básicas da aventura humana: qual o sentido de conhecer as leis últimas dos acontecimentos cósmicos? A vida vale a pena - e quando? Vale a pena conhecer os fenômenos históricos e culturais?

A crítica à atividade publicista de idéias políticas pelo professor em sala de aula é enfatizada e atribuída à impossibilidade de conferir cientificidade a qualquer juízo de valor: "a defesa "científica" é destituída de sentido em princípio porque as várias esferas de valor do mundo estão em conflito inconciliável entre si" (Weber, 1974:175).

A explicação de Merton para a crescente importância da sociologia do conhecimento apresenta afinidades relevantes com o argumento weberiano sobre o lugar da ciência no mundo moderno:

\footnotetext{
A sociologia do conhecimento assume interesse sob um complexo definido de circunstâncias sociais e culturais. Ao aumentar o antagonismo social, as diferenças nos valores, nas atitudes e nos modos de pensar dos grupos aumentaram até o ponto em que a orientação que esses grupos tiveram previamente em comum é eclipsado por diferenças incompatíveis (Merton, 1970:555).
} 
Ao discutir as características das análises sobre o tema, novamente é o conflito de valores que aparece em destaque. Merton indica uma aproximação significativa entre tradições teóricas distintas no que se refere ao estatuto atribuído às idéias:

(...) seja qual for a intenção dos analistas, suas análises tendem a possuir uma qualidade azeda: tendem a acusar, secularizar, ironizar, satirizar, alienar o conteúdo intrínseco da crença ou ponto de vista confessado. O que estes sistemas de análise têm em comum é a prática de descartarem o valor nominal das declarações, das crenças e dos sistemas de idéias, reexaminando-os dentro de um contexto novo que proporciona o 'significado real' (Merton, 1970:566).

Os intelectuais se aproximariam dessa forma das percepções do senso comum:

Numa sociedade em que a desconfiança recíproca encontra expressões populares tais como 'quanto ele vai ganhar por is-

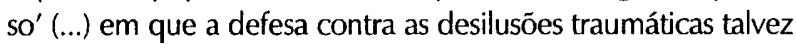
consistam em estarmos permanentemente desenganados, reduzindo as expectativas sobre a integridade de outros, dando por descontados de antemão seus motivos e talentos; - numa sociedade assim, a análise sociológica sistemática e uma sociologia do conhecimento derivada assumem uma pertinência e convicção socialmente fundamentadas (p.566)

Merton considera diferentes contribuições ao desenvolvimento da sociologia do conhecimento, detendo-se nos insights de autores como Marx, Engels, Durkheim, Scheler, Sorokin e especialmente Mannheim. Observa que estes autores remetem-se a uma concepção segundo a qual o conhecimento não é determinado imanentemente, podendo, em alguns aspectos, ser explicado por fatores extracognitivos e originando-se de uma base existencial ${ }^{10}$.

Duas tradições de estudos sistemáticos no campo da sociologia do conhecimento são apontadas: a francesa e a alemã, representadas respectivamente por Émile Durkheim e Karl Mannheim ${ }^{11}$. No caso de Durkheim, Merton observa a

10 Em seu paradigma da sociologia do conhecimento, a base existencial é um dos tópicos centrais, localizando-se, de acordo com a perspectiva de análise, na classe social, no ethos comum, na geração, na mobilidade social, ou em outros fatores.

11 De especial interesse é a comparação entre a sociologia do conhecimento de matriz européia e a sociologia da opinião em voga nos Estados Unidos na década de 1940. O tema sugere um ensaio de sociologia do conhecimento sobre as duas tradições intelectuais em sua interface com as caraterísticas sociais distintas do contexto europeu e do norte-americano, bem como das formas diferentes de organização e institucionalização do trabalho intelectual. 
continuidade das reflexões de As Formas Elementares da Vida Religiosa nos trabalhos de Marcel Mauss e Lévi-Bruhl, voltados especialmente para categorias de pensamento das sociedades primitivas ${ }^{12}$. O problema apontado consiste na correlação mecânica estabelecida entre organização social e categorias de pensamento.

Para os fins deste trabalho, importam os comentários de a Sociologia do Conhecimento, de Karl Mannheim. Segundo Merton, Mannheim segue a tradição marxista até o ponto de isentar as "ciências exatas" e o "conhecimento formal" da determinação existencial, mas não o "pensamento histórico, político e da ciência social, bem como o pensamento da vida diária" (Merton, 1970:567). Sua crítica a Mannheim dirige-se a aspectos substantivos e a controvérsias quanto às conseqüências epistemológicas da sociologia do conhecimento.

Do ponto de vista substantivo, Merton considera vaga a definição das bases existenciais, suas conexões com categorias de pensamento e a delimitação de tipos diferentes de conhecimento. Destaca como viés presente na análise de Mannheim a referência praticamente exclusiva a aspectos culturais e às ciências sociais. Outro problema apontado por Merton consiste em se considerar os interesses como fator explicativo das bases existenciais do pensamento. Afirma que uma correspondência direta entre interesses (definidos sobre que bases?) e idéias, contestada tanto por Marx como por Mannheim, aparece implicitamente nos trabalhos deste último.

O fato foi reconhecido em alguns trabalhos de Mannheim ${ }^{13}$, que abordam condições prévias (ou possibilidades) e não condições necessárias e suficientes para a emergência de sistemas de idéias. É o caso de suas reflexões sobre mobilidade social como fator de propensão a mentalidades mais abertas à mudança. Mannheim estava consciente de que uma correspondência direta entre interesses e conhecimento colocava para as ciências sociais dilemas de difícil solução.

O mesmo tema, discutido em profundidade na década de 1940, é retomado por Merton, nos anos 70 , em sua instigante crítica das perspectivas excludentes dos insiders e dos outsiders enquanto sujeitos do conhecimento. $\mathrm{O}$ autor focaliza o crescimento de movimentos sociais cuja identidade fundava-se em status atribuídos - sexo, cor etc., contestando posições, então em voga na academia norte-americana, que chegavam ao paroxismo de defender que apenas negros poderiam realizar estudos sociológicos sobre a condição negra, mulheres sobre a condição feminina e assim por diante. Mertom relembra a célebre afirma-

12 Uma recuperação da perspectiva de Durkheim para a análise sociológica da ciência encontra-se na Escola de Edimburgo, particularmente na obra de David Bloor (1976).

13 Especialmente Essays on Sociology of Knowledge.Ver Mannheim, 1952. 
ção de Weber para quem "não é preciso ser Cesar para entender Cesar", chamando atenção para a fragilidade dos argumentos tanto dos que defendiam a experiência direta como dos que defendiam o distanciamento existencial como precondição da análise social (Merton, 1973).

Deixando de lado as versões mais caricaturais, estamos diante do problema das implicações epistemológicas da sociologia do conhecimento, sobretudo do relativismo. Merton comenta as respostas de Mannheim aos que criticavam a natureza relativista da Wissenssoziologie, discutindo os três fatores apresentados pelo sociólogo alemão: critérios dinâmicos de validade, relacionismo e garantias estruturais de validade.

Os critérios dinâmicos de verdade referem-se à historicidade. Para Mannheim, uma teoria é errônea se, em determinada situação prática, emprega conceitos e categorias que impeçam o homem de se adaptar àquela etapa histórica. Nesta linha, insere-se a discussão manheimeana em torno de dois conceitos centrais - ideologia e utopia. O pensamento utópico, em contraste com o ideológico, não é ilusório. Mas, como adverte Merton:

Como fará o observador, em determinado momento, para discriminar entre o pensamento utópico válido do pensamento ideológico deformado? (...) Ademais, uma vez que, como acabamos de ver, as concepções podem ser 'inadequadas à situação por se anteciparem a ela', como se podem escolher as 'idéias antecipadas valiosas' entre as idéias antecipadas não válidas? (Merton, 1970:601)

As respostas de Mannheim ao problema seriam satisfatórias, uma vez que pressuporiam um julgamento ex post facto da adequação das idéias à ordem social.

Outro problema de natureza epistemológica relevante é o relacionismo relações da gênese de um enunciado com seu significado. $O$ conceito mannheimeano básico aqui é o perspectivismo. Segundo Merton, é substancialmente o conceito rickert-weberiano de Webeziehung: os valores são relevantes para a formulação do problema científico e a escolha dos materiais, mas são irrelevantes para a validez dos resultados (Merton, 1970:604).

Se Mannheim considera que o problema da validade do conhecimento não pode ser dissociado da existência real de perspectivas diferentes, resta a questão de como avaliar os méritos de idéias e julgamentos. Em suma, persistem obstáculos para o que chamou "sínteses dinâmicas das opiniões divergentes". A garantia estrutural da validade do pensamento social estaria na posição sem classe dos "intelectuais socialmente independentes". A crítica de Merton resume o caráter problemático do argumento de Mannheim: 
O papel da 'inteligência' torna-se uma espécie de paliativo tranqüilizador para um relativismo implícito. Os intelectuais são observadores do universo social que olham para ele, senão com desapego, pelo menos com uma penetração que merece confiança e com olhos sintetizadores (Merton, 1970:605).

A analogia com o papel do proletariado na análise marxista é sublinhada por Merton de forma pertinente e nos remete ao ponto de origem do debate aqui proposto - relacionar o tema do conhecimento ao da agência humana. Conhecimento e ação moral são termos intimamente relacionados tanto na obra de Marx como na de Mannheim. Como se sabe, na perspectiva marxiana as possibilidades de um conhecimento socialmente válido e da emergência do interesse geral estavam potencialmente presentes no proletariado. Para Mannheim, caberia aos intelectuais a validação do conhecimento e, por sua posição intersticial, a construção de um espaço público.

Merton conclui sua análise da sociologia do conhecimento de Mannheim acentuando que, apesar das ambigüidades, imprecisóes e problemas apontados, a contribuição do autor é crucial para o desenvolvimento de reflexões teóricometodológicas e para o desenvolvimento de investigações empíricas sobre as relações entre conhecimento e estrutura social ${ }^{14}$.

Uma das conseqüências mais significativas da leitura que Merton faz da sociologia do conhecimento de Mannheim consiste na possibilidade de estender seus argumentos para o conjunto das ciências. $O$ ponto de partida estava na hipótese de que "até mesmo as verdades tinham que ser consideradas socialmente explicáveis" (Merton, 1970:557).

As possibilidades de ampliar o escopo das questões colocadas pela sociologia do conhecimento requeriam uma análise mais matizada sobre os diferentes tipos de conhecimento. Isto, na perspectiva mertoniana, tornaria possível o empreendimento cognitivo do cientista social no campo das ciências naturais e exatas. Reproduzindo o argumento do autor:

Se Mannheim tivesse esclarecido sistemática e implicitamente sua posição a este respeito, teria estado menos disposto a supor que as ciências físicas são completamente imunes a influências extrateóricas e, correlativamente, menos inclinado a sustentar que as ciências sociais estão particularmente expostas a essas influências (Merton, 1970:596).

14 Merton lembra, ainda, que a epistemologia da Wissenssoziologie estava presente no pensamento norte-americano, mais precisamente no pragmatismo de Pierce e James, influenciado ainda por Dewey e George Mead. Para essa escola, "o pensamento se considera como uma atividade (...) inevitavelmente vinculada à experiência e compreensível somente em suas relações com a experiência não cognoscitiva." (Merton, 1970:606). Para uma análise dessa escola, ver, ainda, Mills (1974). 
É esta compreensão que torna possível definir a sociologia da ciência como uma subdivisão da sociologia do conhecimento voltada para o estudo da ambiência social dos conhecimentos especializados originários da experimentação e da observação controladas (Merton, 1970:631).

\section{AS CONTRIBUIÇÕES DE ROBERT MERTON À SOCIOLOGIA DA CIÊNCIA}

Como interagem ciência e cultura? É possível falar de uma interdependência entre a ciência e outras instituições sociais? Em que medida essas influências atuaram em diferentes tempos e lugares? Encontram-se caracteristicamente nas primeiras etapas de uma disciplina científica? Quais são as diversas conseqüências, tanto para a ciência como para a estrutura social, das diversas normas mediante as quais se adotam os problemas para a pesquisa?

As perguntas formuladas por Merton acompanham as pesquisas realizadas ao longo da sua trajetória intelectual. De seu primeiro trabalho de vulto - Ciência, Tecnologia e Sociedade na Inglaterra do século XVII - até os estudos dos anos 70, dedicados a uma autocrítica das análises anteriores e ao estudo da ambivalência no comportamento dos cientistas, é possível constatar a preservação de uma mesma agenda de pesquisa.

A seguinte hipótese pode ser identificada como fio condutor do conjunto de sua obra - a interdependência face a outras instituições e esferas culturais é mais forte nos momentos iniciais de institucionalização da ciência, quando se dá a afirmação da crença social no seu valor. $\mathrm{O}$ grau de autonomia tende a ser maior à medida que se verifica o avanço de um campo de conhecimentos e sua caracterização como um fim em si mesmo. Assim, o que apresentei inicialmente como uma reorientação de foco de investigação - do contexto sociocultural para o interior da comunidade científica - corresponderia à hipótese que orienta suas reflexões sobre o tema ${ }^{15}$.

Esta forma de apresentação do problema é uma simplificação do argumento do autor que deve ser feita com cuidado, mesmo porque as hipóteses de

15 É possível, aqui, identificar uma nítida semelhança com a argumentação de Thomas Kuhn sobre a ciência normal, conceito fortemente associado ao amadurecimento de uma disciplina científica. Há indicações de que as relações entre Merton e Kunh envolveram um diálogo intelectual intenso, tendo o primeiro recomendado $A$ Estrutura das Revoluções Científicas para publicação na International Encyclopedia of the Social Sciences. É interessante ainda observar que Merton dedicou à obra espaço significativo em sua memória sobre a constituição da sociologia da ciência. $O$ autor chama atenção para a importância do ambiente intelectual norte-americano e a tradição de estudos em história e sociologia da ciência na análise de Kuhn sobre o desenvolvimento da ciência (Merton, 1977). Referências à correspodência entre Merton e Kuhn podem ser encontradas em Coler \& Zuckerman (1975). 
natureza analítica sempre são matizadas em sua obra por argumentações e hipóteses de feição histórica. Assim, seria totalmente equivocado the atribuir uma visão ingênua de avanço linear da afirmação social da ciência. Ele aponta, inclusive, tendências ao anti-intelectualismo, especialmente nos trabalhos elaborados no contexto de ascensão do nazi-facismo. A afirmação do valor da ciência não teria por origem características imanentes ao conhecimento, mas seria um produto cultural. Novamente verificamos a influência da perspectiva weberiana: "a crença no valor da verdade científica não procede da natureza, mas é um produto de determinadas culturas" (Merton, 1970:637).

O que parece corresponder melhor à interpretação de Merton é o fato de a autonomia, ainda que aparente ou relativa, constituir-se como crença e orientar as atividades dos cientistas. Talvez neste ponto, à semelhança de outros abordados em sua obra, estejamos diante do seguinte postulado: a crença em determinados fatos os institui como verdade (Merton, 1970:515:531) ${ }^{16}$. A passagem a seguir torna mais claro o argumento:

Três séculos atrás, quando a instituição da ciência pouca justificação podia apresentar para conseguir o apoio da sociedade, os filósofos naturais eram levados assim mesmo a justificar a ciência como um meio para fins culturalmente válidos de utilidade econômica ou de glorificação de Deus. O cultivo da ciência não era então um valor evidente por si mesmo, mas, com a interminável corrente de êxitos obtidos pela ciência, o instrumental se transformou em final, os meios se transformaram em fins. Assim fortalecido, o cientista chegou a considerar-se independente da sociedade e a encarar a ciência como empresa que se justifica por si mesma (...) Era necessário que se desse um ataque frontal contra a autonomia da ciência, para se transformar esse isolacionismo otimista em participação realista no conflito das culturas (Merton, 1970:652).

O caráter problemático da autonomia da ciência é postulado pelo autor que, como veremos, acentua a interdependência da ciência contemporânea, apontando inclusive a formação de complexos político-militares-científicos após a Segunda Guerra Mundial. E a importância dos contextos socioculturais não é negada nos trabalhos sobre ethos científico em que considera ser a realização de

16 O tema é abordado em um dos capítulos de Sociologia: Teoria e Estrutura, em que retoma o teorema do sociólogo norte-americano, W. Thomas: "Se os indivíduos definem as situações como reais, elas são reais em suas consequiências"(Merton, 1970: 515). 
valores em grande parte condicionada pelo contexto social mais abrangente. Um valor como o universalismo, por exemplo, só poderia se realizar plenamente numa ordem social democrática.

O estudo de contextos socioculturais de desenvolvimento da ciência tem em Ciência, Tecnologia e Sociedade na Inglaterra do século XVII um modelo de análise privilegiado. Originalmente concebida como investigação sobre a influência da ética protestante no desenvolvimento de uma mentalidade favorável ao desenvolvimento da ciência, a tese acabou por incluir também a avaliação da influência de fatores econômicos na definição dos problemas de pesquisa pelos cientistas.

Merton situa a tese como a retomada de indicações sugeridas pela obra de Weber - A Ética Protestante e o Espírito do Capitalismo - resumindo da seguinte forma seu ensaio:

A ética protestante, como expressão típica ideal das atitudes para com os valores fundamentais do protestantismo ascético em geral, canalizou os interesses dos ingleses do século XVII de maneira a constituírem um elemento importante do cultivo da ciência. Os arraigados interesses religiosos na época exigiam, em suas inelutáveis implicações, o estudo sistemático, racional e empírico da natureza para glorificar a Deus em suas obras e para o controle do mundo corrupto (Merton, 1970:676).

Para testar sua hipótese básica, Merton analisa a formação da Royal Society of London e outras fontes pertinentes ao tema, acentuando a presença de puritanos ingleses e pietistas alemães entre os principais cientistas de seus países. Recorrendo a textos de Boyle, Bacon, entre outros, observa que:

O empirismo e o racionalismo foram, por assim dizer, canonizados e beatificados. É possível que o ethos puritano não tivesse influenciado diretamente e que fosse simplesmente um desenvolvimento paralelo na história interna da ciência, mas é evidente que, mediante a compulsão psicológica para certos modos de pensamento e conduta, este complexo de valores tornou recomendável uma ciência empiricamente fundamentada, e não, como no período medieval repreensível ou apenas tolerada (Merton, 1970:680).

A resposta a críticas dirigidas à tese inclui uma observação pertinente para os trabalhos que envolvem, em algum nível, análises de discursos 
de cientistas. Problematizando a utilização de textos dos membros da Royal Society of London, Merton observa que o questionamento à veracidade das motivações que informariam o comportamento dos cientistas desconsideram o fato de que as racionalizações podem ser vistas como provas dos motivos considerados socialmente aceitáveis.

Digno de menção é o fato de os textos originais de Calvino e outras lideranças religiosas conterem afirmações hostis ao desenvolvimento da ciência. Estamos, mais uma vez, diante dos efeitos não antecipados das ações sociais. Segundo Merton, trata-se de estabelecer a necessária distinção analítica entre as motivações subjetivas e as conseqüências objetivas do comportamento.

A interdependência da ciência face a outras instituições sociais não se limitaria à influência do ethos protestante. Boa parte do trabalho foi dedicada ao estudo do impacto de fatores econômicos e militares na agenda de pesquisa da Royal Society (Merton, 1973:177) ${ }^{17}$.

A atualidade de sua tese é lembrada por Merton em artigo elaborado em 1970. Ao afirmar que a hipótese sobre a interdependência da ciência em relação a outras esferas culturais, não se orientava por uma explicação unidimensional, chama atenção para a variabilidade histórica da interdependência. As características da atividade científica no século XX, inclusive a organização institucional em grandes grupos de pesquisa, diferiam sensivelmente do momento original de institucionalização da ciência experimental na Inglaterra, no entanto, a configuração de um complexo industrial-científico-militar, especialmente nos Estados Unidos e na União Soviética, atestariam a atualidade do tema da interdependência.

Em seus trabalhos sobre o ethos da ciência, Merton retorna ao tema da crença no valor da atividade científica posto originalmente por Weber. Creio ser impossível analisá-los sem considerar o contexto em que foram elaborados. Trata-se, sobretudo, de uma resposta à hostilidade à ciência, no momento de ascensão de concepções totalitárias. É interessante, dessa forma, a referência à apropriação da sociologia do conhecimento manheimmiana por intelectuais alemães e soviéticos:

É de considerável interesse o fato de que os teóricos totalitários tenham adotado as doutrinas relativistas da Wissenssoziologie como recurso político para desprestigiar a ciência 'liberal', 'burguesa', ou 'não-ariana' (Merton, 1970:643).

17 Merton recorre ao método elaborado por George Sarton para análise de textos, envolvendo mensuração das principais referências e temas abordados. Ver Merton (1973: 177). 
Trata-se de examinar a associação entre ciência e estrutura social democrática. Só dessa forma faz sentido a discussão sobre os imperativos institucionais da ciência: universalismo, comunismo, desinteresse e ceticismo organizado, que compreendem o ethos da ciência moderna. Por ethos científico, Merton compreende o complexo de valores e normas afetivamente tonalizado que se constitui em obrigação moral para o cientista (Merton, 1970:652).

O universalismo encontra expressão imediata no cânon de que as pretensões à verdade, quaisquer que sejam suas origens, têm que ser submetidas a critérios impessoais preestabelecidos. O comunismo diz respeito à norma que defende a socialização das descobertas e dos produtos científicos. O terceiro imperativo institucional apontado - desinteresse - refere-se mais ao controle dos pares do que à atitude individual dos cientistas e, finalmente, o ceticismo organizado significa o exame das crenças a partir de critérios lógicos e empíricos (Merton, 1970:653-62).

Merton, em vários momentos, afirma que o ethos da ciência não corresponderia às motivaçōes do cientista que, com alguma freqüência, mostrava-se egoísta, etnocêntrico e pouco cético. Tratava-se, segundo o autor, de um padrão típico de controle institucional que impunha constrangimentos à atividade científica ${ }^{18}$.

Vê-se, então, que o ethos da ciência não corresponde perfeitamente ao comportamento efetivo dos cientistas, mas fica a pergunta se os imperativos institucionais apontados correspondem de fato às características que moldam a atividade científica. Várias críticas poderiam ser abordadas, mas é no que diz respeito ao comunismo que a análise se revela mais problemática: a propriedade intelectual contrasta fortemente com a noção de um conhecimento compartilhado em bases comunitárias.

Estamos diante de problemas derivados, em grande parte, da abordagem estrutural-funcionalista. Ainda que Merton se individualize entre os autores desta perspectiva teórica, valorizando contradições, conflitos e ambivalências no comportamento social, sua análise dos imperativos institucionais da ciência nos remete à noção de um sistema de normas sociais de difícil correspondência com as características da prática científica.

De qualquer forma, os imperativos institucionais da ciência não podem ser abordados como meras ficções, podendo ser vistos inclusive como recursos cognitivos para uma defesa ideológica da atividade científica, com implicações na prática social. De fato, à época em que Merton escreve seus primeiros artigos sobre o ethos da ciência, diversas associações científicas empregavam argumentos semelhantes em seus posicionamentos públicos. O que se pretende ressaltar

18 O tema da regulamentação da propriedade intelectual é enfatizado por Hochman (1993). 
é o fato de interpretações sobre a natureza da atividade científica poderem ser vistas como prescrições éticas com conseqüências relevantes para a vida social.

A crítica à perspectiva mertoniana sobre o ethos científico tem, geralmente, descartado qualquer valor heurístico às normas e valores sociais, que seriam quando muito resultados da ação interessada e estratégica dos cientistas (cf. Bourdieu, 1975; Latour, 1983) ${ }^{19}$. Uma forma mais adequada de abordar o tema, escapando de uma oposição entre valores e interesses, está em reconhecer diferentes bases de constituição dos interesses e a natureza quase sempre conflitiva e ambivalente da prática científica. Um tema como o da socialização dos cientistas no interior de uma determinada tradição em que se compartilham normas e valores poderia, desde que reconhecidos o grau de variabilidade e a ambigüidade apontados, contribuir inclusive para explicar diferenças de estilos e práticas em diversos campos do conhecimento 20 .

A abordagem do ethos científico ganha um tratamento mais refinado na segunda fase dos escritos em sociologia da ciência de Merton, em que são contrastadas as estruturas de oportunidade para a atividade científica e as normas sociais. À semelhança do argumento que relaciona a anomia à meta do sucesso material na sociedade norte-americana, o autor identifica a competição por prioridade como um dos traços característicos do comportamento dos cientistas. Merton observa a tendência ao reconhecimento crescente dos cientistas já consagrados ${ }^{21}$, o que determinaria a ambivalência entre a busca de sucesso pessoal e os valores preconizados pelo ethos científico.

Merton acentua a dificuldade de os estudos em história da ciência reconhecerem a disputa por prioridade nas descobertas e na formulação de teorias científicas, particularmente no que se refere aos fundadores de novas disciplinas.

19 Com enfoques radicalmente distintos, Pierre Bourdieu e Bruno Latour convergem na noção de que o comportamento de um cientista é similar a de um investidor de capital. Para Bourdieu um investidor de "capital simbólico." Uma crítica às perspectivas destes autores em torno de problemas semelhantes aos abordados neste trabalho pode ser vista em Hochman, 1993.

20 Estou-me referindo a uma das dimensões mais ricas da análise de Thomas Kuhn, para quem normas e valores são fatores centrais na constituição da comunidade científica e da ciência normal. Foge aos objetivos deste texto proceder uma análise sistemática dos trabalhos que, em contraste com a perspectiva de Kuhn e Merton, partem da representação da atividade científica como mercado e vêem o comportamento dos cientistas em bases estritamente instrumentais. $O$ que importa observar é a abstração dos cientistas "concretos" que participam inclusive de campos disciplinares com diferentes estilos e valores. Para uma discussão sobre a relevância de tradições e ethos contrastantes na antropologia e na ciência política. Ver Soares (1993).

21 Trata-se do que definiu como efeito Mateus - sistema de recompensas e reconhecimento que privilegia os cientistas já consagrados. Os trabalhos sobre o tema estão baseados em fontes como biografias dos cientistas, atribuições de prêmios, inclusive do Prêmio Nobel. Ver especialmente Merton, 1973:439. 
descobertas, chamando atenção para as controvérsias em que estiveram envolvidos cientistas de diferentes áreas de conhecimento como Newton, Halley, Freud, Saint-Simon e Kelvin. Acentua os limites das abordagens tradicionais em história da ciência que teriam como ponto de partida uma noção idealizada do comportamento dos cientistas. As disputas por prioridade não podem ser explicadas, segundo o autor, por características de personalidade de cientistas individuais, mas pela dimensão institucional da ciência que define a originalidade como um valor supremo (Merton, 1973: 286-342) ${ }^{22}$.

A busca de prioridade não é, no entanto, infensa a tensões originárias de outros valores que informam a prática científica e orientam a socialização dos cientistas. Problematizar uma visão unidimensional das respostas possíveis ao que denomina imperativos institucionais é uma das contribuições mais significativas do autor.

Temos, assim, a possibilidade de construir visões alternativas àquelas que acentuam o caráter instrumental inequívoco do comportamento dos cientistas.

Um tema menos presente e raramente lembrado da obra de Merton consiste na abordagem de aspectos substantivos das teorias científicas. Se a Revolução Copernicana é lembrada como um marco que atesta as determinações sociais das teorias ${ }^{23}$, encontramos efetivamente poucas referências à construção de conceitos e hipóteses explicativas. Uma exceção importante encontra-se em Thematic Analysis in Science: Notes on Holton's Concept, que aborda questōes substantivas do conhecimento e explicita a crítica de Merton às propostas relativistas. O autor afirma que se orienta pela noção de uma acumulação seletiva dos conhecimentos científicos, opondo-se a um relativismo radical, como transparece na seguinte passagem:

Sociologists of science have adopted the assumption of a selective accumulation of the stock of scientific knowledge. This notion does not pressupose an inexorable unilinear advance of knowledge or a royal road to knowledge, without garden paths. It only rejects the notion of a total relativism wich, for example, would make contem-

22 Um estudo interessante, mas que vai além dos objetivos deste trabalho, é comparar as perspectivas de abordagem do tema das controvérsias científicas em Merton e Bruno Latour, que vem se dedicando a examiná-las do ponto de vista do processo de construção do fato científico numa escala microsociológica. Ver especialmente Latour (1984).

23 Este ponto é enfatizado em sua análise da sociologia do conhecimento. Ver Merton (1970:554). 
porary astronomical knowledge just another alternative to Ptolemaic astronomical knowledge, no better, no worse, justdifferent(Merton, 1975:357).

Neste ponto, fica evidente a distância que separa as posições de Merton de algumas das perspectivas mais influentes nos estudos atuais em sociologia da ciência. Refiro-me aqui, às análises de Thomas Kuhn (1978), com sua noção de incomensurabilidade dos paradigmas, e às da Escola de Edimburgo que, indo além dos argumentos de Kuhn, ressaltam tanto o relativismo do conhecimento científico como a similaridade entre a ciência e outras formas de conhecimento ${ }^{24}$. De particular interesse é obsenvar a valorização positiva da atividade científica por Merton. A associação entre ethos científico e ordem democrática, a crítica ao antiintelectualismo, entre outras questões abordadas em sua obra, estão fundadas na crença na superioridade cognitiva da ciência comparada a outras formas de conhecimento.

A breve exposição das contribuições da obra do autor para a sociologia do conhecimento e da ciência pretendeu indicar a relevância e atualidade de suas temáticas e abordagem. Compará-las de forma mais sistemática àquelas que vêm predominando em estudos atuais pode contribuir para o estabelecimento de um diálogo intelectual entre perspectivas vistas com freqüência como excludentes e inconciliáveis. Pretendendo apenas apontar questões iniciais para o debate proposto, abordo a seguir, a título de conclusão, aspectos centrais da obra do autor no contexto da produção atual em sociologia da ciência.

\section{MERTON E O DEBATE ATUAL EM SOCIOLOGIA DA CIÊNCIA}

A questão central da sociologia do conhecimento de Merton é saber como a ciência se afirmou culturalmente no século XVII e se mantém como a principal instituição promotora de cultura (Gieryn, 1982) ${ }^{25}$. A especificidade do conhecimento científico, comparativamente a outras formas de cognição, é acentuada, ao menos no que se refere à crença social em seu valor.

A despeito de o autor analisar aspectos substantivos de teorias científicas, em trabalhos da década de 1970, o foco de suas principais investigações direcio-

24 Uma apresentação dos pressupostos dessa escola, também conhecida pela adesão ao chamado programa forte de sociologia da ciência pode ser vista em Bloor (1976). Para o exame das contribuições da Escola de Edimburgo ver Palácios (1992).

25 Muitas das questōes abordadas nessa sessão foram sugeridas pela crítica de Gieryn aos programas construtivistas e relativistas em sociologia da ciência, pelas respostas dos representantes desses programas e pela réplica de Gieryn. Os artigos foram publicados na Social Studies of Science, Londres e Beverlly Hills, vol.12,1982. 
na-se para o contexto social e as normas e valores que orientam a atividade científica. Como a segunda fase da produção de Merton em sociologia da ciência é muito pouco conhecida, tende a predominar a percepção de que seria estéril um diálogo entre as suas contribuições e a dos que se voltam para a análise do conteúdo do conhecimento científico. Estaríamos, na verdade, diante de problemas de natureza diversa que não aconselhariam uma comparação nos termos propostos neste trabalho ${ }^{26}$.

A crítica a propostas de relativismo absoluto na sociologia da ciência, abordadas na seção anterior, consiste em fator suficiente para recomendar abordagens comparativas entre as análises de Merton e a dos autores que defendem perspectivas relativistas e construtivistas em sociologia e história da ciência ${ }^{27}$. Mas, ainda que não seja possível o diálogo em torno de questões substantivas das teorias científicas, os fundamentos da sociologia da ciência, em quaisquer das perspectivas mencionadas, não autorizam uma dissociação entre o conhecimento e os atores sociais que participam de sua produção.

O breve exame de A Estrutura das Revoluções Científicas, de Thomas Kuhn, precursora da análise sociológica adotada pelas perspectivas relativistas do conhecimento, reforça a pertinência do diálogo proposto. Se lembrarmos a acepção mais forte do conceito de paradigma, vê-se que é praticamente impossível dissociar conhecimento científico e comunidade científica. Como se sabe, a comunidade é constituída por aqueles que aderem ao paradigma, ou seja, a uma certa tradição de fazer ciência (cf. Hochman, 1993:5-8).

A semelhança entre a comunidade científica em Kuhn e em Merton dispensa maiores comentários, uma vez que é evidente em ambos os autores a importância atribuída a normas e valores compartilhados como explicação para a prática da ciência. A afinidade entre as perspectivas pode ser inclusive explicada por influências intelectuais comuns, o que é enfatizado por Merton em artigo sobre a constituição da sociologia da ciência (Merton, 1977:3-14). Uma importante diferença consiste, no entanto, na atribuição de um caráter muito mais autônomo à comunidade científica na obra kuhniana. A necessidade de uma amplia-

26 Este é o principal argumento de $\mathrm{H}$. Collins em sua resposta à crítica dirigida por Thomas Gieryn aos programas relativista e construtivista da ciência. Segundo Collins, a retomada da sociologia da ciência de Robert Merton, proposta por Gieryn, só faria sentido para seus propósitos de pesquisa, se a especificidade da ciência diante de outras instituições produtoras de cultura implicasse em alguma conseqüência de natureza epistemológica.

27 Este é o principal tema do artigo anteriormente citado de Gieryn (1982). Ver também as respostas dos autores criticados e a réplica de Guieryn no mesmo número da Social Studies of Science. 
ção de enfoque de $A$ Estrutura das Revoluções Científicas é reconhecida inclusive pelo autor em seu posfácio de 1969, em que defende uma contextualização sociocultural mais ampla do desenvolvimento da ciência.

Deixando de lado o tema das influências, importa observar que as perspectivas que vêem a ciência, à semelhança de outros tipos de conhecimento, como um conjunto de crenças socialmente compartilhadas não podem ignorar as diferentes interpretações sociológicas a respeito da instituição das crenças sociais. Se conhecimento "é tudo aquilo que os homens tomam por conhecimento" (Bloor, 1976:2-3), é crucial investigar as bases sociais de elaboração e validação desse conhecimento. Em suma, opor conhecimento e comunidade científica não parece ser uma posição coerente para os que defendem a análise sociológica da atividade científica.

O que se torna imperioso é uma melhor qualificação da natureza social do conhecimento científico e das práticas interativas dos cientistas. Ao longo deste texto, várias indicações permitem afirmar a possibilidade de estudos comparativos entre a análise mertoniana da busca de prioridade, por exemplo, e perspectivas como as de Pierre Bourdieu (1975) sobre crédito científico e capital simbólico e as de Bruno Latour (1983) sobre o ciclo de credibilidade ${ }^{28}$, entre outras. A crítica usual à obra de Merton especialmente à suposta caracterização da ciência enquanto atividade social pautada por normas consensuais que orientam a ação de cientistas "desinteressados" - cria obstáculos a um diálogo que poderia se revelar enriquecedor. Refiro-me, especialmente, à já mencionada ambivalência no comportamento dos cientistas, que poderia contribuir para uma visão menos reducionista de seus interesses.

Um exame da produção sociológica mais recente sobre o tema revela o predomínio de representações da atividade científica associadas a metáforas como mercado, investidor e capital (cf. Knorr-Cetina, 1991; Hochman,1993). Como se sugeriu no início deste trabalho, acredita-se que um retorno à agenda de pesquisa de Robert Merton pode favorecer uma construção alternativa às que, ao associarem o cientista ao homo economicus da economia clássica, reproduzem a visão simplista de um ser absolutamente racional e maximizador ${ }^{29}$.

28 Para uma crítica às perspectivas dos dois últimos autores, ver Hochman (1993).

29 É interessante, aqui, retomar a crítica de Merton às teorias que atribuíam primazia aos interesses. Segundo o autor "a voga ocasional das teorias do interesse", porque oferecem uma interpretação supostamente adequada é, em si mesma, um problema de Wissenssociologie que merece maior estudo. Variedades particulares encontram-se em algumas das inferências tiradas do postulado do homem econômico, da "teoria da conspiração" em ciência política, da excessiva ampliação dos conceitos de racionalização e propaganda em psicologia (...) A suposição comum a essas diversas verses é a noção hobesiana do egoísmo como força motora da conduta (Merton, 1970:598). 
A crítica aos modelos teóricos que se pautam pela noção da existência de um mercado científico está também presente, numa perspectiva radicalmente distinta da que inferimos da análise da obra de Merton, em estudos como os de Karin Knorr-Cetina $(1981,1982 a, 1982 b, 1983)$. A referência à obra dessa autora tem interesse para o exame de uma última questão relevante na tentativa de trazer ao debate os temas presentes na obra mertoniana. Trata-se do plano de análise que, do ponto de vista das propostas construtivistas, deve deslocar-se do contexto ou da estrutura social para o locus de construção dos fatos e teorias científicas - o laboratório ${ }^{30}$.

Abordagens macrossociológicas estão presentes em toda uma tradição sociológica de pensar a ciência. Em Marx, Durkheim, Mannheim, Merton, apenas para citar as principais referências, o foco da análise consiste em interrogar sobre as bases existenciais do conhecimento humano. O que a crítica dos construtivistas vem apontando é a dificuldade de tais abordagens precisarem como e através de quais mecanismos os fatores sociais participam na construção de fatos científicos particulares (Knorr Cetina, 1982b).

De fato, aqui estamos diante de problemas de outra natureza e que justificam mudanças no plano de análise. Se se adotar a perspectiva de relacionar as diferenças nos planos macro e microssociológicos às distinções no âmbito das questões constitutivas de cada abordagem, tal como sugere a crítica de KnorrCetina, pode-se reconhecer a validade das alternativas colocadas ${ }^{31}$.

Há um problema nesta conclusão. Podemos considerar, seguindo aquela linha de raciocínio, que o papel das abordagens macrossociológicas já estaria cumprido, uma vez que a defesa da natureza social do conhecimento científico é um pressuposto do qual partiriam os construtivistas. Sem pretender realizar uma crítica dessas abordagens, o que transcenderia os objetivos deste trabalho, gostaria de acentuar a atualidade dos temas presentes nas perspectivas macrossociológicas do conhecimento - questões relativas a ideologias, valores, políticas estatais, carreiras científicas, entre outras, são de difícil tratamento pelas abordagens que propõem a construção contingente dos fatos e teorias científicas no âmbito do laboratório.

Quanto à sociologia da ciência de Merton, as breves indicações apresentadas neste trabalho permitem apontar duas questões da maior relevância: a ambivalência no comportamento dos cientistas e a natureza histórica da crença no valor do conhecimento científico. Longe de se constituir em instituição objetiva-

30 Além de Knorr-Cetina, outros autores poderiam ser citados entre os que defendem os estudos de laboratório. Uma referência central é Bruno Latour. Ver a respeito Latour $(1979 ; 1983 ; 1987)$.

31 Os problemas da sociologia da ciência vistos à luz da clássica oposição das ciências sociais entre perspectivas macro e micro são enfatizados no artigo de Hochman (1993). 
mente definida e cristalizada, a ciência é para Merton um empreendimento humano em que a institucionalização e crença social no seu valor não estão assegurados. Retomando o argumento de Max Weber, Merton considera o valor da ciência como um produto de determinadas culturas - o que realça a importância de se relacionar o conhecimento científico com a institucionalização de crenças que orientam a vida social no mundo contemporâneo. Este tema tão freqüente nos estudos do autor pouca atenção vem merecendo nas análises atuais sobre a atividade científica ${ }^{32}$. Aproximar os estudos em sociologia da ciência dos grandes temas da teoria sociológica, situando-os no debate sobre a agência humana, consiste na contribuição mais relevante de um retorno à agenda de pesquisa de Robert Merton.

32 Uma proposta que acentua o papel da ciência contemporânea na conformação de um espaço público é apresentada por Manuel Palácios (1992). O autor recorre à abordagem de Bruno Latour para indicar a possibilidade de produção de consenso através da constituição de redes envolvendo os vários atores que participariam da construção dos fatos científicos, inclusive os relativos à dinâmica social (discursos dos direitos, entre outros). O problema está na abordagem da explicação sociológica em Latour. Segundo este autor, interesses, valores, ideologias não teriam pertinência explicativa. A proposta é deixar que "os atores se definam entre si", sem que o observador recorra a categorias sociológicas prévias. Ver a respeito Latour (1987). 


\title{
Programa Forte da Sociologia do Conhecimento e o Princípio da Causalidade
}

\author{
Manuel Palácios
}

$\mathrm{E}$ ste ensaio atende a um duplo objetivo. Primeiro, apresentar o Programa Forte da sociologia do conhecimento, tal como foi formulado pela Escola de Edimburgo, através de obras publicadas na década de 1970 e início dos anos 80 . Segundo, mantendo-se nos limites de uma exposição do Programa Forte, proporcionar uma discussão um pouco mais detalhada sobre o princípio da causalidade na sociologia do conhecimento científico ${ }^{1}$.

As controvérsias geradas pelo trabalho dos sociólogos de Edimburgo persistem ocupando uma parte significativa dos debates contemporâneos da sociologia da ciência. No entanto, outras abordagens teóricas, ainda que em princípio associadas ao sentido geral do Programa Forte, vieram se desenvolvendo com inspiração diversa do trabalho da Escola de Edimburgo. Um exemplo são as investigações da atividade científica de caráter etnográfico, que contribuíram para o desenvolvimento de temas contidos no âmbito do Programa Forte, mas dificilmente seriam compativeis com alguns de seus princípios originais. Do mesmo modo, os estudos mais recentes, inspirados na teoria das redes, guardam uma relação ambígua com o Programa Forte ${ }^{2}$.

1 A denominação "Escola de Edimburgo" terminou por se consagrar na literatura, reconhecendo a singularidade da abordagem desenvolvida por alguns sociólogos da Unidade de Estudos da Ciência da Universidade de Edimburgo, com ênfase particular na contribuição teórica de Barry Barnes e David Bloor. Das obras que demarcam a perspectiva teórica da Escola, merecem destaque especial: Bloor, 1976 e 1983; Barnes, 1982. Os argumentos desenvolvidos neste ensaio, com o objetivo de expor as linhas gerais do Programa Forte, têm como base, em grande medida, estas três obras.

2 Para uma abordagem construtivista da ciência, ver: Knorr-Cetina, 1981. A elaboração teórica mais desenvolvida, segundo o paradigma ator/rede, encontra-se em Latour, 1987. 
O ensaio foi organizado em quatro seções. Na primeira, apresentam-se as características gerais do Programa Forte, assinalando os seus vínculos com uma tradição de investigação sociológica do conhecimento que inclui Durkheim e Mannheim. Na segunda seção, expuseram-se as objeções de alguns críticos à pretensão de estender os métodos e teorias da sociologia do conhecimento à análise da ciência. Nesta seção, procuram-se enfatizar argumentos derivados da ciência contemporânea da cognição. Na terceira parte, analisa-se a teoria dos jogos de linguagem - desenvolvida pelos sociólogos de Edimburgo com base na contribuição de Wittgenstein. Por fim, na última seção, apresentam-se as propostas teóricas que associam interesses sociais aos processos de formação de crenças e produção de conhecimento.

\section{O PROGRAMA FORTE DA SOCIOLOGIA DO CONHECIMENTO E O PRIN- CÍPIO DA CAUSALIDADE}

A proposição de que há uma relação a ser investigada entre conhecimento científico e o contexto social no interior do qual é produzido encontra-se na origem da sociologia da ciência. As primeiras observações nesta direção datam da virada do século. Pode-se, portanto, legitimamente perguntar os motivos que justificariam a pretensão de se formular um "programa forte" para a sociologia do conhecimento, supostamente mais audacioso e de alcance mais largo dos que os esforços até então empreendidos. Ainda mais quando se tem em vista o fato de que uma boa parte da audácia do programa residiria na tentativa de devassar o território da ciência com os instrumentos analíticos da sociologia do conhecimento.

Uma resposta satisfatória a esta pergunta levaria a investigar duas trajetórias: a sociologia do conhecimento que se desenvolve orientada para o entendimento da cultura, das crenças compartilhadas pelos membros de uma comunidade ou um grupo social, incluindo-se neste rol o tema clássico das ideologias e a investigação antropológica das crenças das sociedades primitivas, e, de outro lado, os estudos sobre a ciência, em particular a atividade científica institucionalizada das sociedades modernas.

Não seria abusivo afirmar que a tendência dominante, durante muito tempo, foi o confinamento da sociologia do conhecimento ao território das ideologias e das crenças do homem comum, conferindo um estatuto particular ao conhecimento científico, supostamente impermeável aos métodos e teorias dos sociólogos. Os estudos sobre a ciência orientavam-se para a investigação histórica das descobertas científicas e a análise das instituições contemporâneas que dão suporte e continuidade ao trabalho dos cientistas. No primeiro caso, a análise histórica contribuía para explicar o nascimento de uma nova teoria ou o descré- 
dito de antigas disciplinas, estabelecendo nexos entre os processos sociais e as inovações científicas. Contudo, as relações estabelecidas permaneciam restritas à elucidação do que se convencionou chamar "contexto da descoberta". A verdadeira história do conhecimento científico transcenderia as circunstâncias contingentes dos cientistas singulares. Para além dos fatos que informam a atividade cotidiana, a trajetória da ciência obedeceria a uma lógica própria, ditada pela natureza especial do conhecimento científico.

Desta perspectiva, a análise das instituições científicas contemporâneas não poderia deixar de se pautar pela lógica atribuída ao processo de desenvolvimento científico. Se a ciência obedece a suas próprias determinações, o que importa investigar é a funcionalidade das instituições existentes para o livre curso do progresso científico. Constitui-se uma sociologia da ciência que não tem propriamente como objeto o conhecimento científico.

A partir da década de 1970, a sociologia da ciência sofreu um duplo processo de mudança. De um lado, veio a se consolidar como uma área de especialização reconhecida, atraindo um número significativo de novos pesquisadores. De outro, assistiu à constituição de novas abordagens, rompendo-se o predomínio da perspectiva funcionalista neste campo de estudos sociológicos ${ }^{3}$.

$O$ processo de institucionalização da sociologia da ciência no universo acadêmico trouxe consigo duas tendências: a ampliação dos limites até então fixados para a investigação sociológica da atividade científica, ao mesmo tempo que estimulou um esforço de demarcação teórica e metodológica frente às outras disciplinas envolvidas com o estudo do conhecimento científico.

A tradição funcionalista havia implicitamente estabelecido uma divisão de trabalho com a filosofia da ciência. Aos sociólogos caberiam os estudos sobre as instituições da ciência moderna e a investigação histórica das inovações científicas, com a perspectiva de se identificarem as determinações sociais atuantes nos diversos contextos relevantes para a história da ciência. Mantinha-se, no entanto, o monopólio filosófico sobre os estudos relacionados com o conteúdo do conhecimento científico. A sociologia investigava o contexto de uma descoberta, mas se deteria, impotente, diante das questões - especificamente filosóficas - relacionadas com o conteúdo daquela descoberta.

A ruptura que se estabelece durante a década de 1970 contesta os limites estabelecidos, propondo como objeto legítimo de investigação sociológica o conhecimento científico enquanto tal. O sociólogo deve investigar o conhecimento

3 Segundo Barnes, por esta época, a sociologia da ciência nos Estados Unidos começa a se concentrar no estudo das especialidades científicas. Na Inglaterra e no continente europeu, torna-se pela primeira vez uma área de estudos reconhecida (Barnes, 1982:14). 
científico do mesmo modo que formula e desenvolve hipóteses para explicar as origens sociais das ideologias políticas ou as raízes das crenças religiosas. Neste movimento, são revisitados os clássicos da sociologia do conhecimento e procura-se estender as suas indagações e métodos à análise da ciência.

O Programa Forte da sociologia do conhecimento representa uma das tentativas de formalização desta ruptura com a tradição pretérita da sociologia da ciência e de recuperação dos clássicos da sociologia do conhecimento para a análise da ciência. Neste aspecto, Durkheim e Mannheim são as duas referências mais importantes para a formulação original do programa, apresentado de modo sistematizado por David Bloor, em Knowledge and Social Imagery, publicado em 1976.

Ultrapassaria os limites deste artigo uma análise mais exaustiva da influência de Durkheim e Mannheim na obra dos sociólogos de Edimburgo, além do fato de esta influência não ser uniforme entre os integrantes do grupo ${ }^{4}$. Ao longo da exposição, acredito tornar-se patente a incorporação, decerto inovadora, de muitas idéias cuja formulação exemplar se encontra nesses dois autores. Apenas com o intuito de situar alguns elementos mais significativos desta influência, cabem duas breves observações.

As remissões à obra de Durkheim são bastante freqüentes no trabalho de David Bloor. Porém, uma noção é particularmente relevante: a concepção durkheimiana de correspondência entre ordem cognitiva e ordem social. Em Formas Elementares da Vida Religiosa, Durkheim concebe a religiăo como expressão transfigurada da sociedade, assumindo a forma de um sistema de crenças que solidariza o indivíduo com a coletividade da qual faz parte. As crenças religiosas derivariam sua força moral do fato de exprimirem - de forma não explícita - os fundamentos de uma determinada ordem social. Deste modo, a ruptura da ordem cognitiva - que se expressa nas sociedades primitivas pela religião - representaria a própria dissolução da vida coletiva, dependente para sua reprodução de consenso quanto à legitimidade de seus fundamentos. Bloor sugere que a ciência desempenharia na sociedade moderna um papel semelhante ao das religiões: ela também constituiria uma representação coletiva do mundo em que vivemos, e, por este motivo, também tenderia a ser protegida com a aura do sagrado. Daí as resistências tão comuns à investigação sociológica do conhecimento científico. Evidentemente, a importância da hipótese durkheimiana de correspondência entre ordem cognitiva e ordem social ultrapassa as consideraçóes acerca das objeções ao Programa Forte. Aplicada à cultura científica do mundo contemporâneo, constitui um argumento favorável à perspectiva de se investigar o conhecimento com o objetivo de nele identificar a

4 Na obra de Barry Barnes, a influência de Durkheim e Mannheim é seguramente menos visível que na obra de Bloor. 
sua tessitura social. E, talvez ainda mais importante, contribui para desfazer a imagem corrente do conhecimento científico como um "produto", sugerindo a fecundidade de uma abordagem que considere a ciência como uma atividade cujo objeto real é a sociedade ${ }^{5}$.

A influência de Mannheim é menos explícita, mas talvez seja mais difusa e relevante que a do próprio Durkheim. Knowledge and Social Imagery poderia, sem exageros retóricos, ser qualificada como uma obra de inspiração mannheimiana ${ }^{6}$. De fato, a tese central do livro sustenta a correspondência entre imagens simplificadas da sociedade - ideologias - e teorias do conhecimento, inspirando-se explicitamente na famosa análise de Mannheim sobre o pensamento conservador. Além das referências diretas, a perspectiva de associação entre padrões de atividade que caracterizam o comportamento de um grupo social e as representações que este grupo produz de si mesmo e da sociedade inclusiva - tema central da sociologia do conhecimento de Mannheim constitui uma das marcas do Programa Forte.

Essas obsenvações não devem conduzir o leitor à crença de que o Programa Forte apenas estende ao território "sagrado" da ciência métodos e teorias da sociologia do conhecimento da primeira metade deste século. Em parte, porque esta operação nada tem de simples e contrasta com muitos dos supostos da obra de Mannheim e Durkheim. Mas, principalmente por conta da relação inovadora que os novos sociólogos mantêm com esta herança. As formulações teóricas mais elaboradas no interior do Programa Forte têm por referência comum a obra de Wittgenstein, que proporciona as bases para uma incorporação seletiva da tradição pretérita da sociologia do conhecimento. Além do papel pioneiro desempenhado pela obra de Thomas Kuhn, ponto de passagem obrigatório no caminho que conduz à semântica finitista de Wittgenstein e, desta, para uma teoria sociológica do conhecimento científico ${ }^{7}$.

De fato, a plena incorporação da teoria do conhecimento de Wittgenstein ocorre em momento posterior à publicação de Knowledge and Social Imagery. Daí serem poucas e muito específicas as referências a Wittgenstein nesta obra. No entanto, os princípios metodológicos do Programa Forte, defendidos ao longo do livro, não guardam descontinuidade com o desenvolvimento posterior da teoria ${ }^{8}$.

5 No livro que dedica à obra de Kuhn, Barnes, parafraseando Durkheim, afirma: "Pode-se dizer que os textos científicos codificam mensagens sobre relações sociais em proposições sobre a natureza" (Barnes, 1982:21).

6 Após a apresentação dos princípios metodológicos que deveriam demarcar o Programa Forte, Bloor afirma que esses princípios representavam "um amálgama dos traços mais otimistas" das obras de "Durkheim, Mannheim e Znaniecki". Bloor refere-se, neste caso, especificamente a Regras do Método Sociológico, de Durkheim, e Ideologia e Utopia, de Mannheim.

7 No livro sobre a obra de Thomas Kuhn, Barnes analisa as afinidades entre o pensamento de Kuhn e a perspectiva de Wittgenstein sobre os processos cognitivos (Barnes, 1982).

8 As referências a Wittgenstein em Knowledge and Social Imagery são poucas e restritas à interpretação da matemática. 
Os quatro princípios enunciados por Bloor demandam da sociologia do conhecimento o compromisso com a máxima generalidade: as teorias devem assumir a perspectiva causal comum a todo o empreendimento cientíico, ainda que se reconheça a participação de causas não-sociais nos processos cognitivos (princípio da causalidade). Devem ser imparciais, assumindo como objeto de explicação tanto o que se acredita verdadeiro, quanto o que se reconhece como falso, racional ou irracional (princípio da imparcialidade); devem ser simétricas, pois os padrões de explicação não devem diferir entre si, quando se trata do erro ou do acerto (princípio da simetria); e por fim, toda teoria deve ser reflexiva, passível de aplicação à própria sociologia (princípio da reflexidade) ${ }^{9}$.

Desses princípios, a defesa de um padrão de explicação causal distingue a orientação da Escola de Edimburgo de outras abordagens teóricas, atualmente influentes. As pesquisas de orientação etnometodológica dificilmente se identificam com a busca de explicações causais. Diversamente, o princípio da simetria, entendido como uma exigência de tratamento analítico uniforme de todos os tipos de discurso, certamente incluiria um leque mais diversificado de orientações teóricas.

Alguns autores - principalmente os críticos de qualquer sociologia do conhecimento científico - incluem diversas perspectivas teóricas sob a rubrica do Programa Forte. Em outros contextos, o Programa Forte mantém-se nitidamente identificado com a produção de David Bloor, Barry Barnes e outros autores próximos. De fato, para muitos críticos da sociologia do conhecimento científico importam pouco as diferenças e os debates entre os seus praticantes ${ }^{10}$.

No entanto, a maior parte dos adversários da sociologia da ciência contemporânea concentra as suas objeções no princípio da causalidade. As razões são evidentes: disciplinas que tradicionalmente investigam a cognição humana, rejeitando a relevância de variáveis sociais para a determinação do conteúdo das teorias científicas, identificam em uma sociologia de perspectiva causal um adversário. Afinal, adotam o mesmo "idioma causal" que supostamente caracteriza todo empreendimento científico.

Na próxima seção, apresentamos as principais objeções dirigidas ao Programa Forte da sociologia da ciência por alguns de seus adversários.

9 Bloor, 1976, cap.1.

10 Peter Slezak, autor de um ensaio crítico da sociologia do conhecimento científico, afirma em sua resposta aos artigos que pretenderam refutá-lo: "(Os seus autores) corretamente observaram que não fui capaz de distinguir nitidamente as várias escolas de pensamento existentes (...) Concedo prontamente que não fui suficientemente atencioso para delinear com exatidão os cismas entre os seguidores desta nova fé" (Slezak, 1989:671). 


\section{MODELO CAUSAL E MODELO TELEOLÓGICO}

A oposição entre o "modelo causal" defendido pelo Programa Forte e o "modelo teleológico", característico de algumas abordagens da ciência, contribui para especificar a orientação da Escola de Edimburgo, assim como precisar os pontos centrais da controvérsia com os críticos da sociologia do conhecimento científico.

De modo geral, o modelo que se opõe à perspectiva causal defende a possibilidade e a validade de uma reconstrução racional da história da ciência, que se define como um relato que prescinde de toda referência contextualizadora. Este relato pode não coincidir com a história empírica e suas inúmeras contingências, mas seria capaz de dar conta do desenvolvimento do conhecimento científico enquanto tal. Desta perspectiva, o que realmente tem importância é explicar a sucessão de teorias como o resultado de opções racionais dos cientistas por aquelas alternativas que no curso das controvérsias mostraram-se mais adequadas empiricamente. A condição para que se efetue este tipo de ordenamento é o abandono de todo evento que perturbe a linha pretendida de evolução da ciência, atribuindo a causas extracientíficas (sociais e políticas, por exemplo) eventuais desvios. Trata-se de um modelo teleológico de explicação da trajetória da ciência, em que o passado transforma-se numa antecipação do atual "estado das artes"11.

Este tipo de reconstrução da trajetória da ciência ofende qualquer método reconhecido de pesquisa histórica e só encontra receptividade por conta do objeto privilegiado de sua investigação: o conhecimento científico. Um dos méritos da obra de Thomas Kuhn situa-se precisamente na adoção de uma metodologia de pesquisa histórica que minimamente respeitasse a cronologia dos acontecimentos ${ }^{12}$.

Contudo, à margem das questões historiográficas e de algumas controvérsias filosóficas, o modelo teleológico encontra receptividade entre pesquisadores contemporâneos da cognição humana. Trata-se, em verdade, de um outro "programa forte", de orientação empírica e "naturalista", reunindo especialistas de di-

11 Em Knowledge and Social Imagery, Bloor expõe o modelo teleológico, recorrendo à obra de Lakatos, com sua noção de uma "história interna" da ciência, auto-suciente e autônoma (Bloor, 1976:5-10).

12 Os primeiros trabalhos de Kyhn sobre a história da termodinâmica, datados da década de 1950, estabelecem as bases de um método de investigação da história da ciência, livre dos anacronismos e inconsistências comumente encontrados neste tipo de literatura. Dentre os princípios de método que o pesquisador deveria respeitar, cabe ressaltar a necessidade de não se violar a cronologia dos acontecimentos, fazendo com que as causas sempre precedem os efeitos, o que significa, por exemplo, não analisar os conceitos empregados por um cientista do passado, recorrendo a noções e teorias que não faziam parte de seu universo intelectual, simplesmente porque surgiram depois (Barnes, 1982:2-3). 
versas áreas do conhecimento: psicologia cognitiva, inteligência artificial, neurociências e lingüística. Recentemente, a controvérsia deu lugar à publicação de uma série de artigos na revista Social Studies of Science ${ }^{13}$.

$\mathrm{Na}$ origem do debate, encontra-se um artigo de Peter Slezak, que pretendia refutar o Programa Forte com base nas realizações das ciências da cognição. $\mathrm{O}$ argumento toma como referência empírica o desenvolvimento recente de modelos computacionais de inteligência artificial, que, segundo o autor, são capazes de reproduzir "em laboratório" os processos de descoberta científica, sem que, para tanto, interviesse qualquer variável social ${ }^{14}$. Interessa, aqui expor as principais críticas veiculadas neste e em outros artigos que furticiparam da controvérsia, na medida em que contribuem para determinar o tipo de objeção dirigida ao Programa Forte da sociologia do conhecimento. Esquematicamente, agruparamse essas críticas em três rubricas: a defesa de princípios universais de racionalidade; a denúncia da falácia da causalidade social do conhecimento e finalmente a indeterminação das variáveis sociais no interior do Programa Forte.

13 A edição de Social Studies of Science de novembro de 1989 publicou um ensaio de Peter Slezak Scientific Discovery by Computer as Empirical Refutation of the Strong Programme -, respondido na mesma edição da revista por uma série de seis artigos, incluindo ainda a resposta de Slezak a seus críticos. Em fevereiro de 1991, a revista publica um pequeno artigo de Herbert Simon - Comments on the Symposium on 'Computer Discovery and the Sociology of Scientific Knowledge' -, pesquisador em ciências da cognição, certamente de índole mais moderada, corroborando algumas das observações de Slezak. A controvérsia prosseguiu com um artigo de Robert Nola - Ordinary Human Inference as Refutation of the Strong Programme - , publicado na edição de fevereiro de 1992 da revista, em que o autor reforça a crítica original de Slezak, mobilizando outros argumentos. Este último artigo foi respondido por David Bloor na mesma edição da revista - Ordinary Human Inference as Material for the Sociology of Knowledge. Por ocasião da segunda edição de Knowledge and Social Imagery, de 1991, Bloor inclui um adendo à obra, respondendo às críticas formuladas por Peter Slezak. Nada indica que a controvérsia esteja próxima do fim. Os artigos mencionados encontram-se nas seguintes edições de Social Studies of Science: vol.19, n. 4, novembro de 1989; vol. 21, n.1, fevereiro de 1991; vol. 22, n.1, fevereiro de 1992.

14 Em Knowledge and Social Imagery, David Bloor enfatizou a oposição entre o modelo causal do Programa Forte e o modelo teleológico, então descrito com base em abordagens derivadas da filosofia da ciência: "Não há dúvida que, se o modelo teleológico é verdadeiro, então o programa forte é falso". Slezak sustenta, no entanto, que a pesquisa empírica realizada nos domínios da ciência da cognição viria confirmando a perspectiva teleológica, propondo-se, nestes termos, refutar o Programa Forte. Slezak menciona em particular os resultados alcançados com programas de computador, projetados para deduzir autonomamente leis científicas clássicas a partir de dados empíricos. Um dos programas citados chama-se sugestivamente BACON, o qual teria sido capaz de "redescobrir versões" da lei de Coulomb, da terceira lei de Kepler, da lei de Ohm, entre outras (Slezak, 1989). 


\subsection{Princípios Universais de Racionalidade}

Segundo Slezak, o desenvolvimento recente da pesquisa científica na área da cognição teria operado uma verdadeira revolução no entendimento dos processos cognitivos. Em síntese, conduziria ao reconhecimento de que existem "princípios universais de racionalidade", que constituem os fundamentos reais da cognição. Sustenta, assim, a centralidade dos mecanismos psicológicos para a compreensão da atividade cognitiva humana. Este fato seria particularmente evidente na atividade científica, em que a "racionalidade" desempenharia o principal papel na determinação do conteúdo das teorias, sendo, neste aspecto, irrelevantes os fatores sociais ${ }^{15}$.

Em particular, as pesquisas na área da inteligência artificial teriam desenvolvido modelos heurísticos de aplicação geral, capazes de operar sobre bases de dados de diferentes origens, alcançando resultados surpreendentes quanto à capacidade de extrair conclusões semelhantes às leis científicas ${ }^{16}$. Essas pesquisas viriam corroborar tanto a hipótese de que a descoberta científica pode ser concebida como a solução de um problema, quanto os modelos de análise da mente como "um sistema de processamento da informação e de manipulação de símbolos". Em ambos os casos, a pesquisa reforçaria a noção de que a capacidade humana de inferência encontra-se ancorada nos processos mentais, com escassa ou nenhuma dependência de variáveis sociais.

Avançando na crítica, insistem nos vínculos que o Programa Forte mantém com a tradição behaviorista em psicologia, há muito desacreditada. Do mesmo modo como Skinner teria pretendido reduzir a complexidade do comportamento humano aos padrões de estímulo-resposta, investigados originalmente em ratos de laboratório, a sociologia do conhecimento científico pretenderia reduzir o complexo processo da cognição à intervenção de causas externas, sociais, negligenciando o papel desempenhado pelos processos mentais.

15 Comentando a inutilidade de se procurar identificar nos programas de computador traços de "contaminação social" - a variedade de leis científicas que esses programas são capazes de "redescobrir" tornaria inútil este esforço - Slezak conclui: "A possibilidade de que todas estas descobertas tenham algumas características culturais em comum, do tipo requerido pelo programa sociológico, é menos plausível que a alternativa de que tenham em comum certos princípios universais de racionalidade, concebidos como fatos essenciais da cognição humana" (Slezak, 1989:574).

16 "[BACON.3] utiliza um conjunto de regras heurísticas limitado e simples para cumprir uma grande variedade de tarefas. Essas regras detectam regularidades e tendências nos dados, e conduzem à formulação de hipóteses e à definição de termos teóricos. BACON.3 representa dados em variados níveis de descrição, onde o mais baixo corresponde ao diretamente observado e o mais elevado corresponde a hipóteses que explicam tudo até ento observado. $O$ sistema pode também realizar e relatar experimentos múltiplos, unificar hipóteses com condições idênticas, ignorar diferenças entre conceitos semelhantes, e descobrir e ignorar variáveis irrelevantes" (Langley et al., apud Slezak, 1989:564). 


\subsection{Falácia da Causalidade}

Decerto, os críticos não podem desconhecer o número crescente de estudos empíricos sobre a história e a produção contemporânea da ciência. Acreditam, porém, que a pesquisa sociológica está muito distante da comprovação do princípio da causalidade proposto pelo Programa Forte. Neste aspecto, algumas de suas observações merecem registro.

Primeiro, assinalam que a descrição detalhada das circunstâncias em que ocorreu uma descoberta científica não constitui em si mesma uma demonstração de nexo causal entre o "contexto social" e o conteúdo das teorias. Ainda que, em alguns casos, seja possível demonstrar a eventual utilidade de uma teoria para a promoção de determinados interesses sociais, esta constatação em nada contribuiria para demonstrar que esses interesses determinem em qualquer grau o conteúdo das teorias.

$O$ argumento de fundo sobre o qual repousa esse tipo de afirmação consiste na distinção entre a descoberta científica, considerada um fato em si mesma, e os processos através dos quais ela vem a ser reconhecida por uma comunidade. Para esses críticos, investigar como uma descoberta é feita não é o mesmo que investigar o seu reconhecimento público. Com isto, pretendem separar os processos mentais, tidos como os determinantes essenciais de uma descoberta, e os sociais, que incidem sobre o uso e a apreciação pública da inovação científica ${ }^{17}$. Em segundo lugar, os estudos empíricos não teriam como distinguir simples "coocorrências contingentes" de verdadeiras conexões causais. Uma proposição causal genuína não perde plausibilidade quando confrontada com hipóteses contrafactuais: não ocorrendo a causa, espera-se que o efeito pretendido não se realize; ou, dada uma causa diferente, supostamente deveria se seguir um efeito também diverso. Uma proposição contrafactual seria ilustrada por uma indagação do seguinte tipo, enunciada por Slezak: tendo sido outras as circunstâncias sociais relevantes, poderia Isaac Newton ter proposto uma lei da gravitação diferente?

Nestes termos, o argumento causal ou se reduz a uma proposição trivial, pois é evidente que nenhuma atividade humana se desenvolve no vazio social, ou transfigura-se em uma simples sugestão de homologia entre um determinado contexto cultural e social e as controvérsias científicas da época. Neste último caso, não chegam a ser estabelecidas autênticas relações causais entre variáveis

17 'É precisamente a questão causal de 'como ocorreram' [as descobertas científicas] que as teorias mental/cognitivas poderão explicar. É perfeitamente correto, senão trivial, dizer que a psicologia não pode explicar" a atribuição de status (Slezak, 1989:580). 
sociais e conteúdo das teorias. No máximo, a sugestão de uma correlação, em que "o espírito da época" - conceito um tanto discutível - determinaria tanto o "contexto social" quanto o caráter das controvérsias científicas ${ }^{18}$.

\subsection{Indeterminação das Variáveis Sociais}

Um último argumento merece um registro especial. Os críticos mencionados denunciam a existência de duas diferentes representações do social no interior do Programa Forte. A primeira dessas representações estaria comprometida com o princípio da causalidade e teria como conseqüência a caracterização ambígua e imprecisa das variáveis sociais que supostamente têm papel determinante do conteúdo das teorias. Referem-se a análises que procuram estabelecer relações entre "contexto social" e conhecimento científico. Neste caso, "contexto" significa o recurso amplo às circunstâncias sociais e históricas que constituem o ambiente no interior do qual se desenvolve a atividade científica. O segundo padrão de representação é associado à utilização do conceito de interesse, como variável social relevante. Neste caso, afirmam os críticos, a teoria torna-se mais plausivel, mas à custa das pretensões originais do Programa Forte. A noção de interesse, utilizada em sentido amplo, incorpora um elenco de motivaçóes que tornaria indeterminada a fronteira entre o social e o psicológico. A menção, por exemplo, ao "interesse" no desenvolvimento técnico e no incremento da capacidade de previsão da ciência enfraqueceria, na visão desses críticos, qualquer postulação forte de causalidade social do conhecimento ${ }^{19}$.

O elenco de questões apresentado nos serve como contraponto para o restante da discussão. A semântica finitista de Wittgenstein e sua teoria dos jogos

18 No prefácio redigido por Rom Harré para The Manufacture of Knowledge, a mesma crítica é formulada, desta feita a partir de dentro da própria sociologia do conhecimento científico: "A idéia de uma relação entre a ordem social de um período e o conteúdo das teorias científicas, popular durante algum tempo, foi recentemente revivida pela Escola de Edimburgo (por exemplo no trabalho recente de Bloor, 1976). Esta é uma tese muito forte, e tem havido sérias objeções a ela. A mais fundamental talvez seja a de que não há um modo de se distinguir se há uma relação causal entre a ordem social e as idéias científicas de uma época, ou se existe uma terceira variável, o 'Zeitgeist', o que quer que isto seja, que gera ambas" (Knorr-Cetina, 1981).

19 "Embora uma teoria do interesse social (...) seja apenas implausível, sugiro que também seja potencialmente trivial. (...) Bem mais plausíveis como 'interesses' causais são os que promovem, nem tanto objetivos pessoais, profissionais ou sociais, mas o interesse no entendimento, na explicação beın-sucedida ou talvez em encontrar a 'verdade'. Shapin os denominou interesses 'técnico-instrumentais' em 'previsão e controle'. Formulada deste modo, acredito que a 'teoria do interesse' esteja a salvo de qualquer crítica, mas esta é uma vitória de Pirro para o sociólogo do conhecimento. A teoria perdeu todo o seu conteúdo radical original (...)" (Slezak, 1989:595). 
de linguagem - tema da próxima seção - tem como objetivo declarado desacreditar "princípios universais de racionalidade". Por fim, os esforços de teorização da Escola de Edimburgo, concentrados em particular na análise do papel dos interesses sociais nos processos cognitivos, pretendem especificamente demonstrar a inadequação de toda explicação de base psicológica do conhecimento.

\section{O PROGRAMA FORTE E A TEORIA DOS JOGOS DE LINGUAGEM DE WITTGENSTEIN}

Mannheim e Durkheim são as duas referências mais significativas de Knowledge and Social Imagery. Certamente, a influência desses dois clássicos da sociologia do conhecimento permanece nas obras do início da década de 1980. No entanto, a presença do pensamento de Wittgenstein cresce no período, à medida que a necessidade de fundamentos epistemológicos mais elaborados vai se impondo. Da obra da segunda fase de Wittgenstein, Bloor desenvolve uma teoria do conhecimento afirmativa do caráter eminentemente social dos processos cognitivos. Por sua vez, Barry Barnes analisa as afinidades da obra de Kuhn com o pensamento de Wittgenstein ${ }^{20}$.

\subsection{A Teoria dos Jogos de Linguagem de Wittgenstein}

A teoria dos jogos de linguagem de Wittgenstein, apoiada em uma semântica finitista, conduz à afirmação do caráter convencional de todo conhecimento. Porém, não são decisões arbitrárias dos indivíduos que determinam o que conta como convencional. As convenções lingüisticas estão ancoradas em padrões de atividade coletiva - "formas de vida", segundo Wittgenstein. Esta abordagem dos problemas da cognição conduz à rejeição de toda análise do conhecimento fundada em um "princípio de racionalidade", concebido como atributo individual, independente das relações sociais.

$\mathrm{O}$ finitismo e a teoria dos jogos de linguagem não respondem, de fato, ao conjunto de indagações que dão vida ao Programa Forte. Contudo, têm um efeito corrosivo sobre as alternativas adversárias e oferecem os fundamentos sobre os quais uma teoria sociológica causal do conhecimento pode ser elaborada, tema reservado à última seção do artigo.

Inicialmente, analisaremos as relações entre significado e uso das palavras, tema que nos conduz à noção de jogos de linguagem. Em seguida, trataremos

20 Bloor, 1983; Barnes, 1982. A exposição do pensamento de Wittgenstein tem como base a interpretação oferecida por esses dois autores. 
das relações entre "formas de vida" - padrões de atividade não-lingüística - e jogos de linguagem. Os dois temas demarcam os contornos do finitismo e permitem estabelecer o caráter convencional do conhecimento. Por fim, discutimos os problemas relativos à aplicação conceitual, enfatizando as duas faces que a questão apresenta: de um lado, os processos de treinamento e a rotinização da linguagem; de outro, a inovação e a transformação dos jogos de linguagem.

\subsection{Uso e Significado}

Que relação devemos fazer entre o significado das palavras e o seu uso na vida cotidiana? Em termos simplificados, podemos formular duas alternativas: ou o significado de uma palavra explica o uso que dela fazemos, ou, inversamente, é o uso que determina o seu significado. No primeiro caso, as palavras, uma vez apreendido o seu significado mediante algum tipo de aprendizado por ostensão ${ }^{21}$, fazem-se associar mentalmente a propriedades, objetos ou situações, o que permitiria posteriormente a sua aplicação em ocasióes novas, mediante o recurso ao registro mental prévio. De acordo com a perspectiva de Wittgenstein, ancorar o significado das palavras em processos mentais de apreensão do mundo externo conduzia a um raciocínio circular inexpressivo. A crítica dirige-se, em particular, a duas teorias que, então, disputavam o tema: a das imagens mentais e a dos atos mentais. Em ambos os casos, a decisão quanto ao uso de uma palavra em uma dada circunstância seria explicada por processos mentais. Para os defensores da teoria das imagens, o procedimento envolvido seria, basicamente, uma comparação entre a imagem registrada no cérebro, correspondente a um conceito, e o que é observado. Para os defensores da teoria adversária, que se apoiava empiricamente na sugestão de que havia pensamento sem a presença de imagens, seria um ato intencional do observador (concentrar a atenção, focalizar) que discriminaria no mundo externo as características ou objetos correspondentes a uma palavra ${ }^{22}$.

21 Aprendizado por ostensão designa uma situação em que os objetos aos quais a palavra se aplica são apontados diretamente por alguém que ensina àquele que aprende. Kuhn oferece-nos um exemplo comum de aprendizado por ostensão em A Estrutura das Revoluçōes Científicas, também citado por Barry Barnes. O pai ensina o filho, durante uma caminhada, a distinguir entre três tipos de aves: gansos, cisnes e patos. A cada oportunidade, aponta para o filho uma ave e a nomeia: este é um ganso, aquele é um pato. O filho, por sua vez, em pouco tempo iniciará seus próprios esforços de aplicação conceitual. Pai, este é um ganso. O pai então confirma a afirmação do filho, ou o corrige: não, este é um cisne, observe o seu pescoço alongado. Não há muita controvérsia quanto ao fato de que esses procedimentos de aprendizado por ostensão caracterizam a iniciação de uma criança no uso competente de uma linguagem (Barnes, 1982).

22 Bloor, 1983, cap. 2. 
Para Wittgenstein, o problema permanecia inalterado, quer se recorrendo a imagens ou a atos mentais. As crianças aprendem o significado das palavras através de exemplos de sua aplicação em situações concretas. Deste modo, acumulam um repertório de exemplos em que uma determinada palavra pode ser usada com referência a um objeto, propriedade ou situação. O problema de saber como se processa, após este aprendizado inicial, o uso das palavras por um indivíduo não se vê facilitado pela substituiçăo da palavra por uma imagem. Assim como a noção de um ato mental - "apontar mentalmente um objeto" - depende de algum ordenamento prévio do que é observado, não podendo ser concebido como uma explicação para o significado das palavras.

A resposta de Wittgenstein é simples: não se pode radicar o significado das palavras em nenhum dos processos mentais assinalados. Recusando as explicações psicológicas então em voga para o problema do significado, Wittgenstein sustenta que o significado de uma palavra se radica exclusivamente no uso. "As experiências mentais que acompanham o uso de um signo são causadas pelo uso deste signo em um sistema particular de linguagem ${ }^{\prime 23}$. O conceito de jogos de linguagem deriva desta percepção original sobre o problema do significado.

Assim, toda investigação sobre o conteúdo de um conceito deve procurar identificar os seus diversos "contextos de uso", o que significa analisar os vários jogos de linguagem de que uma mesma palavra pode participar. Como se sabe, os bons dicionários sempre fazem acompanhar o esforço de definição dos significados atribuídos a uma palavra por uma série de exemplos de aplicação, reconhecidamente exemplares, quando não recorrem a ilustrações.

\subsection{Jogos de Linguagem e Padrões de Atividade}

A remissão do problema do significado das palavras aos padrōes sistemáticos de uso transfere o problema do conteúdo das proposições verbais para a investigação empírica dos jogos de linguagem. Porém, nada foi dito sobre a conformação de padrões sistemáticos de uso e, portanto, de jogos de linguagem. Wittgenstein oferece uma resposta a esta questāo, associando os jogos de linguagem aos padrōes de atividade dos indivíduos. Os jogos de linguagem só se tornariam compreensíveis quando percebidas as suas conexões com "formas de vida".

Deste modo, Wittgenstein ancora o significado das palavras nas atividades práticas desenvolvidas pelos indivíduos no curso de sua existência como membros de uma coletividade. As palavras seriam ferramentas, instrumentos indispensáveis às atividades cotidianas das pessoas. Na medida em que um

23 Wittgenstein apud Bloor, 1983:19. 
martelo é indispensável ao trabalho de um carpinteiro, pode-se dizer o mesmo das palavras que este trabalhador emprega no curso de suas atividades. Um padrão de uso não é, portanto, arbitrário, pois encontra-se integrado a padrões de atividade humana.

Note-se, contudo, que os homens desenvolvem inúmeras atividades, de caráter muito variado. As palavras participam, portanto, de muitos contextos diferentes de uso, cumprindo funções também diversificadas. Deste modo, seria inconsistente com o argumento desenvolvido a pretensão de se formular uma teoria da linguagem que esgotasse em uma única fórmula as relações entre a "palavra" e a "vida" 24 .

\subsection{Finitismo}

Essa argumentação conduz a um tipo de semântica caracterizada como finitismo. O uso determina o significado das palavras a partir das funções que estas desempenham nas atividades coletivas dos indivíduos. O conjunto de situações em que uma palavra é empregada por uma coletividade determina um universo finito de aplicações reconhecidas.

Um corolário do finitismo é que toda aplicação de um conceito envolve um juízo contingente quanto à sua aplicabilidade. Esta é uma decisão do indivíduo, que tem por referência os casos precedentes de aplicação do conceito, através dos quais foi se capacitando ao uso da linguagem. Por sua vez, este repertório de usos reconhecidos constitui um patrimônio coletivo, estabelecendo o consenso necessário à comunicação. Desta dinâmica, que envolve julgamentos individuais e produção de consenso comunitário, resulta um cenário de relativa indeterminação dos possíveis usos de uma palavra. O uso prévio é sempre insuficiente para delimitar as eventuais utilizações futuras de um conceito ${ }^{25}$.

Os jogos de linguagem são, portanto, construções lingüísticas em aberto. Cada inovação implica um acréscimo ou uma mudança não determinada por sua forma verbal pretérita. A aceitação desta proposição implica o descrédito de toda tentativa de explicação das mudanças que ocorrem na esfera do conhecimento como conseqüência de uma lógica de argumentação verbal. Isto não significa, como querem alguns críticos, considerar irrelevantes os argumentos mobi-

24 Bloor, 1983, cap.3.

25 As considerações sobre a aplicação de conceitos podem ser reproduzidas para as teorias científicas. As aplicações de uma teoria não existem antes dos atos concretos de aplicação. Assim como não se podem determinar previamente os possíveis desenvolvimentos de uma teoria ou os limites de sua validade. Barnes cita como exemplo o debate sobre a validade e os limites de aplicação da mecânica clássica (Barnes, 1982:32). 
lizados numa controvérsia. Ao contrário, argumentos constituem o principal material de uma pesquisa sociológica empírica, mas não se pretende atribuir a eles uma força que não possuem: determinarem o resultado da controvérsia.

Para Wittgenstein, "jogos de linguagem são sistemas completos de comunicação humana, não são fragmentos de uma linguagem" (Bloor, 1983:24). São sistemas completos porque referidos a "formas de vida" concretas, atendendo às necessidades dos que delas participam. Assim como a vida, os jogos de linguagem encontram-se envolvidos em processos contínuos de mudança. Porém, o jogo não muda por conta de exigências lógicas ou regras abstratas de aplicação conceitual, mas porque os homens não cessam de inovar.

\subsection{Aplicação Conceitual: rotinização e inovação}

Uma vez radicado o significado das palavras nos padrões de uso e considerados os nexos com as atividades práticas dos indivíduos, permanecem ainda obscuros os procedimentos que vinculam as palavras às coisas.

Para responder a esta questão é necessário prosseguir a análise sobre a formação de conceitos. Bloor recorre à noção de "semelhanças de família", bastante empregada por Wittgenstein, para explorar os procedimentos de classificação, que estão na origem de muitos conceitos. Entre os membros de uma família, há muitas características compartilhadas, ainda que elas não sejam sempre as mesmas para todas as pessoas da família. Mesmo assim, adquire sentido, e, efetivamente, somos capazes de atribuir características comuns aos membros da família. A metáfora serve para ressaltar a noção de que a propriedade comum que aparentemente organizou a classificação, constitui antes de tudo o resultado da classificação, e não a sua causa ${ }^{26}$.

Note-se, porém, que os procedimentos de classificação não operam de modo totalmente arbitrário, sem qualquer tipo de constrangimento. Os julgamentos de semelhança se realizam no interior de jogos de linguagem, que se desenvolvem com base em padrões de atividade não-lingüística. A atribuição de uma propriedade comum a um conjunto de objetos não se realiza com independência do tipo de relação que os homens mantêm com eles. Decerto, nada mais diferente para um observador alienígena que um martelo e um esquadro, mas ambos são ferramentas do cotidiano de um carpinteiro.

26 "Conceitos de semelhança de família são freqüentes na linguagem classificatória da história, especialmente a história da cultura e da arte. Pensemos, por exemplo, como filósofos são agrupados em escolas, ou pinturas, em estilos" (Bloor, 1983:31). 
Bloor concede em sua argumentação o reconhecimento de que nem todos os conceitos têm uma estrutura de semelhança de família. No entanto, mesmo considerando-se a existência de conceitos construídos com base na seleção de uma propriedade comum, mantém-se inalterado o caráter social e convencional da aplicação conceitual. O argumento é simples e é ilustrado com o recurso a exemplos extraídos da história do conhecimento científico ${ }^{27}$. A seleção de propriedades introduz ordem na variedade de relações que podem ser, em princípio, propostas sobre o que é objeto de nossa observação. Porém, trata-se de uma ordem continuamente ameaçada pela complexidade dos fenômenos que se pretende apreender conceitualmente. O que em um momento constitui nítida percepção de propriedades comuns, pode, em seguida, se converter em frouxas semelhanças, sobre as quais tornamo-nos inseguros quanto à existência, de fato, de um atributo unívoco. Em ambos os casos - "semelhanças de família" ou "propriedades comuns" -, os conceitos dependem de convenção.

A crença em uma linguagem derivada diretamente da observação é, neste contexto, abertamente contestada. Assim como a distinção entre uma linguagem teórica, construída segundo princípios hipotético-dedutivos, e a suposta linguagem da observação. A percepção contém um componente social ineliminável.

Decerto, 0 aprendizado se realiza sobre uma base biológica e psicológica comum aos homens. No entanto, a capacidade humana de processar informações e julgar situações depende do estabelecimento de uma ordem cognitiva prévia. Para Wittgenstein, as pessoas aprendem uma linguagem por intermédio de treinamento. O que deve ser entendido em sentido corrente são procedimentos em que uma "autoridade" sanciona o uso correto das palavras. Os procedimentos de socialização, através dos quais um indíviduo torna-se um usuário de uma linguagem, não eliminam o julgamento individual quanto à aplicabilidade de um conceito, nem o papel desempenhado pelo repertório de exemplos de uso do conceito reconhecidos pelo grupo. $O$ uso rotineiro da linguagem torna essas decisões automáticas. A conversa do dia-a-dia recicla, atualiza e rotiniza o emprego corrente da linguagem ${ }^{28}$.

O hábito e a rotina estabelecem as bases da comunicação cotidiana. No entanto, freqüentemente o uso de um conceito afasta-se de um padrão rotineiro, situação em que o caráter convencional do conhecimento torna-se mais evidente. Uma nova aplicação de uma teoria científica implica uma decisão da comunidade sobre a sua validade. $\mathrm{O}$ processo que conduz à aceitação de uma inovação teórica na ciência é semelhante ao que consagra o uso inovador de um conceito em outras áreas da atividade humana. A inovação torna visivel o caráter contingente dos juízos de aplicação con-

27 Bloor cita extensamente a análise de Ludwik Fleck sobre o surgimento do conceito moderno da doeņ̧a que hoje conhecemos como sífilis. O exemplo é muito elucidativo do caráter convencional do conhecimento científico (Bloor, 1983:34-36).

28 Ver a análise sobre treinamento e relações de semelhança em Barnes, 1982:22-27. 
ceitual e os processos que conduzem, ou não, ao seu acatamento coletivo. $O$ que o treinamento e a rotinização ocultam, as decisões inovadoras tendem a ressaltar, trazendo à luz o caráter convencional de todo conhecimento. Convém observar, no entanto, que inovação e rotina, além de não constituírem dados fixos, são interdependentes. O que hoje é uma inovação contestada transforma-se em uso rotineiro consagrado, assim como o que já foi uma rotina inquestionável converte-se em uso inadequado da linguagem. Nenhuma inovação pode contestar sem limites o uso rotineiro dos conceitos. Uma aplicação conceitual não-rotineira supõe a manutenção da ordem congnitiva preexistente em uma extensão tal que permita a continuidade da comunicação. Podem existir contextos sociais em que as possibilidades de inovação sejam muito restritas e as transformações de uso quase imperceptíveis, conformando-se a padrões de vida coletiva estáticos. Mas não é concebível uma situação que cancela a base rotinizada da atividade lingüística. Rotinização e inovação são, por assim dizer, as duas fases do processo constante de mutação dos jogos de linguagem.

Para os adeptos de uma semântica fundada na noção de extensão, a aplicação conceitual não guarda relação com os juízos individuais e formação de consenso. Daí a afinidade do finitismo com uma perspectiva de investigação sociológica do conhecimento. Quando se atribui à palavra uma classe de referência ou extensão, a qual inclui todas as suas possíveis aplicações, afasta-se o conhecimento do terreno instável das transações humanas para o continente habitado exclusivamente por palavras, argumentos, lógica e experimentação. Da perspectiva do finitismo, o conceito de extensão não possui qualquer sentido. $O$ mesmo pode-se dizer da idéia de universais e essências como critérios de aplicação conceitual.

Enfim, o finitismo e a teoria dos jogos de linguagem sustentam o caráter convencional de todo o conhecimento, corroborando a perspectiva de que não há fronteiras rígidas entre os diversos tipos de conhecimento: da religião à ciência, dos sistemas metafísicos ao senso comum, encontramos procedimentos semelhantes de formação de conceitos e a mesma lógica que associa rotinização e inovação nos processos de mudança cultural.

Quando se sustenta o caráter convencional do conhecimento, ainda se corre o risco de uma interpretação equívoca, que contradiz os fundamentos do finitismo. Daí a utilidade de se reproduzir à advertência de Barry Barnes sobre este tema. Não se concebe o conhecimento como um sistema de convençôes "que determina como pensar e como agir". "São nossas decisões e julgamentos que determinam o que vale como convenção e logo o que sustém e desenvolve um contexto convencional". Não se diz que o conteúdo de toda a proposição seja dependente do "contexto teórico", e sim que o significado dos conceitos e das proposições depende de como nos utilizamos dele (Barnes, 1982:30). 
Da perspectiva do Programa Forte, os argumentos expostos escoram sua pretensão de fundar uma teoria sociológica do conhecimento. No entanto, o seu papel até aqui é, antes de tudo, negativo: constitui uma refutação do modelo teleológico e uma resposta a suas críticas.

Mas se a intenção é uma sociologia causal, ainda não se dispõe de uma teoria que explique os atos específicos de uso de conceitos e de aplicação de teorias. Argumentou-se que padrões de uso pretérito não esgotam o problema e foram descartadas explicações com base em "princípios abstratos de racionalidade". As tentativas de teorizaçăo que apresentamos a seguir sugerem que interesses e objetivos sociais devem ser considerados as variáveis que determinam as decisões sobre uso dos conceitos e aplicação das teorias ${ }^{29}$.

\section{INTERESSES E CONHECIMENTO}

Os argumentos alinhados na seção anterior reproduzem o desenvolvimento dado por David Bloor e Barry Barnes ao pensamento de Wittgenstein, com o objetivo de estabelecer os fundamentos de uma teoria social do conhecimento. No entanto, o padrão de explicação causal pretendido pelo Programa Forte permanece um tanto impreciso.

No último capítulo de seu livro dedicado à obra de Thomas Kuhn, Barry Barnes oferece algumas sugestões, especificando o papel dos interesses na análise sociológica do conhecimento. Por sua vez, David Bloor desenvolve uma tipologia dos jogos de linguagem, um exemplo útil de como podem ser associadas "formas de vida" e estratégias preferenciais de aplicação conceitual ${ }^{30}$.

\subsection{Finitismo e Instrumentalismo}

Na obra de Thomas Kuhn, o conceito de anomalia ocupa um lugar de relevo na explicação das revoluções científicas, tal como ele concebia os processos de mudança paradigmática na ciência. A acumulação de resultados não previstos por um paradigma conduziria a um possível cenário de crise, de descrença entre os praticantes de uma disciplina na força do paradigma, criando-se as condições para uma revolução científica ${ }^{31}$.

29 Barnes contrasta a perspectiva de formulação de uma teoria causal com a abordagem etnometodológica, que se abstém de qualquer consideração sobre por que um padrão de uso de uma teoria ou de um conceito foi selecionado (Barnes, 1982: 94-101).

30 Bloor, 1983, cap.7; Barnes, 1982, cap 5.

31 Kuhn, 1970. Ver em particular o capítulo 6: "Anomaly and the Emergence of Scientific Discovery". 
No entanto, o conceito de anomalia tem um estatuto ambíguo no interior da teoria. De um lado, constitui a causa das mudanças paradigmáticas. De outro, a percepção de uma anomalia não pode ser considerada simplesmente como um resultado da atividade experimental. Basta recordar que a ciência normal se desenvolve com base no treinamento do cientista para uma atividade determinada pela adesão a um paradigma. Um experimento que não confirma a expectativa do cientista constitui, em primeiro lugar, um desafio à sua habilidade e inteligência, e não uma ameaça imediata à validade do paradigma compartilhado por uma comunidade científica.

Barnes questiona o papel causal atribuído às anomalias por Kuhn. Em vez de consistirem em explicação razoável da mudança, são as próprias "anomalias" que devem ser explicadas. A decisão de transformar um resultado não esperado em contra-exemplo é um ato que demanda explicação. Esta argumentação é reforçada, em outra parte do texto, pela análise das possíveis estratégias de acomodação teórica aos resultados experimentais, feita com base na obra de Duhem. Não caberia, aqui, expor na íntegra a sua tese. Esquematicamente, Duhem demonstra que sempre é possível introduzir modificações marginais em uma construção teórica de modo que ela venha a se acomodar com a evidência experimental (Barnes, 1982:73-77). A questão, portanto, é explicar as escolhas estratégicas de uma comunidade científica.

A constatação de uma anomalia é uma situação estruturalmente semelhante à afirmação de uma descoberta científica. Em ambos os casos, rompe-se com o uso rotinizado dos conceitos - ou das teorias -, criando-se novos conceitos para ordenar a observação ou aplicando-se a teoria em contextos não usuais. A questão teórica relevante consiste, portanto, em explicar as estratégias de aplicação conceitual, os juízos que se difundem, expressando a preferência de um grupo pela manutenção de um padrão de uso, ou, inversamente, por sua transformação. Justamente porque essas estratégias e preferências não são pré-determinadas por uma lógica conceitual ou por imposições experimentais, devem ser explicadas com base em interesses e objetivos compartilhados.

A perspectiva teórica desenhada por Barnes conduz a uma abordagem instrumental do conhecimento. Não custa lembrar o quanto o instrumentalismo se aproxima da noção original, derivada de Wittgenstein, de que o significado das palavras encontra-se radicado nas funções que elas cumprem no curso de atividades coletivas, orientadas para a realização de fins compartilhados.

Para complementar a percepção do papel dos interesses na determinação de estratégias de aplicação conceitual, deve-se recordar o quanto a comunicação depende de padrões rotineiros de uso. Os interesses que informam o juízo sobre o uso dos conceitos não deslocam o papel desempenhado pela rotina, o hábito e a autoridade. Eles incidem sobre o uso rotineiro da linguagem, constituindo-se em variáveis explicativas dos padrões de mudança na esfera do conhecimento. 
A implicação causal defendida por Barnes não deve ser traduzida por uma relação discreta entre conceitos ou crenças e tipos específicos de interesse. Primeiro, porque o objeto da explicação não é um conceito ou uma crença, mas padrões de aplicação conceitual referidos a jogos de linguagem, a contextos de uso; segundo, porque não há como atribuir a um único tipo de interesse ou objetivo o papel isolado de variável causal relevante. Do mesmo modo como as palavras cumprem funções diferentes em diferentes contextos de uso, são diversos os tipos de interesses e objetivos que podem estar implicados nas decisões de uma coletividade sobre o uso de conceitos e teorias. Algumas situações empíricas podem ressaltar o papel dos interesses e objetivos de uma pequena comunidade científica: desenvolvimento de uma técnica, incremento do poder de previsão de uma teoria, institucionalização da disciplina, atribuição de prestígio aos seus praticantes, e outros tantos. Outras situações podem sugerir a incidência forte de interesses e objetivos de caráter mais amplo: a defesa da ciência contra investidas de adversários, objetivos estatais, interesses de classe, de grupos sociais. Nada obriga a rejeitar, em princípio, a referência a macrossituações.

Para Barnes, finitismo e instrumentalismo são perspectivas complementares. Se a investigação é interrompida, como querem os etnometodólogos, na análise do discurso, não se alcança uma explicação positiva das opções e estratégias discursivas. Para tanto, é preciso ir além: trazer para o primeiro plano da análise as causas das opções e estratégias adotadas em uma situação determinada. De outro ângulo, a perspectiva instrumental é sempre limitada pela adesão a uma semântica fundada na noção de extensão. Neste caso, termina-se por atribuir ao conhecimento o poder de determinar os padrões de atividade humana, quando a relação causal que se procura estabelecer tem o caráter inverso.

Acompanhando o argumento de Barnes, estivemos interessados em determinar o lugar dos interesses na explicação causal dos processos de mudança na esfera do conhecimento. Fizemos menção ao fato de que os interesses atuam sobre o conhecimento pretérito, sobre uma rotina estabelecida. Importa, também, termos alguma percepção de como um padrão de uso rotineiro encontra fundamento social. Algo nesta direção nos oferece David Bloor com sua teoria sistemática dos jogos de linguagem.

\subsection{Formas de Vida e Jogos de Linguagem}

Bloor elabora uma teoria social dos jogos de linguagem, incorporando a sugestão de Wittgenstein sobre o papel desempenhado pelas necessidades humanas na conformação dos jogos de linguagem. Interesses sociais seriam a tradução adequada de necessidades. Em conformidade com a perspectiva de Barnes, Bloor situa nos interesses compartilhados por um grupo social a base sobre a 
qual são estruturados os jogos de linguagem. A investigação sociológica do conhecimento deve, portanto, identificar os interesses que participam na determinação dos padrões de transformação, rivalidade e aceitação dos jogos de linguagem (Bloor, 1983:137).

O êxito desta tradução depende integralmente de uma teoria plausível sobre as relações entre formas de vida, interesses sociais e jogos de linguagem. A análise dos possíveis padrões de resposta à anomalia - inspirada na obra da antropóloga Mary Douglas - conduz à proposição de uma tipologia dos jogos de linguagem e de sua relação com interesses sociais.

A análise de Bloor não se concentra especificamente sobre o conhecimento científico. Anomalias traduzem situações não-familiares, quando um grupo se confronta com eventos inesperados, personagens sociais desconhecidos, ou novos agrupamentos rivais. Em síntese, seriam quatro os possíveis padrões de resposta à anomalia: indiferença, rejeição, acomodação ou oportunismo. Ignora-se o que não corresponde a nossas expectativas ou projeções; excluem-se os casos que não se conformam a nossos conceitos; acomoda-se o potencialmente crítico, recorrendo-se a ajustes e pequenas mudanças em nossas crenças; ou aceitase o imprevisto como uma oportunidade de promover nossos próprios objetivos, e apenas enquanto isto for possível.

As diferentes atitudes frente ao anômalo, ao que não nos é familiar, encontram tradução em diferentes tipos de jogos de linguagem. São, fundamentalmente, estratégias constituintes. O que importa investigar, então, é por que um grupo social adota esta ou aquela: que interesses são eventualmente promovidos por essas estratégias.

Os quatro tipos ideais de jogos de linguagem, sugeridos por Bloor a partir da caracterização das quatro atitudes básicas frente ao anômalo, são postos em correspondência com padrões de organização social. Ainda seguindo os passos de Douglas, Bloor utiliza duas variáveis para definir essas 'formas de vida': padrões de definição das fronteiras de grupo e de estratificação interna do grupo. Uma matriz dois por dois ordena a correspondência hipotética entre tipos de jogos de linguagem e as possíveis combinações das duas variáveis, segundo as categorias alta e baixa.

Temos, assim, quatro 'formas de vida', relacionadas a quatro estratégias frente ao anômalo, segundo o quadro esboçado abaixo (Bloor, 1983:141).

\begin{tabular}{|l|c|c|}
\hline Definição de grupo & Alta & Baixa \\
\hline Estratificação interna & & \\
\hline Alta & Acomodação & Indiferença \\
\hline Baixa & Rejeição & Oportunismo \\
\hline
\end{tabular}

Atitudes básicas frente a situações não-familiares, constituintes de jogos de linguagem. 
A relação causal proposta por Bloor situa-se entre as duas variáveis que determinam formas de vida e as estratégias de aplicação conceitual implícitas nos padrões de resposta ao anômalo.

Um grupo caracterizado por critérios muito rígidos de pertencimento e pequena estruturação interna tenderia, segundo o modelo de Bloor, a desenvolver uma estratégia de rejeição ao que não é familiar. São grupos impermeáveis à inovação, fortemente aderentes à rotina. Os exemplos podem variar desde uma pequena comunidade de cientistas que rejeita toda inovação, até o tipo de cultura desenvolvida por pequenas tribos urbanas. Nesses casos, a ameaça de expulsão do grupo é um importante recurso de controle e prevalece a percepção de que há inimigos por toda parte, exigindo cuidados e vigilância permanentes. Enfim, qualquer anomalia surge como uma ameaça à integridade do grupo.

Bloor associa a preferência por estratégias de acomodação conceitual a grupos com elevada organização e hierarquia interna e acentuada demarcação de suas fronteiras. Uma estrutura burocrática tem um caráter semelhante a este. Constitui uma hipótese de investigação a tendência a se desenvolverem neste contexto padrões de acomodação, em que as inúmeras diferenças e tensões existentes entre subgrupos hierarquizados venham a ser acomodadas com o recurso a construções intelectuais mais elaboradas. À diferença do padrão anterior, em que a ameaça de contaminação pelo impuro constitui um emblema, teríamos neste caso uma acentuada ritualização das relações, acompanhadas de necessárias justificativas. Para Douglas, citada por Bloor, o caráter hierárquico da ordem pré-capitalista européia contribuiria para explicar as sutilezas escolásticas, o desenvolvimento de sofisticadas teologias e sistemas metafísicos.

Não nos importa tanto o valor substantivo da construção teórica de Bloor. Serve-nos de exemplo de como um padrão rotineiro de linguagem pode ser relacionado de modo plausível a padrões de organizaçăo social, o que nos permite investigar os interesses sociais que operam a favor de sua reprodução.

A controvérsia entre os defensores do Programa Forte e os críticos da sociologia do conhecimento científico certamente prosseguirá, com novos lances e tentativas de mútua refutação. Não houve, de nossa parte, a intenção de oferecer uma argumentação conclusiva a este respeito. Pretendeu-se apenas apresentar, de maneira muito resumida, as principais idéias que orientam o Programa Forte da sociologia do conhecimento e a atividade intelectual dos sociólogos de Edimburgo.

Para concluir esta sumária exposição, cabe mencionar um último argumento. Bloor tem razão quando adverte seus críticos das diferenças de perspectiva que distinguem as disciplinas científicas. Alguns exemplos de conhecimento sem a intervenção de causas sociais, apresentados com o objetivo de refutar o Programa Forte, confirmam este tipo de erro. 
O fato de um rato de laboratório aprender sozinho o caminho que leva ao alimento constitui, por certo, um exemplo de conhecimento em que não houve intervenção de qualquer causa social. Bloor adverte que subterfúgio algum seria admissível com o objetivo de não reconhecer possibilidades semelhantes para o ser humano, as quais seriam certamente superiores às do rato. No entanto, o conhecimento que é objeto da sociologia não deve ser concebido com referência a situações-limite deste tipo, que possuem interesse, por exemplo, para as pesquisas de inteligência artificial. Para a sociologia do conhecimento, importam os casos paradigmáticos de conhecimento humano, entre os quais, certamente, devem ser incluídos o senso comum da atividade cotidiarıa e o conhecimento científico. Em ambos os casos, estaríamos lidando com instituições sociais.

O conhecimento que importa investigar tem uma objetividade que resulta precisamente de seu caráter intrinsecamente social. São crenças que não se sustentam na subjetividade de um observador isolado. $E$ isto dificilmente seria contrarrestado por experiências de laboratório (Bloor, 1982). 


\section{A Ciência entre \\ a Comunidade e o Mercado: \\ leituras de Kuhn, Bourdieu, Latour \\ e Knorr-Cetina}

Gilberto Hochman

INTRODUÇÃO

As disputas sobre o caráter especial do conhecimento e da prática científica, entre autores e perspectivas, nos campos da história, da filosofia e da sociologia da ciência, independentemente do que reivindiquem, terminam, quase sempre, de alguma maneira referindo-se aos indivíduos ou grupos de indivíduos que, na sociedade moderna, são considerados, por motivos que também são razão de disputa, os legítimos praticantes dessas atividades, produtores de conhecimento e árbitros do que seja ciência. De qualquer forma, e com isso todos concordam, acostumou-se a chamar esses indivíduos de cientistas.

Uma parte da bibliografia no campo da sociologia da ciência, descartando as proposições da epistemologia sobre verdades científicas imanentes, propõe uma abordagem que relaciona intimamente os mundos social e científico, remetendo-se, obrigatoriamente, à análise do relacionamento entre os cientistas, e destes com o mundo exterior, enfim, sobre qual é a base de organização e interação dos praticantes da ciência.

O objetivo deste trabalho é analisar como uma parte da literatura sociológica e histórica aborda e discute a interação e a organização dos cientistas na sua dimensão formalmente científica. Se isto é um problema considerado relevante por todos, o consenso termina aqui. E a discordância começa com a identificação e colocação das seguintes questões: qual deve ser a unidade organizacional da análise das práticas científicas? Como e por que atuam os cientistas? Como e por que se relacionam entre si? Como, por que e quando interagem com atores 
exteriores ao mundo científico? A partir dessas questões, reaparecem, como desdobramentos importantes, tradicionais antinomias como, por exemplo: normas versus interesses; solidariedade versus conflito; indivíduo versus comunidade; comunidade versus mercado; científico versus social; ciências exatas e naturais versus ciências sociais.

Escolhi para analisar e comparar, alguns trabalhos de autores que, com diferentes embasamentos teóricos e metodológicos, procuram enfrentar explicitamente as questões acima apontadas. Do trabalho renovador de Thomas Kuhn aos estudos etnográficos sobre a prática científica em laboratórios de Bruno Latour, Steve Woolgar e Karin Knorr-Cetina, passando pelos conceitos de Pierre Bourdieu, devidamente apropriados e retrabalhados pelos dois últimos, estão em debate permanentes temas como a comunidade científica, a sua existência ou não, a sua substituição por outra unidade analítica como, por exemplo, o mercado, e os padrões de interação dos cientistas.

Proponho-me abordar, neste trabalho, a forma pela qual cada um desses autores - Kuhn, Bourdieu, Latour e Knorr-Cetina - discute o tema da organização e interação dos cientistas na prática da ciência, procurando ressaltar as divergências entre as várias abordagens. É sempre bom lembrar que cometerei injustiças por me estar atendo a uma pequena parcela da obra de cada um. Porém, creio que essas escolhas permitem um bom rendimento analítico para ressaltar as diferenças entre os autores e destacar a relevância das questões por eles colocadas. Advirto que não discutirei todas as dimensões e conseqüências dos trabalhos escolhidos, mas apenas aquilo que está vinculado ao tema central do presente texto. De qualquer maneira, as opções metodológicas de cada um não são descartáveis, pois definem para onde cada autor olhará e, com isso, que tipo de organização e interação encontrará.

Abordarei a perspectiva de cada autor e as críticas que cada um faz ao trabalho dos demais. Por essa razão, a ordem da análise é cronológica, a partir da data de publicação dos trabalhos. De certo modo, a partir de Kuhn, cada autor irá criticar e refazer a idéia de comunidade científica. Assim, a leitura que farei indica um processo de debate e construção de conceitos e teorias, com referências mútuas entre os autores, e os trabalhos de Knorr-Cetina serão utilizados como uma crítica generalizada aos demais ${ }^{1}$. Ao final, como conclusão, se é possível concluir, ressaltarei as divergências e convergências e indicarei que, para além dos pontos de contato e de conflito teórico-metodológico, e das críticas

1 Apresentada a perspectiva de Kuhn, teremos Bourdieu leitor e crítico de Kuhn, depois Latour e Woolgar, leitores e críticos de ambos, e, por último, Knorr-Cetina, leitora e crítica de todos. 
que uns fazem aos outros, talvez estejamos diante de análises que possam ser pensadas de um modo mais integrado. Comunidade, campo científico, mercado ou arena transepistêmica? Com a palavra, os autores.

\section{THOMAS KUHN E A COMUNIDADE CIENTÍFICA COMO UNIDADE ANALÍTICA}

Iniciarei com uma definição: a comunidade científica é a unidade produtora e legitimadora do conhecimento científico. Esta concepção, que Thomas $S$. Kuhn descreve e analisa em The Structure of Scientific Revolutions ${ }^{2}$, está intimamente vinculada ao ponto central de seu trabalho, o conceito de paradigma. Para o autor, paradigma é um trabalho científico exemplar, que cria uma tradição dentro de uma área especializada da atividade científica ou, em outras palavras, são realizações científicas universalmente reconhecidas que, por um período de tempo, fornecem soluções modelares para uma comunidade científica. É preciso apontar para duas de suas características essenciais:

a) "suas realizações foram suficientemente sem precedentes para atrair um grupo duradouro de partidários, afastando-os de outras formas de atividade científica (...)" e

b) "simultaneamente suas realizações eram suficientemente abertas para deixar toda a espécie de problemas para serem resolvidos pelo grupo redefinido de praticantes da ciência" (Kuhn, 1978:30).

Ora, como o próprio Kuhn reconhece no seu posfácio de 1969, a definição de paradigma é circular, pois envolve o problema da adesão ou não de um grupo de homens que praticam a atividade científica a um estilo de trabalho definido por um paradigma. Nas palavras do autor, "paradigma é aquilo que os membros de uma comunidade partilham e, inversamente, uma comunidade científica consiste em homens que partilham um paradigma" (Kuhn, 1978:220).

Do ponto de vista empírico, identificar um paradigma é também, e ao mesmo tempo, identificar a comunidade de seus praticantes. Quero dizer, e o autor concorda, que se este conceito é central na sua obra, não tem nenhuma validade e operacionalidade sem a concepção de comunidade científica, formada por aqueles que aderem ao paradigma. E mais, se o paradigma é aberto o suficiente para a resolução de novos problemas, esta característica impõe à comunidade uma certa flexibilidade para incorporar novos praticantes e novas questões, dentro da tradição estabelecida. O paradigma existe porque, e somen-

2 Kuhn, 1962. As citações utilizadas ao longo do texto são da tradução brasileira, Kuhn, 1978. 
te porque, é adotado por um grupo de praticantes que, ao fazê-lo, constitui-se uma comunidade. A ciência não é a simples prática da verdade, mas aquilo que um grupo estabelecido entende e partilha como a melhor maneira de resolver e elucidar temas de investigação científica. Ou melhor, diria Kuhn, "a comunidade científica é um instrumento imensamente eficiente para resolver problemas ou quebra-cabeças definidos por seu paradigma" (Kuhn, 1978:208).

Portanto, o funcionamento de uma comunidade científica é condição de eficiência em épocas de ciência normal, quando o que está em questão é a resolução cotidiana de 'quebra-cabeças'. Nesses períodos, a dinâmica da comunidade é: um grupo de cientistas compartilha de certa tradição de fazer ciência na sua especialidade; esse grupo foi socializado e educado nos mesmos valores e regras, ou seja, no paradigma, além do que se vê e é reconhecido como responsável pela reprodução de um modo de praticar ciência, incluindo o treinamento dos que irão ser admitidos nessa comunidade e, é claro, o serão porque passarão a compartir dos padrões constitutivos da mesma.

A comunidade kuhniana detém o monopólio da prática científica estabelecida, portanto, fora dela não há salvação, pelo menos para os que desejam se tornar cientistas. Existe uma clara noção de autoridade - uma vez que a comunidade sanciona os seus membros - e de hierarquia, porque alguns de seus componentes, os que a ela pertencem há mais tempo e são eficientes na resolução dos problemas científicos, estão capacitados para treinar os mais novos nos padróes da comunidade. Porém, não há lugar para idiossincrasias. A hierarquia, a nosso ver, nada mais é do que um problema geracional. $O$ treinamento é dado com o objetivo estrito de socializar os neófitos na tradição da comunidade, ou melhor, nas práticas mais eficientes de resolução de problemas científicos. Nessa comunidade, os alunos de hoje serão os professores de amanhã. O professor-cientista é apenas porta-voz da tradição de uma comunidade, e não uma individualidade. Ser membro é ser capaz de resolver problemas dentro da tradição de trabalho compartilhada pelo grupo, tradição que é a base de comunicação e referência entre os seus membros.

A comunidade científica, nestas circunstâncias - e esse é um requisito definidor - é extremamente estável. Ela é composta por um grupo de cientistas que compartilha da capacidade de resolver eficientemente os problemas surgidos no trabalho científico, nas condições de ciência normal, apontando soluções difundidas e partilhadas. Nos períodos de ciência normal, há um grande comprometimento e um consenso por parte dos cientistas que partilham das mesmas regras e padrões de prática científica, que são os pré-requisitos "para a gênese e a continuação de uma tradição de pesquisa" (Kuhn, 1978:31). 
O paradigma é a herança cultural que os cientistas do presente recebem dos seus antepassados. Aceita como base para se pesquisar, essa herança é desenvolvida e elaborada nas suas pesquisas, e transmitida, como tal, aos novos e futuros membros da comunidade. Assim como a cultura, a transmissão do paradigma faz-se pelo treinamento, socialização e controle. E mais, para Kuhn, o treinamento/ensino deve ser autoritário e dogmático para produzir o máximo de adesão ao paradigma ${ }^{3}$. A comunidade se constitui e se reproduz mediante o consenso obtido por essa pedagogia e não por uma adesão racional a uma lógica científica. A ciência é convenção; a comunidade científica é, ao mesmo tempo, o lugar e o resultado dessa convenção. A ciência normal sempre se reproduz, self-validating, porque seu paradigma é sustentado por uma prática que supõe a sua correção, produzindo soluções e interpretações.

O isolamento 'sem paralelo' no mundo moderno é uma das características fundamentais da comunidade científica. Os cientistas relacionam-se e comunicam-se com seus pares de maneira quase exclusiva. Esse insulamento se dá, tanto em relação aos não-especialistas, quanto às exigências da vida cotidiana. Kuhn indica aqui, e voltaremos a esse ponto posteriormente, que essa relação exclusiva entre pares, em que o trabalho criador de um cientista é dirigido aos demais membros da comunidade, marca a diferença entre outras comunidades profissionais (como a de engenheiros e médicos) e a comunidade científica. E indo além, o insulamento é condição para que cada cientista possa concentrar sua atenção sobre os problemas que "se julga competente para resolver" (Kuhn, 1978:207), tendo em vista o instrumental disponível. A condição para a eficiência do trabaIho científico, para a pesquisa da ciência normal é, justamente, o seu isolamento da dinâmica social, o seu auto-enclausuramento, mesmo que a sua gênese tenha sido fortemente condicionada por relações sociais. Podemos destacar algumas características essenciais do funcionamento da comunidade científica kuhniana:

a) seus membros preocupam-se com a resolução de problemas relativos ao comportamento da natureza;

b) esses problemas são detalhes, ainda que haja uma preocupação mais global;

c) as soluções são coletivas;

d) o grupo que as partilha é formado exclusivamente por cientistas;

e) este grupo é árbitro exclusivo e competente para assuntos científicos;

f) em matéria científica, é ilegítimo o apelo a qualquer instância externa à comunidade científica (Kuhn, 1978:211).

3 Este ponto está desenvolvido na leitura de Barry Barnes sobre a questão do treinamento dos cientistas em Kuhn (Barnes, 1982, cap. 2). 
Para Kuhn, essa comunidade é a forma mais eficiente de empreendimento científico. As características que a definem são também a condição de sua eficácia, isto é, o seu padrão definidor é também o seu padrão normativo. Ao caracterizar a comunidade científica, Kuhn determina um padrão de eficiência para a prática da ciência.

A noção de 'grande comunidade' é relativizada pelo autor no seu posfácio de 1969. Admitindo a existência de várias escolas ou comunidades - os termos aparecem como equivalentes - Kuhn afirma que "há escolas nas ciências, isto é, comunidades que abordam o mesmo objeto científico a partir de pontos de vista incompativeis". Porém, pelo menos nas ciências naturais e exatas, a competição entre escolas termina com a instauração e desenvolvimento da ciência normal. O que existe são comunidades científicas diferentes que voltam sua atenção para objetos e assuntos diversos. A visão kuhniana seria a de uma comunidade científica mais global, "composta por todos os cientistas ligados às ciências da natureza", e de comunidades menores que corresponderiam às várias especialidades técnicas e científicas (Kuhn, 1978:221). Além de uma integração vertical, existiria um entrecruzamento horizontal das comunidades, com alguns cientistas pertencendo a várias delas, simultaneamente ou em sucessão. A comunicação entre as várias comunidades, por vezes, é bastante difícil; o mesmo não acontece dentro de um grupo científico que partilha da mesma tradição. O paradigma tende a definir de modo rígido o campo de estudos. Para Kuhn, a aceitação de um paradigma pode ser verificada com o surgimento de jornais, revistas especializadas, fundação de sociedades científicas, currículos de cursos universitários, citações, livros didáticos etc. Estas são algumas das formas de socialização e comunicação entre os membros do grupo.

A novidade trazida por Kuhn sobre a formação e funcionamento da comunidade científica, articulada com a criação/aceitação de um paradigma, é a noção de que o conhecimento científico da comunidade é uma convenção, com sua autoridade se baseando em um consenso sempre reproduzido. O paradigma e o conhecimento científico são criações e propriedades coletivas do grupo, e apresentam-se e são utilizados, de modo geral, de igual maneira por todos. Essa é a base da integração comunitária. É como se fosse uma linguagem e, como tal, conforme sugere Kuhn, "é intrinsecamente a propriedade comum de um grupo ou então não é nada. Para entendê-lo, precisamos conhecer as características dos grupos que o criam e o utilizam" (Kuhn, 1978:257). Com isso, ele recoloca o nosso problema inicial: a comunidade é a agência ao mesmo tempo criadora, legitimadora e reprodutora dessa linguagem: o conhecimento científico.

Essa comunidade, baseada na solidariedade e no compromisso, será estável enquanto for capaz de resolver os problemas científicos dentro da tradição compartilhada. Cotidianamente, ela canaliza seus esforços para a pes- 
quisa da ciência normal, "dirigida para a articulação daqueles fenômenos e teorias já fornecidos pelo paradigma", buscando aumentar seu alcance e precisão (Kuhn, 1978:43). A comunidade pode ser abalada no momento em que surgem as anomalias - casos que resistem a soluções dadas pelo paradigma vigente, ou que não são comparáveis às maneiras exemplares de resolução de problemas científicos.

Lembra-nos Barry Barnes que, para Kuhn, o treinamento dogmático e autoritário não impede o cientista de perceber e inferir por ele mesmo, mas ao contrário, essas competências são adquiridas por meio da pedagogia kuhniana ${ }^{4}$. O cientista bem treinado e socializado é altamente capacitado para perceber as anomalias, isolá-las e resolvê-las, utilizando o instrumental dado pela tradição comunitária. Portanto, o treinamento no paradigma garante uma comunidade sensível às anomalias e, quase sempre, capaz de incorporar esses casos excepcionais ao padrão vigente. Afinal, como vimos, o paradigma é aberto o suficiente para permitir desenvolvimentos e mudanças. Leia-se: a comunidade é razoavelmente aberta à incorporação de novidades, desde que lastreadas, de alguma forma, pela tradição científica. Ela necessita dessa flexibilidade para manter a sua estabilidade e existência. Em períodos de ciência normal, as anomalias são tratadas dentro da tradição científica vigente e o fracasso de um cientista ou de um grupo em alcançar a solução para determinados problemas/anomalias "desacredita o cientista, não a teoria". (Kuhn,1978:111). Na pesquisa normal, o fracasso será sempre do cientista e não do seu instrumental, o paradigma. Até que um dia...

Em determinados períodos da prática científica, ao longo da história, a comunidade não encontra resolução para determinados problemas dentro dos paradigmas existentes. São anomalias persistentes, intratáveis, resistentes ao instrumental da tradição comunitária. Surgem explicações não-tradicionais para os problemas anômalos, instaura-se a instabilidade na comunidade científica confrontada com um mundo mais aberto a alternativas. A 'consciência da anomalia', ao persistir por muito tempo, instaura uma crise crescente na comunidade, com um aumento da insegurança profissional pelo fracasso, repetido, da utilização do padrão tradicional. Estamos em uma época de crise, em que sua ultrapassagem e solução deve ser vista, em Kuhn, como uma resposta não-tradicional para os problemas surgidos dentro da ciência normal, e não-resolvidos por uma tradição científica estabelecida. Para o autor, a crise significa que é chegada a hora da renovação dos instrumentos de uma comunidade científica. O critério para identificarmos esse momento seria o acúmulo de problemas não-equacionados pela ciência normal e a instabilidade gerada na comunidade (Kuhn, 1978:105). Te-

4 Barnes, 1982:20. 
mos uma Revolução Científica (ou uma Revolução científica?), onde um paradigma é substituído parcial ou totalmente por um outro completamente novo e incompatível com o anterior.

Nesse momento, o da transição do período pré para o pós-paradigmático, é que Kuhn reconhece a competição e o conflito entre escolas pelo domínio do campo. A comunidade torna-se mais tolerante e aberta, permitindo um nível de conflito e competição não-existente na ciência normal. Porém, para o autor, "mais tarde, no rastro de alguma realização notável, o número de escolas é grandemente reduzido - em geral para uma única" (Kuhn, 1978:222). O novo paradigma, aceito agora como a forma mais eficiente de praticar a ciência, reorganiza a comunidade científica, que pode ser composta de novos ou antigos membros, porém com uma visão de ciência e de mundo completamente diferente da anterior. Não há tradução de um paradigma para outro, de uma comunidade para outra. São linguagens distintas, ou como comenta o autor, "as diferenças entre paradigmas sucessivos são ao mesmo tempo necessárias e irreconciliáveis" (Kuhn, 1978:137). A comunidade científica passa a operar em um novo mundo, ela mesma completamente modificada. Provavelmente será composta de novos praticantes, livros, textos e professores. A revolução esgota-se a partir da imposição de uma nova tradição que orientará a pesquisa da ciência normal. Transforma-se em tradição e é apresentada, mediante textos, obras filosóficas e manuais, como o "resultado estável das revoluções passadas" (Kuhn, 1978:173). As histórias da disciplina e de sua comunidade são registradas como etapas evolutivas, cumulativas e necessárias.

Nada - nem a ciência, nem a comunidade científica, nem o mundo - será como antes, porém tudo é apresentado como se fosse uma continuidade natural do que foi, do passado. A revolução científica seria uma necessidade, porque vital para o desenvolvimento e o progresso da ciência. Porém, as mudanças podem não ser revolucionárias, e na maioria das vezes não o são, dando-se na prática da ciência normal. É preciso ressaltar que, na maioria dos casos, ocorrem mudanças de paradigma que não afetam todos os grupos que se dedicam ao trabalho científico. Assim, nem todas as comunidades são reorganizadas por uma revolução científica.

Uma questão importante para compreendermos a natureza e constituição da comunidade científica kuhniana é o tema da conversão comunitária de um paradigma a outro. Como assinalamos inicialmente, as relações entre comunidade e paradigma são indissociáveis. Insistimos: a comunidade científica é um conjunto de homens que partilham um paradigma, e este o é porque uma comunidade o compartilha. Essa relação circular aparece durante todo o texto de Kuhn, e arriscaríamos dizer que ele coloca dois problemas insolúveis, porque incompatíveis. O primeiro está na prioridade da comunidade como instância de produção, aceitação e legitimação do conhecimento científico, portanto seria como se ela 
tivesse precedência sobre o paradigma. De outro lado, em trechos de seu trabaIho, em especial nos dois últimos capítulos, Kuhn, apesar de enfatizar o caráter mais contextual do conhecimento, acaba confessando que o conhecimento científico é algo especial, dando a precedência a ele, à dimensão cognitiva como fundadora da comunidade. Afinal, quem vem primeiro: o conhecimento ou a comunidade? Kuhn confessa que não tem uma resposta para isso. Vejamos agora esta questão.

Em momentos de crise, a competição entre paradigmas e grupos instaura-se desordenando a prática tradicional, e a ordem na ciência só se restabelece quando um dos grupos "experimenta a conversão", isto é, a alteração de seu paradigma. A pergunta fundamental aparece nas palavras de Kuhn: "O que leva um grupo a abandonar uma tradição de pesquisa normal por outra?" (Kuhn, 1978:183). Como podem se dar a comunicação e a passagem entre dois mundos incomensuráveis? Certamente, segundo Kuhn, não se converte um grupo pelas provas científicas, nem pela demonstração do erro da tradição anterior. A resistência é muito forte porque os cientistas acreditam que a ciência normal conseguirá, cedo ou tarde, equacionar as anomalias. Não esqueçamos do fundamental. A comunidade científica obtém sucesso via ciência normal, o estágio eficiente da produção científica. Isso explicaria muito da resistência de membros da comunidade em abrir mão do seu paradigma.

Mas, como e quando ocorre a conversão? A conversão se dá, em parte, pela demonstração, sempre comparativa, de que o novo paradigma permite uma solução mais eficiente dos problemas científicos. Porém, para Kuhn, essa adesão será sempre individual. O novo paradigma vingará se conquistar adeptos que desenvolvam suas potencialidades, acreditando mais no seu 'rendimento futuro' do que na eficiência da tradição vigente. Teríamos não uma adesão grupal, mas um assentimento individual crescente, que aumenta a capacidade de persuasão do paradigma, criando a percepção que é melhor pertencer à nova comunidade.

O argumento aqui exposto é a descrição de uma dinâmica individualista, existindo um cálculo subjetivo sobre a eficiência do paradigma vigente e uma aposta no futuro. Contudo, não há interesses pessoais em jogo, mas o desejo de contribuir para o progresso da ciência. A crise e a revolução científicas são os únicos momentos nos quais prevalece a opção individual do cientistas diante da estrutura comunitária. A rigidez de alguns de aceitar o novo paradigma seria compativel com a capacidade da comunidade de trocar de paradigma no espaço de uma geração. Para Kuhn, essa rigidez fornece à comunidade um indicador "de que algo vai mal" (Kuhn, 1978:208). Portanto, o processo de conversão acentua o dilema kuhniano: o novo paradigma é superior e persuadirá a comunidade - as revoluções são necessárias! - mas a comunidade é a única instância que pode reconhecer um conjunto de conhecimentos como superior aos existentes. 
Ao abordar os problemas da ciência e do conjunto de seus praticantes dos pontos de vista histórico e sociológico, Kuhn reivindica o caráter convencional da ciência e aponta a especificidade da sociedade moderna de manter e delegar poder de escolha científica a "um tipo especial de comunidade" (Kuhn, 1978:210). Porém, no capítulo final de seu livro, Kuhn deixa claro que os cientistas não têm autoridade cognitiva para operar com o que quiserem, uma vez que a natureza não é simplesmente um resultado de um acordo e do consenso. $E$ pergunta: "O que deve ser o mundo para o homem conhecê-lo? [...] o mundo do qual essa comunidade (científica) faz parte também possui características especiais?" (Kuhn, 1978:210).

Isso nos leva a pensar que a solução para a tensão que atravessa o seu livro, mesmo que Kuhn afirme não ter respostas para as perguntas acima mencionadas, está, ainda, no caráter diferenciado da ciência e da comunidade que a pratica. Essa distinção não é apenas resultado de exigências e delegações da sociedade moderna. Se não existe nenhum critério epistemologicamente superior ao julgamento da comunidade científica, Kuhn admite que este também é insuficiente para fornecer todas as credenciais às proposições científicas que demandam reconhecimento como verdades. Não é apenas um problema de quem detém a autoridade (e o poder) na definição do que é científico e do que não é. A natureza possui características especiais, a própria noção de progresso científico, de aprimoramento das teorias indica que, para Kuhn, "não vale tudo". Mas, cremos que investigar o progresso do conhecimento científico (da natureza) só é possível por meio da única comunidade reconhecida para viabilizá-lo. O paradigma governa os praticantes da ciência, não a natureza. Por fim, se a natureza e o conhecimento científico existente sobre ela não são quaisquer coisas, entendêlo é "conhecer as características dos grupos que o criam, e utilizam" (Kuhn, 1978:256). Com Kuhn está dada a primazia, possível, pelo menos metodológica, para o estudo da comunidade científica.

\section{BOURDIEU PROCURA A COMUNIDADE CIENTÍFICA E DESCOBRE O MERCADO}

Em artigo bastante conhecido ${ }^{5}$, Pierre Bourdieu introduz a noção de campo científico, em clara oposição ao conceito de comunidade científica de Kuhn, apesar de incorporar muitos dos seus termos. Para Bourdieu, a noção de comunidade científica autônoma, insulada e auto-reprodutora, com cientistas neutros

5 Bourdieu, 1983. Todas as citações referem-se à versão inglesa, Bourdieu, 1975. Para uma visão mais geral de suas concepçōes utilizamos: Bourdieu, 1981. 
e interessados somente no progresso da sua disciplina, esconde, mais do que elucida, a dinâmica das práticas científicas na sociedade moderna. A autonomia da comunidade científica (e da ciência), como requisito para a eficiência do trabalho científico, deve ser entendida a partir da natureza da sociedade em que ela se insere.

A explicação sobre a produção de conhecimento passa, agora, com Bourdieu, pela concepção de que esta produção é um caso especial da produção e distribuição capitalista de mercadorias. Portanto, aqui, a ciência só pode ser entendida a partir da determinação social do seu conteúdo. Para Bourdieu, a idéia de uma ciência neutra é "uma ficção interessada que habilita seus autores a apresentar uma representação do mundo social, neutro e eufêmico (...)" (Bourdieu, $1975: 37)^{6}$. É preciso revelar o que está escondido por trás do discurso e do esforço desinteressado da comunidade kuhniana em busca do progresso científico. Sai a ciência, entra a sociedade.

Deixemos, agora, Bourdieu definir o que é campo científico, seu principal conceito, uma alternativa à noção de comunidade científica:

Enquanto sistema de relações objetivas entre posições adquiridas (em batalhas anteriores), o campo científico é o locus de uma competição no qual está em jogo especificamente o monopólio da autoridade científica, definida, de modo inseparável, como a capacidade técnica e o poder social, ou, de outra maneira, o monopólio da competência científica, no sentido da capacidade - reconhecida socialmente - de um agente falar e agir legitimamente em assuntos científicos (Bourdieu, 1975:19).

O campo científico é um campo de lutas, estruturalmente determinado pelas batalhas passadas, no qual agentes/cientistas buscam o monopólio da autoridade/competência científica. Os conflitos que ocorrem no e pelo domínio desse campo são entre agentes que têm lugares socialmente prefixados no mesmo, assim como qualquer agente na sociedade, e são fundamentalmente interessados, isto é, desejam maximizar, e se puderem, monopolizar, a competência/autoridade científica - reconhecida pelos pares. O campo científico instaura-se com um conflito pelo crédito científico. Portanto, o campo científico como locus de análise se distancia muito da comunidade de especialistas que cooperam para o avanço do conhecimento.

Mas, afinal, o que é crédito científico? É um capital simbólico, não-monetário - leia-se autoridade/competência científica -, uma espécie particular de capital "que pode ser acumulada, transmitida e até reconvertida, sob certas condi-

6 Todas as traduções são minhas. 
ções, em outros tipos de capital" em um mercado específico, o da produção do conhecimento científico (Bourdieu, 1975:25). Portanto, Bourdieu não faz apenas uma analogia do campo científico com o mercado capitalista, mas, indo além, propõe que esse é mais um mercado particular dentro da ordem econômica capitalista.

A intenção da análise em questão seria a de eliminar qualquer tentativa de discriminação entre interesse/determinação científica e interesse/determinação social ou, em outras palavras, entre uma abordagem internalista e epistemológica e outra externalista e sociológica. O cientista, um homem no/do mercado escolhe, decide e investe, tendo como referência "a antecipação das oportunidades médias de lucro (especificadas elas mesmas em termos do capital já obtido)" (Bourdieu, 1975:22). Toda escolha científica é uma estratégia política de investimento dirigida para a maximização de lucro científico, isto é, o reconhecimento dos pares-competidores. $\mathrm{O}$ próprio interesse dos cientistas em certas áreas de estudo deve ser analisado como uma avaliação das possibilidades de crédito científico. Muitos cientistas se dedicam a determinados temas (por exemplo, a AIDS) porque uma descoberta, ou contribuição nesta área exponenciaria o seu capital simbólico. Porém, como em qualquer mercado, o aumento do número de competidores pode levar à diminuição das expectativas de taxas de lucro elevadas, gerando a migração desses cientistas/investidores para outras áreas menos competitivas, que podem oferecer para o mesmo investimento uma probabilidade maior de retorno.

O que está em jogo no campo científico é essa espécie particular de capital social, a autoridade científica, que é o poder de impor uma definição de ciência que será tão mais apropriada quanto permita ao cientista ocupar "legitimamente a posição dominante, atribuindo a mais alta posição na hierarquia dos valores científicos para as capacidades científicas que ele detém, pessoalmente ou institucionalmente" (Kuhn, 1978:23). A vitória, o crédito, o capital obtido são daqueles que impõem uma (a sua) definição de ciência. Se, para Bourdieu, a autoridade/competência científica é um capital que pode ser acumulado, transmitido e convertido em outras formas de capital, inclusive monetário, o processo de acumulação do capital científico seria idêntico ao de qualquer outro tipo: inicia-se com a acumulação primitiva no processo educacional e nas primeiras etapas da vida profissional (origem do diploma, cartas de recomendação); tem continuidade após a obtenção de um capital suplementar com o reconhecimento dos seus primeiros trabalhos, títulos e publicações; e se consolida a partir da determinação de seu lugar no campo, que será definido pela possibilidade de acumulação permanente de capital científico e de impor-se como autoridade na respectiva área. Uma dada estrutura de distribuição de poder - uma distribuição de capital científico entre os cientistas e instituições em competição orienta as estratégias e seus investimentos no presente; inclusive as aspirações científicas de cada um dependem do capital já acumulado. 
Essa competição capitalista, justamente por ser capitalista, implica que o seu produto está amplamente condicionado pelos recursos que cada agente e instituição possui ao entrar na mesma. O campo científico não é o resultado da simples interação dos agentes. Mesmo as regras desse jogo, válidas igualmente para todos, estão definidas - como expressão de conflitos anteriores - pela autoridade científica estabelecida, que tenderá a se reproduzir e a acumular capital científico, mantendo o seu lugar dominante no campo. A definição do que está em disputa no campo científico também faz parte da luta científica. Bourdieu vai além de um simples isomorfismo, de uma correspondência, propondo uma relação direta, praticamente sem distinções, entre campo científico e estrutura da sociedade. O campo é uma dimensão da sociedade.

A especificidade do campo científico, e essa percepção também aparece em Kuhn e Latour, é que os produtores de conhecimento têm como consumidores/clientes os seu próprios pares/concorrentes. Quanto mais autônomo for o campo, mais um cientista/produtor deve esperar o reconhecimento do valor de seus produtos (reputação, prestígio, autoridade) de consumidores que são produtores concorrentes. Só os que participam dessa competição é que podem se apropriar simbolicamente desse produto e avaliar seu mérito. $\mathrm{O}$ apelo a uma autoridade externa ao campo retira crédito, caindo o cientista, e a palavra é perfeita para Bourdieu, em descrédito. A autonomia do campo é condição para a atividade científica e para a existência desse tipo específico de capital. O reconhecimento dos pares/concorrentes se faz pelo valor distintivo do produto e pela originalidade que traz aos recursos científicos acumulados. É por isso - e não "em nome do progresso" - que existe a prioridade nas descobertas, nas invenções que geram produtos diferentes e originais, escassos no mercado científico, valorizando o nome do cientista, que procurará manter e incrementar seu capital. Daí, por exemplo, a estratégia dos autores de artigos coletivos de ordenar os seus nomes em um artigo tendo em vista o capital científico acumulado, procurando minimizar qualquer perda de "valor distintivo".

Para o autor em questão, o mercado de bens científicos tem suas leis, que nada têm a ver com valores, ética ou moral. Não haveria ação desinteressada, e até $o$ interesse pelo desinteresse seria uma estratégia dissimulada dos agentes (Kuhn, 1978:26). A crítica de Bourdieu é à idéia de tradições e valores imputados a uma comunidade científica. Elas são, também, estratégias utilizadas desigualmente por uma ordem científica composta por desiguais. Ao procurar romper com a visão comunitária de Kuhn, que é criticado pelo silêncio em relação aos interesses, e instaurando uma visão mercantil da produção científica, Bourdieu pretende reintroduzir a sociedade capitalista de classes na análise da dinâmica científica. A comunidade está longe de ser neutra, cooperativa, indiferenciada, desinteressada e universalista, o "sujeito das práticas" impondo e inculcando a todos os membros seu sistema de valores e regras. Ao contrário, é o lugar da 
competição, da desigualdade, com indivíduos racionais e maximizadores, e mais, reproduzindo o diferencial de poder que existe na sociedade. Por isso, Bourdieu propõe a noção de campo como uma recusa ao termo comunidade, para ele um dissimulador da dinâmica real da ciência.

O campo científico é um lugar de luta desigual, entre agentes diversamente dotados de capital, portanto, desigualmente capazes de impor seus produtos e se apropriarem do resultado do trabalho científico produzido pelos pares/concorrentes. $\mathrm{O}$ consenso existe como uma doxa, isto é, como "o agregado de pressupostos que os antagonistas desejam como auto-evidentes e fora da área de argumentação e de disputa porque constituem a condição tácita do argumento" (Kuhn, 1978:35). É o consenso a respeito dos objetos do conflito; do que merece ou não ser levado em consideração. Esvaziando a ciência de qualquer conteúdo especial, Bourdieu afirma, categoricamente, que a sua base não é outra senão a crença coletiva em seus fundamentos, que o seu campo produz e pressupõe (Kuhn, 1978:35). A legitimidade e autonomia do campo científico será tanto maior quanto maior for a "ausência" da sua determinação social. A autonomia da ciência é o resultado mais perfeito desse processo.

O campo científico, assim como a sociedade, está dividido entre dois pólos:

a) o dos dominantes, que ocupam a hierarquia superior na distribuição de capital científico e que podem impor a definição de ciência que se conforma com seus interesses; e

b) o dos dominados, com pouco ou nenhum capital, situando-se na hierarquia inferior do campo.

Bourdieu observa três possibilidades estratégicas para esses agentes: a) a de conservação, por parte dos dominantes; b) a de sucessão - a ascensão "por dentro" do campo, em que os agentes buscariam ascender e acumular crédito nos limites autorizados do campo, tendo, assim, uma carreira previsivel e os lucros prometidos, sucedendo, com o tempo, àqueles que estão na hierarquia superior; e c) de subversão - "ascensão por fora", em que os pretendentes se recusam a aceitar o ciclo de troca de reconhecimento com os detentores da autoridade científica. Neste caso, a acumulação primitiva se fará mediante uma ruptura, uma revolução, tendo como consequêencia a obtenção de todo o crédito, sem nenhuma contrapartida para os até então dominantes.

Portanto, diversamente de Kuhn, que vê a manutenção e a ruptura com o paradigma vigente como respostas ao processo de pesquisa normal, Bourdieu encara a manutenção, o consenso e a ruptura como parte da estratégia dos agentes na busca de crédito científico. Normas, valores, consenso e recompensas não são as causas, mas os resultados da atividade social, que existe através das 
estratégias adotadas pelos investidores na busca de maximização de capital simbólico. Todos querem maximizar os lucros, obter, acumular e manter o seu capital científico, a autoridade/competência científica reconhecida.

Com mais cuidado, porém, percebe-se que a própria revolução contra a ciência estabelecida se faz no campo científico, onde teríamos uma revolução permanente, uma ruptura contínua, "sem distinções entre fases revolucionárias e ciência normal" (Kuhn, 1978:34). A noção de revolução científica de Kuhn seria mais apropriada para o início da ciência moderna e não para o seu desenvolvimento contemporâneo. Todas as estratégias acabam perdendo o sentido porque a acumulação de capital necessário à realização das revoluções e o capital por elas gerado faz com que inovações "ocorram crescentemente de acordo com procedimentos regulares de uma carreira" (Kuhn, 1978:34). Com o desenvolvimento da ciência, aumentam os recursos acumulados e o capital necessário à sua apropriação, tornando o mercado do produto científico cada vez mais restrito a concorrentes mais aparelhados e com mais capital científico acumulado. Não há saída, a revolução científica e a própria ciência normal is business of the richest. Este mercado de cientistas/empresários tende à oligopolização.

A comunidade científica tem a sua existência negada, e transforma-se em mercado científico, só que não um mercado de concorrência perfeita. A chance de cada agente ser bem-sucedido depende da posição na estrutura do campo, do mercado. Nem todos têm as mesmas oportunidades. O campo científico de Bourdieu é um espaço socialmente predeterminado, e não o resultado puro e simples da interação dos agentes ${ }^{7}$. Bourdieu, assim como o próprio Kuhn, opera a sua análise no nível macrossocial, em que os agentes individuais apesar de suas estratégias racionais e maximizadoras, têm suas oportunidades e decisões determinadas ou anuladas pela estrutura do campo, que reproduz a sociedade. A ordem cientíica é construída na e pela "anarquia das ações auto-interessadas" , como um mercado auto-regulável (Kuhn, 1978:36). Ao não aderir ao individualismo e não ter uma assunção comportamental, Bourdieu recorre a alguma coisa que, ex-ante, ou mesmo fora do campo, organiza o entrecruzamento das ações anárquicas. Essa "mão invisível" é a estrutura social.

A análise de Bourdieu é pouco normativa, porém crítica das condições e determinações sociais da prática científica. Inclusive a sociologia da ciência deveria ser submetida à crítica, admitindo uma reflexividade no sentido discutido por David Bloor $^{8}$. E não somente isto. Segundo alguns autores, a ciência não é relevante nesta

7 Para Bourdieu, não é livre; é condicionada pelo aprendizado, no âmbito e por meio da estrutura social vigente, que fornece ao agente um mapa e um roteiro finito para a sua ação e relação com a realidade social.

8 Ao definir as premissas do seu "programa forte" para a sociologia do conhecimentão científico, Bloor afirma que neste programa a análise tem de ser reflexiva, isto é, aplicável, também, a si mesma, uma vez que "o seu padrão de explanação deve ser aplicado, em princípio, à própria sociologia" (Bloor, 1976:5). 
análise, pois, para Bourdieu, é um corpo de conhecimentos como muitos outros, produzido por atores interessados na/da sociedade capitalista, ainda que ele explicite as condições de autonomia da produção científica que podem levar, como anuncia o título do artigo em questão, ao "progresso da razão"9. Por fim, o autor, ao olhar para a comunidade científica autônoma e neutra, descobre o mercado.

\section{LATOUR VAI AO LABORATÓRIO E ENCONTRA O CICLO DE CREDIBILIDADE}

Da macro para a microanálise da ciência. A proposta metodológica de Bruno Latour e Steve Woolgar em Laboratory Life ${ }^{10}$ - a descrição da ciência "tal como ela acontece" (as it happens) - é uma reação tanto às análises que atribuem um lugar especial ao conhecimento científico, conseqüentemente, à própria noção de comunidade científica, quanto aos críticos desta postura que, ao analisarem sociologicamente o conhecimento científico, acabam por não atentar para a prática da ciência como ela ela é produzida atualmente. Estes preocupam-se mais com uma sociologia dos cientistas, com os efeitos em larga escala da ciência, sua recepção, aceitando, como dado, o produto da prática científica, e nesse caso, mantendo a ciência como algo a parte, 'misterioso'.

É preciso rever essas atitudes epistemológicas em relação à ciência. Então, "vá ao laboratório e veja", sugerem Latour, Woolgar e Knorr-Cetina, à produção do conhecimento científico. Isto implica uma recusa a qualquer privilégio epistemológico em face da descrição etnográfica das práticas científicas. Em vez de impor categorias e conceitos estranhos ao mundo dos observados, os autores defendem que o fenômeno deve ser analisado contextualmente, tendo em vista o que os participantes/obsenados consideram como relevante, e são eles, e só eles, que podem validar a descrição (Latour \& Woolgar, 1979:38). A proposta desses autores é penetrar nesse universo místico "para construir um relato baseado na experiência do contato íntimo e diário com cientistas de laboratório (...)". (Latour \& Woolgar, 1979:21). Para os autores, a reflexividade é entendida como o exame da atividade científica com métodos que são similares aos dos praticantes observados. Neste sentido, a exigência de reflexividade do "programa forte" de Bloor encontraria sua viabilidade nos estudos de laboratório. O estudo de laboratório deve investigar como a ordem científica é criada a partir do caos, em um processo no qual o observador é tão construtor de fatos quanto o cientista observado. Não há diferença de status epistemológico entre a construção dos fatos pelo cientista e o relato deste processo, também uma construção, pelos sociólogos.

9 Latour \& Bowker, 1987:717-8.

10 Latour \& Woolgar, 1979. Todas as citações ao longo do texto referem-se a este livro. 
O laboratório é o local de construção de fatos, envolvendo homens, máquinas, experiências, papéis e estratégias. Um sistema cujo resultado é a convicção ocasional de alguns de que algo é um fato (Latour \& Woolgar, 1979:105). O desafio do trabalho etnográfico é a desconstrução de um hard fact, mostrando quais são os processos que operam na remoção das circunstâncias sociais e históricas nas quais esta construção se dá. Para Latour e Woolgar, um artefato se torna um fato quando perde todas as suas qualificações espaciais/temporais, sendo incorporado em um amplo campo de conhecimentos. O cientista é um gerador de ordem em face do caos. Como ordenador, esse cientista tem o mesmo objetivo da comunidade/paradigma kuhniano, criar condições estáveis para o experimento.

O Laboratory Life fornece um retrato minucioso do funcionamento das práticas científicas e da própria ciência, bem diferente das análises que privilegiam as macrodimensões da vida social. Cientistas e grupos de trabalho aparecem como estrategistas, negociadores, calculadores, mobilizadores de recursos de todos os tipos, em permanente competição. Enfim, fazem parte de um mundo onde existem apenas dois tipos de consenso, que dizem respeito: à tradição em que se inserem, quanto ao passado da disciplina e à sua base conceitual; e ao fato de que os recursos utilizados na competição devem ser apresentados e reconhecidos por todos como científicos. Sendo assim, a disputa entre cientistas, laboratórios e instituiçeõs se dará na fronteira do conhecimento, em uma competiçáo muito semelhante àquela do pluralismo político e do mercado econômico capitalista.

Ir ao laboratório é se deparar com um ordenamento dinâmico e instável, com uma área de consenso mínima. O exemplo da reconstituição feita por Latour e Woolgar da construção do Thyrotropin Releasing Factor (Hormone), ou $\operatorname{TFR}(\mathrm{H})$, é crucial, porque implicou um processo de competição entre vários laboratórios e cientistas, em que um deles conseguiu redefinir, em um certo momento, os objetivos da pesquisa - obtain structure at any/all cost - e os recursos econômicos, humanos e tecnológicos pelos quais essas estruturas poderiam ser determinadas (Latour \& Woolgar, 1979:120-124). Com isso, elevaram-se vertiginosamente os custos da pesquisa, modificando-se todos os seus critérios. Foram eliminados da disputa praticamente todos os grupos concorrentes que não puderam mobilizar o volume de recursos necessário para a nova escala da competição $^{11}$. E mais, as contribuições desses grupos e cientistas, até então na disputa, são desacreditadas e descartadas porque avaliadas sob os novos critérios impostos pelos vencedores. Estamos diante de um novo equilíbrio, frágil, que, longe de refletir um campo estático dividido entre dominadores e dominados, se estrutura em uma competição permanente que, a qualquer momento, por insucesso ou

11 Aqui, Latour e Woolgar tornam mais refinada a análise de Bourdieu sobre a imposição da autoridade científica no campo, mostrando empiricamente como isso é feito. 
mobilização de outros cientistas, pode levar à reorganização de toda a área ou do campo de pesquisa - inclusive, as posições dos cientistas na área de pesquisa são voláteis e dependem de habilidade estratégica.

No caso analisado por Latour, o grupo vencedor modificou todo o campo a partir de suas novas posições, que continuaram relativas porque dependentes das estratégias subseqüentes dos demais participantes do campo. Os cientistas podem ser observados como estrategistas "escolhendo o momento mais oportuno, engajando-se em colaborações potencialmente frutíferas, avaliando e ansiando por oportunidades". As posições relativas no campo, ao serem alteradas, modificam todo o campo. A habilidade política estaria no centro da prática científica: quão i , relhor político e estrategista for o cientista, melhor será sua ciência (Latour \& Woolgar, 1979:213).

Ao final do processo, o TRF $(\mathrm{H})$ tornou-se apenas uma simples estrutura de três aminoácidos, em que anos de esforços, negociações, investimentos e conflitos para a sua construção passam a ser irrelevantes para aqueles que o incorporaram e utilizam como um conhecimento estabelecido. $\mathrm{O}$ artefato tornou-se um fato apresentado sem história. Temos, assim, um fato, uma caixa-preta, ou mesmo, se utilizarmos a gramática kuhniana, um paradigma. O custo para abrir essa caixa-preta, para refazer a sua construção, tornou-se alto demais para que alguém queira contestar uma proposição científica que se estabilizou como fato ${ }^{12}$.

Ao penetrar no laboratório, o etnógrafo deve preocupar-se com "seqüências de trabalho, networks e técnicas de argumentação", evitando a adoção do cientista individual como ponto de partida ou unidade central de análise (Latour \& Woolgar, 1979:118). A própria distinção entre o indivíduo e o trabalho feito por ele é um recurso importante na construção dos fatos. Por isso, é preciso analisar a construção das carreiras individuais que se dá no curso da construção dos fatos, já que a própria noção do cientista como indivíduo é conseqüência da dinâmica e da competição que ocorre dentro do laboratório. Nesse sentido, Latour e Woolgar propõem a recuperação e modificação da noção de crédito de Bourdieu, propondo o que denominam de uma abordagem "quase-econômica" para a ação dos cientistas e suas relações. Assim, recolocam o problema da organização da ordem científica: "O que motiva um cientista a fazer o que ele faz?" (Latour \& Woolgar, 1979:189). Como e por que age um cientista? Existe uma comunidade científica ou um mercado científico? Como ela/ele se estrutura? Como se dá a relação entre cientistas?

Observando o laboratório, os autores concluem que, certamente, não são as normas inculcadas pelo treinamento que orientam os cientistas, "no máximo,

12 A abertura de uma caixa-preta é um tema mais desenvolvido por Latour em: Latour, 1987, principalmente no cap. 2, onde o autor discute as dificuldades de criar objeções a experiências e interpretações de um laboratório. 
normas simplesmente delineiam tendências gerais no comportamento" (Latour \& Woolgar, 1979:190-191). No lab life o apelo às normas é raro, geralmente instrumental, e a linguagem/conversação dos cientistas está repleta de termos econômicos, como investimento, oportunidades e retorno. Segundo Latour e Woolgar, é impossivel saber se essa linguagem econômica corresponde aos motivos reais dos cientistas ou se são apenas justificativas. De qualquer forma, mesmo que o modelo econômico não seja a melhor explicação para o comportamento dos cientistas, estes autores consideram que a interpretação por normas sociais é também inadequada (Latour \& Woolgar, 1979:191).

A idéia de que os cientistas agem visando ao crédito, no sentido que Bourdieu dá ao termo - reconhecimento e recompensa via imposição da autoridade científica -, é relativizada como um fenômeno secundário, já que apenas em algumas ocasiōes os cientistas se referem ao crédito como reconhecimento do mérito. $\mathrm{O}$ crédito como recompensa (as reward) não seria o maior objetivo da atividade científica. Os autores propõem uma ampliação do significado de crédito, associando-o com "crença, poder e business activity" (Latour \& Woolgar, 1979:194). A observação do lab life sugeriria a extensão do conceito de crédito para credibilidade (credibility). Essa ampliação mantém, como em Bourdieu, elementos de cálculo econômico em que o cientista/investidor avalia as oportunidades do campo. Só que, agora, o objetivo primeiro, e principal, da atividade científica, é o reinvestimento contínuo dos recursos acumulados, formando um ciclo de credibilidade, uma clara associação entre o ciclo do cientista e o ciclo de investimento de capital. Para Latour e Woolgar o comportamento do cientista é similar ao do investidor de capital (Latour \& Woolgar, 1979:197).

Portanto, seguindo com Bourdieu, Latour propõe a aplicação de um modelo econômico a um comportamento não-econômico. Porém, se credit is reward, credibilidade é a atualização das habilidades do cientista para fazer ciência. Este conceito explicaria como, no caso do laboratório estudado, alguns cientistas, pouco citados e reconhecidos no início e ao longo de grande parte da pesquisa - que pela simples idéia de crédito como reconhecimento teriam suas carreiras rapidamente abortadas e fracassadas -, obtiveram recursos e apoio para levar o projeto adiante, no que foram bem-sucedidos. $E$, como vimos mais acima, foram capazes, em um momento crucial da disputa científica, de aumentar os custos de reinvestimento de outros grupos, excluindo-os da disputa.

Sendo o cientista um investidor em credibilidade - recompensa, confiança, influência, reputação na capacidade de responder no futuro às expectativas e investimentos do presente -, ele avaliará a qualidade de suas informações, os seus receptores, as probabilidades de convencê-los e sua estratégia de carreira, e buscará, permanentemente, a conversão de uma forma de credibilidade em outras. A idéia de ciclo de credibilidade torna possível compreendermos essa 
conversão em dinheiro, equipamentos, informações, prestígio, credenciais, áreas de estudo, argumentos, papers, livros, prêmios, vinculando, assim, o cientista ao mundo exterior ao laboratório, por exemplo, com agências de financiamento, leitores, fornecedores etc. (Latour \& Woolgar, 1979:200-201). Neste ponto, Latour e Woolgar invocam um ciclo que se viabiliza a partir da transformação de valores de uso em valores de troca, base para essa conversão, tanto mais lucrativa quanto mais acelerada for a reprodução do ciclo de credibilidade (Latour \& Woolgar, 1979: 207, nota 9). Este ciclo conecta estratégias de investimento, teorias científicas, sistemas de recompensas e educação, permitindo que observador e observado transitem pelos vários aspectos das relações sociais na ciência, a partir do laboratório. E mais, algo que será desenvolvido por Latour mais radicalmente em outros trabalhos, a sugestão de que é possível conectar fatores externos e internos, ver o mundo, a partir e dentro do laboratório e das práticas científicas ${ }^{13}$. Mas como a credibilidade é avaliada? Fundamentalmente pelos comentários e opiniões dos pares, e nisto as conclusões de Latour e Woolgar não os distinguem de autores como Bourdieu e Kuhn. Mas o que avaliam? Aqui verifica-se uma diferença importante com os outros trabalhos. Nesta apreciação não há distinção entre o cientista e as suas proposições, entre "a credibilidade da proposta e a do proponente" (Latour \& Woolgar, 1979:202). Os cientistas precisam da avaliação para o reinvestimento na sua credibilidade; a preocupação com simples recompensas e reconhecimento seria uma expectativa secundária. Como vimos, em uma ordem competitiva e instável não é suficiente o capital obtido, é preciso convertê-lo, permanentemente e o mais rápido possível, em novas formas de credibilidade do seu trabalho científico e dele enquanto cientista. Credible information reinvestida para gerar mais informação, ou a reprodução para assegurar a reprodução. Em oposição à comunidade científica kuhniana, os autores sugerem que o interesse que o cientista tem pelos seus pares não é oriundo nem do caráter especial dessa comunidade (ela não existe na forma proposta por Kuhn), nem de um "sistema de normas" que faz dos pares os únicos que podem reconhecê-lo - normas são os resultados instáveis dessas interações. Este interesse tem como base uma necessidade recíproca em que cada cientista precisa do outro para "aumentar sua própria produção de credible information" (Latour \& Woolgar, 1979:203). A comunidade de especia-

13 Esse argumento está mais radicalmente exposto em Latour, 1983:141-70. Estudando a revolução "pasteuriana", Latour indica que não basta reconstruir o contexto social dentro do qual a ciência deve ser compreendida, mas mostrar como sociedades são desordenadas e reformadas com e mediante os conteúdos da ciência. No caso, Pasteur operou uma revolução na sociedade francesa no e a partir do laboratório e sem sair dele. Teríamos uma "laboratorização do mundo". Em Science in Action (1987) no cap. 4, Latour também mostra as relações externas operando nos technoscience labs, com os insiders out. 
listas, se existe, se estrutura devido a essa necessidade e interdependência, e não pela solidariedade ou por qualquer monopólio de conhecimentos especiais. Juntos porque interdependentes no ciclo de credibilidade.

A adoção de uma perspectiva que considera o ciclo de credibilidade no âmbito de um laboratório é "espelhada em operações econômicas típicas do capitalismo moderno" , sugere muitas semelhanças com a análise de Bourdieu (Latour \& Woolgar, 1979:204). Porém, Latour e Woolgar o criticam pela utilização de um modelo econômico que não esclarece por que o cientista tem interesse na produção do outro, não considera a demanda pela produção, e não faz nenhuma referência ao conteúdo da ciência produzida. É um modelo, o de Bourdieu, que explica a distribuição do crédito como um sharing process, um problema de acumulação, mas pouco auxilia o entendimento sobre a produção de valor na prática científica.

No mercado científico em questão, a informação produzida por um cientista tem valor porque serve para outros cientistas gerarem novas informações que, por sua vez, facilitarão o retorno dos seus investimentos. O fundamental são as informações e proposições com credibilidade, que, por serem incontestáveis, podem ser reinvestidas. Trata-se de um mercado de informações no qual as forças da oferta e da procura criam o valor da mercadoria, um valor que flutua dependendo da estrutura dessas forças, como, por exemplo, o número de investidores e o equipamento dos produtores e a capacidade atribuída a eles. As flutuações podem levar cientistas a passarem de uma área para outra, ou de certos problemas de pesquisa para outros.

Porém, a experiência do lab life mostra que esse não é um mercado de trocas simples de bens em circulação. O sucesso do investimento é avaliado "em termos da extensão em que é facilitada a rápida conversão da credibilidade e o progresso do cientista dentro do ciclo" (Latour \& Woolgar, 1979:207). Lembram os autores que o cientista obtém pouco retorno do seu investimento em termos de crédito formal, ou pelo menos dá uma importância relativamente pequena a esse fato, já que isto lhe assegura apenas uma parcela de credibilidade. O que importa, nessa atividade, nesse mercado, é ampliar e acelerar o ciclo de credibilidade. Os cientistas não venderiam/comprariam informações, mas sua habilidade em produzir alguma informação relevante no futuro, podendo acelerar a passagem de uma parte do ciclo para outra, tornando assim o futuro mais presente (Latour \& Woolgar, 1979:207).

A análise que Latour e Woolgar fazem da pesquisa que resultou no $\operatorname{TRF}(\mathrm{H})$ demonstra que o capital previamente acumulado pelo grupo de cientistas era pequeno: poucas publicações e citações, e posições acadêmicas sem muita expressão. Eram mais promessas de credibilidade do que detentores de capital acumulado (Latour \& Woolgar, 1979:211). Por isso, esse não é 
um mercado de produtores e consumidores individuais, com uma contabilidade simples, do tipo investimento $x$ rentabilidade. As relações entre cientistas seriam mais semelhantes às que ocorrem entre pequenas empresas que medem seu sucesso pelo crescimento das suas operações e a intensidade na circulação de seu capital. Temos uma análise de custo-benefício aplicada às várias dimensões da atividade científica, das decisões das agências de financiamento à forma do artigo e em que revista publicá-lo. Do não-mercado de Kuhn, passando pelo mercado do empresário individual de Bourdieu, chegamos, com Latour e Woolgar, a um mercado de pequenas empresas.

Um dos problemas dessa interpretação, também encontrado em Bourdieu, é a ausência de uma assunção comportamental. Em algumas passagens, os autores fazem questão de negar que estejam propondo um modelo de comportamento em que indivíduos fazem cálculos para maximizar lucros. E por que não? A resposta a isso não está clara, nem o problema resolvido, como veremos nos trabalhos de Knorr-Cetina. Sustentam os autores que o seu modelo de interpretação do comportamento dos cientistas é completamente independente das suas motivações, e mais, que "o modelo de credibilidade pode acomodar uma variedade de tipos de motivações" (Latour \& Woolgar, 1979:207). Não importa a motivação da ação revelada pelo cientista - dinheiro, glória, reconhecimento, prêmios, citações -, uma vez que cada uma corresponde a um momento de um ciclo de credibilidade que deverá ser completado. Para Latour, não há solução abstrata para o problema de se considerar, ou não, a atividade científica do lab life uma estratégia consciente e explícita por parte do cientista. Para ele, o quanto os cientistas são realmente interessados ou se são determinados pelo campo - mesmo quando pensam ser livres -, é um problema para historiadores e psicólogos (!!!) (Latour \& Woolgar, 1979:208, nota 10).

Ao discutirem a estrutura do grupo de pesquisa e sua dinâmica, os autores têm a oportunidade de relativizar o modelo econômico de base utilitarista, do qual pretendem se afastar, mas acabam por reforçá-lo ao longo de todo o trabaIho, ao ressaltarem a questão da hierarquia interna do grupo. Os técnicos, mesmo que sejam excelentes profissionais, sāo mais simples assalariados que investidores (Latour \& Woolgar, 1979:218). Isso vale igualmente para aqueles que ainda năo possuem um capital de credibilidade a ser invertido e convertido. Os que podem operar como investidores de capital são os líderes do laboratório, menos dispensáveis porque produtores de informações originais e por isso mais valiosas. O principal pesquisador, chefe do laboratório (o chairman), seria o empresário capitalista - full-time investor - que contrata e despede, com técnicos e cientistas trabalhando para ele, podendo ter seu capital acrescido sem estar engajado diretamente na atividade. Sua posição será mantida se continuar fazendo com que 
seu laboratório produza informações consideradas relevantes em áreas importantes, obtendo credibilidade, recursos e colaboração para uma conversão acelerada de um tipo de credibilidade a outro.

Com isso, conclui-se que nem todos podem operar no mercado descrito por Latour e Woolgar, ainda que seja um mercado aberto, e entre os que operam o fazem em condições desiguais. Além disso, os autores indicam, em uma rápida passagem, a armadilha em que estão colocados os cientistas no laboratório dada a sua dupla identidade de investidores de seu capital e de empregados (do governo, de uma instituição privada, da indústria, de seus superiores etc.). De um lado, ele precisa reinvestir seu capital de forma continuada se não quiser perdê-lo; de outro, é pressionado pelo patrão a apresentar os resultados do que fez com os recursos recebidos. Essas pressões, por vezes, implicam dinâmicas irreconciliáveis. As relações entre o laboratório e o mundo não ficam claras, ou melhor, não estão desenvolvidas, apesar de essa proposta metodológica implicar fazer do laboratório o mundo ${ }^{14}$. A proposta de dissolução das fronteiras entre o laboratório e o mundo exterior (inside/outside laboratory walls) continua problemática. Foram ao laboratório e também encontraram o mercado um tanto fechado, ocupado exclusivamente por cientistas que se movimentam em um ciclo de credibilidade.

\section{KNORR-CETINA VAI AO LABORATÓRIO E ENCONTRA A ARENA TRANSEPISTÊMICA}

Os trabalhos de Karin Knorr-Cetina, em especial The Manufacture of Knowledge $(1981 b)^{15}$, na referência importante para todos os chamados estudos de laboratório, pretendem investigar como o conhecimento científico é gerado, no seu lugar específico, o laboratório, dando pouca relevância às razóes pelas quais esse conhecimento é produzido. Assim como Latour - e procuraremos não repetir os argumentos semelhantes -, Knorr-Cetina adere à perspectiva construtivista, que enxerga os produtos da prática científica como "construções contextualmente específicas que têm como característica a situação contingente e a estrutura de interesse do processo pela qual foram geradas" (Knorr-Cetina, 1981b:5). O produto da ciência não pode ser entendido como algo separado das práticas que o constituíram. Esta visão, chamada de interpretação construtivista, também partilha-

14 Em artigo posterior, Latour confessa que as relações e impactos do laboratório sobre o mundo externo são os pontos frágeis de Laboratory Life (Latour, 1983:162).

15 Consideramos importantes dois outros artigos de Knorr-Cetina, que significam algumas reformulações importantes no que se refere ao tema deste trabalho. São: Knorr-Cetina, 1982:101-130 e 1983:115140. As citações serão identificadas pelo ano de publicação do trabalho. 
da por Latour, critica tanto o "objetivismo" que separa o produto do processo de sua produção, focalizando o primeiro, como as perspectivas que buscam identificar quais são os interesses sociais que explicam as escolhas e os trabalhos dos cientistas, mas não elucidam como esses interesses e crenças influenciam no cotidiano da produção do conhecimento científico, e como são negociados pelos cientistas.

Sinteticamente, a interpretação construtivista considera os produtos científicos, fundamentalmente, resultado de um processo de fabricação em um lugar pré-construído, chamado laboratório, expressão máxima do caráter artesanal da realidade científica. Neste espaço de manufatura do conhecimento, verificam-se decisões e escolhas de caráter local e eventual que, ao serem feitas, se materializam de tal forma que condicionam futuras decisões e escolhas. O traço circunstancial de cada decisão na produção científica está impregnado no produto desse processo (Knorr-Cetina, 1981b:33). Para KnorrCetina a produção científica é sempre contextual e contingente.

A autora chama a atenção para o que denomina lógica oportunista da pesquisa científica, que depende dos recursos disponíveis de toda espécie, das chances e das interpretações e idiossincrasias do local onde ocorre. As próprias regras - como fazer - dependem da distribuição de poder dentro do laboratório, que também é contingencial e pode ser rapidamente alterada pela dinâmica do conflito, cujas próprias regras são utilizadas como recurso e negociadas constantemente. Por isso tudo, o cientista atua ajustando-se ao ambiente, utilizando todos os recursos instrumentais disponíveis no seu laboratório, com o objetivo de ser bem-sucedido (making things work), e não de buscar ou descobrir verdades.

A perspectiva de Knorr-Cetina é de que o produto da pesquisa é fabricado e negociado por agentes específicos, em um tempo e espaço particulares, não sendo fruto de uma racionalidade científica especial. Tal concepção pode ser estendida para distintas áreas e utilizada por outros cientistas e laboratórios em diferentes contextos (Knorr-Cetina, 1981b:52). Este é o modo pelo qual o cientista, buscando sucesso, poderia fazer circular um produto científico de um contexto a outro, ampliando e transformando, traduzindo algo de um tempo/espaço específico para um produto mais "universalizado", a ser reconhecido para além dos muros do laboratório; ou, em um movimento oposto, transferir e incorporar no seu trabalho produtos de outras áreas, cientistas e laboratórios.

Não se diferenciando de outros trabalhos sobre/em laboratórios, KnorrCetina sustenta que as descobertas e os produtos científicos são compostos por seleções "contextualmente contingentes", sendo permanentemente descontextualizados e tranformados em inovações/achados/invenções universais nos artigos mediante os quais cientistas comunicam os resultados de seus trabalhos. Essa perspectiva - go and see science as it happens - significaria a restauração do ca- 
ráter contextual da ciência: em vez de paradigmas universais, temos métodos e práticas científicas contingentes e locais, o que faz com que o exercício científico seja não mais que uma das práticas da vida social (Knorr-Cetina, 1981b:46-7).

A diferença entre as análises de Knorr-Cetina e de Latour e Woolgar, e outros trabalhos sobre história e sociologia da ciência, como os de Kuhn e Bourdieu, está na relação entre a manufatura do produto científico e os interesses organizados dentro e fora do laboratório ou como as 'seleções contextuais e contingentes' são sustentadas e atravessadas por relações que a transcendem, isto é, situadas em um campo de relações sociais (Knorr-Cetina, 1981b:68). Os estudos macrossociológicos apontam para a comunidade científica como a unidade relevante da organização social e cognitiva da ciência (Knorr-Cetina, 1981b:68-69). Mesmo em trabalhos em que se nega a existência de uma comunidade científica definida por mecanismos de integração consensual e cooperação entre os seus membros, acabam-se utilizando modelos de interação competitiva que circunscrevem a atividade científica a um foro fechado de especialistas. Ambas as perspectivas não levam em conta a importância das relações entre cientistas e não-cientistas na produção do conhecimento.

A indagação de Knorr-Cetina é clara: depois de muitas observações sobre o caráter contextual e contingente da organização e produção científica, faz sentido continuar a encarar a comunidade científica ou de grupos de especialistas como unidade de análise? A resposta é categórica: os estudos de laboratório indicam a irrelevância da comunidade científica como a unidade organizacional. A explicitação das críticas e a alternativa proposta por Knorr-Cetina são o próximo passo.

A comunidade científica tem sido considerada a unidade organizacional sobre a qual a sociologia da ciência centra as suas atenções. Os estudos de laboratório mostram que a comunidade com base em normas e valores, consensual e cooperativa é uma imagem irreal. A partir de meados dos anos 70, apareceram estudos que tratavam a interação dos cientistas como competitiva, utilizando modelos explicativos baseados no funcionamento da economia de mercado. Do texto pioneiro de Bourdieu ao trabalho de Latour e Woolgar, do crédito à credibilidade, fala-se de capital, riscos, investimentos, reprodução, enfim, lança-se mão de modelos econômicos para a abordagem da atividade científica, sugerindo a existência de um capitalismo científico.

Descartada qualquer idéia de normas e valores como base da organização da ciência e interação dos cientistas, a crítica de Knorr-Cetina concentra-se no que chama de modelos quase-econômicos de ciência, que se apresentam como alternativas ao modelo de comunidade consensual e cooperativa. A crítica é dirigida à concepção simplista de homem econômico presente na economia clássica e que tais modelos assumem: um indivíduo com comportamento racional e maximizador. Este comportamento pode estar vinculado tanto a uma hipótese sobre a natureza humana - apetite insaciável para a acumulação -, como a uma hipótese histórico- 
estrutural - em que este comportamento derivaria dos requisitos exigidos pelo desenvolvimento histórico do mercado capitalista. Para a autora, mesmo as versões mais sofisticadas, que trabalham com decisões sob condições de informação limitada (ou que entende o cálculo racional maximizador como produto de um processo de socialização), ignoram o que as pesquisas sobre laboratórios indicam: que os resultados das decisões são socialmente contextuais ou negociados interativamente. Não procedem de um cálculo consciente ou inconsciente, nem podem ser uma conseqüência de propriedades individuais adquiridas.

Para Knorr-Cetina, todos os modelos de economia capitalista descritivos da comunidade científica estão fundados em uma concepção de homem econômico que por qualquer razão, é racional, calculador e maximizador. Entretanto, esse homo economicus não é observado nos trabalhos sobre o lab life. E mais, para a autora, esses modelos econômicos não foram levados aos seus limites de análise com a inclusão do crescente papel do Estado, da distribuição de renda, da política científica etc. (Knorr-Cetina, 1981b:69). Enfim, não introduzem a complexidade da economia moderna.

Todavia, não é apenas um problema de sofisticação e limites de um modelo analítico de ciência construído por analogia com o mercado econômico, mas do que fazer com essa semelhança. Para Knorr-Cetina, a utilização das analogias significa a tentativa de explicar um fenômeno pouco conhecido mediante o conhecimento derivado de um fenômeno similar, mais bem compreendido (Knorr-Cetina, 1981b:69). Mas não pode ser uma mera troca de termos, como por exemplo, substituir reconhecimento científico por capital simbólico. O conhecimento transferido deve manter sua consistência.

Os modelos de mercado científico acabam por ignorar algumas das características mais importantes do mercado capitalista, como exploração (extração de mais-valia) e a estrutura de classes. Na ausência destas, o modelo perde os seus elementos distintivos. A introdução dos mesmos nos modelos econômicos de ciência obrigaria a aceitação da idéia de apropriação, por alguns cientistas, dos produtos criados por outros, por estarem os primeiros em posições hierarquicamente superiores, possuírem mais capital (simbólico) e controlarem os meios de produção. Para a autora, a posse desse capital simbólico, qualquer que seja a sua definição, é uma característica comum a todos os cientistas, e introduzir distinções desse tipo seria absolutamente arbitrário.

O cientista capitalista, definido por esse critério arbitrário, não controla, necessariamente, os meios de produção científicos. Estes, em geral, "são propriedade não dos cientistas mas de organizações, fundações ou associações que usualmente significa algum controle público ou acesso generalizado a eles" (Knorr-Cetina, 1981:72). Muitos dos esforços dos cientistas são para restringir e definir o uso desses meios de produção. $O$ seu controle hierárquico não significa 
lugar equivalente na hierarquia de prestígio e reconhecimento profissional - nem sempre quem controla é quem se apropria dos produtos científicos produzidos no laboratório. Para a autora, quase todas essas dificuldades originam-se da utilização do conceito de capital simbólico, ou variantes (Knorr-Cetina, 1981b:73).

A crítica que parece ser a mais relevante para a proposta de Knorr-Cetina é a acusação de que a utilização de modelos econômicos na ciência promove uma visão internalista da mesma, apesar de se apresentarem como sendo a sua superação. Esse internalismo, é preciso deixar claro, não é conseqüência da separação entre elementos sociais e cognitivos da ciência, mas sim da insistência em uma perspectiva que limita a ciência aos cientistas. A comunidade científica foi transformada em mercado, com os cientistas, antes colegas, agora produtores e clientes, sendo integrados não por normas, mas pela competição. Os cientistas transformaram-se em capitalistas, mas continuam sendo tratados isoladamente "num sistema auto-contido e quase-independente" formado por pequenos capitalistas ou corporações que se sustentariam "explorando uns aos outros" (KnorrCetina, 1981b:73). Seria um "capitalismo comunitário" que causaria risos aos teóricos da economia, porque aqueles que fornecem os recursos iniciais e permanentes, que permitem a acumulação e reprodução do capital simbólico, estão ausentes do modelo de mercado científico. Este modelo continua a circunscrever a análise aos cientistas, reproduzindo de um modo mais sofisticado a comunidade científica fechada e auto-referenciada que procurou criticar.

Por último, o limite que restringe a análise aos cientistas e relaciona a informação produzida, que transformada em fatos - o principal objetivo do cientista é seu acesso a posições, carreira, dinheiro, reconhecimento -, torna o argumento circular e funcional. A credible information permite o investimento nesses recursos que, por sua vez, serão reinvestidos para gerar mais informação. A posição do cientista é definida pela capacidade de produzir e reinvestir informações que tenham status de fato. Isto não parece ser o que acontece no mundo do laboratório observado por Knorr-Cetina.

A proposta da autora é superar a noção tradicional de comunidade científica e os modelos de mercado científico que se baseiam em visōes simplistas do comportamento humano, reforçam perspectivas internalistas de ciência e terminam com argumentos circulares e funcionais. Como? Mediante o que denomina de perspectiva radically-centred das coletividades científicas e de suas práticas contextuais e contingentes (Knorr-Cetina, 1983:132). A conclusão de Knorr-Cetina é que as comunidades científicas são praticamente irrelevantes para quem trabalha no laboratório. A forma de organização relevante e a interação dos agentes na produção do conhecimento científico devem ser verificadas nas percepções dos participantes dessa produção no seu contexto específico, o laboratório, e não por caracte- 
rísticas a eles atribuídas. A forma organizacional e interativa relevante da prática científica deve ser verificada empiricamente, a partir da observação do cotidiano das práticas científicas nos laboratórios, podendo variar em contextos diversos.

A perspectiva da autora é derivar conceitos de estrutura social a partir de análises dos microeventos. Inclusive ela não descarta a utilidade da noção de comunidade nas abordagens macrossociológicas da ciência. O que aconteceria é que "procedimentos agregados tendem a negligenciar - e como conseqüência distorcer - os envolvimentos e o raciocínio práticos dos agentes" (Knorr-Cetina, 1982:116). Para não se constituírem meras reificações, as proposições sobre estruturas sociais (e científicas) devem ter referência empírica por meio da observação das microações que geram essas estruturas. E, agora, podemos introduzir a alternativa proposta por Knorr-Cetina: os campos transcientíficos ou arenas transepistêmicas ${ }^{16}$.

O trabalho científico é perpassado e sustentado por relações e atividades que transcendem o laboratório. Os cientistas percebem-se envolvidos e confrontados em arenas de ação que são transepistêmicas por envolverem "uma combinação de pessoas e argumentos" que não podem ser classificadas nem como "puramente" científica nem como não-científica (Knorr-Cetina, 1982:117). Essas arenas incluem agências de financiamento, administradores, indústrias, editores, diretores de instituições científicas, fornecedores, enfim, uma série de elementos que pouco têm a ver com um grupo de especialistas. Elas são transcientíficas ou transepistêmica porque também os cientistas estão envolvidos em trocas, desempenhando também papéis não-científicos como administradores e negociadores de recursos, com implicações técnicas importantes para o trabalho de pesquisa. As relações entre cientistas e não-cientistas não estão limitadas à transferência de todo tipo de recurso. Implicam escolhas e decisões técnicas, em que métodos e interpretações são negociados com representantes das agências financiadoras e de indústrias fornecedoras de produtos para o laboratório. O caráter transepistêmico está na necessidade de tradução, que é uma negociação entre diferentes agentes sobre os problemas da pesquisa, como ele pode ser solucionado e avaliado. A autora assume que escolhas técnicas não são determinadas exclusivamente por cientistas e, por isso, não vê sentido em se reinvindicar que a comunidade científica seja considerada a unidade relevante de produção do conhecimento (KnorrCetina, 1981b:82). As arenas transepistêmicas são constituídas, dissolvidas e reconstituídas cotidianamente na atividade científica contextualizada, implicando jogos interativos entre os vários agentes que dela participam. E o que está em questão não é o que se compartilha ou o que se possui, mas o que pode ser transmitido pelos

16 A expressão campos transcientíficos está no livro de 1981. Nos artigos de 1982 e 1983, Knorr-Cetina reelabora a expressão passando a utilizar o termo arenas transepistêmicas. Os termos no plural indicam as variações contextuais e contingenciais da sua análise. 
agentes para ser utilizado pelos outros para converter em outras coisas. Essa arena não seria nada mais que "a soma das interrelações que um sociólogo que adota uma perspectiva birds-eye pode reconstruir a partir da representação que os agentes fazem de seus envolvimentos mútuos" (Knorr-Cetina, 1982:119).

A interação dos agentes nesta arena é vista por Knorr-Cetina como relações de dependência mútua em termos de recursos e suporte (Knorr-Cetina, 1982:119). Essas relações não são concebidas a partir de objetivos individuais dos participantes, cientistas e não-cientistas, que a priori têm interesses e recursos, mas transações contínuas e contextualizadas, nas quais o próprio interesse é fruto de negociação, que pode oscilar entre conflito e cooperação. $O$ que é recurso, e não apenas conhecimento, é também definido na interação, e o que se busca é a estabilização dessa definição, que implica que essas relações devem ser continuamente renovadas e expandidas para sobreviver. Teríamos, segundo Knorr-Cetina, uma economia de mudança e conversão (change) em vez de uma economia de trocas (exchange) postulada pelos autores por ela criticados. A circulação de objetos nessa economia de conversão não se faz pela troca de equivalentes, mas por uma conversão negociada de objetos diferentes. Apesar de crítica dos autores anteriormente analisados, Knorr-Cetina parece-me pouco reflexiva, no sentido de Bloor e mesmo no de Latour, já que a sua alternativa aos modelos de mercado científico guarda muitas semelhanças com os mesmos, e caindo até mesmo nos equívocos que ela aponta, como a substituição de termos sem esclarecer bem o que realmente muda, por exemplo, entre a economy of exchange para a sua economy of change.

De qualquer forma, e finalizando, deve-se ressaltar que a importância dada pela autora para a arena transepistêmica indica que os envolvimentos dos cientistas são partes intrínsecas da produção de conhecimento no laboratório, tratando-se de algo muito mais complexo que falar sobre as definições externa ou interna do problema de pesquisa. Nessa arena, o trabalho científico é definido e redefinido pelas interações de epistemes diversas. Enfim, para Knorr-Cetina são os estudos sobre as práticas internas à produção científica em laboratórios, na perspectiva microssociológica, que podem rejeitar o internalismo embutido nos conceitos de comunidade, campo e mercado científico.

\section{CONSIDERAÇÕES FINAIS}

Sem querermos repetir todas as críticas que apareceram ao longo deste trabaTho, devemos ressaltar que, para os autores discutidos, os cientistas se organizam e interagem de maneiras diversas. Comunidade científica, campo científico, ciclo de credibilidade, arena transepistêmica são concepçōes diferentes sobre a dinâmica or- 
ganizacional e interativa da prática científica. Para Kuhn, o cientista agirá segundo as normas e valores da comunidade; para os demais, perseguindo seus mais variados interesses e objetivos individuais, mesmo que não os alcancem.

A comunidade científica é autônoma, fundada no consenso, estável e tem, como comunidade, uma finalidade última. No campo científico, um mercado científico, também um lugar autonomizado, a dinâmica da competição, do conflito por crédito, encontra-se condicionada pela estrutura social, onde o "progresso da razão" resulta da competição por acumulação e reprodução de capital simbólico. Quando alguns autores vão ao laboratório ver como funciona a ciência normal encontram uma organização da prática científica mais dinâmica, mais competitiva e plural, instável, na qual indivíduos concorrem pela produção de informações relevantes, que serão convertidas ou modificadas. Uma competição cujo resultado é, sempre, indeterminado. A autoridade científica que em Kuhn encontra um lugar determinado para Bourdieu, Latour e Knorr-Cetina é resultado da interação competitiva - para Bourdieu este resultado, senão completamente determinado pela estrutura social, é fortemente condicionado por ela.

Quanto mais perto do local da prática científica, o laboratório, mais dinâmica, mais instável, mais indeterminada e menos consensual é a interação e a organização dos cientistas. O mundo da ciência vai se tornando mais aberto ao exterior, o mercado científico vai aparecendo e o lugar do indivíduo aumentando, quanto mais os analistas se aproximam da intimidade dos cientistas. As fronteiras entre o mundo exterior e o dos praticantes da ciência vão, assim, sendo diluídas até surgir a àrena transepistêmica, onde o produto da ciência não é o resultado da ação autônoma e isolada dos cientistas.

As escolhas, feitas por todos, das ciências naturais e exatas para serem o foco de suas análises, têm diferentes razōes de ser em virtude das opções teórico-metodológicas. Para Kuhn, as ciências naturais e exatas alcançaram um amadurecimento, não obtido pelas ciências sociais, que pode ser constatado pela presença hegemônica de um paradigma. Portanto, a sua comunidade científica é a das ciências exatas e naturais. Para Bourdieu, a diferença entre as ciências sociais e as naturais está nas expectativas e nos interesses que as classes dominantes têm sobre estas últimas para o processo produtivo, garantindo assim a autonomização do campo científico nestas áreas. Para Latour, Woolgar e Knorr-Cetina, a escolha das ciências naturais e da technoscience para o estudo etnográfico serve para demonstrar não a superioridade de ambas, mas o quanto são semelhantes às ciências sociais. Em todas as ciências, temos práticas por meio das quais o conhecimento é fabricado. Tão caóticas, incertas e complicadas como as práticas das ciências sociais são as das ciências ditas exatas e naturais.

Antes de prosseguir, gostaria de chamar a atenção para um ponto: é que se nem todos esquecem do Estado como agente importante, quando o abordam, 
como Latour, o fazem como fonte financiadora dentro do ciclo de credibilidade, ou como Knorr-Cetina, com o representante da agência pública de financiamento, negociando resultados e maneiras de fazer pesquisa com o cientista. $O$ Estado, ou governo, como instância reguladora da propriedade intelectual - por exemplo, através da regulamentação e concesso de patentes - não aparece como fator relevante na organização e interação de cientistas. Descobertas, invenções, competição, crédito, credibilidade, proposições que se tornam fatos, tudo isso faz mais sentido se lembrarmos a existência de uma regulamentação estatal que permite que um produto ou informação - em vez de simplesmente ser imposto ao mercado, circular livremente no mercado e ser apropriado por outros cientistas - se torne uma propriedade do autor via concessão de patente, enfim, um valor de troca. Se isso não tem lugar na abordagem de Kuhn, certamente resolveria alguns problemas nas análises de Bourdieu, Latour e Knorr-Cetina. As perspectivas que discorrem sobre capital, conversão, troca e investimento da informação, se tornariam mais efetivas se explicitassem a questão da regulamentação da propriedade intelectual ${ }^{17}$.

Dado esse inventário de diferenças e problemas, talvez estejamos diante de enfoques distintos de diferentes dimensões da sociedade, ou, no caso, das práticas científicas, e não apenas da escolha entre a comunidade do pensamento conservador e o mercado da economia liberal. $\mathrm{O}$ instigante enfoque de David Bloor, ${ }^{18}$ relacionando o debate epistemológico entre Kuhn e Popper - como expressão de concepções ideológicas que estão presentes, enraizadas, na cultura ocidental, o romantismo e a ilustração -, poderia, e certamente deve ser aplicado às opções metodológicas e conceituais dos autores em questão. Porém, cremos que, para além da identificação das conexóes entre os debates ideológicos e as opções dos autores, estamos diante de abordagens que se preocupam com dimensões analíticas diferentes mais do que com opções irreconciliáveis, ou, utilizando um termo da sociologia da ciência, incomensuráveis.

Vejamos. De um lado temos Kuhn e Bourdieu, com todas as suas diferenças, trabalhando com macroestruturas (comunidade e mercado); de outro, Latour, Woolgar e Knorr-Cetina, com microprocessos de interação em um local específico, o laboratório. $O$ resultado da interação dos agentes no mercado de Bourdieu é, em grande parte, determinado ex-ante pela sociedade, ao passo que no mercado científico de Latour e Knorr-Cetina, o resultado só é observável

17 Estamos cometendo uma certa injustiça com Latour, que desenvolve esse tema na análise das relações do laboratório com a indústria em Science in Action (1987), caps. 3 e 4, e faz referências a isso em Laboratory Life (1979), cap. 5. A questão é que essas indicaçōes não têm muitas consequiências, por exemplo, para um dos seus principais argumentos: o ciclo de credibilidade. 
quando da interação. O lugar para a ação humana é pouco relevante em Kuhn e Bourdieu, já para os demais é a base de geração das estruturas sociais. Normas e valores organizam as práticas científicas da comunidade kuhniana.

Bourdieu escreve sobre interesses, mas recorre ao aprendizado para explicá-los estruturalmente; com Knorr-Cetina e Latour, os cientistas têm interesses, quais seriam esses interesses é uma questão de verificação empírica. Sugerimos, mesmo sem desenvolver, que, apesar de ao longo do texto, e logo acima, termos mostrado uma série de divergências irreconciliáveis entre os autores, haveria um maior rendimento na análise sociológica da ciência se recolocássemos essas diferenças no âmbito do debate tradicional da sociologia, ıntre agência e estrutura, e de uma maneira mais geral, entre macro e microssociologia.

Para Latour e Knorr-Cetina, a meta é obsenvar as práticas científicas no seu lugar privilegiado, mostrando um universo diferente daquele que é percebido pelas análises macroestruturais. Os estudos de laboratório não são apenas micro, sem influências externas, mas têm a virtude distintiva, como lembra Woolgar, "de ser capaz de manejar problemas de 'macro' importância usando 'materiais micro' $^{\prime \prime} .{ }^{19} \mathrm{O}$ objetivo não é apenas descobrir que o mundo da ciência não é aquele descrito por alguns sociólogos e filósofos, e que é semelhante ao mundo nãocientífico, mas os estudos de laboratório pretendem ser estudos "no (in) laboratório e não apenas sobre um (of a) laboratório". ${ }^{20}$ Nele encontraremos o mundo, segundo Latour, adepto mais radical da perspectiva micro, o que significa dizer que não é possível uma divisão de trabalho ou uma tradução da microanálise para a macroanálise. A prática científica só deve ser analisada no laboratório. Para Knorr-Cetina, o estudo de laboratório permite observar a emergência das macroestruturas sociais, ou a sua reconstrução a partir da interação dos agentes ${ }^{21}$. Isto não quer dizer que essas grandes estruturas não possam ser analisadas de uma outra maneira, inclusive a própria noção de comunidade pode fazer sentido analítico em uma dimensão macrossocial, como nas perspectivas de Kuhn e Bourdieu.

Um sociólogo como Randall Collins $(1988)^{22}$, ao analisar as teorias micro e macrossociológicas e a possibilidade de uma tradução e ligação entre elas - um tanto cético em face da redução ou tradução da macro em micro -, propõe tratar das teorias macro (e das relações com as microteorias) a partir do que chama de fatores irredutiveis desse tipo de análise: a) extensão espacial; b) extensão do tempo e c) número de pessoas envolvidas (Collins, 1988:394).

19 Woolgar, 1982:490

20 Woolgar, 1982:487

21 A autora explicita melhor a sua concepção das relações micro e macrossociologias em: KnorrCetina, 1981:1-47.

22 As citações referem-se ao capítulo 11. 
Ao declarar a irredutibilidade desses fatores, ele chama a atenção para características intrínsecas da análise macro. Tempo e espaço seriam escalas da análise sociológica e quanto maiores essas dimensões mais macro seria a análise. Porém, o autor destaca a precedência da abordagem macro sobre a micro: dadas certas irredutibilidades "situações micro são analiticamente centrais, mas o conteúdo presente das microssituações é afetado pela sua posição macro" ou, talvez, de forma mais interessante, macro seria o meio pelo qual as microssituações se conectariam (Collins, 1988:397). A sugestão proposta por Collins, via diferenciação de escalas (tempo, espaço e número), é uma possível combinação, redução ou tradução de análises que se preocupam com grandes escalas (macro) e aquelas que trabalham com escalas menores (micro). Este pode ser um dos caminhos para relacionarmos as abordagens em questão, sem negar uma certa taxa de incomensurabilidade entre elas.

Para finalizar, gostaríamos de sugerir que, em lugar de opções incompatíveis-comunidade, campo, mercado, arena - possam significar respostas a problemas colocados em diferentes escalas, e que podem ter bons rendimentos analíticos se estiver explícito em que dimensão cada autor trabalha ${ }^{23}$. Comunidade, campo, mercado, arena implicam em diferenças que podem ser traduzíveis dentro das relações entre micro e macrossociologia.

Enfim, se continuamos a ser colocados entre a comunidade e o mercado, é porque também continuamos tão curiosos e perplexos quanto Jonathan, o pai de Adrian Leverkühn, o músico que pactua com Mephistófeles no Doutor Fausto de Thomas Mann, que buscava decifrar inscrições que apareciam nas conchas e moluscos que colecionava. Para ele, essas inscrições eram parte de uma escrita, uma linguagem secreta da natureza. E Jonathan achava que "se (...) houvesse uma escrita secreta, a Natureza teria de dispor de um idioma próprio, organizado, nascido dela mesma? Pois qual dentre os inventados pelo homem deveria ela escolher para exprimir-se?". O narrador do livro termina dizendo que há muito tempo percebia que o que confere à natureza extra-humana um caráter inquietante é que ela é, por índole, iletrada ...

23 Inspirei-me, sem necessariamente concordar, em alguns argumentos levantados ao longo de uma dura crítica ao relativismo e ao construtivismo feita por Thomas F. Gieryn, 1982:279-97. Nesta revista, temos a resposta dos relativistas e construtivistas e a réplica de Gieryn. Esta ressalta que, apesar da proposta dita renovadora dessas perspectivas, que pretendem ultrapassar e enterrar a sociologia do conhecimento mertoniana, as suas questões continuariam sendo as de Merton, e as suas respostas também estariam, pelo menos esboçadas, em Metron. Restando, em termos de originalidade, segundo o autor, uma duvidosa opção metodológica que aponta para o monopólio do laboratório como lugar mais importante para a observação da ciência. Consideramos um argumento interessante o de situar os problemas levantados por essas perspectivas, como questões da sociologia da ciência como um todo, podendo ser respondidos com metodologias, enfoques e trabalhos diversificados. 


\title{
Fleck e a Historiografia Recente da Pesquisa Biomédica
}

\author{
Ilana Löwy
}

Tradução do original em inglês de Gilda Gomes Carneiro Revisão técnica de Vera Portocarrero

\section{HISTORIADORES, SOCIÓLOGOS E LABORATÓRIOS BIOMÉDICOS}

$\mathrm{H}$ istoriadores (e médicos) concordam que a aliança entre as ciências de laboratório (química, histologia, bacteriologia) e a 'medicina de beira de leito' desempenharam um papel importante na transformação radical do conhecimento médico e da medicina nos séculos $\mathrm{XIX}$ e XX $\mathrm{X}^{1}$. O consenso quanto à importância do laboratório, no entanto, não se direcionou necessariamente para o interesse pelos laboratórios médicos e biomédicos. Os historiadores da medicina têm-se interessado pelo conhecimento produzido no laboratório e sua influência na(s) prática(s) médica(s), porém raramente estudam os laboratórios biomédicos. Isto é válido tanto para as abordagens tradicionais da história da medicina, que estudam antigos textos médicos e grandes médicos do passado, quanto para algumas das mais novas tendências na história da medicina. Um número significativo de historiadores da medicina desenvolveu, nos últimos 20 anos, um forte interesse pela medicina como prática social e política e como fenômeno cultural. A mudança de direcionamento das pesquisas para os aspectos sociais, políticos e culturais ampliou o campo de investigação de numerosos historiadores. Contudo, muitas vezes, afastou suas preocupações de aspectos como o desenvolvimento e a difusão do conhecimento médico ou das práticas profissionais dos médicos e dos cientistas biomédicos (Leawitt, 1990; Brandt, 1991).

1 Vogel \& Rosenberg, 1979; Pickstone, 1992; Löwy, 1993. 
O interesse pelos laboratórios biomédicos surgiu de uma direção diferente: novas perspectivas nos 'estudos da ciência' (história, filosofia e sociologia da ciência). A partir dos anos 70, 'etnógrafos do laboratório' começaram a observar as práticas experimentais (as quais, na ciência moderna, localizam-se freqüente, senão exclusivamente, em laboratórios). Seus estudos atraíram a atenção de tópicos como a formação de conhecimento local e contingente, a importância da aquisição e transmissão de habilidades específicas, o papel das inscrições, e a impossibilidade de codificar - conseqüentemente de analisar e transcrever - a totalidade das tarefas dos cientistas. Vários dentre os novos 'etnógrafos do laboratório' observaram laboratórios biológicos, bioquímicos ou fisiológicos ${ }^{2}$. Seus estudos consideravam os laboratórios biomédicos como representando a entidade geral 'laboratório de ciência', não como um local específico de afirmação de conhecimento ou de práticas. Eles permitiram, no entanto, a constituição de um corpo de observações das práticas dos cientistas biomédicos.

Quase ao mesmo tempo, os laboratórios tornaram-se interessante objeto de estudo para os historiadores da ciência. ${ }^{3}$ Os historiadores da ciência 'pósKuhnianos' (e 'pós-Polanyianos') ${ }^{4}$ investigaram experimentos e voltaram-se para objetos tais como o estudo de inscrições (notas de laboratório, projetos de pesquisa, representações gráficas, desenhos e fotografias), instrumentos científicos, instrumentos de aferição, técnicas de calibragem e padronização, transmissão de conhecimento e de habilidades tácitos e de culturas laboratoriais. ${ }^{5} \mathrm{O}$ interesse pelas práticas experimentais e laboratoriais estendeu-se, também, aos filósofos da ciência. ${ }^{6} \mathrm{O}$ estudo das práticas experimentais, antigas e atuais, tornou-se um dos tópicos centrais dos "estudos da ciência" na década de 80 (Pickering, 1992a). Tais estudos têm como meta a compreensão integrada de todos os aspectos do fazer ciência: planejamento e processamento dos experimentos, instrumentos de construção, configuração dos instrumentos de pesquisa, quantificação e transcrição dos resultados, elaboração das teorias, negociação com os provedores, debates com colegas, estabilização do conhecimento. O estudo de laboratórios é vital para tal entendimento.

2 Por exemplo: Latour \& Woolgar, 1979; Knorr Cetina, 1981; Star, 1983; Lynch, 1985.

3 Alguns historiadores da ciência tradicionais interessaram-se por experimentos e estudaram fontes tais como notas de laboratório. Conferir Holmes, F. L. (1992), pp 119-136. Estes estudos não foram, todavia, centrados na ciência como prática.

4 Polanyi, 1958; Kuhn, 1962.

5 Por exemplo: Galison, 1987; Holmes, 1987; Gooding, Pinch \& Scheffer, 1989; Starr, 1989; Gooding, 1989.

6 Por exemplo: Hacking, 1983; Catwright, 1983. 
Discutem-se aqui, algumas destas recentes historiografias de laboratórios biomédicos. A organização do trabalho nestes laboratórios é semelhante àquela em outros laboratórios de pesquisa. O destino dos 'produtos' elaborados em laboratórios biomédicos pode, entretanto, ser diferente. Os laboratórios, que visam à produção de conhecimento privilegiando a medicina, desenvolvem produtos (conhecimento, ferramentas, reagentes) destinados à circulação nos distintos e heterogêneos 'mundos sociais' ${ }^{7}$ dos profissionais médicos, pacientes e administradores da saúde. A pesquisa biomédica freqüentemente combina uma forte auto-imagem da ciência fundamental com uma ligação com a prática médica igualmente forte. É legitimada simultaneamente pela sua contribuição para a compreensão fundamental dos fenômenos da vida e para a solução de problemas práticos de deteç̧ão, cura e prevenção de doenças. Esta dupla legitimação aumenta a necessidade de articulações bem-sucedidas entre o mundo da pesquisa biomédica e os 'mundos sociais' externos. Os estudiosos dos laboratórios biomédicos modernos freqüentemente esbarram em tais articulações, e, cada vez mais, as incluem em suas investigações. ${ }^{8}$ Um historiador ou sociólogo, obrigado a lidar com as complexas interações de um laboratório biomédico com outros 'mundos sociais', pode, ocasionalmente, invejar os colegas que estudam campos mais auto-referidos. Por outro lado, o esforço para compreender o complicado mundo de um laboratório biomédico pode, talvez, ser responsável por algumas das contribuições originais destes estudos para o domínio das investigações científicas e práticas técnicas, assim como para a compreensão da 'complexidade essencial' ${ }^{9}$ da ciência moderna.

A primeira parte deste trabalho discute a primeira 'historiografia da pesquisa biomédica' - as reflexões de Ludwik Fleck fundamentadas na 'gênese e desenvolvimento dos fatos científicos em um laboratório biomédico'. Fleck escreveu seus principais estudos há mais de um século, mas seu trabalho, acreditamos, ainda pode dar orientações frutíferas para historiadores e sociólogos. A segunda parte deste trabalho segue vários estudos

7 Utilizamos o termo 'mundo social' estritamente no sentido a ele atribuído por Angela Strauss (1982).

8 A ciência moderna é um empreendimento coletivo com importantes ramificações sociais e políticas. Até mesmo as comunidades experimentais mais fechadas como, por exemplo, a comunidade de físicos da high energy descrita por Sharon Traveek (1988), depende de administradores e políticos para a obtenção de recursos para seus estudos. O grau de dependência das comunidades científicas em colaboração com outros grupos varia e a comunidade de cientistas biomédicos possui um grau de isolamento do mundo externo relativamente baixo (Porter, 1991).

9 A expressão foi emprestada de Gaston Bachelard, 1987:5. 
recentes de laboratórios biomédicos e focaliza, sob diferentes abordagens, a estabilização e a difusão do conhecimento e das práticas originadas em laboratório. Na conclusāo, resgatamos as duas partes anteriores para apresentar as ferramentas conceituais que podem ser aplicadas aos estudos do complexo mundo da pesquisa biomédica moderna.

\section{FLECK E A HISTORIOGRAFIA DO LABORATÓRIO BIOMÉDICO NOS ANOS 30}

Ludwik Fleck (1896-1961), bacteriologista e imunologista de origem judaicopolonesa, desenvolveu, nos anos 20 e 30, um grande interesse pela história e filosofia da ciência. É hoje considerado o pioneiro da abordagem sociológica no estudo do conhecimento científico, das comunidades científicas e das práticas dos cientistas. ${ }^{10} \mathrm{O}$ principal trabalho teórico de Fleck, Gênese e Desenvolvimento de um Fato Científico (1935), estuda um 'fato' produzido em um laboratório biomédico: o desenvolvimento da reação de Wassermann para a detecção da sífilis. Fleck afirma que a reação de Wassermann não foi 'descoberta' apenas por um cientista, ou por um pequeno grupo deles, mas foi o produto de um esforço coletivo da comunidade de serologistas; além disso, foi moldada pelas múltiplas interações desta comunidade com outros grupos sociais (pacientes, clínicos gerais, políticos).

A abordagem teórica de Fleck, conforme apresentamos em outro trabaTho, inspirou-se no pensamento orientado pela prática da Escola Polonesa de Filosofia e Medicina, ao passo que sua epistemologia se fundamentou em sua prática como bacteriologista e imunologista. ${ }^{11}$ Fleck enfatizou repetidamente a necessidade de fundar as reflexōes sobre a ciência numa observação detalhada das atividades cotidianas dos cientistas, "pois, uma epistemologia sem uma história das pesquisas comparativas não é mais que um jogo de palavras vazio ou uma epistemologia da imaginação" (Fleck, 1979:21). O primeiro estudo epistemológico de Fleck afirmava que as 'doenças' são construções coletivas dos médicos (Fleck, 1986a:39-46). No seu segundo trabalho epistemológico, ele radicalizou esta idéia e explicou que os agentes causadores das doenças (infecciosas), as bactérias, são também construções dos cientistas (Fleck, 1986b:47 56). Este ponto de vista enraizou-se na experiência profissional de Fleck como bacteriologista. A classificação de uma bactéria, explicava, pode depender do objetivo de uma dada investigação. Por exemplo, os bioquímicos que estudaram a bactéria Streptococcus haemolyticus deram uma definição restritiva desta espécie, porque

10 Kuhn, T S, "Foreword". In: Fleck, L. Genesis and Development of Scientifc Fact, Chicago, University of Chicago Press, pp VII-XIV. (Versão original: Fleck, L. (1935), Entstehung und Entwicklung einer Wissenschlaftlichen: Einführung in die Lehre vom Denkskill und Denkkollektiv. Basel, Bruno Schwabe; Barnes \& Edge, 1983:65; Cohen \& Schnelle, 1986a: IX -XXXIII.

11 Löwy, 1986, 1988 e 1990; Freudenthal \& Löwy, 1988. 
eles queriam limitar os resultados 'falso positivos' e ter a garantia de que cada colônia estudada demonstrasse claramente as características destas bactérias. Ao contrário, os epidemiologistas forneceram uma definição ampliada do Streptococcus haemolyticus, porque seu objetivo era limitar os resultados 'falso-negativos' que poderiam retardar o reconhecimento dos perigos para a saúde pública. Uma bactéria que apresentasse algumas, mas não todas, as características do $S$. haemolyticus seria, portanto, classificada nestas espécies pelos epidemiologistas, e delas seria excluída pelos bioquímicos (Fleck, 1986b:52) ${ }^{12}$. As definições da espécie S.haemolyticos dos bioquímicos e dos epidemiologistas, foram, por conseguinte, moldadas por suas respectivas - e incomensuráveis - práticas profissionais. Conseqüentemente, o $\mathrm{S}$. haemolyticus do bioquímico e o S.haemolyticus do epidemiologista são entidades incomensuráveis. ${ }^{13}$

Posteriormente, em seu livro de 1935, Gênese e Desenvolvimento de um Fato Científico e em artigos escritos na mesma época, Fleck desenvolve a idéia sobre o papel das práticas profissionais na construção e validação dos 'fatos científicos'. O conhecimento, explica ele, não pode ser concebido fora do grupo de pessoas que o criam e o possuem. Um fato científico é como uma regra desenvolvida por um pensamento coletivo, isto é, um grupo de pessoas ligadas por um estilo de pensamento comum. O conceito de estilo de pensamento tenta abranger tanto os pressupostos a partir dos quais o grupo constrói seu estoque específico de conhecimento, quanto sua unidade conceitual e prática. Um estilo de pensamento formula não só o conhecimento que é considerado como garantido por um pensamento coletivo dado, mas também seu corpo de práticas: métodos e ferramentas usados no exame da evidência e critérios para julgar seus resultados. Ele define o que deve ser considerado como um problema científico e como lidar com este problema. $O$ estilo de pensamento de uma dada comunidade de cientistas molda, portanto, os 'fatos científicos' (conceitos, objetos ou métodos) produzidos por esta comunidade (Fleck, 1979:84-85; Cohen \& Schnelle, 1986a:XX).

Os fenômenos experimentais (como a variabilidade das bactérias) são produzidos, explica Fleck, pelas práticas de laboratório. A bacteriologia médica foi desenvolvida com base no pressuposto de que as doenças infecciosas são entidades distintas, cada uma delas induzida por uma bactéria específica, e de que estas bactérias constituem espécies estáveis e fixas (o assim chamado 'dogma Koch Cohn'). A crença na fixidez da espécie bacteriológica estabilizou-se através da rigidez dos métodos de trabalho no laboratório bacteriológico, em fins do século XIX:

12 Fleck baseia seu arrazoado no artigo do Prof. Elke no Klinische Wochenschrift, 1928, 48, 2280, que relatou achados contraditórios sobre a frequência do Streptococus haemolyticus nas gargantas de pacientes que sofriam de escarlatina.

13 Incomensurável, pode-se dizer num sentido quase literal: o $S$. Haemolyticus do epidemiologista e o $S$. haemolyticus do bioquímico não são medidos da mesma maneira. 
Apenas um método estritamente ortodoxo era reconhecido e os descobrimentos eram, conseqüentemente, muito restritos e uniformes. Por exemplo, as culturas eram reinoculadas geralmente somente por vinte e quatro horas. As culturas muito novas (duas ou três horas) ou as muito velhas não eram sequer consideradas válidas para exame. Como resultado, todas as mudanças secundárias nas culturas, que foram (posteriormente) o ponto de partida para o novo estilo da teoria da variabilidade, não eram alvo de atenção. $O$ que quer que não estivesse em conformidade total com o esquema padrão era olhado como uma "forma de involução", um tipo de fenômeno patológico, ou como uma modificação "artificial" causada por condições externas. A harmonia da ilusão estava assim preservada. As espécies eram fixas porque um método fixo e rígido foi aplicado à investigação. $O$ estilo de pensamento, assim desenvolvido, tornou possível a percepção de diversas formas, assim como o estabelecimento de muitos fatos aplicáveis. Mas também representou o reconhecimento de outras formas e outros fatos impossíveis (Fleck, 1979:93). ${ }^{14}$

Fleck acreditava que os cientistas que pertencem a diferentes grupos passam por um longo processo de socialização no estilo de pensamento de sua comunidade. Este processo inclui a internalização das normas e dos valores da comunidade e a aquisição de habilidades específicas (que incluem a capacidade de perceber fenômenos específicos) (Fleck, 1986c:60-61 e 1979:110-111). O processo de socialização dos cientistas em um dado estilo de pensamento pode ser responsável pela estabilidade relativa dos grupos de pensamento e dos estilos de pensamento: pode, também, explicar a incomensurabilidade dos 'fatos científicos' gerados pelas diferentes comunidades científicas. A ciência moderna não é composta, contudo, por grupos pequenos e hermeticamente fechados que produzem 'fatos' destinados para seu uso exclusivo. A verdade é exatamente o oposto: os cientistas freqüentemente interagem com especialistas de outros campos, e com outros grupos sociais (administradores, políticos, o público leigo), ao passo que os 'fatos científicos' produzidos por uma dada comunidade científica são utilizados por outros grupos científicos e não-científicos. $O$ estudo das interações entre grupos de pensamento e da circulação dos 'fatos científicos' é um ponto central das refle-

14 Fleck nota que quando Neisser e Massini modificaram um único detalhe no procedimento rígido e examinaram a cultura novamente após diversos dias, eles podiam observar a variabilidade (1986). Sobre a variabilidade da bactéria, ver: Hadley, 1927; Amsterdamska, 1987. 
xões de Fleck sobre "a gênese e o desenvolvimento" da reação de Wassermann. O teste elaborado no laboratório de Wassermann, nos anos 1906-1907, tinha uma baixa especificidade e era difícil de ser reproduzido. Além disso, sua fundamentação científica era pouco compreendida ${ }^{15}$. Estes obstáculos iniciais foram superados graças ao esforço coletivo da comunidade de serologistas. Em meados de 1930, o teste Wassermann era considerado um 'fato científico' estável, suficientemente seguro para ser utilizado não apenas para a confirmação do diagnóstico da sífilis em casos suspeitos, como também para a proteção, em larga escala, das populações sadias (testes pré-nupciais obrigatórios, proteção dos soldados) (Fleck, 1979:7081; Brant, 1986:147-152). A transformação da reação Wassermann, que era um fenômeno frágil, produzido localmente, em um 'fato científico' estável e amplamente difundido foi possivel graças ao impressionante esforço coletivo de padronização e calibragem desta reação, transmitido através de uma rede de conferências e seminários internacionais (Fleck, 1979:53; Vogelsang, 1940:26-30). Este processo conferiu uma estabilidade, simultaneamente, tanto ao método (a reação Wassermann) quanto a seu 'produto' (a equação individual Wassermann positivo $=$ pessoa infectada pelo Treponema pallidum) ${ }^{16}$. Foi também fundamental para o desenvolvimento de uma nova subespecialidade biomédica - a serologia ${ }^{17}$.

O desenvolvimento de um teste sangüíneo para o diagnóstico da sífilis interessou não apenas ao 'pensamento coletivo', que produziu esta reação -, dos serologistas -, mas a outros grupos sociais também: médicos especializados no tratamento de doenças venéreas, clínicos gerais, epidemiologistas, autoridades da saúde pública, pacientes e suas famílias. Fleck afirmava que a conjunção de idéias científicas (a especificidade do soro anticorpo), crenças populares (a existência do 'sangue sifilítico') e considerações políticas (a importância atribuída ao desenvolvimento de um teste confiável de diagnóstico da sífilis ) foi uma mistura poderosa. Ela estimulou esforços para o desenvolvimento de um teste eficiente, a despeito de todos os sérios obstáculos iniciais. A difusão deste teste permitiu, em contrapartida, modificações nas ciências biomédicas (o desenvolvimento da serologia), na "medicina de beira de leito" (modificações práticas no diagnóstico e terapia da sífilis, a redefinição do 'paciente sifilítico' como um 'indivíduo

15 O Wassermann reagins medido para este teste apareceu no sangue de pacientes sifilíticos, mas não era específico para antígenos treponemais.

16 Depois da segunda Guerra Mundial, a equação de Wassermann: indivíduo soro-positivo= pessoa infectada pelo treponema foi substituída pela noção de que pessoas que sofrem de doenças como lupus ou tuberculose são 'falso positivos biológicos' da reação Wassermann (More \& Mohr, 1952).

17 Nos anos de 20 e 30, o teste Wassermann era considerado confiável apenas se realizável por peritos. A divulgação deste teste foi, portanto, vinculada à extensão de redes de especialistas capazes de conduzir este teste. Fleck nota que no dia-a-dia da medicina popular de seu tempo, "a reação Wassermann é frequientemente referida como sendo simplesmente um 'teste sorológico'” (Fleck, 1979: 14). 
Wassermann positivo'), na sociedade (o fim da percepção da sífilis como um 'estigma hereditário' e sua substituição pela visão da sífilis como uma doença infecciosa), e finalmente os usos, as implicações e a compreensão do próprio teste Wassermann (Löwy, 1993a). Quando um fato científico produzido por um grupo de pensadores é adotado por outro grupo, explica Fleck, é traduzido para o estilo de pensamento deste último. Esta 'tradução' é, contudo, fadada a ser imperfeita porque o estilo de pensamento de um novo grupo de pensadores é, pelo menos em parte, incomensurável com relação ao estilo do grupo que produziu o 'fato'. Isto não é necessariamente uma desvantagem: o novo 'fato' modifica e enriquece o estilo de pensamento pelo qual ele é assimilado, e é, em troca, modificado pelo novo estilo: "um conjunto de descobertas espraiando-se por toda a comunidade, sendo aperfeiçoado, transformado, reforçado ou atenuado, e, por sua vez, influenciando outras descobertas e a formação de conceitos, opiniōes e hábitos de pensamento" (Fleck, 1979:42). Algumas coisas podem se perder, mas outras podem ser descobertas na(s) tradução(es): a circulação de fatos científicos entre os grupos de pensadores distintos e incomensuráveis é uma importante fonte de inovação na ciência e na sociedade (Fleck, 1986:103) ${ }^{18}$.

\section{HISTORIOGRAFIA DO LABORATÓRIO BIOMÉDICO HOJE: GÊNESE, ESTABILIZAÇÃO E DIFUSÃO DO SABER BIOMÉDICO}

Estudos recentes sobre laboratórios biomédicos concentraram-se na 'gênese de fatos científicos' em um único laboratório. Investigaram-se o planejamento e a execução de experimentos, a divisão do trabalho no laboratório, a replicação, o papel das habilidades e instrumentos, das inscrições e das representações $^{19}$. Por outro lado, estes estudos negligenciaram, com freqüência, as interações dos 'fatos científicos', desenvolvidos por um estilo de pensamento dado, com estilos de pensamento diferentes (e incomensuráveis). Ultimamente, entretanto, estudiosos dos laboratórios biomédicos desenvolveram um interesse pelas interaçōes do mundo do laboratório com outros mundos sociais, e pelas

18 A 'natureza' e a 'cultura', explicou Fleck, estão interrelacionadas. Graças à teoria dos estilos de pensamento, "a lacuna entre a 'natureza' e a 'cultura' desaparece gradualmente porque a atividade cognitiva não é uma ação unilateral (...) mas consiste numa interação bilateral. $O$ estilo de pensamento cria realidade, do mesmo modo que os outros produtos da cultura e, ao mesmo tempo, ele mesmo sofre certas mudanças harmoniosas" (Fleck, 1986d; 112)

19 Ver as etnografias de laboratório como: Latour \& Woolgar 1979; Knorr-Cetina, 1981, e estudos históricos dos laboratórios biomédicos, por exemplo: Lenoir, 1986; Holmes, 1989. Estes estudos podem ser comparados aos estudos etnográficos e históricos de física, por exemplo: Pickering, 1984; Galison, 1987; Gooding, 1990. 
aproximações (como negociação, alinhamento, articulação, triangulação, simplificação) que contribuem para a construção coletiva do conhecimento por membros de mundos sociais diferentes (ou coletividades de pensamento ${ }^{20}$. Estes estudos mostraram a importância dos reagentes padronizados, dos instrumentos e dos organismos para tornar o conhecimento e as práticas de laboratório estáveis, assim como para sua difusão fora do laboratório. Eles também investigaram as articulações entre o laboratório biomédico e as clínicas, a indústria e as forças armadas. Por fim, seguiram as 'traduções' dos problemas médicos para o estilo de pensamento do laboratório (ou indústria) e seu corolário, a 'naturalização' do conhecimento e dos 'fatos' produzidos no laboratório pelas clínicas ou pela indústria. A segunda parte deste trabalho pesquisa alguns destes assuntos.

\subsection{Instrumentos, Reagentes e Padronização: do conhecimento local aos 'fatos científicos'}

Estudos recentes dos laboratórios biomédicos afirmam que os instrumentos, os reagentes e os métodos utilizados no ofício do conhecimento científico não apenas moldam e tornam este conhecimento estável, como também facilitam sua difusão. O sucesso da bacteriologia, no final do século XIX esteve estreitamente relacionado com a difusão das técnicas e ferramentas bacteriológicas. Os estudantes do curso de microbiologia do Instituto de Higiene da Universidade de Berlim adquiriram as habilidades rotineiras desenvolvidas no laboratório de Koch, enquanto na França as técnicas bacteriológicas padrão eram difundidas pelo Cours de Microbie Technique do Instituto Pasteur. Os preparos comerciais de cultura média, vidraria de laboratório e aparato bacteriológico contribuíram para a uniformização das práticas laboratoriais, ao mesmo tempo que as conferências dedicadas à padronização de testes bacteriológicos e serológicos permitiam o consenso posterior sobre as normas e os métodos (Cossel, 1992; Löwy, 1992). Mais tarde, o repertório dos métodos e ferramentas bacteriológicos estáveis mantiveram a continuidade das tradições experimentais neste domínio, e influenciaram o modo pelo qual as asserções (incluindo as asserções heterodoxas) poderiam ser formuladas e testadas (Amsterdamska, 1991).

Os instrumentos científicos contribuíram para a padronização, a estabilização e a difusão do conhecimento biomédico. Por exemplo, o aparelho Tiselius, para separação e estudo das proteínas, desenhado e desenvolvido no período de 1930-1940, só era encontrado, na década de 30, em instituições de pesquisa selecionadas. De modo contrastante, nos anos 50, havia, pelo menos, quatro mo-

20 Por exemplo: Law, 1966, Fujimura, 1987; Star, 1989. 
delos comerciais deste aparelho no mercado, tendo-se tornado parte do aparato de pesquisa semipadronizada em pesquisa biomédica. $O$ desenvolvimento do aparelho Tiselius refletiu a convicção dos seus criadores de que o estudo das propriedades físico-químicas das proteínas possuía a chave de importantes fenômenos biológicos, ao mesmo tempo em que a sua difusão fixava e propagava tal conviç̧ão. Além do mais, o interesse pelas propriedades das proteínas atravessou as linhas disciplinares. $O$ aparelho Tiselius facilitou a colaboração entre membros de diferentes grupos de pensadores (físicos, químicos, biólogos, médicos clínicos), através da mediação de uma técnica compartilhada. A introdução deste aparelho - então complexo e caro - nos laboratórios biomédicos também foi um passo importante para a transformação da biologia em 'ciência dura' após a Segunda Guerra Mundial (Kay, 1988).

Os anticorpos monoclonais (anticorpos monoespecíficos secretados pelas células 'hybridoma' geradas pela fusão de uma célula produtora de anticorpo com a célula do câncer) são um exemplo de reagentes produzidos em laboratório que moldaram a prática de um campo científico dado e levaram ao desenvolvimento de novos 'fatos científicos'. Uma série de seminários internacionais regulou e padronizou anticorpos monoclonais que foram utilizados para definir uma subpopulação específica de linfócitos. O estabelecimento de identidades entre os reagentes produzidos em diferentes locais, a padronização dos soros e a calibração dos instrumentos foi uma condição prévia para o desenvolvimento de uma rede de colaboração internacional entre os laboratórios imunológicos que estudavam os linfócitos. Os seminários internacionais estabeleceram, ainda, a classificação dos leucócitos, a assim chamada nomenclatura CD (Classe de Diferenciação). A difusão dos soros 'anti CD' padronizados, em contrapartida, levou à padronização dos laboratórios que os empregavam na elaboração de conceitos, reagentes, métodos e protocolos comuns. Tal difusão foi responsável, também, pela redefinição do campo de estudo dos leucócitos. Primeiramente, os anti-soros monoclonais eram desenvolvidos contra as populações de células definidas através das propriedades funcionais. Mais tarde, todavia, a definição de um novo antígeno CD transformouse no ponto de partida para a definição de sua função. Os soros anti CD descreviam (e mediam) populações de leucócitos e definiam o modo pelo qual tais populações deveriam ser estudadas. $O$ processo de consolidação e uniformização dos métodos de testar, portanto, estabilizou, concomitantemente, os fenômenos testados por estes métodos (Cambrosio \& Keating, 1992).

Os organismos vivos também podem ser padronizados e utilizados como instrumentos. Milho, moscas das frutas, camundongos e cobaias foram fundamentais para o desenvolvimento de programas de pesquisa específicos. Em inúmeros casos, tais organismos foram preparados e adaptados às necessidades específicas de uma dada pesquisa. Ao mesmo tempo, suas formas e sua 
uniformização moldavam os programas de pesquisa e as práticas de laboratório, facilitando, então, sua difusão. Assim, o laboratório de Morgan e seu programa de pesquisa em genética foram desenvolvidos graças a - e juntamente com - um único organismo: a drosófila. O compromisso com este sistema experimental foi muito mais do que o compromisso com um conjunto específico de problemas teóricos; foi o que assegurou a continuidade da escola de genética de Morgan (Kohler, 1991) 21 . Um outro organismo, o fungo Neurospora (ou melhor, 'Neurospora', um instrumento construído no laboratório), também foi inicialmente preparado para as investigações genéticas desenvolvidas no laboratório de Beadle, em Caltech, na década de 40. O 'Neurospora' foi considerado mais produtivo (tanto no sentido literal como no metafórico) para os estudos dos métodos bioquímicos. O sistema experimental deste organismo, baseado na necessidade de selecionar dezenas de milhares de mutantes, orientou a organização do trabalho neste laboratório. A organização semi-industrial da pesquisa levou ao desenvolvimento de biotestes para diversas substâncias biológicas, a novas idéias sobre relações entre genes e hormônios e à ligação dos interesses bioquímicos e genéticos (Kohler, 1991a). Levou, ainda, à associação com as forças armadas e à colaboração com a indústria química ${ }^{22}$.

\subsection{Laboratórios Biomédicos, Clínicas e Indústria:}

formação mútua de métodos e 'fatos'

A pesquisa biomédica precisa responder a demandas médicas e, freqüentemente, industriais. Pesquisas recentes sobre os laboratórios biomédicos investigaram os mecanismos de adaptação mútua entre 'fatos' biomédicos e clínicos. Eles assinalaram a importância da 'tradução' de questões médicas para questões biológicas, ou seja, para problemas que podem ser pesquisados no laboratório e naturalizados no 'estilo de pensamento' do laboratório (Amsterdamska, 1993:274). Tal 'tradução' está de acordo com a ideologia da medicina científica, que considera as ciências básicas como a principal fonte de inovação em medicina, e reflete a estratégia adotada no século XX para resolver problemas médicos. Estudos históricos recentes indicaram que tais 'traduções' de problemas médicos para biológicos podem mudar a direção de uma dada investigação. A pesquisa que co-

21 Alguns organismos concorrentes foram tão bem sucedidos, e não se transformaram em instrumentos padrão da investigação genética. Ver, por exemplo: Mitman \& Fausto Sterling, 1992.

22 Os estudos sobre o neurospora foram consolidados durante a Segunda Guerra Mundial pelo U.S. Office of Scientific Research and Development (OSRD), e foram mantidos, ao mesmo tempo, pela Merck Company, e mais tarde, pela Sharp and Dohm Company (Kay, 1989). 
meçava colocando questões sobre os estados patológicos poderia terminar questionando (e muitas vezes respondendo) sobre a fisiologia, a bioquímica e a genética dos organismos normais. As 'questôes médicas' podem levar a 'respostas biológicas' e os 'fatos médicos' podem ser traduzidos em 'fatos biológicos'. Por exemplo, os estudos (feitos por Albert Claude no laboratório do câncer do Instituto Rockfeller) sobre o 'agente do tumor' levaram à descoberta de partículas subcelulares (Löwy, 1990a:99-109; Rheinberger, 1993); as investigações (feitas por Paul Zamecnik na Escola Médica de Harvard) sobre as células cancerígenas conduziram a pesquisas sobre os mecanismos de síntese das proteínas (Rheinberger, 1993a); e o estudo sobre o 'agente transformador' dos pneumococci, conduzido por Oswald Avery e seus colaboradores no Hospital do Instituto Rockfeller, nas décadas de 30 e 40, foi, inicialmente, dirigido para o desenvolvimento do diagnóstico e para a cura da pneumonia, mas levou à afirmação de que o DNA contém informação genética (Amsterdamska, 1993). Em todos estes casos, a mudança para a investigação das questões biológicas orientou-se pelas práticas de laboratório. A orientação abrangente dos programas de pesquisa de cientistas como Avery, Claude e Zamecnik foi, em princípio (e para Avery permanentemente) moldada por questões médicas. Entretanto, suas estratégias foram construídas pelo raciocínio químico ou biológico e as suas práticas experimentais do dia-a-dia e seus interesses formaram-se pelas considerações técnicas e pelos materiais e métodos disponíveis.

A 'tradução' da medicina para a pesquisa biomédica nem sempre é unidirecional. A "biologia dura" atual depende das articulações bem-sucedidas com as demandas médicas, com os interesses criadores dos políticos e dos capitalistas especuladores. As demandas da área médica e da indústria muitas vezes interagem com a pesquisa biomédica, e as 'traduções' multidirecionais podem moldar tanto a pesquisa biomédica quanto as práticas médicas e industriais. $O$ estudo dos oncogenes pode exemplificar tais interações. Os oncogenes (genes celulares considerados implicados na transformação maligna da célula) foram descritos, em primeiro lugar, pelos virologistas e foram vinculados à transformação das células pelos vírus oncogênicos. Os estudos do oncogene (como os estudos do grupo de Scolnick no Instituto Nacional do Câncer (EUA)) mudaram, todavia, no final dos anos 70 e início dos anos 80 , de estudos dos vírus do câncer para estudo dos 'oncogenes celulares'. Esta transição foi moldada não só por circunstâncias materiais, como a difusão das técnicas da engenharia genética, mas também por outros acontecimentos: o fracasso do Programa Vírus-Câncer do Instituto Nacional do Câncer (EUA) e a crescente importância das conexões entre os laborató- 
rios biomédicos e empresas de biotecnologia (Gaudillière, 1992 e 1993) ${ }^{23}$. A estabilização dos oncogenes como fenômenos biológicos, e sua difusão nos diversos 'mundos sociais' (biólogos moleculares, biólogos celulares, pesquisadores do câncer, oncologistas clínicos), estava vinculada à generalizaço de métodos padronizados de pesquisa em biologia molecular, e de reagentes padronizados (investigações sobre o DNA, anticorpos monoclonais). A colaboração com os industriais influenciou não só o amplo direcionamento dos estudos do oncogene mas também a rotina de trabalho no laboratório. Os industriais que financiaram a pesquisa sobre reagentes usados em estudos utilizando oncogene esperavam obter produtos comercializáveis. Por outro lado, o trabalho dos cientistas era determinado pelas suas próprias agendas e pelas contingências do trabalho de laboratório. A definição de um 'produto confiável' foi estabelecida através de complexas negociações entre cientistas e industriais. Estas negociações afetaram o conteúdo dos estudos conduzidos no laboratório, mas também redefiniram as demandas dos industriais (Fujimura, 1987 e 1992).

As relações triangulares entre laboratórios biomédicos/clínica/indústria (tendo, na retaguarda, órgãos governamentais e políticos) não são novas. Os laboratórios biomédicos têm uma longa tradição de relações estreitas com as indústrias farmacêutica e química. Os estudos de Paul Ehrlich sobre a imunidade e a quimioterapia das doenças infecciosas, desde o início, estavam associados às demandas da indústria (e com fundos provenientes da indústria). Seu laboratório em Steglitz, subúrbio de Berlim - o Institute for Serum Research and Serum Testing (fundado em 1896) - e, posteriormente, outros laboratórios que ele dirigiu o Royal Institute for Experimental Therapy e o Georg Speyer Haus (ambos em Frankfurt) - vincularam o estudo dos problemas médicos fundamentais à solução de problemas práticos que interessavam à indústria química. $A$ associação de Ehrlich com a indústria não era um meio para atingir um fim (isto é, uma maneira de obter verba para a pesquisa básica) mas era fundamental para a sua perspectiva científica. Um dos feitos científicos mais importantes de Ehrlich - o desenvolvimento dos métodos de quantificação de anticorpos específicos no soro — desenvolveu-se de acordo com a estrutura dos acordos de colaboração com as companhias químicas (Hoechst, Merck e Schering), interessadas na comercialização dos soros antidiftérico e antitetânico. O desenvolvimento de um método seguro para testar a potência dos anti-soros e desenvolver os controles de qualidade foi uma condição prévia para transformar os anti-soros em drogas comer-

23 Os vínculos entre oncogenes celulares e a indústria foram exemplificados pela trajetória de Scolnick, que deixou o Instituto Nacional do Câncer em 1982 para chefiar a Unidade de Oncogene no centro de pesquisa de uma importante companhia farmacêutica, a Merck Laboratories. 
cializáveis. O sucesso de Ehrlich no desenvolvimento deste método levou ao estabelecimento de um novo campo de investigação científica básica: o estudo de anticorpos humorais (Baümler, 1984; Liebenau, 1990) ${ }^{24}$.

Os estudos dos hormônios sexuais humanos são um outro exemplo do papel do estabelecimento dos sistemas padronizados, para testar e avaliar os produtos, nas interações dos laboratórios biomédicos, com a indústria e com a clínica. De 1920 a 1930, o desenvolvimento de testes que identificavam e mediam os hormônios, e sua conseqüente padronização e aferição a partir das conferências internacionais, transformou o estudo dos hormônios sexuais em respeitável campo da investigação científica. A existência de métodos que permitiam que se testassem a pureza e a atividade dos produtos também abriu caminho para a produção comercial dos hormônios sexuais humanos. Os estudos do isolamento e da caracterização dos hormônios sexuais foram mantidos pelas companhias farmacêuticas (Parke \& Davis, Schering Kalhbaum, Organon). Estas companhias não apenas forneciam fundos para pesquisa, mas organizavam redes para coletar as matérias-primas (como a urina de mulheres grávidas), necessárias para o isolamento e a purificação dos hormônios sexuais. Isto, em contrapartida, associava companhias a redes de ginecologistas que forneciam tais matérias-primas. Os ginecologistas eram, também, os primeiros clientes dos hormônios em forma de droga. Suas ligações com a indústria facilitaram a formação e a comercialização dos hormônios como terapia para uma ampla faixa de 'queixas femininas'. Nos anos 20 e 30, a existência de densas redes de colaboração entre cientistas de laboratório, industriais e clínicos permitiu a 'tradução' do conceito teórico de 'hormônios sexuais' para drogas especializadas. O jogo de interesses mútuo de cientistas, industriais e médicos, por sua vez, levou à transformação dos hormônios sexuais femininos em 'ciência dura' e 'alto negócio' (Oudshoorn, 1991).

\section{4. 'OBJETOS FRONTEIRIÇOS', 'CONOTAÇÃO', 'TRADUÇÕES' E 'ZONAS DE NEGOCIAÇÃO': INSTRUMENTOS DE AFERIÇÃO PARA A HISTORIOGRAFIA DA PESQUISA BIOMÉDICA}

A comunidade de cientistas biomédicos é, por definição, intimamente ligada a outros 'mundos sociais'. Os pesquisadores biomédicos trabalham na interseção do 'bio' mundo das ciências fundamentais com o mundo 'médico' composto por médicos, industriais, administradores da saúde e pacientes ${ }^{25}$. Por mui-

24 A biografia de Baümler por Ehrlich foi patrocinada pela companhia Hoechst AG e enfatizou o papel de Ehrlich como cientista da companhia Hoechst.

25 Para discussão sobre comunidades científicas 'abertas' e 'fechadas' ver: Porter, 1991. 
to tempo, esta posição particular dos pesquisadores biomédicos não era percebida como problemática porque a ideologia de 'medicina científica' afirmava um progresso linear, desde a descoberta de fatos novos sobre as doenças humanas no laboratório até a sua aplicação na clínica (Medawar, 1977; Thomas, 1988). Estudos históricos recentes mostraram, contudo, interações mais complexas entre comunidades heterogêneas de cientistas e médicos clínicos; mostraram, ainda, os múltiplos usos da ciência na medicina e da medicina na ciência ${ }^{26}$. Novos estudos voltaram-se para a questão da estabilização e da difusão do conhecimento e dos 'fatos' produzidos no laboratório. Tais estudos enfocaram a padronização e a estabilização dos instrumentos e dos reagentes, assim como sua assimilação pelos diferentes grupos de pensadores.

Os novos interesses dos historiadores da pesquisa biomédica não devem ser, contudo, erroneamente interpretados como uma tentativa de substituir uma história simplificada - a transferência linear das descobertas das ciências biomédicas para a clínica - por uma outra história simplificada - o 'endurecimento' progressivo e a estabilização de fatos cientíicos, graças a uma melhor aferição e padronização de métodos e instrumentos. A padronização e a fixação do conhecimento e das práticas estão longe de ser processos simples, unidirecionais. Os grupos profissionais, que se esforçam para manter sua autonomia e seu prestígio, precisam ter o controle do acesso ao conhecimento padronizado e transmissível que thes permite competir com a incerteza; mas, ao mesmo tempo, precisam assegurar-se de que seus métodos e habilidades não sejam reduzidos a rotinas das quais qualquer pessoa pode se apoderar. Eles tentam encontrar um ponto intermediário que lhes permita codificar os padróes de comportamento profissional, deixando-lhes, porém, espaço suficiente para o conhecimento (individualizado) especializado (Whitley, 1984). Além do mais, pode existir uma contradição entre um 'estilo de pensamento' rígido e uma inovação (Fleck, 1979:93). Tal contradição pode tornar-se um fator restritivo na transferência de uma técnica desenvolvida em laboratório para um local industrial ou semi-industrial. A novidade é um componente importante para a possibilidade de negociação de um produto derivado da ciência. A codificação rígida de um produto pode elevar a possibilidade imediata de sua comercialização, mas atrapalhar seu destino no mercado (Fujimura, 1987:282). A rigidez pode atrapalhar, ainda, a colaboração que ultrapassa as fronteiras profissionais (como aquelas existentes entre médicos e cientistas biomédicos), pois o sucesso de tal colaboração pode depender da evolução de uma demanda negociada localmente.

Se o excesso de estabilização dos fatos científicos - e dos conceitos científicos - pode ser contraproducente, uma certa dose de estabilização de métodos e 'fatos' é necessária para assegurar sua circulação entre grupos de pensadores. No entanto, os estudiosos do laboratório notaram que os objetos (reagentes, instrumentos, métodos) que circulam entre os diferentes grupos de pensadores das ciências biomédicas freqüen-

26 Ver: Rozenkratz, 1974; Geison, 1979; Maulitz, 1979; Warner, 198 ; Kohler, 1982; Löwy, 1989; Sturdy, 1992. 
temente não são objetos rígidos, 'caixas pretas' permanentemente lacradas (Latour, 1987:2), mas são 'caixas cinzentas' (Fujimura, 1987) ou 'caixas translúcidas' (Jordan \& Lynch, 1992), ou seja, entidades que podem ser percebidas como rígidas pelos atores mas que têm, efetivamente, diferentes graus de flexibilidade nos diferentes locais. As ditas caixas 'cinzentas' ou 'translúcidas' podem ser retratadas como 'objetos fronteiriços'. O termo 'objetos fronteiriços ${ }^{27}$ foi usado pelos sociólogos da ciência para descrever entidades que apresentam estruturas frágeis no uso comum, e são fortemente estruturadas no uso local individual (Star \& Griesemer, 1988). Estes 'objetos fronteiriços' facilitam interações heterogêneas entre 'mundos sociais' distintos. Um objeto fronteiriço pode ser construído a partir de um 'núcleo rígido' - zona de acordo entre os grupos profissionais que interagem - e a partir de uma 'periferia difusa', indistinta, que é diferente para cada grupo. Por exemplo, a entidade Streptococcus haemolyticus, discutida por Fleck (1986b), pode ser descrita como um 'objeto fronteiriço', composto pelo núcleo rígido de características, que definem o $S$. haemolyticus para os bacteriologistas com orientação bioquímica e os epidemiologistas com orientação médica, assim como pela 'periferia difusa - os critérios (variáveis) para a inclusão de casos fronteiriços na entidade $S$. haemolyticus. Do mesmo modo, pode-se afirmar que o 'plasmid prep' (um instrumento de rotina no trabalho do biólogo molecular) é um 'objeto fronteiriço' composto pela definição, geralmente aceita desta entidade e pela 'periferia difusa', que inclui variaçóes locais induzidas em culturas de diferentes laboratórios (Jordan \& Lynch, 1992) ${ }^{28}$.

Talvez os 'objetos fronteiriços' não sejam as únicas entidades capazes de circular entre os 'grupos de pensadores' . O próprio estilo de pensamento (ou melhor, alguns de seus componentes) também o é. Pode-se afirmar, por exemplo, que grupos de pensadores (como imunologistas, biólogos celulares, médicos clínicos, cientistas industriais), que utilizam 'pacotes' de métodos, reagentes e instrumentos provenientes da biologia molecular ( $\mathrm{Fu}$ jimura, 1992), não somente aplicam um conjunto específico de técnicas como também adotam - e adaptam - elementos do estilo de pensamento dos biólogos moleculares. Uma tal 'conotação' ${ }^{29}$, isto é, a transposição e assimilação de elementos de um estilo de pensamento diferente (geralmente mais prestigiado) por um grupo de pensadores diverso, pode acar-

27 O termo 'objetos fronteiriços' foi usado pelos lingüistas para exprimir a indeterminabilidade da linguagem natural.

28 O preparado plasmídeo, que Jordan e Lynch afirmam, percebido pelos biólogos moleculares como uma entidade fixa e não problemática, pode talvez ser olhado como 'objetos fronteiriços' (ou metáforas) subdeterminados. (Gaudillière, 1993)

29 Em semiologia, um termo conotativo aparece quando o signo de um sistema inicia a expressão simples, ou o significante de um segundo sistema, por exemplo quando o estilo de uma frase transmite uma mensagem separada. A conotação é uma forma de retórica (Barthes, 1964:163-168). 
retar benefícios concretos para o grupo que assimila estes elementos de estilo ${ }^{30}$. Por exemplo, a adoção de um estilo de pensamento 'científico' pelos médicos elevou sua posição econômica e seu estatuto social, fortaleceu a posição das especialidades médicas, intensificou o papel dos médicos no controle das populações e modificou as relações médico-paciente ${ }^{31}$. Também facilitou a colaboração entre médicos clínicos e cientistas. Os 'objetos fronteiriços' e as 'conotações' podem ser tomados como artifícios que possibilitam o desenvolvimento de 'zonas de interesse' ou 'zonas francas', ou seja, zonas de interação entre mundos sociais heterogêneos. Tais zonas permitem a coordenação local das atividades dos membros de grupos de pensadores (ou de culturas profissionais) distintos, que continuam fiéis aos seus diferentes estilos de pensamento (Löwy, 1992a:374-375).

Os historiadores dos laboratórios biomédicos estudam os atores e as práticas, não as 'descobertas' ou o 'progresso da ciência'. O quadro gerado por estas abordagens pode parecer um tanto confuso. A pesquisa biomédica é definida como um campo complicado que tem fronteiras contingentes e negociáveis. Esta área é dividida em jurisdições moduláveis que estão (provisoriamente) estabilizadas pela fidelidade a um estilo de pensamento específico, e que interagem com outras jurisdições por uma circulação multidirecional de 'objetos fronteiriços' semi-estabilizados. A nova imagem da pesquisa biomédica é provavelmente menos tranqüilizadora do que a visão tradicional dos laboratórios como templos da ciência, nos quais observadores objetivos e intercambiáveis desvelam os fatos ocultos da natureza, aplicando-os, então, na deteç̧ão e cura da doença humana. Ela pode, contudo, ser mais adaptada para explicitar as frustrações e os estímulos desta atividade humana multifacetada chamada 'pesquisa biomédica'.

30 Os historiadores apontaram o papel 'estilístico' das abordagens, tais como 'precisão' e 'quantificação' na formação da prática científica e as relações sociais dos cientistas. Ver por exemplo: Daston (no prelo); Porter, 1992

31 Por exemplo: Maulitz, 1979; Warner, 1986; Oudshoorn, 1991; Sturdy, 1992. 


\section{BIBLIOGRAFIA GERAL}

\section{Capítulo 1}

CANGUILHEM, G. (1955), La Formation du Concept de Réflexe au XVIIème et XVIIIème Siècle. Paris: P.U.F. (1966), Le Normal et le Pathologique, Paris: P.U.F. . (1967), La Théorie Cellulaire, In: CANGUILHEM, G. La Connaissance de la Vie. Paris: Vrin, $2^{\mathrm{a}}$ ed., p. 79. P.U.F. (1971), De la Science et de la Contre-Science, In: Hommage à Jean Hyppolite. Paris: (1977), Idéologie et Racionalité dans L'Histoire des Sciences de la Vie. Paris: Vrin. . Vie, In: Encyclopaedie Universali, s/d, 766b-c.

FOUCAULT, M. (1963), La Naissance de la Clinique. Paris: P.U.F.

NIETZSCHE, F. (1955), Le Gai Savoir. Paris: Gallimard.

PIAGET, J. (1967), Epistémologie de la Biologie, In: Logique et Connaissance Scientifique, Paris: Gallimard.

\section{Capítulo 2}

BENTHAM, Geremy. (1977), Le Panoptique. Paris: Éditions Pierre Belfond.

DREYFUS, H. \& RABINOW, P. (1983), Michel Foucault. Beyond Structuralism and Hermeneutics. Chicago: The University of Chicago Press.

ERIBON, D.(1990), Michel Foucault 1926-1984. Rio de Janeiro:Companhia das Letras.

FOUCAULT, Michel (1966), Les Mots et les Choses: une Archéologie des Sciences Humaines. Paris: Gallimard. . (1969), L'Archéologie du Savoir. Paris: Gallimard. (1972), Histoire de la Folie à l'âge Classique. Paris: Gallimard, $2^{\mathbf{a}}$ ed. (1975), Surveiller et Punir: Naissance de la Prison. Paris: Gallimard. (1977a), História da Sexualidade I - A Vontade de Saber. Rio de Janeiro:Graal. (1977b), O Nascimento da Clínica. Rio de Janeiro:Forense Universitária. (1979), A Verdade e as Formas Jurídicas. Cadernos da PUC-RJ, Rio de Janeiro:D.I.E., $1^{\text {a }}$ Conferência. (1982), Microfisica do Poder. Rio de Janeiro: Graal. (1983), Structuralism and post-structuralism. Telos, vol 16, $\mathrm{n}^{\circ}$ 55, Spring, pp.192-211. (1984), História da Sexualidade II.O Uso dos Prazeres. Rio de Janeiro: Graal. (1989), Isto Não é um Cachimbo. Rio de Janeiro: Paz e Terra.

KEENAN, Tom. (org.)(1988), The Final Foucault. Cambridge: Mass., Mit Press. 
MACHADO, R. (1981), Ciência e Saber: a Trajetória Arqueológica de Michel Foucault. Rio de Janeiro: Graal. . (1990), Deleuze e Foucault, In: Deleuze e a Filosofia. Rio de Janeiro: Graal.

\section{Capítulo 3}

EINSTEIN, A. \& INFELD, L. (1966), The Evolution of Physics. Nova York: Simon and Schuster.

KUHN, T. (1957), The Copernicon Revolution. Harvard University Press. . (1970), The Structure of Scientific Revolutions, In: Foundations of the Unity of Science .vol.II. Chicago: The University of Chicago Press. . (1976a), Logic of Discovery or Psycology of Research?, In: LAKATOS, I. \& MUS-

GRAVE, A. (orgs.), Criticism and the Growth of Knowledge. Cambridge University Press. (1976b), Reflections on My Critics, In: LAKATOS, I. \& MUSGRAVE, A. (orgs.),

Criticism and the Growth of Knowledge. Cambridge University Press. . (1977a), Second Thoughts on Paradigms, In: SUPPE, F. (org.), The Structure of

Scientific Theories. University of Illinois Press.

(1977b), The Essential Tension. Chicago: The University of Chicago Press. . (1980), Los Paradigmas Científicos, In: BARNES, B. et al., Estudios sobre Sociología de la Ciencia. Madrid: Alienza Editorial.

LAKATOS, I. (1976), Falsification and the Methodology of Scientific Research Programs, In: LAKATOS, I. \& MUSGRAVE, A. (orgs.), Criticism and the Growth of Knowledge. Cambridge University Press. \& MUSGRAVE, A. (orgs.) (1976), Criticism and the Growth of Knowledge. Cambridge University Press.

MASTERMAN, M.(1976), The Nature of a Paradigma , In: LAKATOS, I. \& MUSGRAVE, A. (orgs.), Criticism and the Growth of Knowledge. Cambridge University Press. MORICK, H. (org.) (1980), Challenges to Empiricism. Londres: Methuen. POPPER, K. (1968). The Logic of Scientific Discovery. Londres: Hutchinson. (1986) Objective Knowledge. An Evolutionary Approach. Oxford. . (1989). Conjectures and Refutations. Londres: Routledge and Kegan Paul, Clarendon Press.

RADNITZKY, G. (1979), Contemporary Philosophical Discussion as Debates between Early Wittgensteinians, Popper and Later Wittgensteinians. Manuscrito. Campinas, vol.II, $\mathrm{n}^{\circ} 2$. SCHEFFLER, T. (1967), Science and Subjectivity. Nova York: Bobs Merril Co.

SHAPERE, D. (1964), The Structure of Scientific Revolution. Philosophical Review, $\mathrm{n}^{\circ} 73$, pp. 376-385.

SUPPE, F. (org.) (1977), The Structure of Scientific Theories. University of Illinois Press. TOULMIN, S. (1972), Human Understanding. Oxford: Clarendon Press. 


\section{Capítulo 4}

FEYERABEND, P. (1977), Contra o método. Rio de Janeiro: Livraria Francisco Alves Editora. (tradução da edição de 1975). . (1978), Science in a Free Society. Londres: NLB. (1979), Consolando o Especialista, In: LAKATOS I. \& MUSGRAVE, A. (orgs.) A Crítica e o Desenvolvimento do Conhecimento. São Paulo: Editora Cultrix/Editora da Universidade de São Paulo. (1981), Philosophical Papers. volume 2. Londres: Cambridge University Press. (1987), Adiós a la Razón. Madrid: Tecnos. (1993a), Against Method. Londres, New York: Verso. (1993b), Contra o Método. Lisboa: Relógio d’Água. (tradução da edição inglesa revista de 1988).

HALL, R.J.(1979), Se Puede Utilizar la Historia de la Ciencia para Decidir entre Metodologías Rivales?, In: LAKATOS, I \& MUSGRAVE, A., (orgs.) A Crítica e o Desenvolvimento do Conhecimento. São Paulo: Editora Cultrix/Editora da Universidade de São Paulo. KANT, I.(1974), Crítica da Razão Pura. São Paulo: Abril Cultural, 1974, $1^{2}$ edição. KUHN, T.(1975), A Estrutura das Revoluçōes Científicas. São Paulo: Editora Perspectiva. . (1979), Reflexões sobre os Meus Críticos, In: LAKATOS, I. \& MUSGRAVE, A.(orgs.) A Crítica e o Desenvolvimento do Conhecimento. São Paulo: Editora Cultrix/Editora da Universidade de São Paulo.

. (1987), Notas sobre Lakatos, In: LAKATOS, I. Historia de las Ciencias y sus Reconstrucciones Racionales. Madrid: Tecnos.

LAKATOS, I. (1979), O Falseamento e a Metodologia dos Programas de Pesquisa, In: LAKATOS, I. \& MUSGRAVE, A. (orgs.) A Crítica e o Desenvolvimento do Conhecimento. São Paulo: Editora Cultrix/Editora da Universidade de São Paulo.

. (1987a), Historia de las Ciencias y sus Reconstrucciones Racionales. Madrid: Tecnos. . (1987b), Respuestas a las Críticas, In: LAKATOS,I., Historia de las Ciencias y sus Reconstrucciones Racionales. Madrid: Tecnos.

. \& MUSGRAVE, A. (orgs.) (1979), A Crítica e o Desenvolvimento do Conhecimento. São Paulo: Editora Cultrix/Editora da Universidade de São Paulo.

POPPER, K. (1975a), A Lógica da Pesquisa Científica. São Paulo: Editora Cultrix / Editora da Universidade de São Paulo.

. (1975b), Conhecimento Objetivo. Belo Horizonte: Editora Itatiaia /São Paulo: Editora da Universidade de São Paulo .

\section{Capítulo 5}

BOURDIEU, P. (1983), O Campo Científico, In:ORTIZ, Renato (org.), Pierre Bourdieu: Sociologia. São Paulo: Ática. . (1987a), Uma Interpretação da Teoria da Religio de Max Weber, In: MICELLI, Sérgio (org.) A Economia das Trocas Simbólicas. São Paulo: Perspectiva. 
(1987b), O Mercado de Bens Simbólicos, In:MiCELLI, Sérgio (org.), A Economia

das Trocas Simbólicas. São Paulo: Perspectiva.

. (1987c), Sistema de Ensino e Sistema de Pensamento, In: MICELLI, Sérgio (org.). A Economia das Trocas Simbólicas, São Paulo: Perspectiva.

et al. (1988), El Ofício del Sociólogo. Mexico, D.F., Siglo XXI, $11^{\mathrm{a}}$ edição.

. (1989), Introdução a uma Sociologia Reflexiva, In: BORDIEU, P., O Poder Simbóli-

co. Lisboa: Difel/Bertrand Brasil, pp.17-58.

.(1989a), Le Mort Saisit le Vif. As Relações entre a História Reificada e a História Incorporada, In: BOURDIEU, P. O Poder Simbólico. Lisboa: Difel/Bertrand Brasil.

RANNIGAN, Augustine. (1984). A Base Social das Descobertas Científicas. Rio de Janeiro:

Zahar Editores.

HEKMAN, Susan (1990). Hermenêutica e Sociologia do Conhecimento. Lisboa: Edições 70.

KNORR-CETINA, K. \& MULKAY, M. (1983). Science Observed. Perspectives on the Social Study. Londres: SAGE Publications.

MANNHEIM, Karl (1967),O Problema de uma Sociologia do Conhecimento, In: MERTON, R. et al. Sociologia do Conhecimento. Rio de Janeiro: Zahar Editores.

. (1974a), O Problema da Intelligentsia. Um Estudo sobre seu Papel no Passado e no

Presente, In: MANNHEIM, K., Sociologia da Cultura, São Paulo: Perspectiva/EDUSP. . (1974b), A Democratização da Cultura, In: MANNHEIM, K., Sociologia da Cultura,

São Paulo: Perspectiva, EDUSP.

. (1976). Ideologia e Utopia. Rio de Janeiro: Zahar Editores, $3^{\mathbf{a}}$ edição.

MERTON, Robert (1970). Karl Mannheim e a Sociologia do Conhecimento, In: MERTON,

R., Sociologia. Teoria e Estrutura. São Paulo: Mestre Jou.

MULKAY, M. (1979). Science and the Sociology of Knowledge. Londres: George Allen \& Unwin.

\section{Capítulo 6}

BARNES, Barry. (1982), T.S. Kuhn and Social Sience. Londres: Macmillan Press.

BERLIN, Isaiah. (1959), The Hedgehog and the Fox. New York: Mentor Books.

BLOOR, David. (1976), Knowledge and Social Imagery. Londres: Routledge.

BOTTOMORE, T. \& NISBET, R. (orgs.) (1978), História da Análise Sociológica. Rio de Janeiro: Zahar, pp. 476-546.

BOURDIEU, Pierre. (1975), The Specificity of the Scientific Field and the Social Conditions of the Progress of Reason. Social Science Information, 14, n 6, pp. 304-317.

CARVALHO, Maria Alice Rezende de. (1991), Doutos e Loucos. Ensaio sobre a Identidade dos Intelectuais Contemporâneos. Presença. Cultura e Política. Rio de Janeiro: $\mathrm{n}^{\circ}$ 16, pp. $80-95$.

COLE, Jonathan \& ZCKERMAN, Harriet. (1985), The Emergence of a Scientific Especiality: the self-exemplifying case of the sociology of science, In: COSER, Lewis. (org.), The Idea of Social Structure. New York: Harcourt Brace Jovanovich, pp.139-174.

COOLLINS, H.Knowledge, Norms and Rules in the Sociology of Science. Social Studies of Science, London, vol. 12, n², pp. 299-306, may. 
COSER, Lewis. (1975), Merton's Uses of the European Sociological Tradition, In: COSER, Lewis. (ed.), The Idea of Social Structure. Papers in Honor of Robert K. Merton. New York: Harcourt Brace Jovanovich, pp. 85-101.

COSER, Rose L. (1975), The Complexity of Roles as a Seedbed of Individual Autonomy, In: COSER, Lewis. (ed.), The Idea of Social Structure. Papers in Honor of Robert K. Merton. New York: Harcourt Brace Jovanovich, pp. 237-264.

DAWE, Alan. (1980), Teorias da Ação Social, In: BOTTOMORE, T. \& NISBET, R. (orgs.) História da Análise Sociológica. Rio de Janeiro: Zahar, pp. 476-546.

GIERYN, Thomas. (1982), Relativist/Construtivist Programmes in the Sociology of Science: Redundance and Retreat. Social Studies of Science, London, vol.12, n², pp. 279-297, may. HOCHMAN, Gilberto. (1994), A Ciência entre a Comunidade e o Mercado. Leituras de Kuhn, Bourdieu, Knorr-Cetina e Latour in PORTOCARRERO, V.(org.). Filosofia, História e Sociologia das Ciências 1: abordagens contemporâneas. Rio de Janeiro: Editora Fiocruz.

KNORR-CETINA, Karin (1981). The Manufacture Knowledge. An Essay on the Construtivist and Contextual Nature of Science. Oxford: Pergamum Press.

- (1982a), Scientific Communities or Transepistemic Arenas of Research? a Critique of Quasi-economic Model of Science. Social Studies of Science, London, vol. 12, $\mathrm{n}^{\circ} 1, \mathrm{pp}$. 101-130, february.

(1982b), The Constructivist Programme in the Sociology of Science: Retreats or Advances? Social Studies of Science, London, vol. 12, $\mathrm{n}^{\circ} 2$, pp. 325-328, may.

\& MULKAY, M. (1983), Science Observed-perspectives on the Social Study of Science.

Beverlly Hills: Sage.

KUHN, Thomas. (1978), A Estrutura das Revoluções Científicas. São Paulo: Perspectiva. $2^{2}$ ed.

LATOUR, Bruno. (1983), Give Me a Laboratory and I Will raise the world, In: KNORR-CETINA, Karin \& MULKAY, Michael (eds). Science Observed - Perspectives on the Social Study of Science. Beverly Hills: Sage, pp. 141-170.

. (1987), Science in Action. Cambridge: Harvard University Press.

\& WOOLGAR, Steve. (1979), Laboratory Life.The Social Construction of Scientific

Facts. Beverlly Hills: Sage.

MANNHEIM, Karl. (1952), Essays on the Sociology of Knowledge. Oxford University Press. MERTON, Robert. (1970), Sociologia: Teoria e Estrutura. São Paulo: Mestre Jou.

(1973), The Sociology of Science.Chicago: University of Chicago Press.

(1975), Thematic Analysis in Science: Notes on Holton'Concept. Science, vol.188, 25

april, pp. 335-338.

(1977). The Sociology of Science: an episodic memoir, In: MERTON, R. \& GAS-

TON, J. (eds.), The Sociology of Science in Europe. Carbondalle III: Southern Illinois University Press, pp. 3-141.

MILES, Mary W. (1975), The Writtings of Robert K. Merton: a Bibliography, In:COSER, Lewis, (org.) The Idea of Social Structure. Papers in Honor of Robert K. Merton. New York: Harcourt Brace Jovanovich, pp. 497-522.

MILLS, Wright (1974), Conseqüências Metodológicas da Sociologia do Conhecimento, In: VELHO, Otavio et al., Sociologia do Conhecimento. Rio de Janeiro: Zahar, $2^{\mathrm{a}}$ ed. 
NISBET, Robert (1980), Conservantismo, In: BOTTOMORE, T. \& NISBET, R. (org.), História da Análise Sociológica. Rio de Janeiro: Zahar.

PALACIOS,Manuel.(1992), Ciência e Vida Pública. Presença. Cultura e Política, nº 17.

SOARES, Luis Eduardo.(1993), Os Dois Corpos do Presidente. Rio de Janeiro: ISER/Relume.

STORER, Norman. (1973), Introduction, In: MERTON, R. The Sociology of Science.

Chicago: The University of Chicago Press, pp.xi-xxxi.

WEBER, Max. (1974), Ensaios de Sociologia. Rio de Janeiro: Zahar.

\section{Capítulo 7}

BARNES, B. (1982), T.S. Kuhn and Social Science. Londres: The Macmillan Press.

BLOOR, D. (1976), Knowledge and Social Imagery. Londres: Routledge and Kegan Paul. . (1983), Wittgenstein. A Social Theory of Knowledge. Londres: The Macmillan Press. (1992), Ordinary Human Inference as Material for the Sociology of Knowledge.

Social Studies of Science, London, vol. 22, $\mathrm{n}^{\circ} 1$, fevereiro.

HARRÉ, Rom. (1981), Prefácio, In: The Manufacture of Knowledge. An Essay on the Constructivist and Contextual Nature of Science. Oxford: Pergamon Press.

KNORR-CETINA, Karin. (1981), The Manufacture of Knowledge. An Essay on the Constructivist and Contextual Nature of Science. Oxford: Pergamon Press.

KUHN, T. (1970), The Structure of Scientific Revolutions. Chicago: The University of Chicago Press.

LATOUR, B. (1987), Science in Action. How to Follow Scientists and Engineers through Society. Cambridge: Harvard University Press.

LANGLEY, P. et al. (1980), Rediscovering Chemistry with the Bacon System, In: MICHALSKI,R.S. et al. (eds.), Machine Learning: an artificial intelligence approach. Nova York: Springer-Verlag.

MICHALSKI, R. S. et al. (eds.) (1980), Machine Learning: An Artificial Intelligence Approach. Nova York: Springer-Verlag.

NOLA, Robert (1992), Ordinary Human Inference as Refutation of the Strong Programme, In: Social Studies of Science, Londres: vol. $22, \mathrm{n}^{\circ} 1$, fevereiro.

SIMON, Herbert. (1991), Comments on the Symposium on 'Computer Discovery and the Sociology of Scientific Knowledge'. Social Studies of Science, Londres: vol. 21, n 1, fevereiro.

SLEZAK, P. (1989), Computers, Contents and Causes: Replies to My Respondents. Social Studies of Science, Londres: vol. 19, $\mathrm{n}^{\circ} 4$.

WITTGENSTEIN, L. (1969), The Blue and Brown Books. Oxford: Blackwell, p.78

Capítulo 8

BARNES, B. (1982), T.S.Kuhn and Social Science. Nova York: Columbia University Press. BLOOR, D. (1976), Knowledge and Social Imagery. Londres: RKP.

BOURDIEU, P. (1975), The Specifity of the Scientific Field and Social Conditions of the Progress of Reason. Social Science Information, 14(6), 19-47. 
(1981),Men and Machines, In: KNORR-CETINA, K.\& CICOUREL, A. V. (eds.), Toward an Integration of Micro-and-Macro Sociologies. Boston: RKP.

(1983), O Campo Científico, In: ORTIZ, Renato (org.), Pierre Bourdieu. Sociologia.

São Paulo: Ática.

COLLINS, R.(1988), Theoretical Sociology. San Diego: Harcourt Brace Jovanovitch, Publishers.

GIERYN, T. F.(1982), Relativist/Constructivist Programmes in the Sociology of Science: redundance and retreat. Social Studies of Science, Londres, vol. 12, $\mathrm{n}^{\circ} 2$, pp. 279-297, maio.

KNORR-CETINA, K. (1981),The Micro-Sociological Challenge of Macro-Sociology : Towards a Reconstrution of Social Theory and Methodology, In: KNORR-CETINA, K. \& CICOUREL (ed.), Toward an Integration of Micro-and-Macro Sociologies. Boston: RKP, pp. 1-47. (1981a), The Manufacture Knowledge.An Essay on the Constructivist and Contextual Nature of Science. Oxford: Pergason Press.

(1982), Scientific Comunities or Transepistemic Arenas of Research ? A Critique of Quasi-Economic Model of Science. Social Studies of Science, Londres, vol. 12, $\mathrm{n}^{\circ} 1$, pp. 101-130, fevereiro. . (1983), The Etnographic Study of Scientific Work: Towards a Constructivist Interpretation of Science, In: KNORR-CETINA, K. \& MULKAY, M.(eds.) Science Observed. Perspective on the Social Study of Science. Beverly Hills: Sage.

. \& MULKAY, M. (eds.) (1983), Science Observed. Perspective on the Social Study of Science. Beverly Hills: Sage.

KUHN, T. S. (1962), The Structure of Scientific Revolutions. Chicago: University of Chicago Press.[Trad. brasileira: (1978), A Estrutura das Revoluções Científicas. São Paulo: Perspectiva, $2^{\underline{a}}$ ed.]

LATOUR, B. (1983), Give me the Laboratory and I will Raise the World, In: KNORR-CETINA, K. \& MULKAY, M.(eds.), Science Observed. Perspective on the Social Study of Science. Beverly Hills: Sage.

(1987), Science in Action. How to Follow Scientists and Engineers through Society.

Cambridge: Havard University Press.

\& WOOLGAR, S. (1979), Laboratory Life. The Social Construction of Scientific Facts.

Beverly Hills: Sage.

\& BOWKER, G. (1987), A Booming Short of Disciplines: (Social) Studies of Science in France. Social Studies of Science, Londres, vol. 17.

WOOLGAR, S. (1982), Laboratory Studies: a comment on state of art. Social Studies of Science, Londres, vol.12(4).

\section{Capítulo 9}

AMSTERDAMSKA, O. (1987), Medical and Biological Constraints: Early Research on Variation in Bacteriology. Social Studies of Science, Londres, 17(4), pp. 657-688. . (1991),Stabilizing Instability: the Controversy Cver Cyclogenic Theories of Bacterial Variation During the Intewar Period. Journal of the History of Biology, 24, pp. 191-222. 
(1993), Between Medicine and Science: the research career of Oswald T. Avery, In: LOWY, I.(ed.) Medicine and Change: innovation continuity and recurrence. Paris e Londres: John Libbey, pp. 253-283.

AUSTYN, J.M. (ed.) (1977), Beyond Tomorrow: trends and prospects in medical science. Nova York: Rochefeller University Press.

BACHELARD, G. (1987), Le Nouvel Esprit Scientifique, Paris: PUF. (1 a publicação 1934).

BARNES, B. \& EDGE, D. (1983), Science in Context: readings in the sociology of science. Cambridge: Mass., The MIT Press.

BARTHES, R. (1964), Le Dégré Zéro de la Literature. Paris: Gonthier.

BRANDT, A. (1991), Emerging Themes in the History of Medicine. Milbank Quaterly, 69, pp. 199-214.

BRANT, A. M. (1986), No Magic Bullet: a social history of venereal disease in the united states since 1880. Nova York e Oxford: Oxford University Press ( $2^{2}$ edição).

BAÜMLER, E. (1984), Paul Ehrlich: Scientist for Life. Nova York: Holmes Meyer.

CAMBROSIO, A. \& KEATING, P. (1992), A Matter of FACS: constituting novel entities in imunology. Medical Anthropology Quaterly, 6, pp. 362-384.

CATWRIGHT, N. (1983), How the Laws of Physics Lie. Oxford: Clarendon Press.

CLARKE, A.E. \& FUJIMURA, J.H. (1992), The Right Tools for the Job. Princeton: Princeton University Press.

COHEN, R.S. \& SCHNELLE, T. (eds.) (1986), Cognition and Fact: materials on Ludwik Fleck. Dordrecht: D. Reidel.

(1986a), Introduction. In: COHEN, R. S.\& SCHNELLE, T. (eds.), Cognition and Fact: materials on Ludwik Fleck. Dordrecht: D.Reidel, pp. IX-XXXIII.

FLECK, L. (1979), Genesis and Development of a Scientific Fact. Chicago: University of Chicago Press.

. (1986 a), Some Specific Features of the Medical Way of Thinking, In: COHEN, R.S. \& SCHNELLE,T.(eds), Cognition and Fact: materials on Ludwik Fleck. Dordrecht: D.Reidel, pp.39-46.( $1^{\text {a }}$ public. 1927).

(1986 b), On the Crisis of Reality, In: COHEN, R. S. e SCHNELLE, T. (eds.) Cognition and Fact: materials on Ludwik Fleck. Dordrecht: D.Reidel, pp. 47-56.(1 ${ }^{\text {a }}$ public. 1929). (1986 c), Scientific Observation and Perception in General, In: COHEN, R. S. e SCHNELLE, T. (eds) Cognition and Fact: materials on Ludwik Fleck. Dordrecht: D. Reidel, pp. 59-78.

(1986 d), The Problem of Epistemology, In: COHEN, R. S. e SCHNELLE, T. Cognition and Fact: Materials on Ludwik Fleck. Dordrecht: D. Reidel, pp.79-112.

FREUDENTHAL, G. \& LOWY, I. (1988), Ludwik Fleck's Roles in Society; a Case Study Using Joseph Ben David's Paradigm for a Sociology of Knowledge. Social Studies of Science, Londres, 18, pp .625-651.

FUJIMURA, J.H. (1987), Constructing Do-able Problems in Cancer Research: articulating alignement. Social Studies of Science, Londres, 17, pp. 257-293.

. (1988), The Molecular Biology Bandwagon in Cancer Research: articulating alignment. Social Problems, 35, pp. 261-283. 
(1992),Crafting Science: standardized packages, boundary objects and translations, In: PICKERING,A. (ed.), Science as Practice and Culture. Chicago e Londres: The University of Chicago Press, pp. 168-211.

GALISON, P. (1987), How Experiments End. Chicago: The University of Chicago Press. GAUDILLIRE, J.P. (1992), Building Laboratory Models for Cancer: Rodent viruses and transfection at the national cancer institute (U.S). Palestra proferida no workshop Experimental Systems in Biological and Medical Sciences. Lubeck: novembro, 19-21.

(1993),Oncogenes as Metaphors for Human Cancer: articulating laboratory practices and medical demands, In: LOWY, I. (ed.), Medicine and Change: innovation continuity and recurrence. Paris e Londres: John Libbey, pp. 284-319.

GEISON, G.L. (1979), Divided We Stand: Physiologists and Clinicians in the American Context, In: VOGEL, M.J \& ROSEMBERG, C.E. (orgs.) The Therapeutic Revolution: essays in the social history of american medicine. Filadélfia: University of Pennsylvania Press, pp. 67-90. GOODING, D. \& PINCH,T .J. e SCHEFFER, S. (eds.)(1989), The Uses of Experiment: studies in the natural sciences. Cambridge: Cambridge University Press.

(1990), Experiments and the Making of Meaning. Dordrecht: Kluwer.

GOSSEL, P.P. (1992), A Need for Standard Methods: the case of american bacteriology, In: CLARKE, A. E. \& FUJIMURA, J. H. The Right Tools for the Job. Princeton: Princeton University Press, pp.287-311.

HADLEY, P. (1927), Microbic Dissociation. Journal of Infections Diseases, 40, pp. 1-312. HACKING, I. (1983), Representing and Interwining. Cambridge: Cambridge University Press. HOLMES, F. (1987), Scientific Writing and Scientific Discovery. Isis, 78, pp. 220-235. (1989), The Complementality of Teaching and Research in Liebig's Laboratory. Osiris , 5, pp. 121-164, (2nd. series)

JORDAN, K. \& LYNCH, M. (1992), The Sociology of a Genetic Engineering Technique: ritual and rationality in the performance of the plasmid prep, In: CLARKE, A. E. \& FUJMURA, J. H. The Right Tolls for the Job. Princeton: Princeton University Press, pp. 77-114.

KAY, L. (1988), Laboratory Technology and Biological Knowledge: The Tiselius Electrophoresis Apparatus, 1930-1950. History and Philosophy of the Life Sciences, 10, pp. 51-72. . (1989), Selling Pure Science in Wartime: the biochemical genetics of G. W. Beadle. Journal of the History of Biological, 22, pp. 73-101.

KNORR-CETINA, K. (1981), The Manufacture of Knowledge. An essay on the Constructivist and Contextual Nature of Science. Oxford: Pergamon Press.

KOHLER, R. E. (1982), From Medical Chemistry to Biochemistry: the making of a biomedical discipline. Cambridge: Cambridge University Press.

(1991), Drosophila and Evolutionary Genetics: the moral economy of scientific pratice. History of Science, 29, pp. 335-375.

(1991a), Systems of Production: Drosophila, Neurospora and biochemical genetics.

Historical Studies in the Physical and Biological Sciences, 21, pp. 87-127.

KUHN, T. S. (1962), The Structure of Scientific Revolutions. Chicago: University of Chicago Press. 
(1979), Foreword, In: FLECK, L. Genesis and Development of a Scientific Fact. Chicago: University of Chicago Press.(versāo original: FLECK, L. (1935), Entstehung und Entwicklung einer Wisseschlaftlichen Tatsache: einfuhrung in die lehre vom denkskil und denkkollektiv. Basel: Bruno Schwabe.

LATOUR, B. (1987), Science in Action. How to Follow Scientists and Engineers through Society. Cambridge Mass.: Harvard University Press.

\& WOOLGAR, S. (1979), Laboratory Life: the social construction of scientific facts. Londres e Beverly Hills: Sage.

LAW, J. (1966), On the Method of Long Distance Control: Vassels, navigation and the portuguese route to India, In: LAW, J. (ed.), Power Action and Belief. A New Sociology of Knowledge. Londres: Routledge and Kegan Paul.

LEAWIT, J. (1990), Medicine in Context: a review essay on the history of medicine. In: American Historical Review, 95, pp. 1471-1484.

LENOIR, T. (1986), Models and Instruments in the Development of Electrophysiology. Historical Studies in the Physical and Biological Sciences, 17, pp. 1-54.

LIEBENAU, J. (1990), Paul Ehrlich as a Commercial Scientist and Research Administrator. Medical History, 34, pp .65-78.

LOWY, I. (1986), The Epistemology of Science of an Epistemologist of Science: Ludwik Fleck's professional outlook and its relationships to his philosophical works. In: COHEN, R.S. \& SCHNELLE, T. (eds.), Cognition and Fact: materials on Ludwik Fleck. Dordrecht: D.Reidel, pp .421-442.

. (1988), The Scientific Roots of Constructivist Epistemologies: Helène Metzger and Ludwik Fleck. In: Studies on Helène Metzger. (Gad Freudental ed.), Paris: Corpus, pp. 219-235. (1989), Biomedical Research and the Constraints of Medical Practice: James Bumgardner Murphy and the early discovery of the role of lymphocytes in immune reactions Bulletin of the History of Medicine, 63, pp. 356-391.

. (1990), The Polish School of Philosophy of Medicine: from Tytus Chalupinski (18201889) to Ludwik Fleck (1896-1961). Dordrecht: Kluwer.

(1990 a), Variances in Meaning in Discovery Accounts: the case of contemporatry biology. Historical Studies in the Physical and Biological Sciences, 21, pp. 87-121.

(1992), From Guinea Pigs to Man: the Development of HaffKine's Anticholera Vaccine. Journal of the History of Medicine and Allied Science, 47, pp .270-309.

. (1992 a), The Strength of Loose Concepts. Boundary Concepts, Federative Experimental Strategies and Disciplinary Growth: the case of immunology. History of Science, 30, pp. 371-396.

(ed.) (1993), Medicine and Change: innovation continuity and recurrence. Paris e Londres: John Libbey.

(1993 a), Testing for a Sexually-transmissible Discase, 1907-1970: the History of the Wassermann Reaction, In: BERRIDGE, V. \& STAR, P. (eds), AIDS and Contemporary History. Cambridge: Cambridge University Press. (no prelo)

LYNCH, M. (1985), Art and Artefact in Laboratory Science: a study of shop work and shop talk in a research laboratory. Londres: Routledge and Kegan Paul. 
MAULITZ, R. C. (1979), Physician Versus Bacteriologist: the ideology of science in clinical medicine, In: VOGEL, M. J. \& ROSENBERG, C. E. The Therapeutic Revolution: essays in the social history of american medicine. Filadélfia: University of Pensylvania Press, pp. 91-107. MEDAWAR, P. B. (1977), Experiments of Use and Experiments of Light, In: YANN, A. W. (ed.) Beyond tomorrow: trends and prospects in medical science. Nova York: Rockefeller University Press, pp. 20-23.

MITMAN, G. \& FAUSTO-STERLING, A. (1992), Whatever Happened to Planaria? C.M. Child and the Physiology of Inheritance, In: CLARKE, A.E. \& FUJIMURA, J. H. , The Right Tools for the Job. Princeton: Princeton University Press, pp. 287-311.

MORE, J. E. \& MOHR, C.F. (1952), Biologically False Positive Serological Tests for Syphilis. Journal of the American Medical Association, 150, pp. 467-473.

OUDSHOORN, N. (1991), The Making of the Hormonal Body. Tese PHD, University of Amsterdam, datilo.

PICKERING, A. (1984), Constructing Quarks: a sociological history of particle physics. Chicago: University of Chicago Press.

(ed.) (1992) Science as Practice and Culture. Chicago e Londres: The University of Chicago Press, pp. 1-27.

(1992 a), From Science as Knowledge to Science as Practice. In: PICKERING, A.

(ed.) Science as Practice and Culture. Chicago e Londres: The University of Chicago Press, pp. 1-27.

PICKSTONE, J. (ed.) (1992), Medical Innovations in Historical Perspective. Londres: Macmillan.

POLANYI, M. (1958), Personal Knowledge: towards a post-critical philosophy. Chicago: University of Chicago Press.

PORTER, T. M. (1991), Objectivity and Community in Science. Palestra proferida na UCSD, maio. (1992), Objectivity as Standardization: the rhetorics of impersonality in measurment, statistics, and cost-benefit analysis. Annals of Scholarship.

RHEINBERGER, H. J. (1993), From Microsomes to Ribosomes: strategies of representation. Journal of the History of Biology. (no prelo)

(1993a), Sistems of Investigation: medical questions and the quirks of research trajectories. Palestra proferida no worshop Medicina as a Cultural System. Jerusalém, abril.

ROZENKRATZ, B. (1974), Cart Before the Horse: theory, practice and professional image in american public health. Journal of the History of American Medicine, 29, pp. 55-73.

STAR, S. L. (1983), Simplification in Scientific Work: an example from the neurosciences. Social Studies of Science, Londres, 13, 205-228.

. (1989), Regions of Mind: brain research and the quest for scientific certainty. Stanford: Stanford University Press.

\& Griesemer, J. R. (1988), Institutional Ecology, Translations and Boundary Objects: amateurs and profissionals in Berkeleys museum of invertebrate zoology. Social Studies of Science, Londres, $\mathrm{n}^{\circ} 19$, pp. 387-420.

STRAUSS, A. (1982), Social Words and Legitimation Process. Studies in Symbolic Interaction, 4, pp. 171-190. 
STURDY, S. (1992), Political Economy of Scientific Medicine: science, educacion and the transformation of medical practice in sheffield, 1890-1922. Medical History, 36, pp. 125-159.

THOMAS, L. (1988), The Future of Medicine, In: AUSTYN, J. M. (ed.), New Prospects for Medicine. Oxford: Oxford University Press, pp. 114-126.

TRAVEEK, S. (1988), Beamtimes and Lifetimes: the world of high energy physicist. Cambridge Mass.: Harvard University Press.

VOGEL, M. J. \& ROSENBERG, C. E. (eds.) (1979), The Therapeutic Revolution: essays in the social history of american medicine. Filadélfia: University of Pensylvania Press.

VOGELSANG, T. M. (1940), Séro-diagnostic de la Syphilis. Bergen: J. W. Eides Boktrykker.

WARNER, J. H. (1986), The Therapeutic Perspective: medical practice, knowledge and identity in America. Cambridge Mass.: Harvard University Press.

WHITLEY, R. (1984), The Intellectual and Social Organization of the Sciences. Oxford: Claredon Press.

YANN, A. W. (ed.) (1977), Beyond Tomorrow: trends and prospects in medical science. Nova York: Rockefeller University Press. 


\section{Índice Remissivo}

A

ação social - 134, 136, 139, 152, 153, 159 , $163,183,196,197,209,210,212,223$

acumulação - 58, 88, 169, 193, 210, 212, $213,219,223,225,228$

agência humana - 152, 161,173

analítica do poder - 55

anarquismo epistemológico - 116, 117, 124, 128

anomalia - 37, 56, 64, 86, 90-92, 100, 102, $109,130,193,194,196,197,204$, 205,207

anomia - 156, 167

Aristóteles (384-322 a.C.) - 34, 40, 83

arqueologia - 47-49, 53, 54, 56

artefato - 214, 216

autoridade - 81, 108, 112, 139, 191, 194, $202,204,209-212,215,217,228239$

axiológico -65

\section{B}

BACHELARD, Gaston (1884-1962) - 23-25, 29, 138-140, 235

BARNES, Barry - 175, 177-181, 186-187, $189,191-196,203,205,236$

BENTHAM, Jeremy (1748-1832) - 63-64

BERNARD, Claude (1813-1878) - 33, 34, 38, 40

BICHAT, Xavier (1771-1802) - 39, 40

biologia - 23, 24, 26-28, 31, 32, 34-36, 39, $40,50,52,65,68,242,244,248$

biomédico - 235, 236, 240, 241

BLOOR, David - 159, 169, 171, 175, $178-$ $182,185,186,188,190,191,193$, 195-198, 213, 214, 227, 229

BOURDIEU, Pierre - 133, 134, 138-142, $146-150,152,167,171,199,200$, 208-213, 215-220, 222, 223, 228-230

BOWKER, Geof - 213

BROUSSAIS, François Joseph Victor (1772. 1831) - 33, 34, 40

BROWN, Robert (1773-1858) - 33

BUFFON, Georges-Louis Leclerc (17071788) - 25-27, 34

\section{C}

campo científico - 73, 139, 140, 145, 148, $201,208-213,227,228,242$

campo social - 139, 149

CANGUILHEM, Georges - 23-41

capital simbólico - 167, 171, 209, 210, 212, $224,225,228$

capitalismo comunitário - 225

carreira científica - 148

ciclo de credibilidade - 171, 217-221, 227, 229

ciência normal - 76, 81-95, 162, 167, 194, 202-207, 213, 228

cientificidade - $26,45,46,51,68,70,72$, $74,76-77,79,81,88,96,105,106$, $133,139,157$

classificaçăo - 62, 190, 236, 242

clínica - 32, 39, 44, 52, 65, 245-247

cognição - 151, 170, 176, 180-183, 186

COLLINS, Randall - 170, 230, 231

competência científica - 209, 210, 212

competição por prioridade - 155, 168

COMTE, Augusto (1798-1857) - 26

comunicação - 72, 82, 101, 147, 189-192, $195,202,204,207$

conceito - 24, 26, 28-38, 40, 58, 59, 65, 95, $119,136-138,152,156,160,162$, $171,185,187-189,191-195,201,208$, $209,217,225,237,246$

condição de possibilidade - 28, 29, 32, 35, 69,81

conflito $-73,80,92,95,153,157,158,164$, $200,206,209,212,222,227,228$

conhecimento - 23, 25-26, 28, 31-39, 45, $49,51,55,56,70-74,87,91,93,97$, $99,100,103-106,108,109,112,113$, $115,119,121,123,124,128,130$, 133-140, 142, 144, 145, 147-149, 151, $153,155,157-163,166-173,175-183$, 185-187, 190-196, 198 - 199, 201, 204, 206-209, 211, 213-216, 221-228, $231,233-237,240-241,247$

conotação - 246, 248 
consenso - 71-72, 75, 78-81, 83, 85, 97, 99, $147,173,178,189,182,199,202-$ $204,208,212,215,228,233,241$

construção - 25, 27-29, 32, 63, 103, 107, $128,133,139-141,146,151,161,168$ - 169, 172 - 173, 194, 197, 200, 214 $216,234,237,240$

construtivismo - 231

contexto de descoberta - 121, 124

contexto de justificação - 121, 124

contingente - 151, 173, 189, 192, 221-223, 234

continuidade - 23-25, 27, 31, 94, 153, 159, $176,192,206,210,241,243$

contra-exemplo - 85-87, 89, 97, 110, 194

conversão - 71 - 72, 99, 101, 206, 207, 217 $220,227,229$

correlações de força - 53, 60, 61

corte epistemológico -

cosmovisão - 122

crédito científico - 171, 209, 210, 212

crença - 29, 82, 93, 137, 152, 157, 158, $162,163,166,169,170,173,179$, $191,195,212,217,238$

crise $-72,75,84-88,90,92-95,102,194$, 205, 207

critério de cientificidade $-74,77,106$

cultural - 115, 133, 142, 144, 146-148, 154 $156,163,184,192,202,233$,

\section{D}

DARWIN, Charles (1809-1882) - 34

democratização - 144, 145

DESCARTES, René (1596-1650) - 24, 29-31, 34,40

descoberta - 31, 40, 50, 69, 70, 72, 90, 94, $98,106,107,109,121,124,137,138$, $145,166-168,177,182-184,194,211$, $236,243,246$

descontinuidade - 24, 25, 27-29, 35, 83, 94, $95,98,99,179$

dialética - 129

dicotomia - 28, 38

difusão - 47, 141, 146, 233, 235, 239-244, 247

disciplinar - 54, 61-64, 83, 86, 89, 91, 95, 98,137

discursiva - 25-29, 31, 32, 45, 48, 50, 54 discurso - 26, 27, 33, 41, 44, 45, 48-52, 54, $55-59,67,71,72,84,101,144,147$, $164,173,179,195,209$

dispositivo - 50, 53, 56, 58, 60, 63

documento $-49,50,53$

doença - 32-34, 37, 39 - 41, 43, 54, 59, 62, $63,190,235-237,240,245,246,249$

DUHEM, Pierre (1861-1916) - 105, 194

DURKHEIM, Emile (1858-1917) - 154-156, $158,159,172,176,178,179,186$

E

economia de conversāo - 227

economia de troca - 227

educação profissional - 84

EINSTEIN, Albert (1879-1955) - 73, 99

empirismo lógico - 80, 87, 105

empresa - 163

enunciado - 18, 49, 51, 53, 54, 105, 106, $116,127,134,138,160$

epistemologia - 23, 24, 26, 27, 31, 32, 67$72,74,87,101,102,104,117,138$, $139,161,199,236$

epistemológico - 24, 28, 31, 35, 36, 57, 67, $69,71,72,92,93,96,101,103,115$, $117,124,127,131,186,214,229,236$

erro $-32,33,37-39,41,46,49,53,58,136$, $138,139,180,197,207$

Escola de Edimburgo - 159, 169, 175, 176, $178,180,181,184,185$

escolástica - 144

esoterização - 144, 145, 147

estabilização - 227, 234, 235, 240, 241, 244,247

estilo de pensamento - 135, 145, 146, 237 , $238,240,241,243,247-249$

estratégia - 45, 53, 55, 57, 59, 64, 107, 116, $124,193-197,210-218,220,244$

estratégico - 55, 61

estrutura social - 135, 146, 154, 156, 161 , $162,166,172,213,226,228$

ethos científico - 154, 163, 167, 169

ética - 47, 164, 211

exemplares- 82, 83, 188, 205

experimentação - 27, 79, 162, 192 
F

falseacionismo ingênuo - 106

falseamento - 105-107, 114, 118, 119, 130

falsificacionismo $69,71,74,87$

fato científico - 139, 168, 236, 237, 239, 240

FEYERABEND, Paul (1924-1994) - 103, 104, $107,109-130,231$

filiações - 24, 25, 27, 34, 47

filosofia - 26, 32, 38, 39, 43-46, 47, 48, 57, 58, $64,67,68,71,72,74,78,80,94,96$, $103,104,109,112,114,125,177,182$, $199,234,236$

financiamento - 217, 220, 226, 228

finitismo - 186, 189, 192, 193, 195

física - 36, 39, 40, 57, 67, 68, 70, 81, 83, $91,94,99,117,154,155,161,240$

físico-química - 23, 31, 242

fisiologia - 28-30, 34, 38-40, 244

FLECK, Ludwick (1896/1961) - 190, 235 $240,247,248$

força - 31-32, 51, 60, 61, 70, 73, 75-77, 85, $86,88,90,95,97,98,100,104,107$, $111,114-116,120,130,138,171$, $178,190,193$

formação discursiva - 31, 49, 50

formas de vida - 124, 186, 188, 190, 193, 195-197

FOUCAULT, Michel (1926-1984) - 39, 43 - 65

funcionalismo - 75, 94, 155-156

G

GALENO, Claudio (130-201) - 30

GALILEI, Galileu (1564-1642) - 40, 112, 118

genealogia - 23, 27, 47, 53, 56, 59,

gênese - 33, 46, 73, 142, 160, 202, 203, $235-237,239$

genética - 37, 243-244

geração espontânea - 33

GIERYN, Thomas F. - 151, 169, 170, 231

governo - 221, 228

\section{$\mathrm{H}$}

heurística - 25, 39, 84, 107, 110

HIPÓCRATES (460-377 a.C.) - 34 história arqueológica - 46, 49, 52

história da medicina - 233

história das ciências - 23, 24, 31, 32, 36, 41, $45,103,106,114,121,124$

história do saber - 43

história genealógica - 53-56, 58

história normativa - 23

historiografia - 233, 235, 236, 240, 246

homem econômico - 171, 223, 224

I

identidade - 33-34, 38, 40, 68, 93, 150, $152,159,221$

ideologia científica - 23, 32-36, 38

iluminismo - 135

ilusão epistemológica - 118, 119

incomensurabilidade - 101, 118, 119, 123, $127,132,169,231,238$

indivíduo - 26, 61, 62

indústria - 147 - 148, 221, 229, 241, 143, 241, 243,244

INFELD, Henrik - 73

informação - 37-39, 41, 110, 112, 141, 183, 218 - 219, 223, 225, 229, 244

instituição - 52, 64, 140, 154, 163, 169, $171,172,210,221$

interdependência - 162, 163, 165, 218

interesse $-32,36,39,45,70,77,101,154$, 157 - 158, 161, 165, 169, 172, 185, $194,195,198,210,211,218$ - 219, $221,227,233-234,236,240,242,249$

internalismo - 225, 227

invenção - 38, 92, 94, 105, 107

investimento - 210, 216 - 219, 225, 229

irracionalismo - 117, 124, 127

J

jogos de linguagem - 176, $185-190,192$ $193,195-196$

jogos de verdade $-43,54$

juízo - 23, 79, 112, 131, 139, 157, 189, 194

justificacionismo - 87,105 
K

KANT, Immanuel (1724 - 1804) - 103, 112

KNORR-CETINA, Karin - 137, 152, 17 1- 172, $175,185,199-200,214,220-230$, 234,240

KUHN, Thomas - $67-102,107,109-113$, $118-119,127,152,162,167,169-$ $170,179,181,186-187,193-194$, 199 - 208, $210-213,218,220,222$, $227-230,236$

L

laboratório - 33, 172, 182 - 183, 198, 214 $218,220-231,233-237,239-249$

LAKATOS, Imre (1922 - 1974) - 74, 87, 97, 103 $-121,123-124,126,128-131,181$

LATOUR, Bruno - 152, 167 - 168, 171 $173,175,199-200,211,214-223$, $227-230,234,240,247$

linguagem - 44, 54, 73, 79, 95, 118 - 119, $147,176,185-197,204,216,231$

lucro -210

\section{M}

macrossociologia - 230 - 231

MACENDIE, François (1783 - 1855) - 33 - 34 MANNHEIM, Karl (1893 - 1947) - 133 - 140, 142 - 146, 150, 153 - 155, 157 - 161, $172,176,178-179,186$

MASTERMAN, Margareth - 76

matrizes disciplinares - 82

MAUPERTUIS, Pierre Louis Moreau de (1698-1759) - 34

mecanicismo - 33

mecanicista - 25, 26

mercado - 146 - 147, 152 - 153, 167, 171, 199 - 201, 208 - 211, 213, 215 - 216, 219 $221,223-225,228-231,242,247$

mérito - 211, 217

MERTON, Robert - 134 - 135, 151 - 173, 231 método - 23 - 25, 38, 40, 46 - 47, 52 - 53, $67-68,77,79-80,87,96,105,112$, $114-115,118,123,124,127,137$, $165,179,181,237-239,245$ método antropológico - 127

metodologia - 31, 65, 75, 79 - 80, 104, 106, $108-111,116,118,120-125,131,181$

microbiologia - 241

microssociologia - 230

mito $-28,32-33,55,73,115,122$

modelo - 33, 41, 54, 63, 72, 82, 94, 97, $104,129,136,144,152,164,181$ $182,193,197,216-217,219-220$, $223-225$

monopólio - 142, 144, 177, 202, 209, 218, 231

MORGAN, Thomas Hunt (1866 - 1945) 242 - 243

MORICK, Harold - 99

mundo social - 140 - 141, 209, 235

$\mathrm{N}$

NIETZSCHE, Friederich (1844 - 1900) - 37 - 38 norma - 36, 40, 62, 166 normalização $-43,54,64$ normativa - 23, 39, 41, 112, 213

0

OKEN, Lorenz (1779 - 1851) - 25 - 27

olhar - 43, 63, 99, 214

ontologia - 33, 40, 105, 117

$\mathrm{P}$

padronização - 234, 239, 241 - 242, 246, 247 panopticon -63

PARACELSO, Theophrastus, (1493 - 1541) - 40 paradigma - 71 - 72, 74, 76 - 101, 158, 170, 175, 193, $201-208,212,215-216$, 228

PARSONS, Talcott - 154 - 156

passado atual $-24,28,30$

patente $-69,178,229$

patológico - 24, 33, 36 - 38, 40, 238

pesquisa extraordinária - 75, $88-89,94$

poder - 29, 33, 37 - 38, 41, 43, $45-48,51$ $65,68,75-76,78-80,87,96-98$, $101,108,123-124,147-148,150$, $195,208-211,217,222$ 
política - 43, 45, $50-51,55-58,63,65$, $78,95-96,107,146-147,167,172$, $210,216,224,233$

POPPER, Karl - $69-70,72-73,77,79-80$, $84-90,98,105-107,109-110,114$, $117,124,229$

positividade $-26,32,45,48,51,58,61,138$ positivismo - 37, 135

prática discursiva - 48, 50

prática(s) - 233

pré-científico $-25-27,46$

precursor - 25

problematização - 48, 54, 75, 87

produção de verdade - $46-47,51,55,57$

produtividade tática - 53

produto - 61, 148, 163, 173, 179, 210 $211,213-214,221-223,228-229$, $236,239,345,247$

programa de pesquisa - 108, 121, 129, 242

programa forte - 169, $175-176,178-186$, $193,198,213-214$

progresso - 35, 46, 74, 80, 85, 117, 177, 206 $-209,211,213,219,228,246,249$

propriedade intelectual - $166-167,229$

prova - 32, 35, 44, 89, 95, $104-106,108$, 114,124

psicologismo - 23, 27

puzzles - 86, 88, 92

\section{Q}

questão - $26,31,34,36$ - 38, 40, 45 - 46, 48, 51, $53,56-57,59,61,64,68-69,71,81,86$, $90,99,106,112-113,115,118-119,122$ $-128,130-131,133,135-137,139,142-$ $143,152,160,170,172,184,187-188$, 190, 194, $202-203,206-207,209,211$, $213,217,219-220,226,229-231,246$ química - $33-34,36,57,68,70,83,233$, 243,245

\section{$\mathbf{R}$}

racionalidade - 24, 39, 45, 47, $67-71,91$, $94,96-98,102-104,106,108-111$, $113-116,119-125,127-131,138$, $141,153,182-183,186,193,222$ racionalismo - 39, 72, $104-105,113-114$, $116-118,120-125,127-128,130,164$ RADNITZKY, Gerard - 95

RANK, Otto (1884 - 1939) - 33

razão $-23,25,37,39-41,45,51,60,65$, $71,74,79,84,94-95,100,102-103$, $109-110,112,114,117,121-123$, $125-130,133,135-136,138,140$, $153,198-200,213,224,228$

reconstrução racional - 103, 109, 112, 181

recorrência - $26-28,30-31,34$

reflexividade $-213-214$

regras - $45,47-49,53-54,56-57,65,73$, $77,87,92-95,98,101,106-107$, $111-112,114,116-118,120,122$ $124,126,128-130,146-147,179$, $183,190,202,210-211,222$

relacionismo $-136,160$

relativismo - 47, 135, $160-161,169-170,231$ representação - 35, 47, 53 - 54, 61, 87, 141, $167,178,185,209,227$

resistência - 29, $60-63,93,207$

retificação - 38

reversão gestáltica - 94 - 95, 99, 101

revolução científica - 91, 93, 95, 100, 194, $205-207,212-213$

$\mathrm{S}$

saber - $24-30,32-39,43-53,56-59,63$ $-65,68,70,73,80,82,104,112,133$, $144,148,170,188,216,240$

secularização - 144

senso comum - $51,111,117,120,144,158$, 192, 198

SHAPERE, Dudley - 76

socialização - 64, 143, 146, 149, 166 - 168, $191,203-204,223,238$

sociologia - 26, 57, 68 - 69, 72, 80, 101, 133 $142,149,152-155,157-163,166,168$ $-173,175=183,185-186,193,198$ $199,213-214,222-223,229-231,234$

STAHL, Georg (1660 - 1734) - 34, 40

subjetividade $-110,122,198$

sujeito - $38,55-56,94,122,124,130$ $131,136,149,211$

supervalorização - 24, 32 - 33, 35 - 38

SUPPE, Frederick - 78 
$\mathrm{T}$

técnica - 23 - 24, 34, 36, 38 - 39, 41, 50, 59, $64,195,209,233,242,247$

teoria - $23-31,33,36,46,70-75,78-81$,

$84-92,94,96-101,105,107-109$,

$112-121,124-127,136-137,145$,

$153,155,160,163,172-173,175-$

$176,179-180,184-187,189,191$ -

$196,205,238,240$

teórica - 25 - 26, 35, 37, 39, 52, 57, 68, 75, $107,134-135,139,155,167,175$,

$177,191-192,194,197,236$

testes críticos - 105, 119

totalidade - 26 - 27, 32, 78, 234

TOULMIN, Stephen - 99

tradição científica - 205

tradução - 23, 101, 119, 126 - 128, 196, $201,206,226,230-231,233,240$, $243-244,246$

transcientífica - 226

transepistêmica - 201, 221, 226 - 228

treinamento - 143, 187, $191-192,194,202$ $-203,205,216$

V

valor - $29-30,36,38,41,47,79,84,90$, $92,101-102,108,112,152,157$. $158,162-164,166-168,170,173$, $197,211,219,229$ verdade $-28,31-32,38-39,43-47,49-51$, 53 - 59, 62, 65, 74, 84, 90, 97, 105, 110, $113,115,122-123,125,130-131,135$ $-137,160,163,166,170,181,202,238$ verificacionismo - $69-70,74$ vida - $23-27,31-41,46,51-54,57-58$, $62-64,83,95-96,115-116,120,123$ - 124, 140, 142, $145-147,157,159$, $167,173,178,186-190,192-193$, $196-197,203,210,215,222,235$ visão de mundo - $78-79,81,83,86,95,99$ vitalismo - $23,26,31,36,40$

\section{W}

WASSERMAN, August Von (1866 - 1925) WEBER, Max (1864 - 1920) - 134, 141 $142,152-153,155,157,159,164$, 166,173

WHYTT - 30

WILLIS, Thomas (1621 - 1675) - 29 - 31

WITTGENSTEIN, Ludwig (1889 - 1951) - 95, 176, 179, $185-191,193-194,196$

WOOLGAR, Steve - 200, 214 - 220, 222 $223,228-230,234,240$

Rio de Janeiro, novembro de 2002.

$2^{\mathbf{a}}$ reimpressão e acabamento:

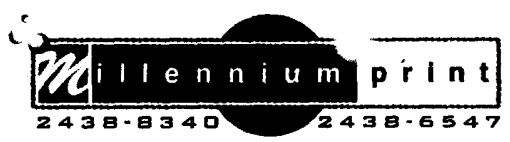

